\title{
Oil and Gas Resources of the West Siberian Basin, Russia
}

December 1997

\section{Energy Information Administration \\ Office of Oil and Gas}

U. S. Department of Energy

Washington, DC 20585

This report was prepared by the Energy Information Administration, the independent statistical and analytical agency within the U.S. Department of Energy. The information contained herein should be attributed to the Energy Information Administration and should not be construed as advocating or reflecting any policy of the Department of Energy or any other organization. 


\section{DISCLAIMIER}

Portions of this docament misy be illegible in electronic image products. Images are produced from the best arailable original doesoment 


\section{Preface}

Oil and Gas Resources of the West Siberian Basin, Russia is part of the Energy Information Administration's (EIA's) Foreign Energy Supply Assessment Program (FESAP). The primary objective of this study is to assess the oil and gas potential of the West Siberian Basin of Russia. The study does not analyze the costs or technology necessary to achieve the estimates of the ultimate recoverable oil and gas.

This is the second report on an oil and gas province in the former Soviet Union. The first, Oil and Gas Resources of the Fergana Basin (Uzbekistan, Tadzhikistan, and Kyrgyzstan), was published in January 1995.

Russia's West Siberian Basin contains sufficient oil and natural gas to affect world petroleum markets. The basin supplies approximately 70 percent of the oil and 90 percent of the gas production for Russia. Decreases in produced volumes from the basin would require that the demand for petroleum in Russia be met from other sources. Likewise, increases in production would increase the amount of oil or gas for export into international markets.

This study uses reservoir data to estimate recoverable oil and gas quantities which were aggregated to the field level. Field totals were summed to a basin total for discovered fields. An estimate of undiscovered oil and gas, from work of the United States Geological Survey (USGS), was added to give a total basin resource volume. Recent production decline points out Russia's need to continue development of its discovered recoverable oil and gas. Continued exploration is required to discover additional oil and gas that remains undiscovered in the basin.
The estimates of recoverable oil and gas for the regions of the basin, the individual fields, and the geologic intervals are intended as a guide to organizations such as oil and gas operating companies, financial institutions, and government agencies. In addition to the estimates of maximum recovery, the reported and estimated reservoir parameters are a valuable reference source. The appendices contain the estimates of ultimate recovery by field and frequency distributions of the reservoir data. Additionally, a computer diskette contains the reported and estimated parameters for each productive reservoir.

Several independent petroleum engineers and geologists with experience in West Siberia have reviewed the analysis and contributed many useful suggestions which have been incorporated in the report. Retired and current staff of the USGS also assisted in reviewing this report. The assistance of all of these professionals is gratefully acknowledged. Special thanks is given to Dr. James W. Clarke and Dr. James A. Peterson, USGS retired, who contributed Appendix A, Petroleum Geology in its entirety.

Publication of this report is in keeping with responsibilities given the Energy Information Administration (EIA) in Public Law 95-91/Section 205(a) and Section 657(2)a for estimating foreign energy supply information. General information about this publication may be obtained from Joan Heinkel, Director of the Reserves and Natural Gas Division, (202) 586-6090, or John Wood, Director of the Dallas Field Office, (214) 720-6150. Specific information regarding the content or preparation of this report may be obtained from Floyd Wiesepape, (214) 720-6166, fax (214) 720-6155, or E-mail fwiesepa@eia.doe.gov.

\section{Diskette Information}

Reservoir-level data are available in a self-expanding, compressed file on a 3.5-inch diameter diskette. The diskette also contains a text file describing the data file and instructions for opening the data file. The data file expands into an EXCEL spreadsheet XLS file. The data encompass estimated and reported reservoir parameters and resulting volumetric analyses of oil and gas. The file contains data for 10 regions plus data for fields of unknown location in the West Siberian Basin. 



\section{Contents}

Page

Executive Summary $\quad \ldots \ldots \ldots \ldots \ldots \ldots \ldots \ldots \ldots \ldots \ldots \ldots \ldots \ldots \ldots \ldots \ldots \ldots \ldots \ldots \ldots \ldots, \quad$ ix

1. Overview of the West Siberian Basin $\ldots \ldots \ldots \ldots \ldots \ldots \ldots \ldots \ldots \ldots \ldots \ldots \ldots \ldots \ldots \ldots \ldots \ldots \ldots \ldots \ldots \ldots$

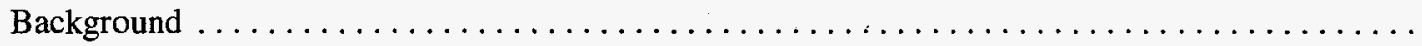

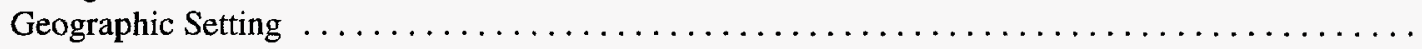

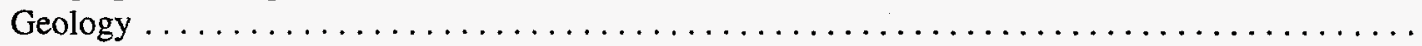

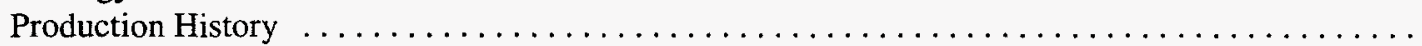

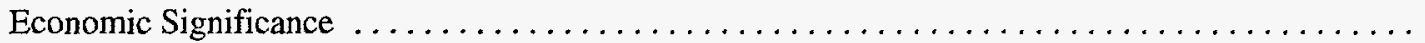

Largest Fields

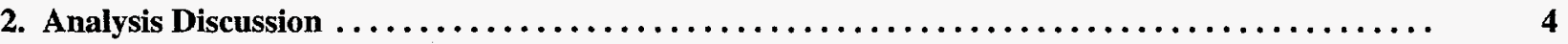

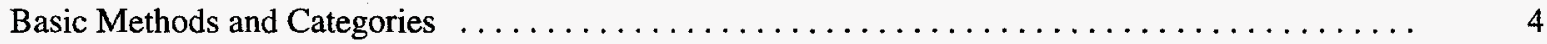

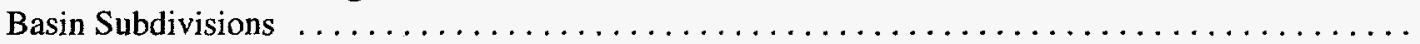

Production by Area $\quad \ldots \ldots \ldots \ldots \ldots \ldots \ldots \ldots \ldots \ldots \ldots \ldots \ldots \ldots \ldots \ldots \ldots$

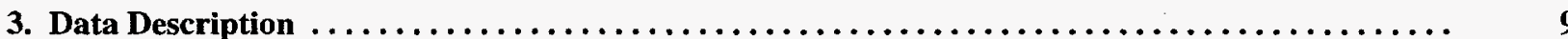

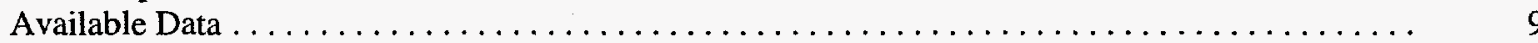

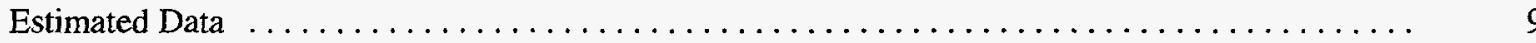

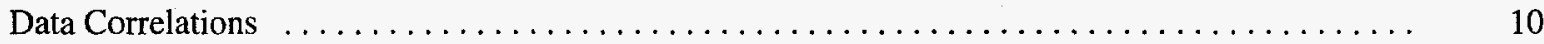

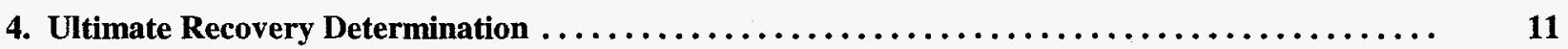

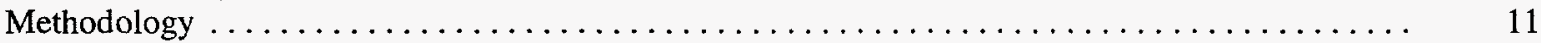

Oil Reserves $\ldots \ldots \ldots \ldots \ldots \ldots \ldots \ldots \ldots \ldots \ldots \ldots \ldots \ldots \ldots \ldots \ldots \ldots \ldots \ldots \ldots \ldots \ldots \ldots \ldots \ldots \ldots \ldots$

Primary Recovery $\ldots \ldots \ldots \ldots \ldots \ldots \ldots \ldots \ldots \ldots \ldots \ldots \ldots \ldots \ldots \ldots \ldots \ldots \ldots \ldots \ldots$

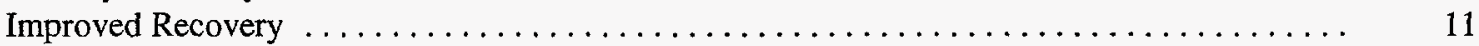

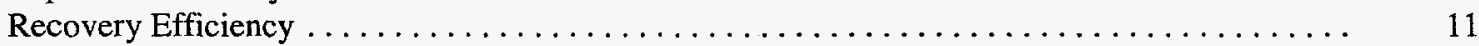

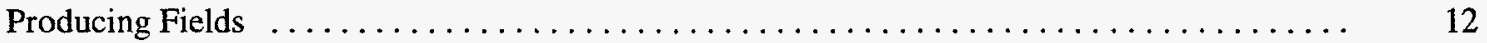

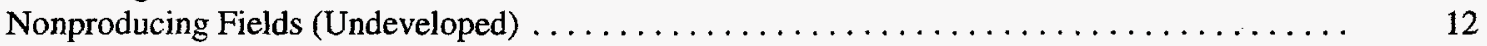

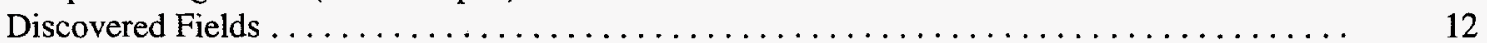

Undiscovered Resources $\ldots \ldots \ldots \ldots \ldots \ldots \ldots \ldots \ldots \ldots \ldots \ldots \ldots \ldots \ldots \ldots \ldots \ldots \ldots \ldots \ldots \ldots \ldots \ldots$

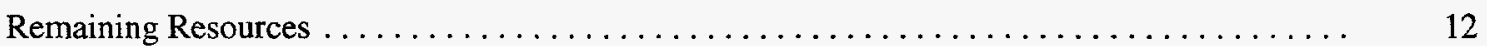

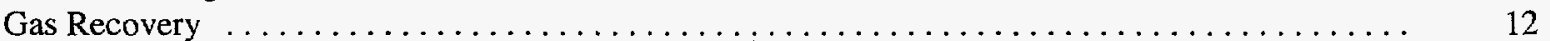

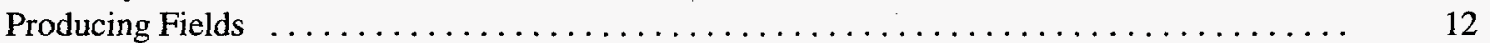

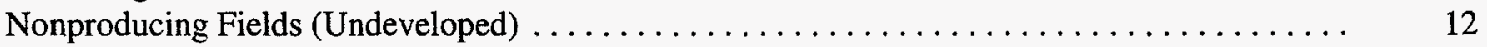

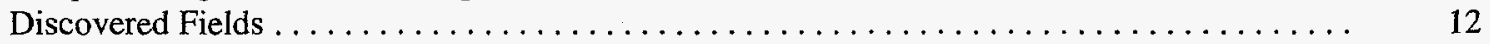

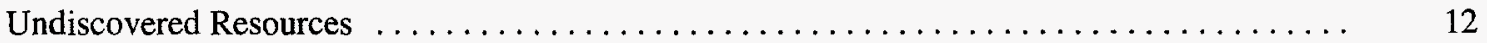

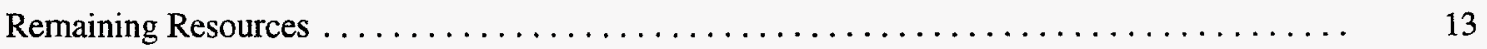

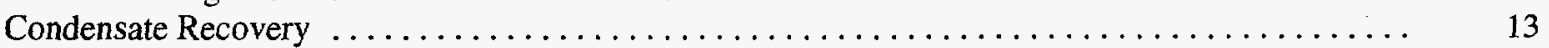

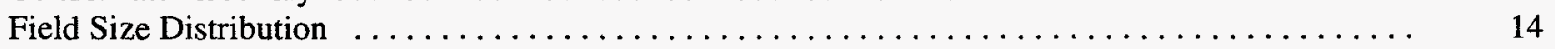

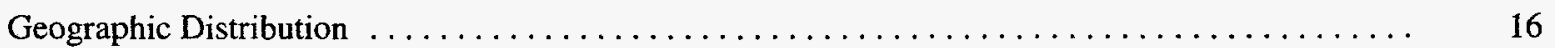

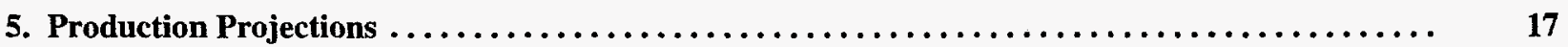

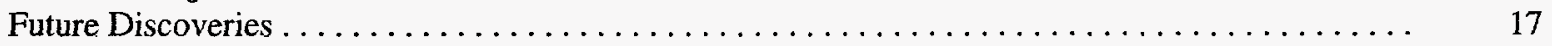

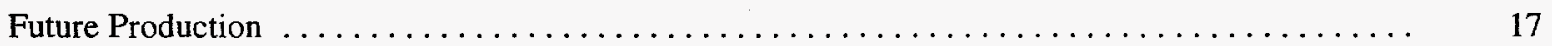

Oil and Condensate $\ldots \ldots \ldots \ldots \ldots \ldots \ldots \ldots \ldots \ldots \ldots \ldots \ldots \ldots \ldots \ldots \ldots \ldots \ldots \ldots \ldots \ldots \ldots \ldots$

Gas $\ldots \ldots \ldots \ldots \ldots \ldots \ldots \ldots \ldots \ldots \ldots \ldots \ldots \ldots \ldots \ldots \ldots \ldots \ldots \ldots \ldots \ldots \ldots \ldots \ldots \ldots . . \ldots 21$

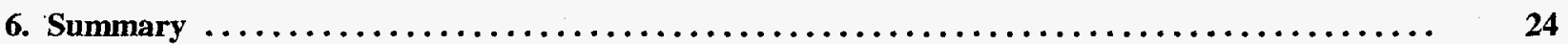


Appendices

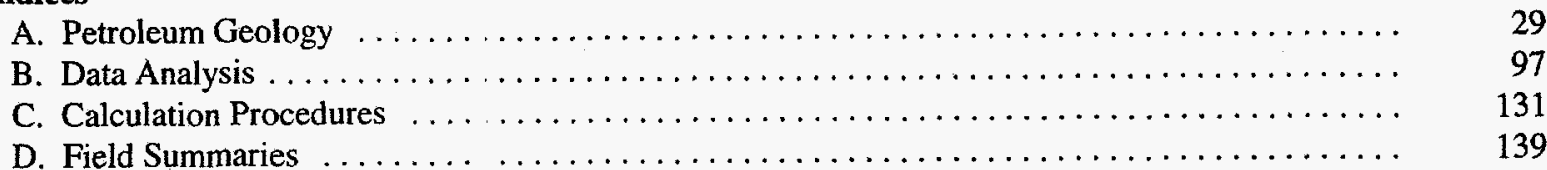

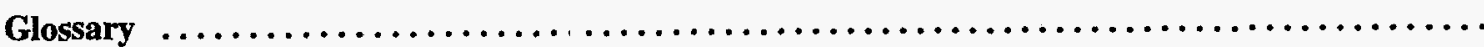


Tables

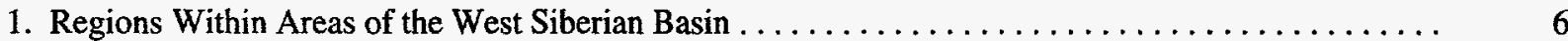

2. Geologic Units Combined Within Productive Areas of the West Siberian Basin for Data Analysis ～. $\quad 6$

3. Stratigraphic Chart Linking Geologic Age with Pay Zone Identifiers, by Area and Region, West

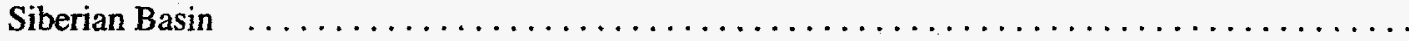

4. Percentage of Reservoirs with Data Available within Major Geologic Intervals of the West Siberian Basin

5. Average Reservoir Recovery by Regions of the West Siberian Basin as a Percent of Original Oil

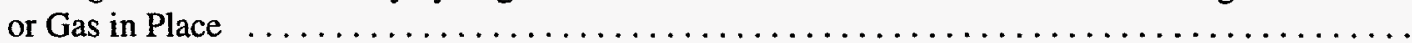

6. Estimated Oil and Condensate Resources in the West Siberian Basin, End of 1994 . . . . . . . . . .

7. Estimated Natural Gas Resources in the West Siberian Basin, End of $1993 \ldots \ldots \ldots \ldots \ldots \ldots$

8. Discovered Oil and Gas by Region and Area, West Siberian Basin

\section{Figures}

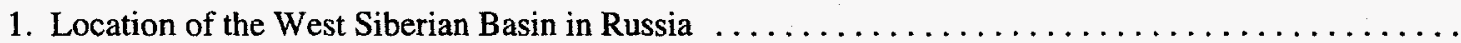

2. Map of the Oil and Gas Regions of the West Siberian Basin $\ldots \ldots \ldots \ldots \ldots \ldots \ldots \ldots \ldots \ldots$

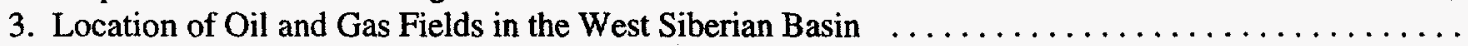

4. Crude Oil Field Size Distribution for Discovered Fields, West Siberian Basin $\ldots \ldots \ldots \ldots \ldots \ldots$

5. Gas Field Size Distribution for Discovered Fields, West Siberian Basin $\ldots \ldots \ldots \ldots \ldots \ldots \ldots$

6. Cumulative Discovered Crude Oil, West Siberian Basin . . . . . . . . . . . . . . . . . .

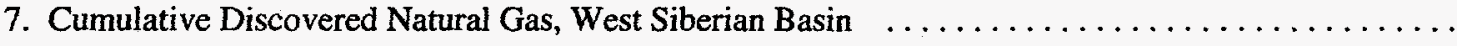

8. Ultimate Oil and Condensate Discoveries and Theoretical Production, West Siberian Basin ......

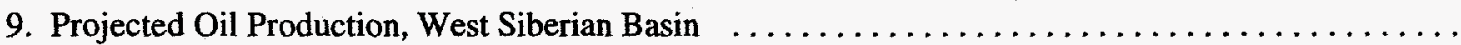

10. Projected Cumulative Oil and Condensate Production, West Siberian Basin $\ldots \ldots \ldots \ldots \ldots \ldots \ldots$

11. Ultimate Gas Discoveries and Theoretical Production, West Siberian Basin $\ldots \ldots \ldots \ldots \ldots \ldots$

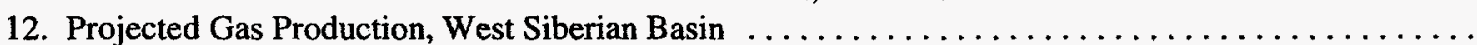

13. Projected Gas Cumulative Production, West Siberian Basin 



\section{Executive Summary}

This analysis, prepared in cooperation with the U.S. Geological Survey (USGS), is part of the Energy Information Administration's (EIA's) Foreign Energy Supply Assessment Program (FESAP). The purpose of the program is to review the potential of major oil and gas provinces around the world. This report aggregates calculated reservoir-level results to field and then to basin level. The production projections establish a possible range of potential.

By area and resources, the West Siberian Basin is the largest oil and gas producing province in the Russian Federation of the former Soviet Union. Approximately 70 percent of the oil and 90 percent of the gas produced in Russia come from the West Siberian Basin. Petroleum consumption in Russia in 1995 of approximately 1.07 billion barrels of oil and 14.5 trillion cubic feet of natural gas was exceeded by production from the basin of approximately 1.5 billion barrels and 21 trillion cubic feet per year. The United States consumption of petroleum in 1995 was 6.5 billion barrels with production of 2.4 billion barrels of oil and 18.8 trillion cubic feet of gas. Production from the basin supplies Russia, other parts of the former Soviet Union, and Europe as well as other parts of the world. World supplies would have to be redirected to maintain a balance of supply if oil and gas production were not available from the basin.

Discoveries in the basin total 634 oil fields and 147 gas fields. Individual reservoir data are available in 70 percent of the fields. The data represents over 1500 reservoirs or approximately three productive reservoirs per field that has data reported. The decline of oil production from the producing fields from 3.1 to 1.5 billion barrels per year ( 8.5 to 4.1 million barrels per day) between 1988 and 1994 and a slight decline from 22.6 to 21.9 trillion cubic feet per year (61.9 to 60.0 billion cubic feet per day) of gas between 1991 and 1993 cause concern about the potential of the basin as a long term supplier of oil and gas. However, the sum of the estimated ultimate recovery (EUR) from discovered fields by EIA and undiscovered resources estimated by the USGS indicate that significant potential remains in the West Siberian Basin (Table ES1).

Remaining oil and condensate EUR are 65.5 billion barrels. Remaining EUR of undeveloped fields and undiscovered resources of oil and condensate total
101.4 billion barrels. Production projections for oil based on maintaining the current rate or returning to the previous peak producing rate indicate that sufficient oil volume exists to maintain those rates for 35 to 50 years. Recent production decline and maximum estimates of ultimate recovery cause this producing time to be optimistic and longer than the production time estimated for gas. However, to accomplish this ultimate recovery requires significant development of new fields, continued maintenance and development of producing fields, and the application of advanced technology. Continued development will require significant amounts of money and technology advancements. Economic factors are not included in this analysis.

The potential also exists for significant natural gas production. The EUR of developed reserves are 551 trillion cubic feet with 341 trillion cubic feet in undeveloped fields. Undiscovered resources are 1084 trillion cubic feet. The development of the remaining potential could arrest the current decline and maintain production at the current rate for another 32 years. The length of time that the peak rate could be maintained is less than the estimates of time that a peak oil rate could be maintained because the recent gas rate decline has not been as severe as the decline of the oil rate. The gas producing fields are located in the northern portion of the basin, north of the Arctic Circle, and additional development potential exists offshore in the Kara Sea. High development costs and logistical problems can be expected to delay the development of some of the possible and undiscovered gas resources.

Significant condensate production potential exists in the basin. Ultimate recovery was estimated where data were available. Five billion barrels of discovered condensate and four billion barrels in the undiscovered category represent a minimum potential for the basin and are reported as a portion of the EUR. Condensate production was not separated from crude oil production.

The analysis of the oil and gas resources of the West Siberian basin provides a view of the potential of a major resource in Russia which has global implications in a world economy. The included basic data also provide a source of information for additional study in more detail for areas, fields or geologic intervals of interest. 
Table ES1. Estimated Crude Oil, Ccindensate, and Natural Gas Resources of the West Siberian Basin, as of Year End 1994 (OII) and 1993 (Gas)

\begin{tabular}{lcc}
\hline Resource Description & $\begin{array}{c}\text { Oil and Condensate } \\
\text { Billion Barrels }\end{array}$ & $\begin{array}{c}\text { Natural Gas } \\
\text { Trillion Cubic Feet }\end{array}$ \\
\hline $\begin{array}{l}\text { Cumulative Production } \\
\text { Developed Fields } \\
\quad \text { Remaining Estimated Ultimate Recovery }\end{array}$ & 49.3 & 214 \\
$\begin{array}{c}\text { Discovered Undeveloped Fields } \\
\text { Estimated Ultimate Recovery }\end{array}$ & 65.8 & 551 \\
$\begin{array}{c}\text { Undiscovered Resources } \\
\text { (USGS, Mean Value) }\end{array}$ & 51.0 & 341 \\
Basin Total Resources & 50.4 & 1084 \\
\hline
\end{tabular}

Source: Energy Information Administration, Crfice of Oil and Gas. 


\section{Overview of the West Siberian Basin}

\section{Background}

The Energy Information Administration (EIA) in cooperation with the U. S. Geological Survey (USGS), has assessed the resources, reserves, and production potential of 14 major oil and gas producing regions outside the United States. This series of assessments was done under EIA's Foreign Energy Supply Assessment Program (FESAP). The basic approach used is to combine historical drilling, discovery, and production data with EIA estimates of ultimate recovery and USGS generated undiscovered resource estimates. Field-level data for discovered oil and gas were used for the previous assessments. Supply projections through depletion were typically formulated for the country or major producing region.

EIA has prepared an assessment of oil and gas resources of one province in the former Soviet Union (FSU). A report on the oil and gas resources of the Fergana Basin ${ }^{1}$ in the republics of Uzbekistan, Tajikistan, and Kyrgyzstan was published in January 1995.

\section{Geographic Setting}

In terms of the geographic area and recoverable oil and gas, the largest oil and gas producing province in the FSU is the West Siberian Basin in the Russian Federation (Russia). Not only is it the largest in the FSU but it also is one of the largest in the world, from about $52^{\circ}$ $\mathrm{N}$. to $73^{\circ} \mathrm{N}$. latitude and about ${ }^{\circ} 60 \mathrm{E}$. to $90 \mathrm{E}$. longitude (Figure 1). The basin covers an area of approximately 1.3 million square miles, more than twice the size of the entire state of Alaska. The basin extends eastward from the Ural Mountains to the Yenisey River and northward from the Kazakh Uplands and the Altai and Sayan Mountains into the Kara Sea, a distance of roughly 1,500 miles. A comparison of similar latitudes to North America would place the West Siberian basin from Vancouver Island (off the northwest coast of the state of Washington) north to latitudes in the Beaufort Sea, off northern Alaska.
Topographically, the basin forms a nearly perfect plain, with an imperceptible slope to the north. This is the world's largest area of unbroken flat terrain. It is characterized by waterlogged soils, shallow lakes, and extensive swamps. Winters last seven to nine months with mean temperatures ranging from about $+5^{\circ}$ to $-20^{\circ}$ F (degrees Fahrenheit).

\section{Geology}

Structurally, the West Siberian Basin is a broad, relatively gentle downwarp filled with 10,000 to 33,000 feet of post-Paleozoic marine, near shore marine, and continental clastic sedimentary rocks. The underlying basement is composed of Precambrian and Paleozoic fold systems with large areas of partly metamorphosed Paleozoic carbonate and clastic rocks and numerous areas of Paleozoic granite and igneous bodies. In the central part of the Basin, the basement is cut by an extensive, northerly-oriented Triassic rift system. Oil source rocks are mainly marine Jurassic and Lower Cretaceous bituminous shales. Trapping is structural and stratigraphic. The petroleum geology of the West Siberian Basin is discussed by Peterson and Clarke in their report titled "West Siberian Oil-Gas Province"(Appendix A).

\section{Production History}

The initial discovery in the basin, the Berezovo field, was made in 1953. It is a gas field in the northern Urals region. Production was not established until 1963 because of its remote location. The first major oil discovery was the Samotlor field in 1961. It is one of the largest oil fields in the world with an estimated ultimate oil recovery of 24.7 billion barrels. Samotlor production began in 1964 .

Development of oil production in the 1970 s was followed by development of gas resources in the northern portion of the Basin in the 1980s. In recent years, basin production has exceeded reserves replacement. Oil production has declined since 1988, and gas production began to decline in 1991. 


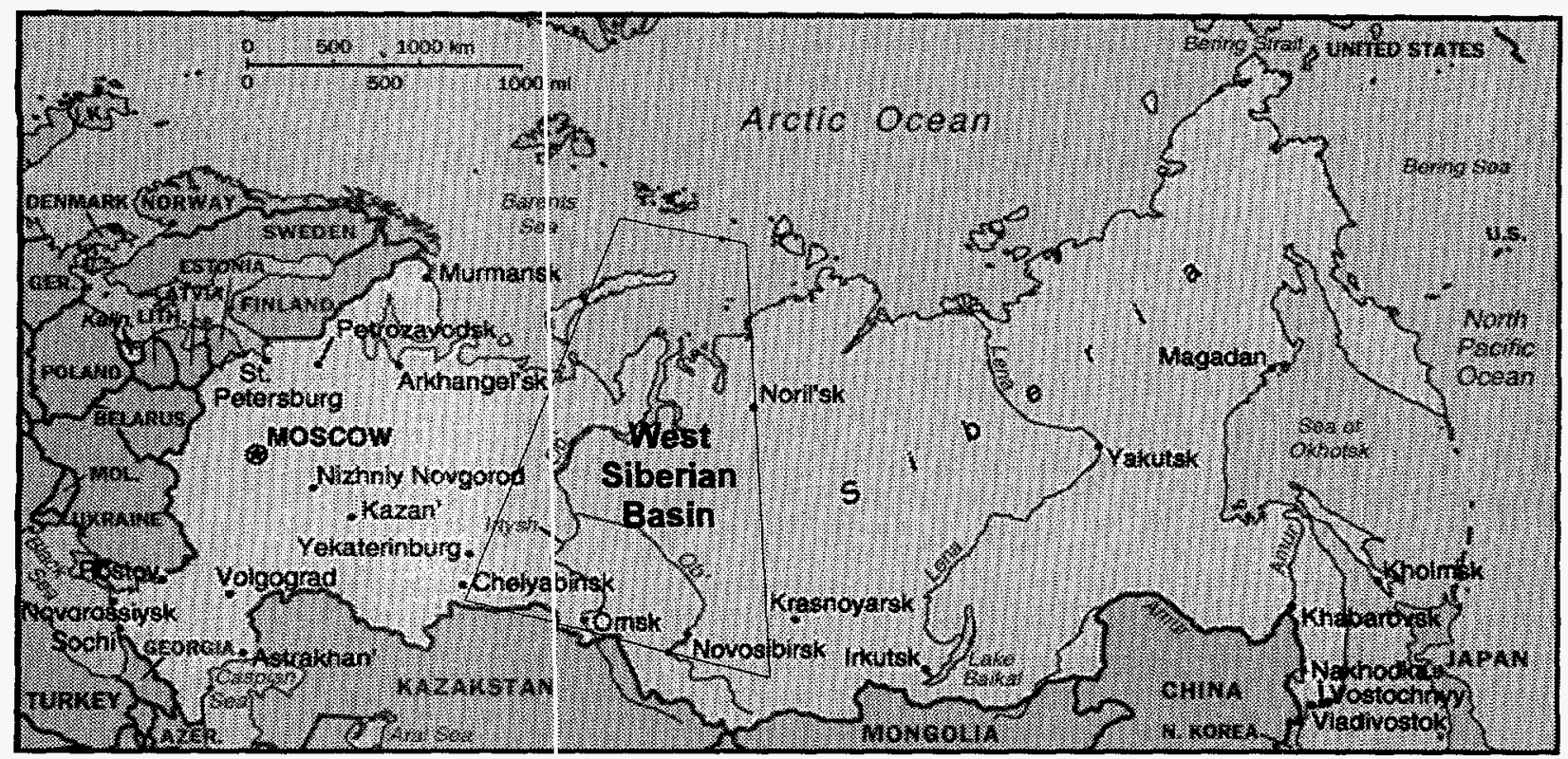

Source: Earth Science Associates, Arlington, $T X$.

Oil and condensate production in Russia has declined from a peak of 4.2 billion barrels in 1988 (11.5 million barrels per day) to 2.2 billion barrels in 1994 (6.0 million barrels per day). Production has s abilized with 1996 oil production approximately the sane as in 1994. West Siberian Basin oil production has drispped from a peak of 3.1 to 1.5 billion barrels ( 8.5 to 4.1 million barrels per day) during the same time. Peak gas production in Russia occurred in 1991 at 22.6 trillion cubic feet ( 62.2 billion cubic feet per day) and had declined to 21.9 trillion cubic feet ( 60.0 billion cubic feet per day) in 1993 with approximately 20.3 to 20.1 trillion cubic feet ( 55.6 to 55.2 billion cubic feet per day) from the West Siberian Basin.

\section{Economic Significarice}

Approximately 70 percent of the oil and 90 percent of the gas produced in Russia come from the West Siberian Basin. As Russia increasingly participates in the global economy, the importance of it; oil and gas resources will increase. Russia exports a isignificant amount of oil and gas to Europe and the republics of the FSU. Hard currency-generating exports to non-FSU countries have increased over the last several years as delinquent payments from FSU republics increased. A significant amount of Russia's oil and gas is consumed within Russia. Russia is the world's second largest consumer ${ }^{2}$ of natural gas and forth largest consumer of petroleum liquids behind the United States, Japan, and China. In 1995, oil and gas consumption was 1.07 billion barrels of petroleum liquids and 14.51 trillion cubic feet of natural gas. In comparison, the United States consumed 6.47 billion barrels of petroleum liquids and 21.65 trillion cubic feet of natural gas in 1995. The Russian petroleum industry supplies the consumption requirements of Russia plus the oil and gas for export. Further decline of Russian production could cause changes in the world petroleum markets as well as effect the economy and development of Russia. An assessment of the oil and gas resources and the potential for development of those resources in the West Siberian Basin is provided herein. 


\section{Largest Fields}

Several of the largest oil and gas fields in the world have been found in the basin. The five largest oil fields in this analysis represent approximately 30 percent of the discovered oil resources in the basin. The estimated ultimate recoverable oil from the largest oil field, Samotlor, is estimated as 24.7 billion barrels.
Cumulative production through 1993 is 17.9 billion barrels. The five largest gas fields contain 60 percent of the discovered nonassociated gas resources of the basin. The Urengoy field is the largest gas field in the basin with estimated total recovery of 269.6 trillion cubic feet and cumulative production of 108.5 trillion cubic feet through 1993. 


\section{Analysis Discussion}

\section{Basic Methods and Categories}

The database constructed for this study contains information on 1538 separate reservoirs, an average of approximately three reservoirs per field that has reservoir data reported. Some reservcir designations represent various subdivisions of geclogic intervals while others represent the entire geclogic interval. Each reservoir with reported data was assumed to contain producible hydrocarbons unles: noted as nonproductive in the data source. The locitions of fields within the basin and the location of fielcls that produce from selected common geologic intervals are shown in Appendix B.

The method used to estimate a recovery of oil and gas from each field involved the calculation of reservoir volumes within the individual fields. Known reservoir data were used to approximate any unknown information. Recovery was calculated for each reservoir indicated to be hydrocarbon bearing. The primary phase (gas or oil) was assumed tis fill the entire reservoir; therefore, gas-oil contacts wilhin individual reservoirs were not considered.

Volumetric methods used in the detirmination of reserves tend to produce optimistic estimates. Some of the estimates reflect data from initial discoveries or exploration prospects. Even though the method has limitations, it was chosen because suff cient field or reservoir performance data were not available to estimate the potential of the entire basill. Production history was considered unreliable for estimating recoverable oil and gas because recent pertormance may be the result of operational problems rather than natural depletion.

A recovery factor is applied to a volumetric estimate of original oil or gas in place in each rese'voir within a field. The resulting quantity is defined as estimated ultimate recovery. The Russian terminology would classify the volumes calculated in this analysis as A + $\mathrm{B}+\mathrm{C}_{1}$, with some volume in the $\mathrm{C}_{2}$ category. " $\mathrm{A}$ " reserves are considered developed producing; " $\mathrm{B}$ " are drilled and tested but not producing; " $\mathrm{C}_{1}$ " are partially evaluated, undeveloped, nonproducing; and " $\mathrm{C}_{2}$ " reserves have not been delineated by drilling. The field area data of this report may include areas that have not been delineated by drilling; therefore, some $\mathrm{C}_{2}$ reserves are likely in this report. The USGS estimate of undiscovered resources would be classified as $\mathrm{C}_{3}+\mathrm{D}_{1}$ in the Russian system.

The estimated ultimate recovery (EUR) calculated in this analysis is not defined by performance, economic limits of production, or costs of development. Therefore, a comparison to U. S. Reserve classifications can not be made. Additional field studies would be necessary to evaluate operational methods and expenses and capital requirements for development.

Performance and economic evaluations could then be used to determine the amount of proved and probable reserves are in the producing fields. Additional analysis would also be necessary to classify undeveloped estimated ultimate recoverable oil or gas as probable or possible.

\section{Basin Subdivisions}

Regional boundaries within the Basin were described by Maksimov ${ }^{3}$ and others (Figure 2). The areal subdivision of the basin used in this study follows the method adopted by Maximov and Peterson and Clarke. ${ }^{4}$ The ten Regions identified can be combined into four Areas having common characteristics (Table 1). Common geologic intervals within the Areas were combined for data analysis (Table 2). The linkage of geologic age with geologic interval and the areal subdivisions is shown as Table 3. 
Figure 2. Map of the Oil and Gas Regions and Areas of the West Siberian Basin

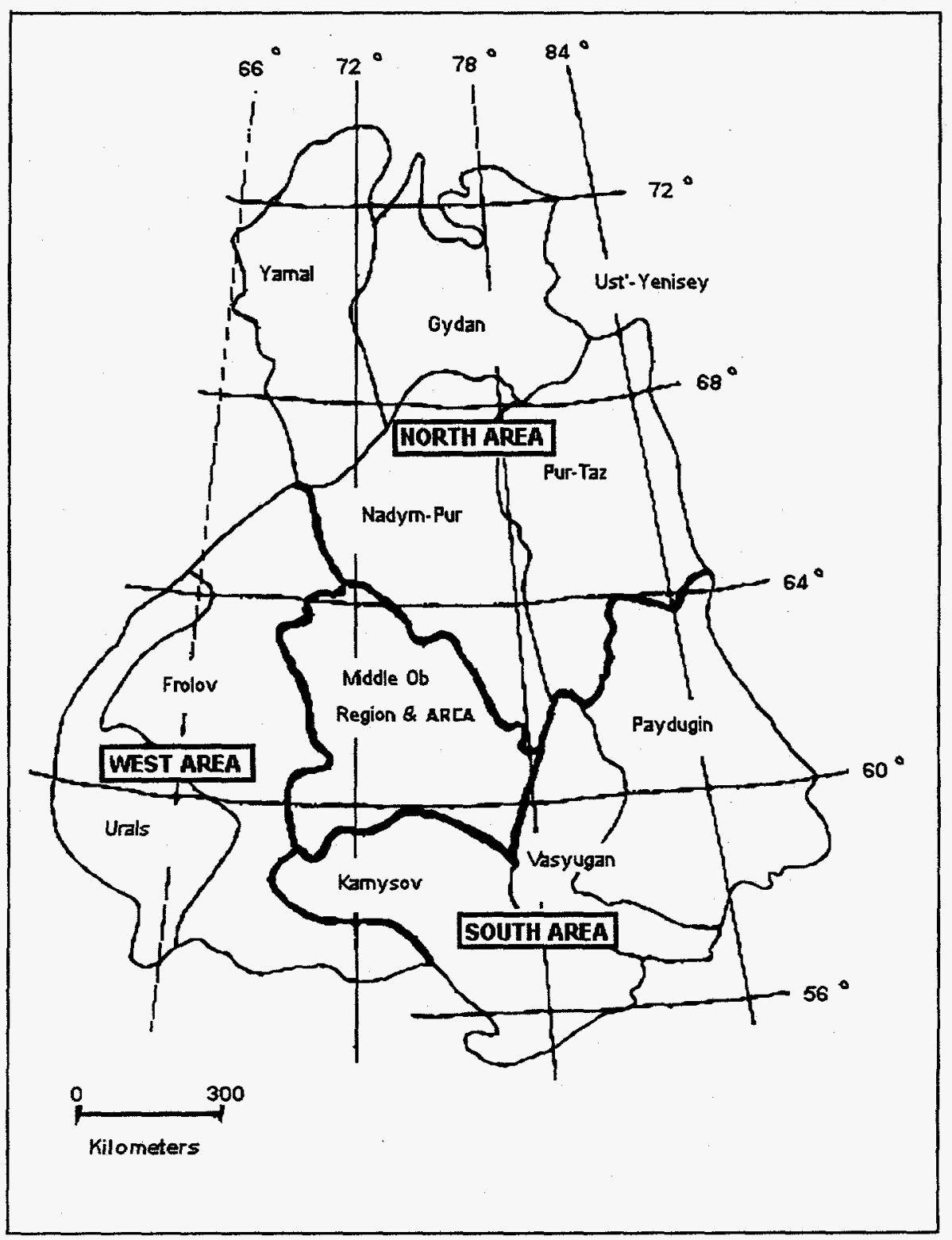

Source: Oil and Gas Fields of the U.S.S.R., Edited by S. P. Maksimov. 
Table 1. Regions Within Areas of the West Siberian Basin

\begin{tabular}{ll}
\hline Area & Region \\
\hline North & $\begin{array}{l}\text { Yamal } \\
\text { Gydan } \\
\text { Nadym- Jur } \\
\text { Pur-Taz }\end{array}$ \\
& Frolov \\
& Near Urials \\
West & Kaymysiov \\
& Vasyugen \\
South & Paydugin \\
& Middle Cib \\
\hline
\end{tabular}

Source: Department of the Interior, U.S. Gi»ological Survey.

\section{Table 2. Geologic Intervals Combined Within Productive Areas of the West Siberian Basin for Data Analysis}

\begin{tabular}{|c|c|}
\hline $\begin{array}{l}\text { Combined } \\
\text { Geologic Intervals }\end{array}$ & Productive Areas \\
\hline Upper Cretaceous & All Areas \\
\hline Albian - Aptian (North) & North \\
\hline Albian - Aptian (South) & $\begin{array}{l}\text { Middle Clb, West, \& } \\
\text { South }\end{array}$ \\
\hline Neocomian (North) & North \\
\hline Neocomian (South) & $\begin{array}{l}\text { Middle Cb, West, \& } \\
\text { South }\end{array}$ \\
\hline Jurassic (North) & North \\
\hline Jurassic (South) & South \\
\hline Jurassic (West) & West \\
\hline Jurassic (Ob) & Middle Oo \\
\hline Triassic-Paleozoic & All Areas \\
\hline
\end{tabular}

Source: Energy Information Administration, Olfice of Oil and Gas.

\section{Production by Area}

The northern portion of the basin produces primarily nonassociated gas and gas condensate from Upper Cretaceous. More than 90 percent of the discovered nonassociated gas in the basin is located in this area. The volume of discovered oil in the North Area ranks second to the Middle $\mathrm{Ob}$ Area.

The Middle Ob Region, in the central portion of the basin, is considered a single area. It is the major oil producing area of the basin. All but one field in the Middle $\mathrm{Ob}$ Area are considered primarily oil fields.

The West Area is productive in the Lower Cretaceous and Jurassic intervals. The West Area is generally gas productive in its northern portion and oil productive in its southern portion. Production in the South Area is predominantly oil from Jurassic intervals with some production from Lower Cretaceous intervals.

The number of fields in each of the four Areas is about evenly distributed, from 18 percent in the South Area to 34 percent in the Middle Ob Area. The locations of less than 2 percent of the fields are unknown. The database includes 634 oil and 147 gas fields for a total of 781 fields in the basin. Seven fields of the UstYenisey Region, which adjoins the Gydan Region along the northeastern edge of the basin, are included in the Gydan Region. Other sources may give a different count for the number of fields because of name changes, combining of fields within areas, or different translations of field names. Field locations are shown in Figure 3 with gas fields in red and oil fields in green. 
Table 3. Stratigraphic Chart Linking Geologic Age with Pay Zone Identifiers, by Area and Region, West Siberian Basin (Maksimov reference)

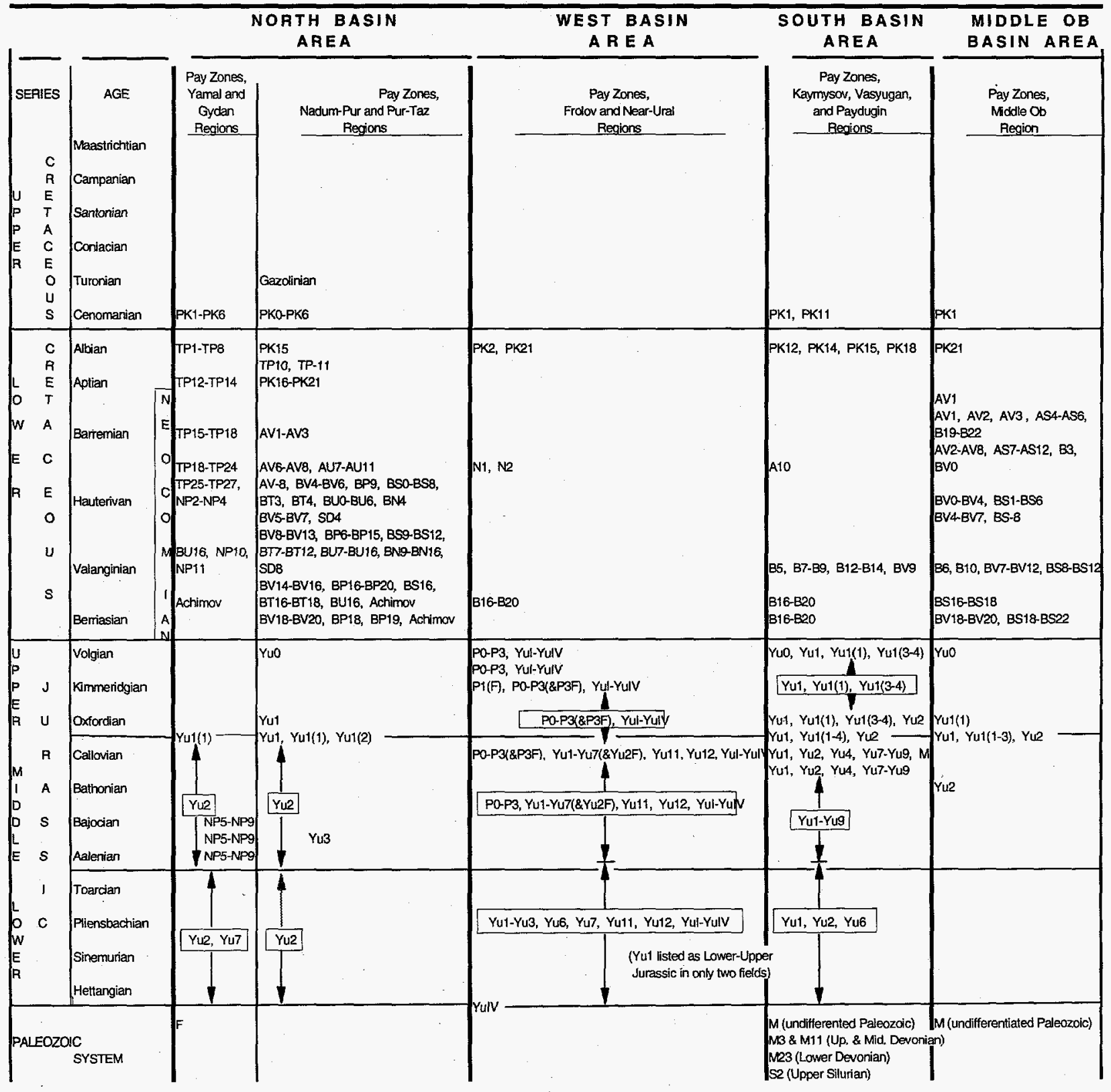

Notes: Apparent Russan alpha-numeric use for pay zone identifiers is to alpha-abbreviate names of formations, formation groups, series, or systems, then separate into numeric pay zones, analagous to formations and members.

Pay zones listed in between-age rows indicate age ranges (such as TP10 as Aptian-Albian age). The numbered pay zones increase with age (depth).

For Jurassic pay zones, the numbers in parentheses indicate further separations into sub-pay zones, again, increasing with age (depth). Other sub-pay zone designations are not listed, here, (

Partial abrictic Yu0 $=$ Bazhenov Shale formation: Yu11-Yu12 = Sherkalin member (bV many investigators).

Source: Extracted from reservoir-level listings in Oil and Gas Fields of the USSR--Volume II, edited by S.P. Maksimov, 1987. 
Figure 3. Location of Oil and Gias Fields in the West Siberian Basin.

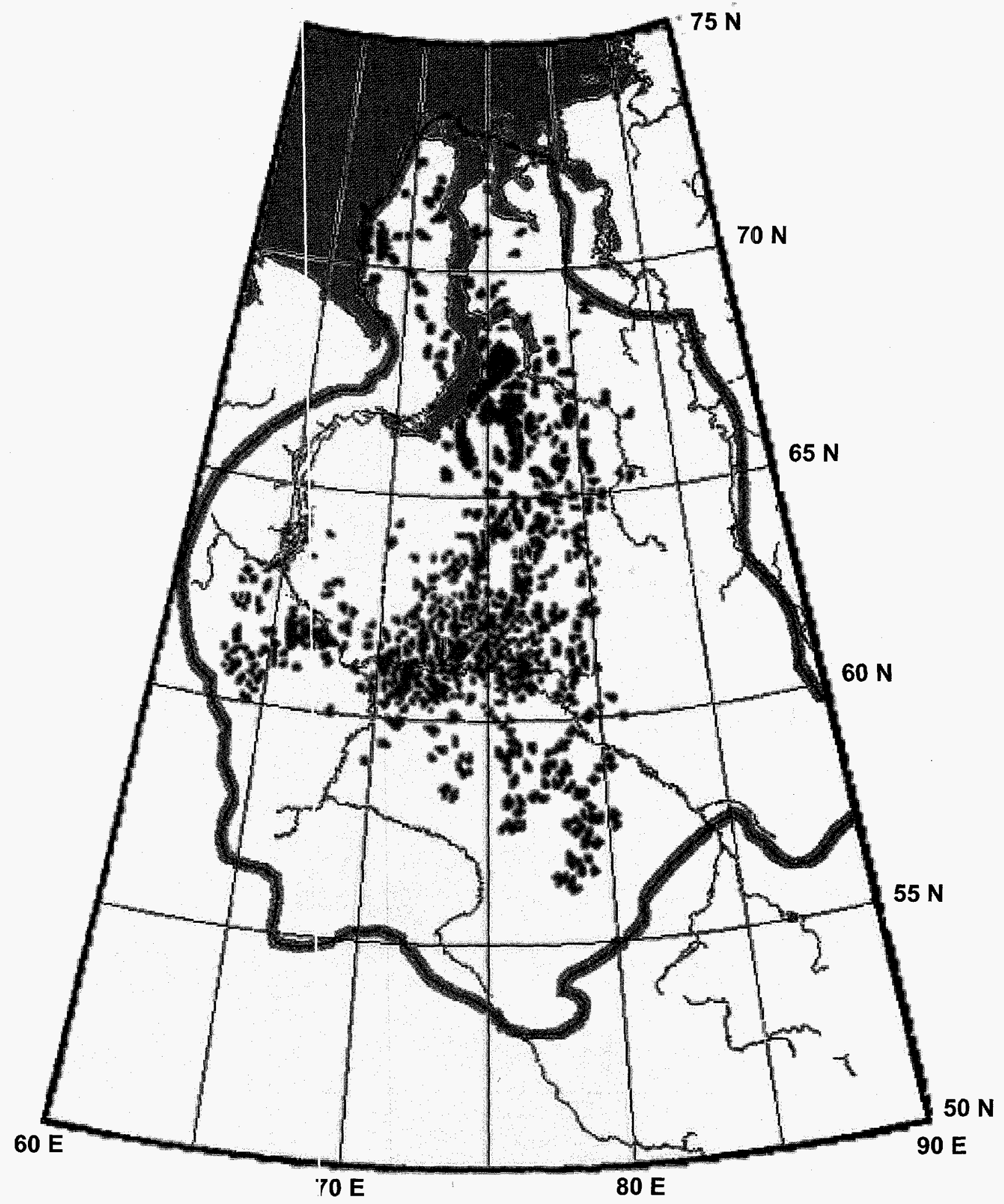

Source: Earth Science Associates, Arlingtorı, TX. 


\section{Data Description}

\section{Available Data}

Reservoir data were acquired from several published sources. Agreement was found between the data sources, suggesting a single original source. Where differences were noted, the most recent information was used. Differences in translation and nomenclature and additional development between reporting dates of data account for some data differences. Multiple discoveries combined into single fields as development progressed and fields combined under Regional geologic province names may also account for some duplication of information. Primary data sources are listed below.

Oil and Gas Fields of the USSR (In Russian), edited by S.P. Maksimov, 1987.

Gas and Condensate Fields - Reference Book (in Russian), by I. P. Zhabrev, 1983.

Atlas of Key Hydrocarbon Basins of the Former Soviet Union, Compiled by K. L. Talley, 1993.

Field and reservoir data from Petroconsultants S.A., Geneva, Switzerland, August 1995.

Conversation with G. Ulmishek, USGS, Denver, CO, 1997.

The West Siberian Basin's fields can be divided into three groups according to the available data. Most of the fields had very little data missing so few assumptions or data constructions were needed to develop an estimate of recoverable oil and gas. These fields represent 94 percent of the estimated discovered oil volume and 98 percent of the calculated discovered gas volume of the basin.

The second group had significant data missing for some fields but the available data were sufficient to apply correlations to estimate missing data. Little information was known about the third group of fields. Low confidence in the calculated oil or gas volume of these few fields resulted. Less than 0.02 percent of the estimated ultimate recovery falls in this low-confidence category.
Most of the reported reservoir parameter data were represented as reservoir averages. Ranges of data were reported for reservoirs within some fields. When a range of data was reported, an average value was used to represent the reservoir. Often, data used to represent a field was taken only from the discovery well. Calculated reserves were reported in data sources for some fields but were used only to compare with values calculated here.

As an indicator of data availability, the amount of available area, gross pay, net pay, porosity, and permeability data were calculated as a percentage of the number of reservoirs in each geologic interval (Table 4).

\section{Estimated Data}

Estimates of some reservoir data were necessary for all fields to accomplish volumetric calculations. The available data were sufficient to make reasonable engineering estimates of missing information. Except for reservoir temperature and pressure, those estimates were made within geologic intervals over common analogous areas. Graphical displays of data were used to visually evaluate the consistency or variations in the data. Details of the methods used in estimating data are reported in Appendix B.

A single linear function of depth was used to estimate unknown pressures in all Regions of the basin. A linear equation was developed for each of the four Areas of the basin to calculate reservoir temperature as a function of depth.

All other properties were determined within geographic boundaries described by Maksimov and combinations of geologic intervals described by Peterson and Clarke. Much of the data were reported for subdivisions of the major geologic intervals. Missing information was determined by averaging and analyzing data within major geologic intervals. Distributions of the data within the areal and geologic subdivisions of the basin were graphed and analyzed to evaluate consistency and to choose the best value to represent the combination of location with geologic interval. 


\section{Data Correlation:s}

Reservoir fluid volume factors were determined using correlations programed for personal computer spreadsheet software ${ }^{5}$. The West Siberian Basin oil and gas characteristics presented no special problems in the determination of fluid properties. The oil is a medium to high API gravity and does not contain sufficient hydrogen sulfide or other impurities that would affect the use of correlations to determine fluid properties. The nonassociated gas is primarily methane without significant inert impurities or intermediate components. Correlations can be used to calculate solution gas-oil ratios and bubble point pressures that mittch available data and reservoir performance.

Some volumetric calculations could be in error using the reported field productive areas. Rsported areas may be from seismic interpretations or exploration mapping. Many fields are not completely developed; therefore, areas are not accurately defined. Area data were reported as the total field areal exter $t$, the area of the largest reservoir, or the area of each individual reservoir. Area data were not reported for some fields. A method, described in Appendix B, assigned an area to each individual reservoir in a field for the calculation of initial oil or gas in place.
More data for gross pay thickness were available than for net pay thickness data. A net-to-gross ratio was calculated when both net and gross data were known. The average net-to-gross ratio of a Region was used to estimate net pay when gross pay was reported. The net pay values that could not be calculated from gross pay were assumed to be equal to the average net pay of the Region.

Very little water saturation data were available. A correlation developed by Schlumberger ${ }^{6}$ was used to calculate irreducible water saturation for each reservoir for which an average permeability was reported. The distribution of calculated water saturation was plotted to examine the results. The calculated water saturation for some combinations of parameters was outside the normal range of saturations anticipated for productive reservoirs. To screen out these values, the mode of the calculated saturations was used in the volumetric estimates of original oil and gas in place.

Porosity was the reservoir parameter most often available among those reservoir parameters used to calculate oil or gas in place. Missing porosity data were estimated from distribution graphs using the method described in Appendix B.

Table 4. Percentage of Reservoirs with Data Available within Major Geologic Intervals of the West Siberian Basin

\begin{tabular}{lcccccc}
\hline Geologic Interval & Area & & Gross Pay & Net Pay & Porosity & Permeability \\
\hline & & & & & \\
Upper Cretaceous (All Areas) & 92 & 98 & 57 & 74 & 68 \\
Albian - Aptian (N) & 89 & 100 & 24 & 52 & 39 \\
Albian - Aptian (S) & 79 & 91 & 30 & 76 & 73 \\
Neocomian (N) & 88 & 95 & 28 & 71 & 65 \\
Neocomian (S) & 77 & 95 & 42 & 80 & 77 \\
Jurassic (N) & 100 & 100 & 56 & 80 & 76 \\
Jurassic (S) & 95 & 99 & 68 & 99 & 95 \\
Jurassic (W) & 90 & 97 & 43 & 95 & 90 \\
Jurassic (Middle Ob) & 85 & 95 & 55 & 79 & 77 \\
Triassic - Paleozoic (All Areas) & 94 & 80 & 43 & 100 & 80 \\
\hline
\end{tabular}

Note: N, S, W, and Middle Ob refer to the fo $\mathrm{dr}$ Basin areas of Table 2.

Source: Energy Information Administratior, Office of Oil and Gas. 


\section{Ultimate Recovery Determination}

\section{Methodology}

Estimated ultimate recovery was determined for each reservoir within the discovered fields using the procedures described in Appendix C. The EUR represents the maximum expected recovery of oil or gas from a productive reservoir without regard for economic limitations. The methodology used can be applied to all fields in a consistent manner. The basic method requires a volumetric determination of original oil or gas in place. A recovery efficiency is then applied to determine the recoverable oil. For gas, an abandonment pressure is assumed for estimating the recovery efficiency. Recovery estimates are summed to produce a total EUR for each field. The average recovery efficiencies are reported for each Region of the basin in Table 5. Results are also tabulated by field producing status for oil and gas (Tables 6 and 7).

Table 5. Average Reservoir Recovery by Regions of the West Siberian Basin as a Percent of Original Oil or Gas in Place

\begin{tabular}{lccc}
\hline Region & $\begin{array}{c}\text { Primary Oil } \\
\text { Recovery }\end{array}$ & $\begin{array}{l}\text { Total Oil } \\
\text { Recovery }\end{array}$ & $\begin{array}{l}\text { NA Gas } \\
\text { Recovery }\end{array}$ \\
\hline Yamal & 19.3 & 38.6 & 79.7 \\
Gydan & 16.8 & 33.6 & 78.2 \\
Nadym-Pur & 19.5 & 39.0 & 78.5 \\
Pur-Taz & 18.8 & 37.6 & 79.1 \\
Frolov & 15.3 & 30.6 & 77.8 \\
Near Urals & 18.3 & 36.3 & 61.4 \\
Kaymysov & 17.2 & 35.2 & 78.2 \\
Vasyugan & 18.8 & 37.6 & 79.3 \\
Paydugin & 19.2 & 38.4 & 79.5 \\
Middle Ob & 17.5 & 35.0 & 79.6 \\
& & & \\
Average & 18.1 & 36.2 & 77.1 \\
\hline
\end{tabular}

Note: NA Gas is nonassociated gas.

Source: Energy Information Administration, Office of Oil and Gas.

\section{Oil Recovery}

Recovery from oil reservoirs was estimated for primary depletion and improved recovery efficiency. The total recovery was the sum of the estimated primary recovery with improved recovery volumes added based on the assumptions listed below.

\section{Primary Recovery}

Primary recovery averaged 18.1 percent of the original oil in place across the basin. Primary recovery is the sum of the recovery from the initial pressure to the bubble point pressure as calculated by fluid expansion and the recovery below the bubble point pressure calculated using a statistical correlation from the American Petroleum Institute (API). ${ }^{7}$ This correlation is provided in Appendix C. Although the validity of this correlation is questionable, the results are within an expected range for the properties of the basin. The correlation provides a method that can be applied to account for reservoir property changes within the basin and to obtain consistent results across the basin.

\section{Improved Recovery}

Improved recovery assumed that all oil reservoirs would be subjected to improved recovery techniques (such as waterflooding) except those reservoirs below the Jurassic section or with permeabilities less than 10 millidarcys. Oil reservoirs within predominantly gas fields and reservoirs in the Bazhenoy shale formation were also excluded. API statistical correlations for water drive recovery that assume full development and continuity within the reservoir, calculated an average ultimate recovery of 54.5 percent of the original oil in place. This calculated recovery was assumed not to be representative of recovery from an improved recovery project. Field recovery was reduced because of geographic and environmental limitations. Reservoir stratification and discontinuities were also assumed to reduce the recovery efficiency. The incremental improved oil recovery was reduced to a value equal to the calculated primary recovery in reservoirs that would be subject to an improved recovery process.

\section{Recovery Efficiency}

The average total oil recovery efficiency, including potential improved recovery, from fields in the basin was 36.2 percent of the original oil in place. 


\section{Producing Fields}

The fields that are currently proclucing have an estimated original recoverable oil and condensate volume of approximately 115.1 billion barrels. No improved recovery oil was included for fields currently producing under primary depletion. Cumulative oil and condensate production through 1994 was 49.3 billion barrels leaving 65.8 billion barrels to be produced from fields that are currently producing.

\section{Nonproducing Fields (Undivveloped)}

The discovered fields that are not on production contain an estimated 51.0 billion barrels of recoverable oil and condensate. This value includes 20.6 billion barrels of oil added for potential improved oil recovery. Primary oil recoverable from discovered, nonproducing fields is estimated to be 30.4 billion barrels.

\section{Discovered Fields}

Total discovered ultimate recoverable oil and condensate in the basin are about 166.1 billion barrels. Subtracting cumulative production of 49.3 billion barrels of oil and condensate results. in remaining reserves of all classes of 116.8 billion barrels. Assuming only primary recovery from nonproducing fields reduces the volume to 96.2 billio 1 barrels. This volume includes five billion barrels of condensate to be produced with nonassociated gas. No probability of attaining the calculated recovery (risk) was applied to any of the estimates of discovered reserves. Therefore the range of recovery from discovered fields is 96.2 to 116.8 billion barrels.

\section{Undiscovered Resources}

Undiscovered resources are the mean value of the USGS $^{8}$ assessment of undiscovered oil and condensate totaling 52.4 billion barrels. Two tillion barrels discovered since the estimate was made in 1993, which are included in the current database of ciscovered oil, have been subtracted from the estimate of undiscovered resources.

\section{Remaining Resources}

Adding the undiscovered resources to the discovered EUR yields a maximum remaining futurs potential for the basin of between 146.6 and 167.2 billion barrels of oil and condensate to be discovered, $d \epsilon$ veloped, and produced. The original resources of the basin were estimated to be 216.5 billion barrels of oil and condensate.

\section{Gas Recovery}

Estimated ultimate recovery for gas reservoirs was calculated from an initial pressure to an abandonment pressure of 0.1 psi per foot of depth to the reservoir. This does not represent an economic limit but serves as a consistent lower pressure limit applied across the basin. Calculated recoveries range from 61.4 percent to 79.9 percent of the initial gas in place (Table 7).

\section{Producing Fields}

Fields that are producing contained estimated ultimate recoverable gas of 765 trillion cubic feet of gas. Of this total, nonassociated gas fields account for 711 trillion cubic feet and associated-dissolved gas from oil reservoirs accounts for 54 trillion cubic feet. The remaining estimated gas reserves of fields that are currently producing are 551 trillion cubic feet after subtracting 214 trillion cubic feet of produced gas.

\section{Nonproducing Fields (Undeveloped)}

Discovered, undeveloped reservoirs contain 341 trillion cubic feet of recoverable gas to be developed and produced. Of this volume, 322 trillion cubic feet are in nonassociated gas reservoirs and 19 trillion cubic feet are associated-dissolved gas in undeveloped oil fields.

\section{Discovered Fields}

The total discovered EUR gas, including 73 trillion cubic feet of associated-dissolved (AD) gas from oil reservoirs and 1,033 trillion cubic feet of nonassociated (NA) or gas well gas, are 1,106 trillion cubic feet. Subtracting cumulative gas production of 214 trillion cubic feet through 1993 from the total leaves 892 trillion cubic feet to be recovered from discovered reservoirs. The volume does not include gas from the Leningradskoye and Rusanovskoye fields in the Kara Sea. Other sources estimate recovery potential of between 85 and 282 trillion cubic feet from these two fields. Sufficient information was not available to make an independent estimate of these offshore discoveries; they are included only as a comment.

\section{Undiscovered Resources}

A statistical mean value of undiscovered nonassociated gas resources of 1,090 trillion cubic feet was estimated by the USGS as of 1993. The current data base includes six trillion cubic feet of gas discovered after 1993. The remaining undiscovered resources therefore are 1,084 trillion cubic feet. 


\section{Remaining Resources}

Future gas potential in the basin is 1,975 trillion cubic feet, the sum of the remaining recoverable discovered gas and the USGS mean estimate of undiscovered gas. The original gas resource potential of the basin is estimated to be 2,189 trillion cubic feet. No probability of occurrence or risk was applied to the estimates of the discovered gas volume.

\section{Condensate Recovery}

Ultimate condensate recovery was calculated for those gas fields where the liquid content of the produced gas was reported. A volume of five billion barrels from the fields that are on production was calculated. The USGS estimate of undiscovered resources includes four billion barrels of condensate. Reported production of oil includes condensate; therefore, the estimated volume of condensate was added to the oil volume in this analysis.

Table 6. Estimated Oil and Condensate Resources in the West Siberian Basin, End of 1994 (Billion Barrels)

\begin{tabular}{lcc}
\hline $\begin{array}{l}\text { Resource } \\
\text { Description }\end{array}$ & $\begin{array}{c}\text { Total } \\
\text { Recovery }\end{array}$ & $\begin{array}{c}\text { Remaining } \\
\text { Recovery }\end{array}$ \\
\hline Discovered & & \\
$\quad$ Producing Fields & & - \\
$\quad$ Primary Producing Fields & 13.8 & - \\
$\quad$ Improved Recovery Producing Fields & 96.3 & - \\
$\quad$ Condensate & 5.0 & 65.8 \\
$\quad$ Subtotal & 115.1 & - \\
$\quad$ Nonproducing Fields & & - \\
$\quad$ Primary Recovery & 30.4 & \\
$\quad$ Potential Improved Recovery & 20.6 & 116.8 \\
$\quad$ Subtotal & 51.0 & - \\
Total Discovered & 166.1 & - \\
$\quad$ Undiscovered $\quad$ Oil & & 50.4 \\
$\quad$ Condensate & 46.4 & 167.2 \\
Total Undiscovered & 4.0 & \\
$\quad$ Total Basin Resources & 50.4 & \\
Cumulative Production & 216.5 & \\
\hline
\end{tabular}

Note: Original USGS estimates of undiscovered oil and condensate were 52.4 billion barrels. The database of discovered fields includes two billion barrels discovered since the USGS estimate.

Sources: Discovered - Energy Information Administration, Office of Oil and Gas

Undiscovered - U. S. Geological Survey, "Estimated Petroleum Resources in the Former Soviet Union," G. Uimishek and C. Masters, Open-File Report 93-316, March 1993, Denver, Colorado. 
Table 7. Estimated Natural Gas Resources in the West Siberian Basin, End of 1993 (Trillion Cubic Feet)

\begin{tabular}{|c|c|c|}
\hline $\begin{array}{l}\text { Resource } \\
\text { Description }\end{array}$ & $\begin{array}{l}\text { Total } \\
\text { Recovery }\end{array}$ & $\begin{array}{l}\text { Remaining } \\
\text { Recovery }\end{array}$ \\
\hline \multicolumn{3}{|l|}{$\begin{array}{l}\text { Discovered } \\
\text { Producing Fields }\end{array}$} \\
\hline Nonassociated & 711 & - \\
\hline Associated-Dissolved & 54 & - \\
\hline Subtotal & 765 & 551 \\
\hline \multicolumn{3}{|l|}{ Nonproducing Fields } \\
\hline Nonassociated & 322 & - \\
\hline Associated-Dissolved & 19 & - \\
\hline Subtotal & 341 & \\
\hline Total Discovered & 1,106 & 892 \\
\hline Undiscovered & 1,084 & - \\
\hline Total Basin & 2,189 & 1,975 \\
\hline Cumulative Production & -214 & \\
\hline
\end{tabular}

Note: Original USGS estimate of undisccvered gas was 1090 trillion cubic feet. Discovered database includes 6 trillion cubic feet discovered since estimate.

Source: Discovered - Energy Information idministration, Office of Oil and Gas, Undiscovered - U. S. Geological Survey, "Estimated Petroleum Resources in the Former Soviet Union," G. Ulmishek and C. Masters, Open-File Report 93-316, March 1993, Denver, Colorado.

\section{Field Size Distribution}

The average field size in the basin is 248 million barrels for oil fields and 5.3 trillion cubic feet for nonassociated gas fields. The giant fielis of the basin cause the average to be much larger than the mode of the field size distribution. Giant fields, difined as those that contain more than 500 million barrels of recoverable oil or the equivalent in gas (roughly 3 trillion cubic feet). Although the potential exist to discover additional giant fields, many smaller fields that are included in this analysis may not be Jeveloped for economic reasons. The field size distribuions (Figures 4 and 5) show a mode of approximately 25 million barrels or 400 billion cubic feet of recoverable oil or gas. 
Figure 4. Crude Oil Field Size Distribution for Discovered Felds, West Siberian Basin.

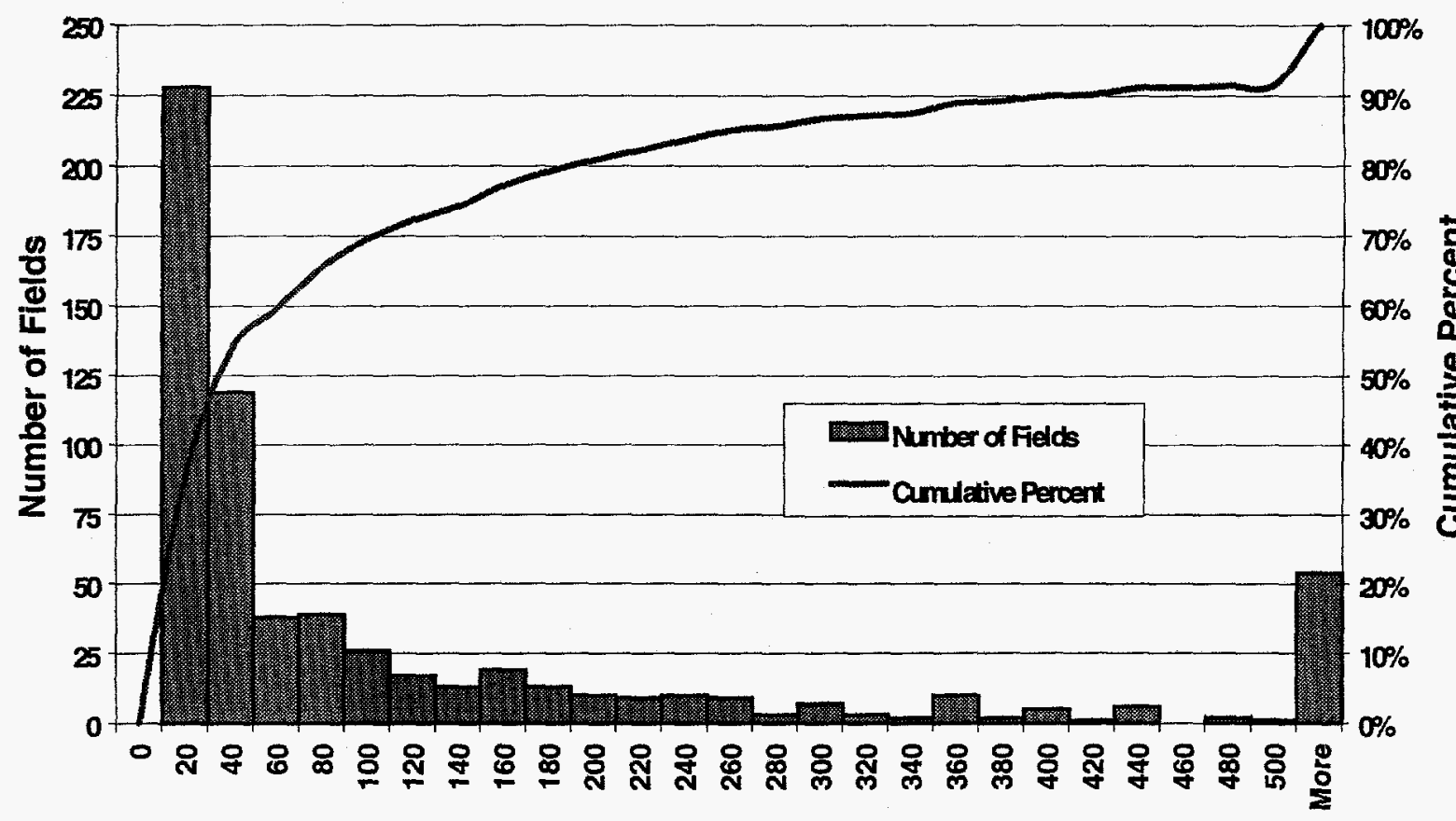

Fieid Size (Millions of Barreis)

Source: Energy Informetion Adtrinistration, Office of Ol and Gas.

Figure 5. Gas Field Size Distribution for Discovered Fields, West Siberian Basin.

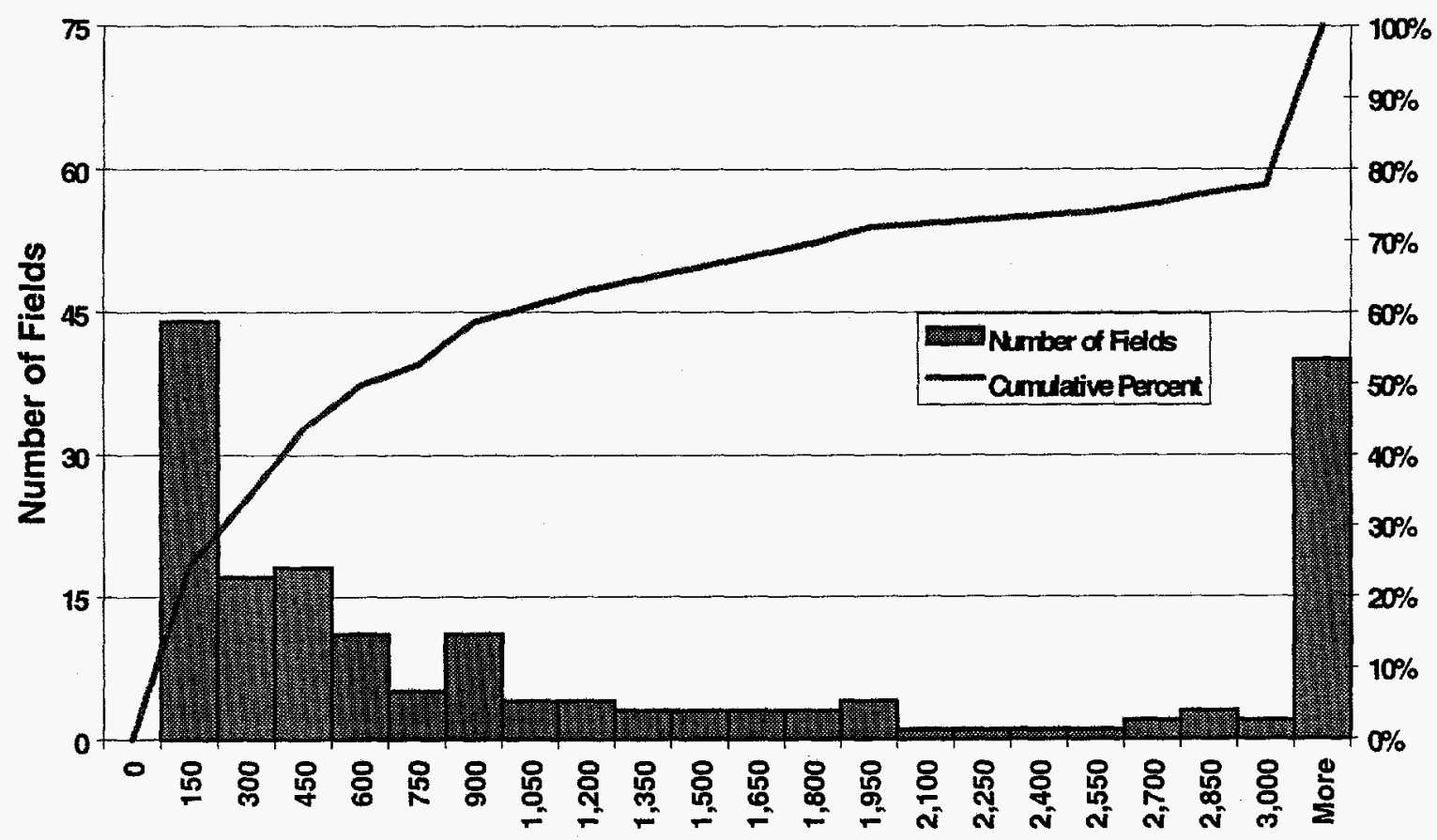

Cas Field Size (Billions of Cubic Feet)

Source: Energy Information Adrinistration, Office of Oil and Gas. 


\section{Geographic Distrilution}

The estimated recovery for each Region in the basin is tabulated in Table 8. Totals for each Area are also presented. The field summaries tabulated in Appendix D are sorted alphabetically. Also included are tabulations of the field data by Regions of the basin. The information includes field location, discovery date, production status, and primary product. The complete data base and the calculated results for each reservoir are available on a computer diskette in a self-extracting spreadsheet file. To obtain a copy, contact the EIA Dallas Field Office at (214) 720-6150.

Table 8. Discovered Oil and Ga:s by Region and Area, West Siberian Basin (Million Barrels Oil and Condensate; Billion Cubic Feet Gas)

\begin{tabular}{|c|c|c|c|c|c|c|}
\hline \multirow{2}{*}{$\begin{array}{l}\text { Region } \\
\text { Area } \\
\end{array}$} & \multicolumn{2}{|c|}{ Number of Fields } & \multicolumn{2}{|c|}{ Ultimate Recovery } & \multicolumn{2}{|c|}{ Ultimate Recovery } \\
\hline & Oil & Gas & Oil & AD Gas & NAGas & Condensate \\
\hline Yamal & 0 & 27 & 141 & 35 & 194,998 & 590 \\
\hline Gydan & 2 & 22 & 282 & 221 & 71,419 & 52 \\
\hline Nadym-Pur & $5 \overline{8}$ & 29 & 28,170 & 23,022 & 581,721 & 2,742 \\
\hline Pur-Taz & 34 & 20 & 11,973 & 5,908 & 152,278 & 1,057 \\
\hline North Area & 94 & 98 & 40,566 & 28,965 & $1,000,416$ & 4,441 \\
\hline Frolov & 59 & 7 & 10,505 & 3,045 & 1,286 & 16 \\
\hline Near Urals & 65 & $? 5$ & 2,733 & 1,080 & 6,119 & 67 \\
\hline West Area & 124 & 32 & 13,238 & 4,125 & 7,405 & 83 \\
\hline Kaymysov & 73 & 3 & 4,812 & 4,489 & 3,663 & 78 \\
\hline Vasyugan & 61 & 6 & 3,919 & 2,155 & 14,153 & 334 \\
\hline Paydugin & 6 & 4 & 349 & 92 & 840 & 21 \\
\hline South Area & 140 & 13 & 9,080 & 6,736 & 18,656 & 433 \\
\hline Middle Ob & 263 & 2 & 98,227 & 33,160 & 6,720 & 61 \\
\hline Unknown & 13 & 2 & 26 & 13 & 30 & 0 \\
\hline Total Basin & 634 & 147 & 161,137 & 73,220 & $1,033,227$ & 5,017 \\
\hline
\end{tabular}

Note: AD Gas is associated-dissolved gas and NA Gas is nonassociated gas.

Source: Energy Information Administratior, Office of Oil and Gas. 


\section{Production Projections}

\section{Future Discoveries}

In 1993, the USGS mean estimate of the undiscovered oil and gas resources of the West Siberian basin were 52.4 billion barrels of oil and condensate and 1,090 trillion cubic feet of gas. Condensate included was four billion barrels. Most of this additional supply will likely be found in stratigraphic traps and structures smaller than those currently known. Some new production will come from less productive and deeper reservoirs. Adding these amounts (adjusted for discoveries after 1993) to the estimated amounts discovered provides the resources for the basin of 216 billion barrels of oil and condensate and 2,189 trillion cubic feet of gas. Subtracting production leaves 167 billion barrels and 1,975 trillion cubic feet to be produced, developed, and discovered.

To project a schedule of the future discoveries, a modified method of Dr. M. King Hubbert ${ }^{9}$ was used, utilizing a modified logistic function developed by the EIA. ${ }^{10}$ EUR discovered oil and gas plotted at the date of discovery with an end point equal to the total basin resources are $\mathrm{fit}^{11}$ with the logistic function (Figures 6 and 7). The function obtained by the curve fit was then used to schedule future discoveries for the amount of the basin resources. The total basin recovery used in the calculation was the sum of the EIA estimate of discovered fields and the USGS estimate of undiscovered resources.

\section{Future Production}

Theory suggests that production should follow discoveries with an appropriate time lag for development. Production in the West Siberian basin has not followed this model because of the remote arctic environment and unique problems associated with Russian development practices (full field delineation before beginning production development). Another method, described in Appendix C, was therefore developed to project future production. A declining ratio of the remaining EUR divided by the annual production (R/P ratio) was used to schedule production based on the discovery schedule developed using the logistic function.

\section{Oil and Condensate}

The oil resources in the basin should support production greater than the production rate that existed before the decline that began in 1988 (from 3.1 to 1.5 billion barrels per year or 8.5 to 4.1 million barrels per day in 1994). A theoretical peak annual production rate of 4.1 billion barrels per year (11.2 million barrels per day) was calculated to be possible in the years 2006 to 2009 before a decline begins (Figure 8). Three forecast cases were projected to show the range of production potential beginning at the 1994 annual rate of 1.46 billion barrels (Figures 9 and 10).

The most severe case (Continued Decline Case) assumes that production continues to decline at the recent rate of 16 percent per year to 100 million barrels (MMbbls) in the year 2010. Remaining recovery would be less than 10 billion barrels. This is less than, but approximates, the remaining estimated primary recovery of 15 billion barrels in the fields that are currently producing. As depletion occurs, the decline of the producing rate could decrease or become hyperbolic, extending the producing life, and approaching the 15 billion barrel estimate.

A second case (No New Discoveries Case) assumes that oil production can be stabilized at the current rate for a period of time and will then decline at the theoretical rate to a recovery of the remaining 96.2 billion barrels from discovered fields. Only primary recovery of 30.4 billion barrels from nonproducing fields was considered. No additional discoveries would occur. In this case, the current rate of approximately 1.46 billion barrels per year ( 4.0 million barrels per day) could be maintained until the year 2051 before the decline begins. 
Figure 6. Cumulative Discovered Crude Oil, West Siberian Basin

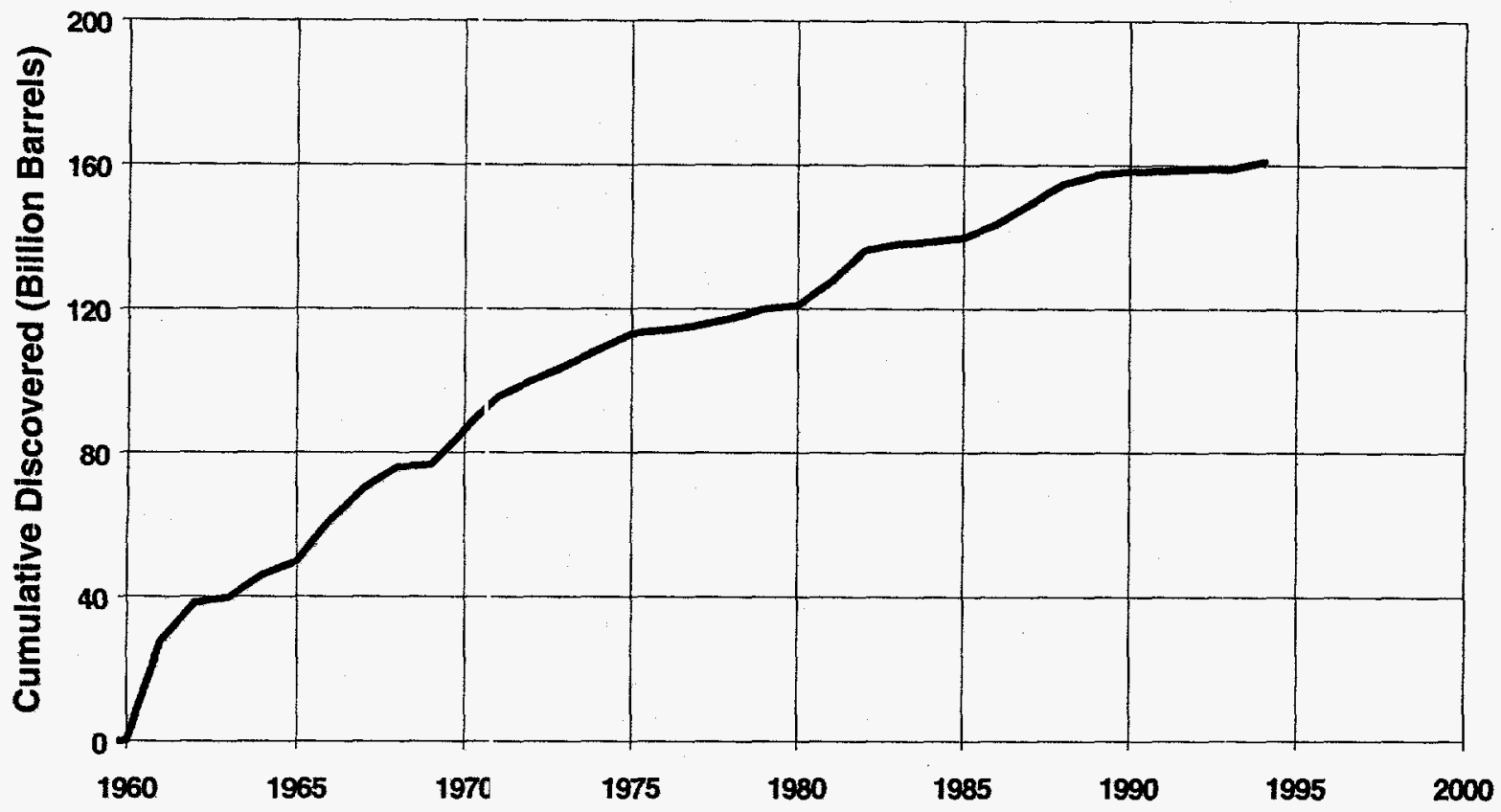

Source: Energy Information Administration, Office of Oil and Gas

Figure 7. Cumulative Discovereel Natural Gas, West Siberian Basin

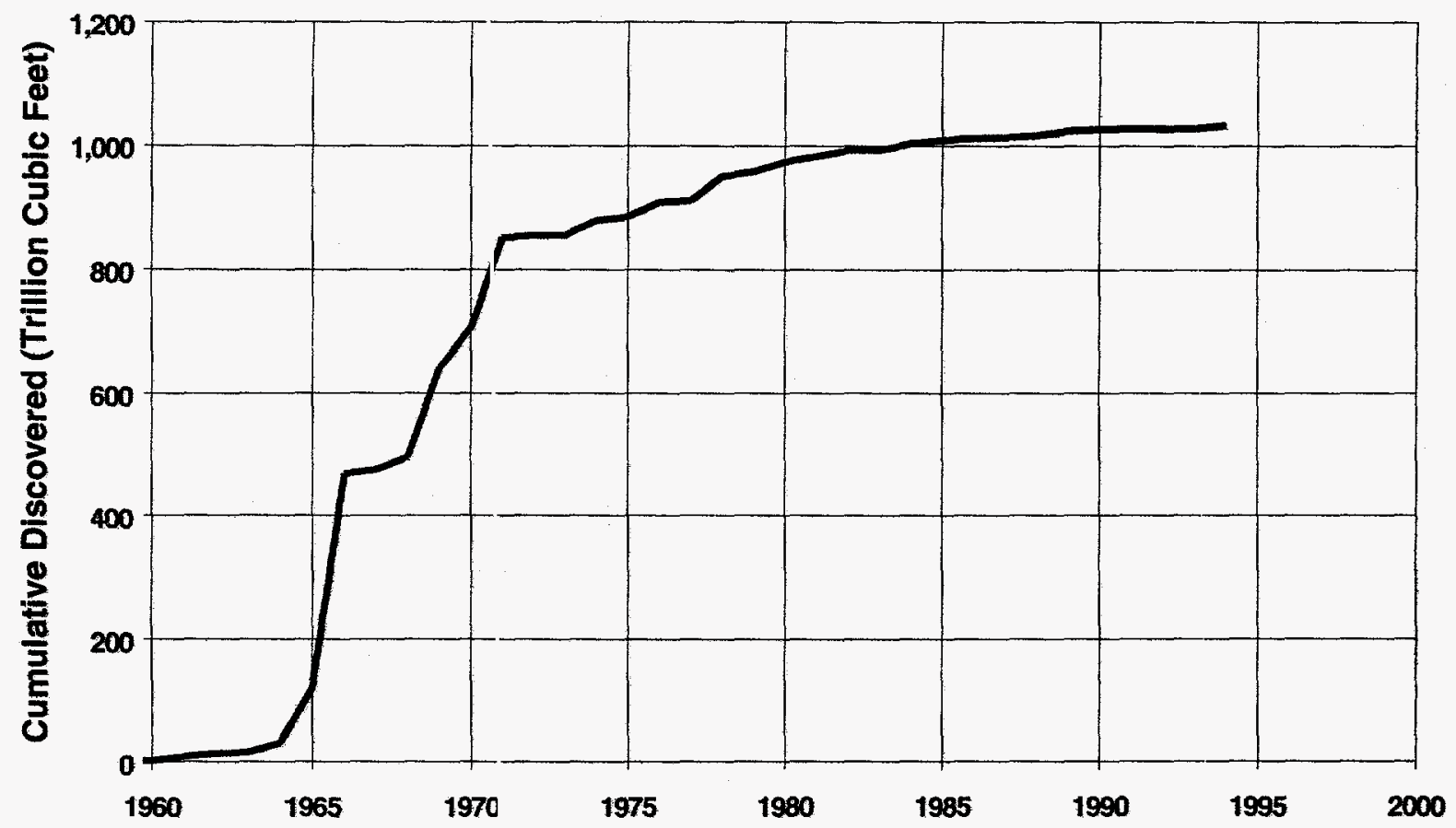

Source: Energy Information Administration, Office of Oil and Gas. 
Figure 8. Total Oil and Condensate Discoveries and Theoretical Production, West Siberian Basin

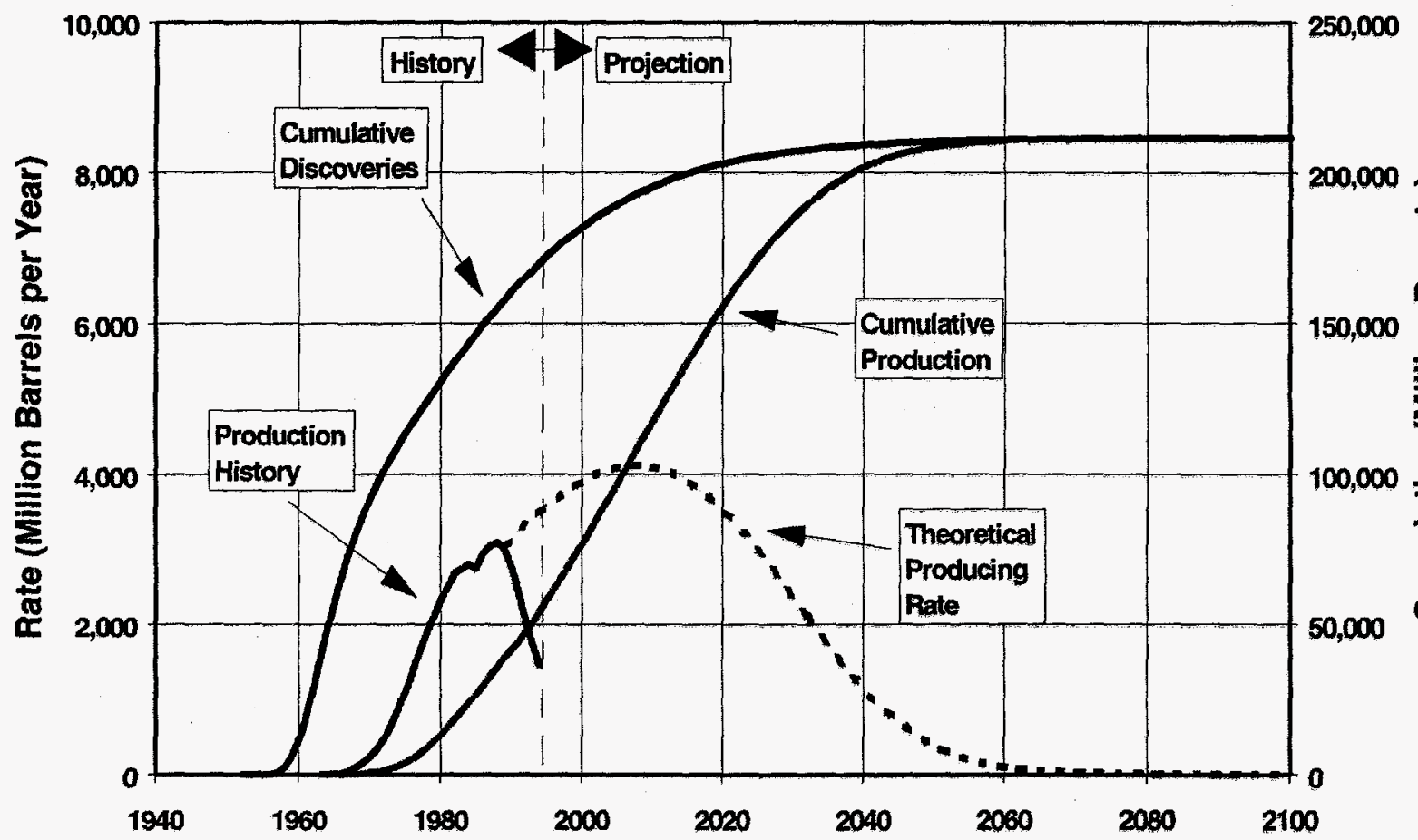

Source: Energy Information Administration, Office of Oil and Gas. 
Figure 9. Projected Oil Production, West Siberian Basin

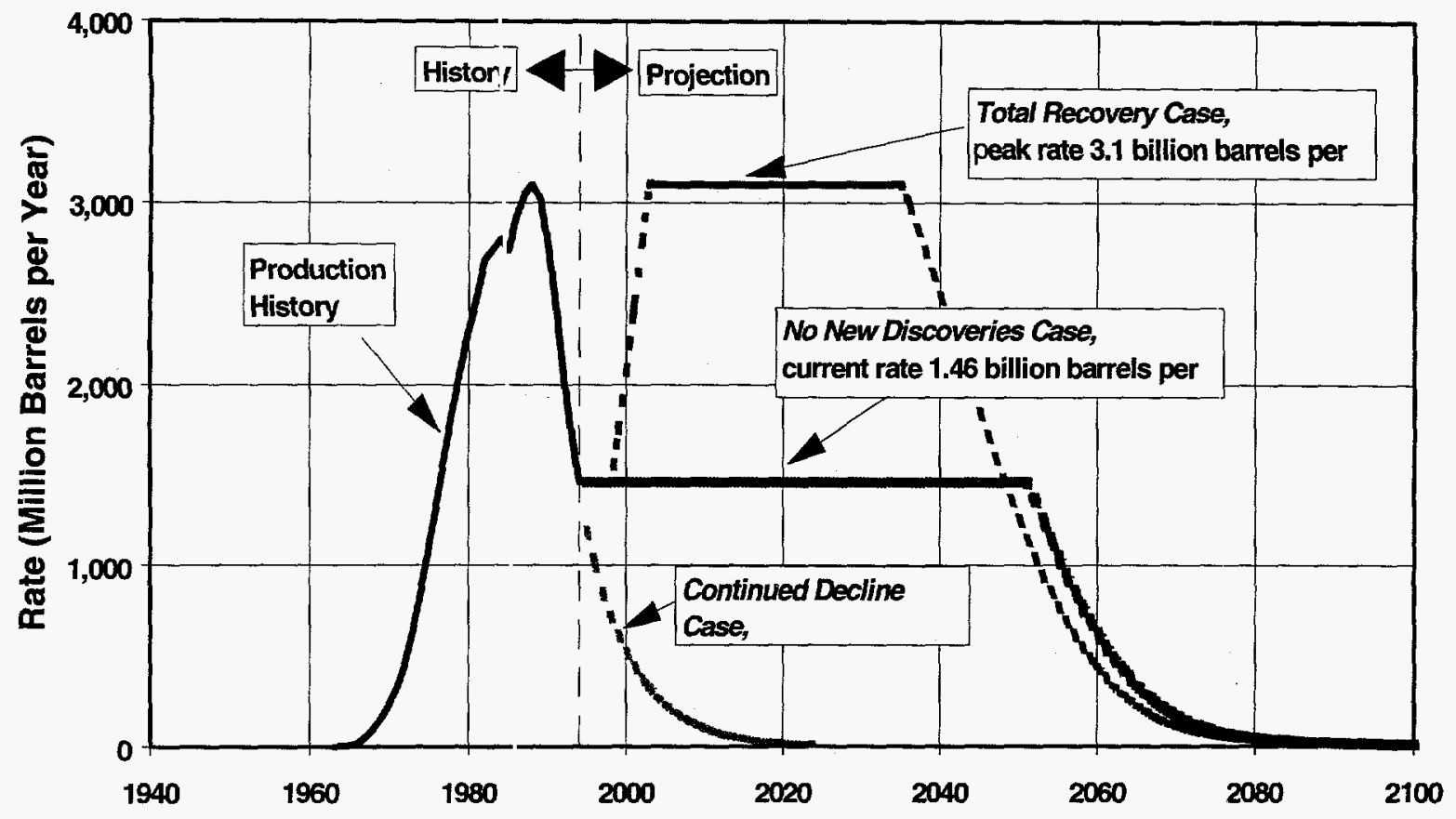

Source: Energy Information Administratior, Office of Oil and Gas.

Figure 10. Projected Cumulative Oil and Condensate Production, West Siberian Basin

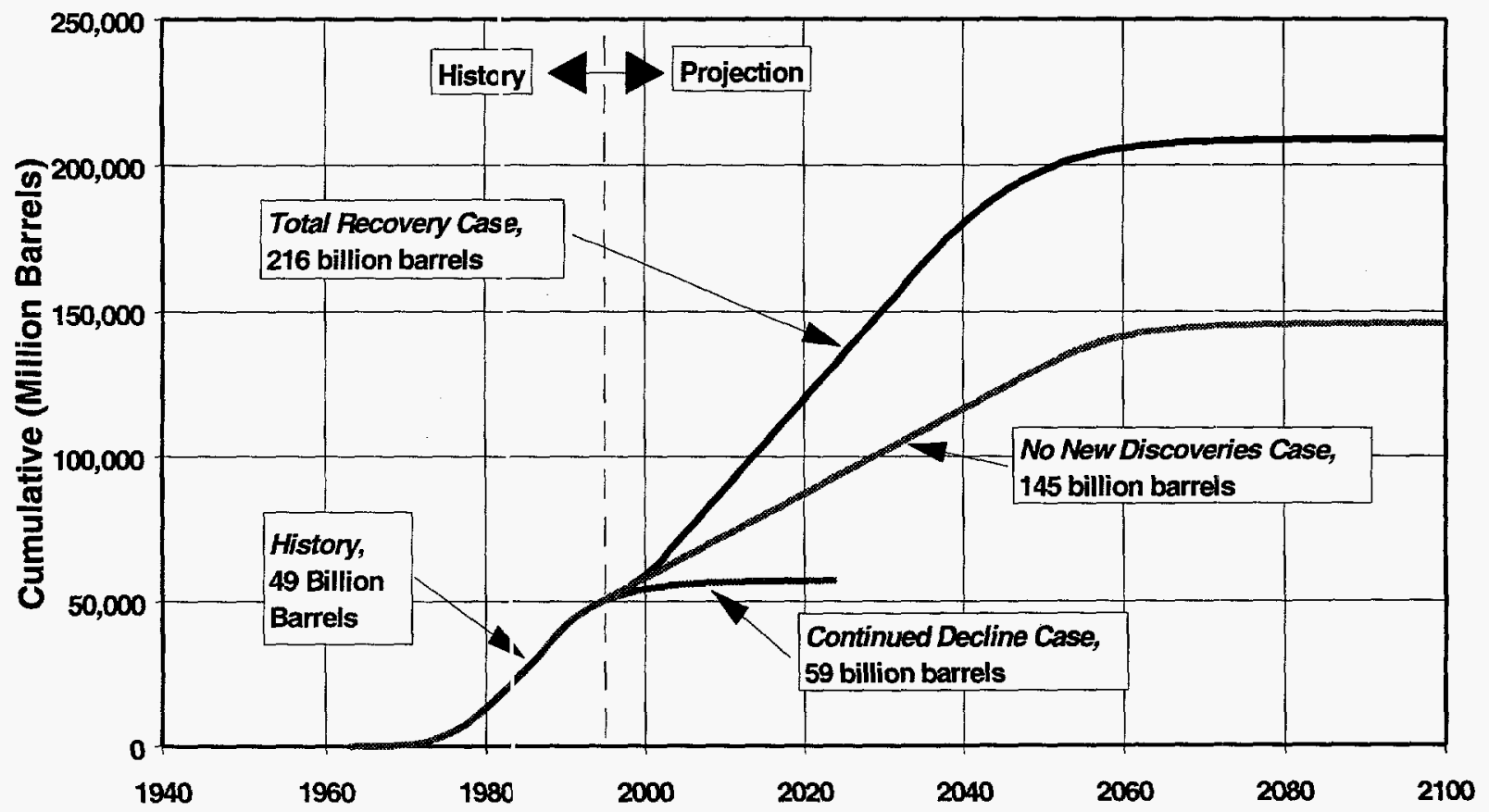

Source: Energy Information Administratior, Office of Oil and Gas. 
The third case (Total Recovery Case) assumes exploration and development return to higher levels and cause production to increase to the historical peak rate of 3.1 billion barrels ( 8.5 million barrels per day) produced in 1988. To reach this peak rate, it is assumed that the current oil production rate would be maintained through the year 1998 and production would then increase over the next five years to the peak rate. Production is then maintained at 3.1 billion barrels per year until the cumulative production plus the amount produced on decline from 3.1 billion barrels per year is equal to the remaining recoverable resource of 167.2 billion barrels. The result is total recovery of 216.5 billion barrels from the basin.

\section{Gas}

Total recoverable gas was estimated to be about 2,189 trillion cubic feet with peak production of approximately 24 trillion cubic feet per year ( 65.8 billion cubic feet per day) in the years 2012 to 2019 (Figure 11). Estimates of gas volume development and production were calculated by using the same method as for oil. The estimates are from the cumulative discoveries curve calculated by using the logistic function and production is based on an assumed decline of the R/P ratio. Gas production has declined since 1992, probably as a result of reduced development activity influenced by the changes that have occurred in Russia since the breakup of the Soviet Union.

Two projections were made to examine potential gas production from the basin. One case (No New Discoveries Case) assumed no additional discoveries and remaining potential of 892 trillion cubic feet, the remaining EUR of the discovered fields. Production was declined at the rate of the theoretical production schedule to depletion in approximately 75 years.

The second case (Total recovery Case) assumed full development of the basin's estimated remaining producible gas of 1,975 trillion cubic feet. The peak historical rate of 20.5 trillion cubic feet per year (56.2 billion cubic feet per day), attained in 1992, was maintained until the cumulative production plus the production from the decline portion of the theoretical projection equaled the total gas resource of the basin of 2,189 trillion cubic feet. In this case, the peak rate could be maintained for 32 years before decline begins (Figures 12 and 13). 


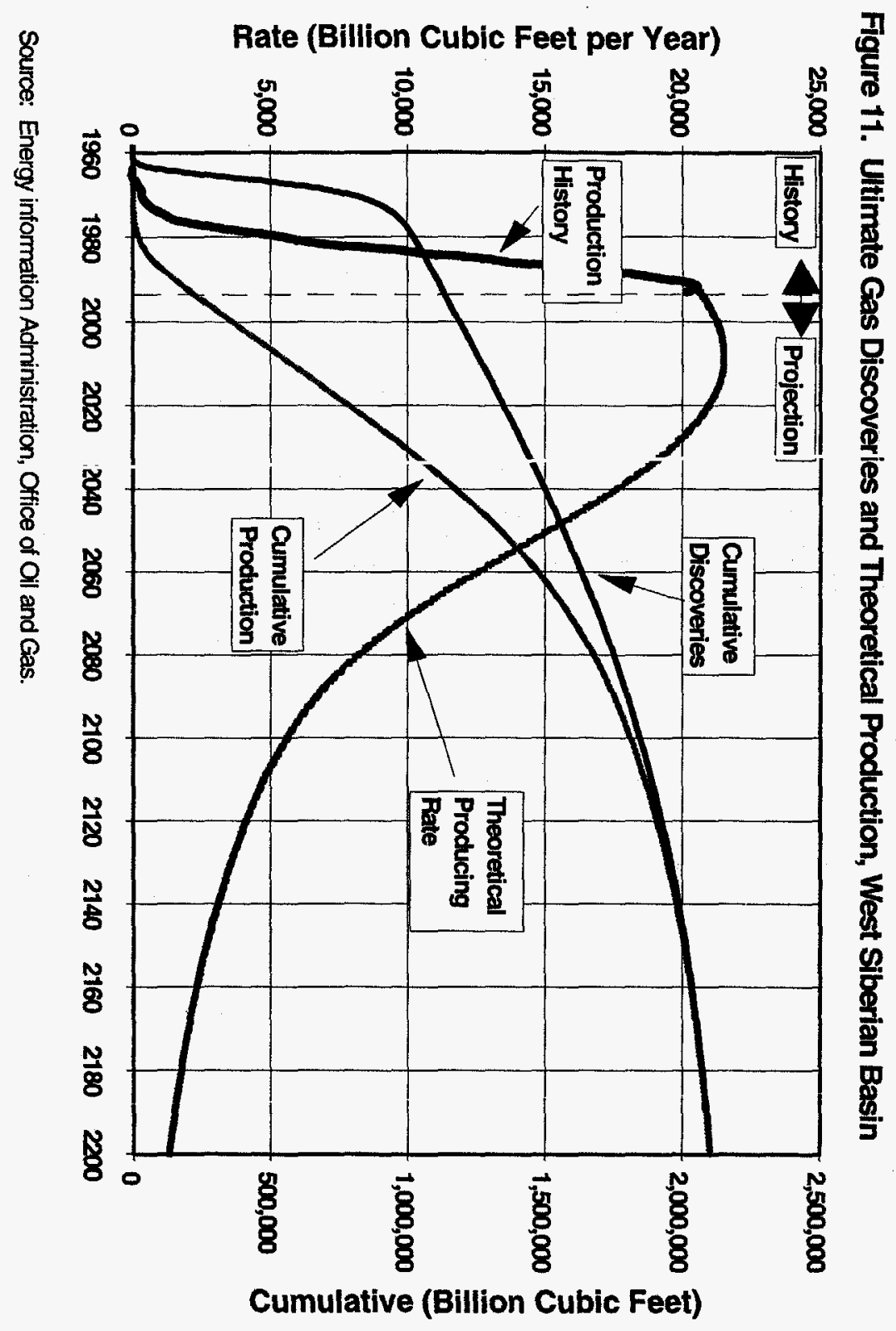



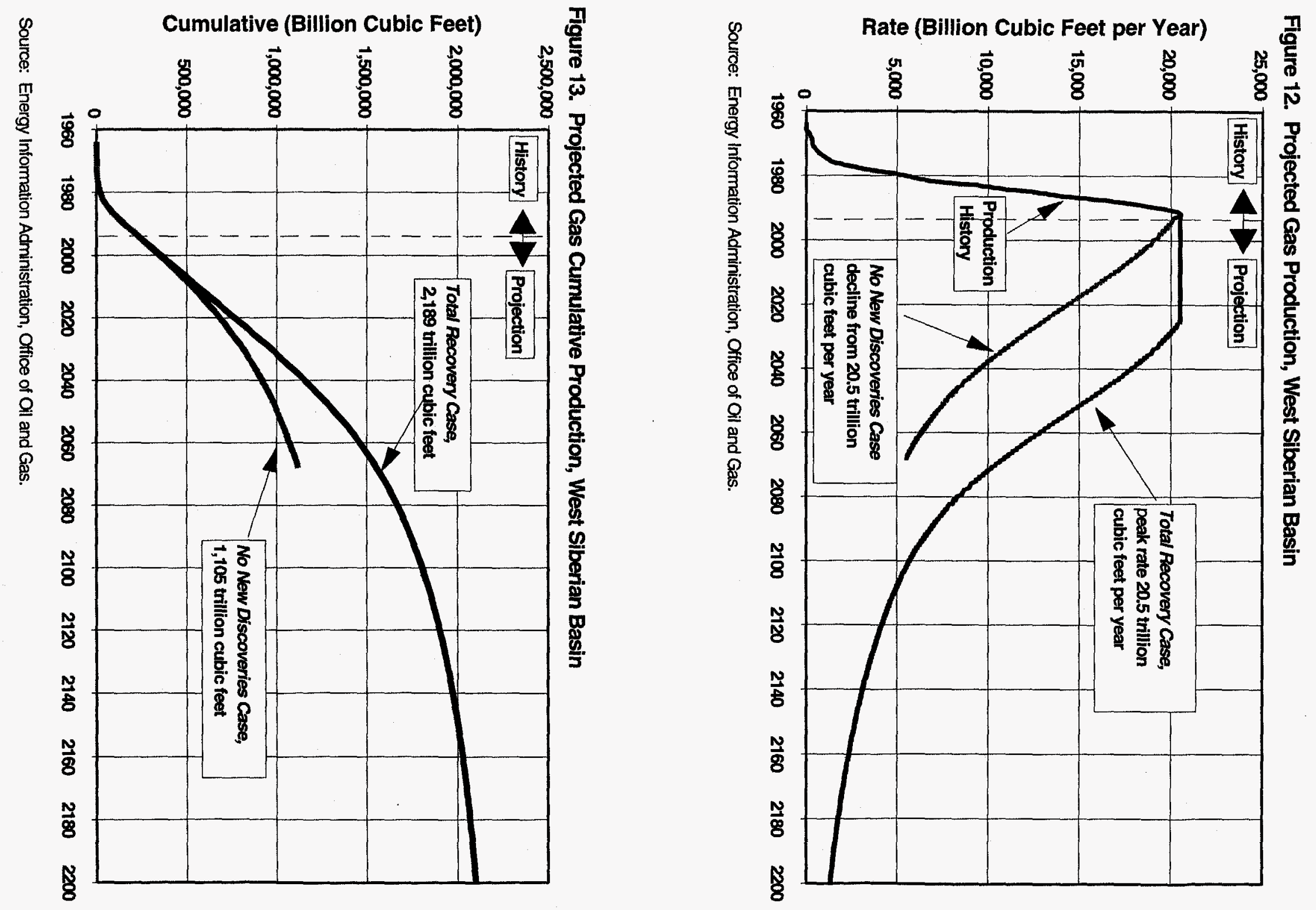


\section{Summary}

The largest oil and gas producing province by area and resources in the former Soviet Union is in western Siberia. The West Siberian Basin is al so one of the largest in the world. The geographic lccation of the basin north of 52 degrees north latitude and the topography of gently sloping lowlands of permafrost and extensive swamps cause significant operational problems.

Oil production from the basin has declined from approximately 3.1 billion barrels in 1988 to 1.5 billion barrels in 1994 (8.5 to 4.1 million barrels per day), and gas production has declined from 22.6 trillion cubic feet of gas in 1991 to 21.9 trillion cubic feet in 1993 (61.9 to 60.0 billion cubic feet per day). Cumulative production was 49.3 billion barrels of oil through 1994 and 214 trillion cubic feet of gas through 1993. Production data by individual field are not complete or reliable; therefore, oil and gas recoveries were calculated by volumetric methods.

A database was constructed containing all available information necessary to calculate reserves volumetrically for 634 oil fields and 147 gas fields witt over 1,500 separate reservoirs. Missing data were imputed based on information from similar or nearty geologic intervals. The estimated ultimate recovery (EUR) was calculated for each reservoir identified as productive and summed to a field totals. The EUR can not be compared to U.S. Reserves that are defined as economically recoverable since economic parameters were not considered in this analysis. The EUR therefore, represents a maximum potential for the basin. To achieve this potential would riquire full development of all identified fields and the application of the latest available technology. Undiscovered resources were estimated by the USGS. The undiscovered volume was added to the estimated ultimate recoverable volumes of individual fields to yield a total basin resource.

Of the 166.1 billion barrels of oil and condensate discovered through 1994, 115.1 billion barrels are in producing fields and 51.0 billion barrels are in fields to be developed. Subtracting the 49.3 billion barrels of production from the EUR of the producing fields yields remaining EUR of 65.8 billion barrels of oil and condensate. Estimated ultimate recovery in undeveloped fields ranges from 30.4 billion barrels of primary oil to 51.0 billion barrels of oil including improved recovery potential.

The mean estimate of the undiscovered oil and condensate is reported as 50.4 billion barrels by the USGS. Estimate of ultimate basin resources is 216.5 billion barrels of oil and condensate with between 146.6 and 167.2 billion barrels remaining to be discovered, developed, and produced after 1994.

The natural gas discovered through 1993 was 1,106 trillion cubic feet. Producing fields contained 765 trillion cubic feet of EUR with nonproducing fields containing 341 trillion cubic feet of EUR to be developed. Remaining recoverable gas is 551 trillion cubic feet in producing fields after subtracting 214 trillion cubic feet of cumulative production. Adding 341 trillion cubic feet in discovered, undeveloped fields sums to 892 trillion cubic feet of remaining, discovered EUR gas. The mean estimate of undiscovered gas resources reported by the USGS is 1,084 trillion cubic feet. The basin's total original gas resources are therefore 2,189 trillion cubic feet with 1,975 trillion cubic feet remaining to be discovered, developed, and produced after 1993.

The average field size in the basin is 248 million barrels of oil or 5.3 trillion cubic feet of gas. The averages are influenced by the very large fields in the basin. The most likely field size is 25 million barrels of oil or 400 billion cubic feet of gas. Economic conditions will influence the development of the smaller fields.

Discovered oil volumes are sufficient to maintain the current production rate of approximately 1.5 billion barrels per year (4.1 million barrels per day) for over 50 years before production begins to decline. If developed, total resources of the basin are sufficient to maintain the historical peak rate of 3.1 billion barrels per year ( 8.5 million barrels per day) for over 35 years before decline begins. Gas production could be maintained for over 30 years at approximately 21 trillion cubic feet per year supported by the remaining gas resources of the basin. 
These production projections are limited scenarios with many variables not considered. However, this analysis shows the potential of the West Siberian Basin as a significant future producer of oil and gas if maintenance and development of the resources continues. The production decline of the past several years is the result of reduced development and maintenance indicating that only a fraction of the potential resources would be recovered if development and exploration in the basin were to cease. 


\section{References}

1. Energy Information Administration, Oil and Gas Resources of the Fergana Basin, DOE/E[A TR/0575 (Washington, DC, January 199:5).

2. Energy Information Administration, International Energy Annual 1995, DOE'EIA0219(95) (Washington, DC, December 1996), p. 6, p. 9 .

3. S. P. Maksimov and others, 1987, Oil and Gas Fields of the USSR [in Russian], (Mosco'N, Nedra, v. 2,303 p.).

4. J.A. Peterson and J.W. Clarke, West Siberian Oil-Gas Province, U. S. Geologic Survey Open-File Report 89-192 (Missoula, Mt. and Reston, VA).

5. D. Muchmore, "Macros Help Solve 'Dommon Petroleum Engineering Calculations," Oil and Gas Journal (November 6, 1995) pp 38-44.

6. Schlumberger Well Services, Log Interpretation Charts (Schlumberger Well Services, 1985)

pp.100-101.
7.American Petroleum Institute, A Statistical Study of Recovery Efficiency, API BUL D14 (Washington, DC, October 1967).

8. G. F. Ulmishek and C. D. Masters, Petroleum Resources in the Former Soviet Union, U. S. Geological Survey Open File Report 93-316, 1993 (Denver, CO and Reston, VA)

9. M. K. Hubbert, U. S. Energy Resources, $A$ Review as of 1972, Serial No. 93-40 (92-72), Part I, 1974 (U. S. Printing Office, Washington DC).

10. Energy Information Administration, Report on the Petroleum Resources of the Federal Republic of Nigeria, DOE/AA-0008 (Washington DC, October 1979).

11. SigmaPlot Scientific Graphing Software, Transforms and Curve Fitting, Revision SPW 1.0 (United States, July 1993). 
Appendix A

Petroleum Geology 


\section{Petroleum Geology}

The petroleum geology discussion is copied from a section of Open-File Report 89-192 of the Department of the Interior, U. S. Geological Survey, West Siberian Oil - Gas Province by James A. Peterson of Missoula, Montana and James W. Clarke of Reston, Virginia
(1989). The page numbers correspond to the page numbering of the EIA report, but figure numbers have not been changed from the original USGS report by Peterson and Clarke. 



\section{PETROLEUM GEOLOGY}

\section{Introduction}

The West Siberian oil-gas province has been subdivided into oilgas regions in various ways by different authors. The subdivision adopted in this report follows that of Maksimov and others (1987) (fig. 56). The oil and gas fields of the entire province are plotted at a small scale on figure 57 , and those of each oil-gas region at a larger scale on figures 58-60.

The basin has four major productive areas based on age of the reservoir rocks, type of trap, and kind of hydrocarbons produced. These are 1) the Middle $O b, 2$ ) Near-Ural, 3) Southern Basin, and 4) Northern Basin.

Middle-Ob (includes the Middle ob region of figure 56) - Most of the production in this area is oil from Lower Cretaceous clastic rocks, mainly in anticlinal traps within a deltaic-marine transitional sedimentary complex. Stratigraphic trapping is also a major component of the trapping mechanisms. Two large regional uplifts dominate this area, the Surgut and Nizhnevartov arches (fig. 18), which yield a major share of the oil produced in the West Siberian basin. The supergiant Samotlor field and other supergiant oil fields are located in this area.

Near-Ural (includes the Near-Ural and Frolov regions of figure 56) Production in the Near-Ural region in the western part of the basin is primarily from Upper Jurassic clastic rocks; there is some production also from Lower Cretaceous clastic reservoirs and some from weathered basement. The trapping mechanism is paleostructural-stratigraphic; reservoir rocks pinch out against high-standing basement rocks. The Near-Ural area is mainly oil-productive in the south and gas-productive in the north.

Southern Basin (includes the Kaymysov, Vasyugan, and Paydugin regions of of figure 56) - Most of the production here is oil and oil-gas from Jurassic clastic reservoirs mainly on anticlines or arches inherited from basement highs. Some production also is obtained from middle and upper Paleozoic carbonate reservoirs.

Northern Basin (comprises the Yamal, Gyda, Nadym-Pur, and Pur-Taz regions of figure 56) - Gas and gas-condensate are produced from mainly Upper Cretaceous (Cenomanian) clastic rocks on anticlinal traps. Urengoy, the world's largest gas field, and several other supergiant gas fields are located in this area.

In general, the timing of trap development was somewhat different for these four major productive areas. In most of the basin, uplifted basement blocks were present prior to the deposition of the Jurassic and Cretaceous reservoir rocks. In the Near-Ural and southern basin areas, Jurassic reservoirs commonly pinch out against these blocks. In the northern basin area, the paleostructural traps probably formed early in 


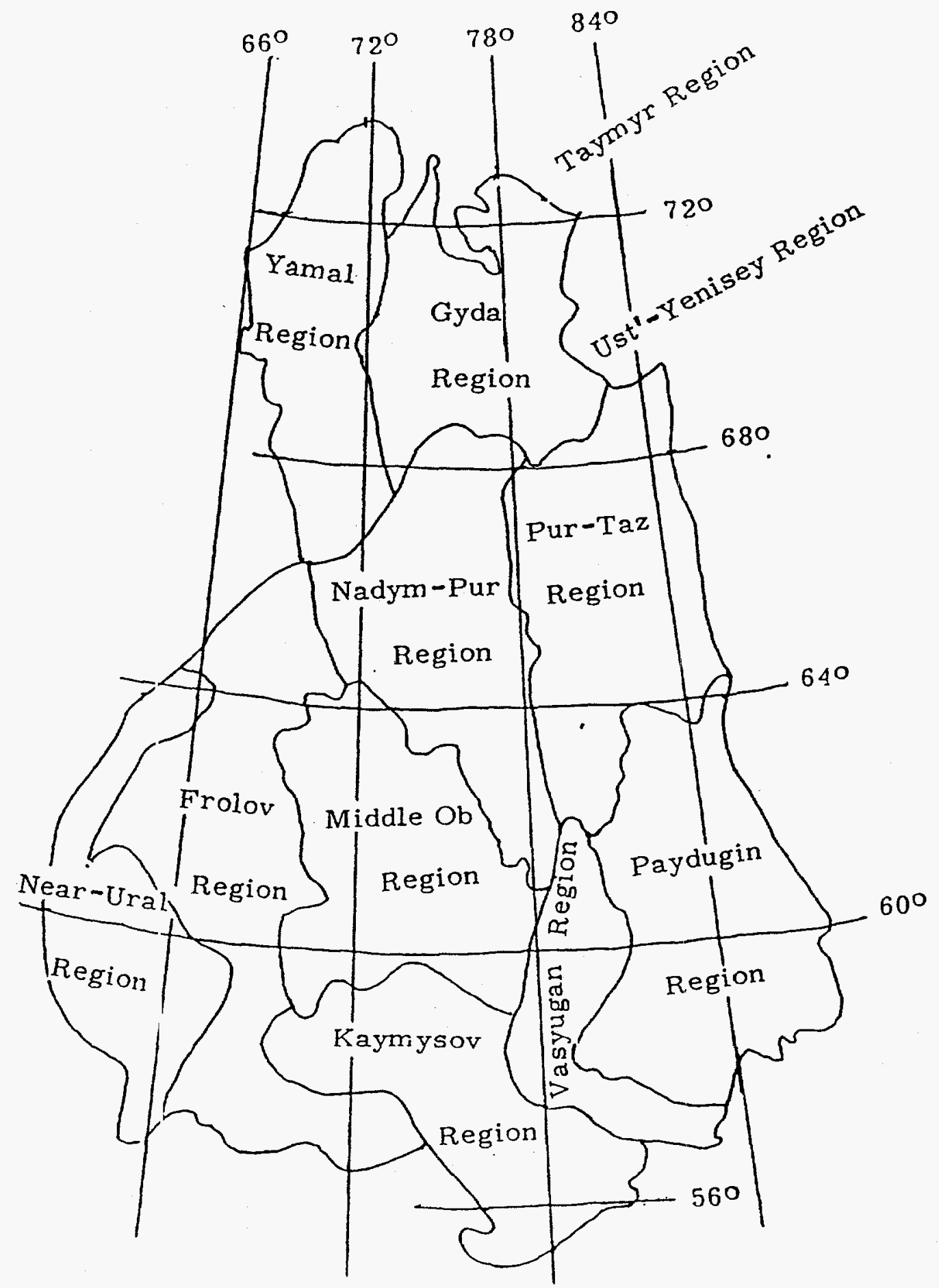

$\underbrace{0300}_{\text {Kilometers }}$

Figure 56

Figure 56. Petroleum regions of the West siberian basin (from Maksimov and others, 1987) 

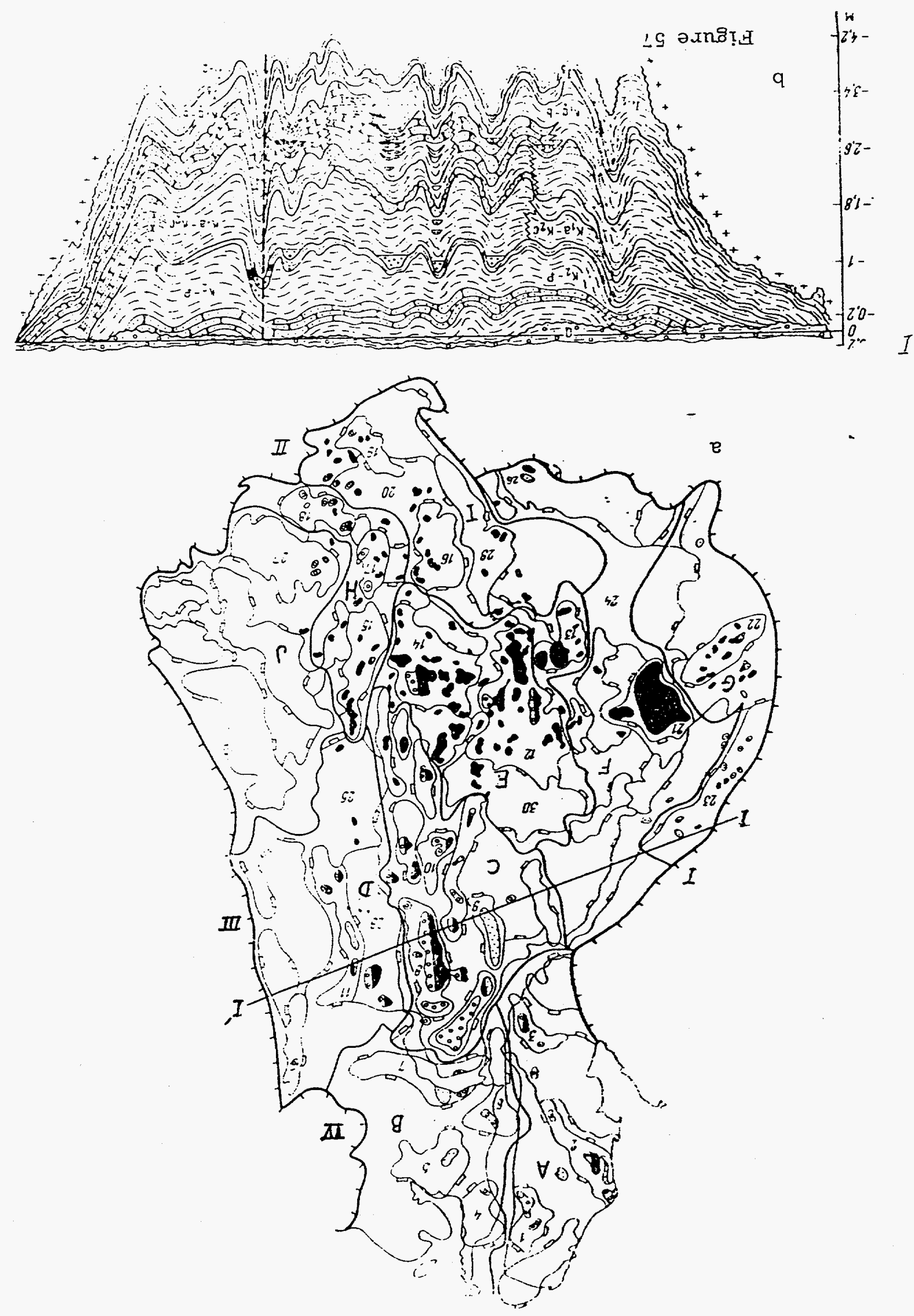
Figure 57. West Siberian oil-gas province if from Maksimov and others, 1987)

a-Schematic map, b-乡ieologic profile.

Very large tectonic features:I-Ural fold belt, II- Kazakh shield, III-Siberian craton, IV-Yenisey-Khatanga mega-downwarp. Large tectonic features: 1-Sredneyamal arch, 2-Nurmin mega-arch, 3-Yuzhno-Yamal mega-arch, 4-Yurats arch, 5-Gydiz arch, 6-Napalkov mega-arch, 7-Nizhnemessoyakha, mega-arch, 8- Urengoy mega-arch, 9-Medvezh mega-arch, 10-Severnyy arch, 11-Russko-Chasiel mega-arch, 12-Surgut arch, 13-Salym arch, 14-Nizhnevartov arch, 15-Aleksandrov mega-arch, 16-Katmysov arch, 17-Srednevasyugan me:ga-arch, 18-Pudin mega-arch, 19-Mezhov mega-arch, 20-Nyurol depression, 21-Krasnoleninsk arch, 22-Shaim mega-arch, 23-Berezovo monocline, 24-Khanty-Mansiysk depression, 25-Kharampur monocline, 26-Bol'sheuk monocline, 27-Parabel mega-arch, 28-Khadyr'Yakhin monocline, 29-J Jem'yan mega-arch, 30-Severo-Surgut monocline. Oil-gas regions: A-Yamal, B-Gyda, C-Nadym-Pur, D-Pur-Taz, E-Middle Ob, F-Frolov, G-Near-Ural, H-Vasyugan, I-Kaymysov, J-Paydugin. 

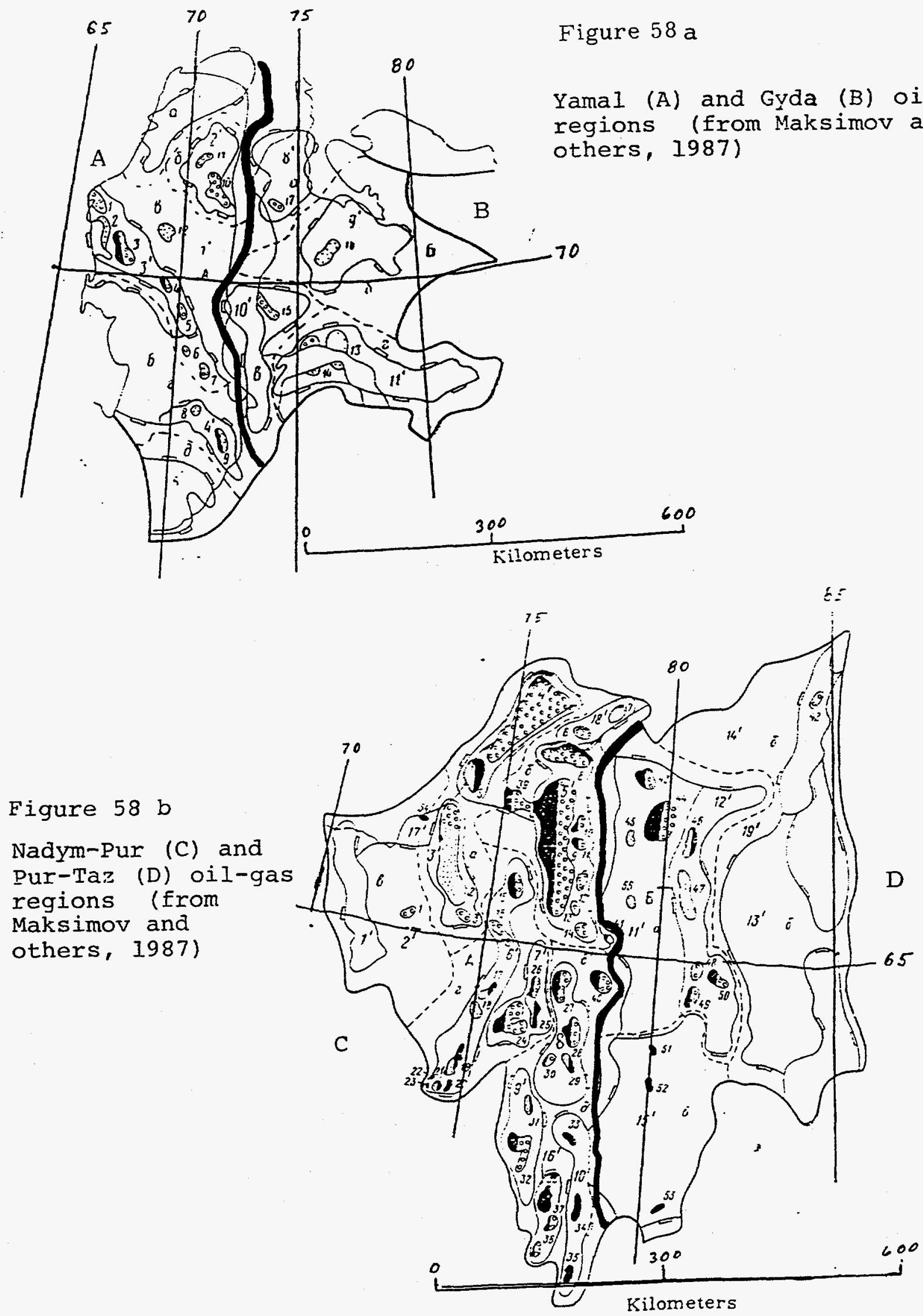
Figure 58a Fields of Yamal oil-gas region (A) and Gyda gas region (B) (from Maksimov and others, 1987).

Large tectonic features: 1'-Severo-Yamal mega-arch, 2'-Sredneyamal arch,

$3^{\prime}$-Nurmin mega-arch, 4'-Yuzhno-Yamal mega-arch, 5'-Shuch'yan high, $6^{\prime}$-Yuribey monocline, $7^{\prime}$-Olen'ya saddle, 8'-Yurats saddle, 9'-Gyda arch, $10^{\prime}$-Napalkov mega-arch, 11'-Nizhnemassoyakha mega-arch.

Oil-gas areas. Yamal oil-gas region: a-Malygin prospective gas-oil area, b-Tambey gas area, c-Nurmin gas-oil area, d-Yuzhno-Yamal oil-gas area, e-Shuch'in porspective oil-gas area. Gyda gas region: a-Severo-Gyda gas area, b-Gyda gas area, c-Napalkov gas area, d-Messov gas area.

Fields: 1-Kharasavey, 2-Kruzenshtern and Yuzhno-Kruzenshtern, 3-Bovanenkov, 4-Neytin, 5-Arkticheskoye, 6-Nurmin, 7-Sredneyamal, 8-Maloyamal, 9-Novoportov, 10-Yuzhno-Tambey, 11-Severo-Tambey, 12-Verhkneteutey, 13-Antipayutin, 14-Semakov, 15-Geofizicheskoye, 16-Gyda, 17-Utren.

Figure 58b. Fields of Ne.dym-Pur oil-gas region ( $C$ ) and Pur-Taz oil-gas region (D) (from Maksimov and others, 1987).

Large tectonic features: l'-Yarudey mega-arch, 2'-Tanlov depression, 3'- Medvezh mega-arch, 4'- Yamburg mega-arch, 5'-Urengoy mega-arch, 6'-Tanlov mega-arch, 7'.- Severnyy arch, 8'-Verkhnepur mega-arch, 9'-Vengapur mega-arch, 10-Var'yegan-Tagrin mega-arch, 11'-Khadyr'Yakhin monocline, $12^{\prime}$-Russko-Chasel mega-arch, 13'-Krasnosel'kup megaarch, 14'-Bol'shekhet depression, 15'-Kharampur monocline, 16'-Ver'yegan

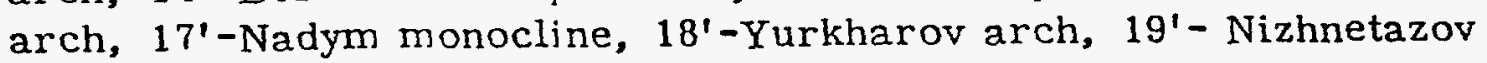
mega-downwarp.

Oil-gas areas. Nadym-Fur oil-gas region: a-Nadym, b-Urengoy, c-Yarudey, d-Gubkin, e-Vengapur. Pur-Tazov oil-gas region: a-Tazov, b-Sidorov, c-Tol'kin.

Fields: 1-Nadym, 2-Medrezh and Nydin, 3-Pangodin, 4-Yamburg, 5-Kharvutin, 6-Yurkharov, 7-Nakhodkin, 8-Severo-Urengoy, 9-Urengoy and Yen"yakhin, 10-Samburg, 11-Yuzhno-Samburg, 12-Vostochnoye Urengoy, 13-Yevo-Yakhin, 14-Pyrey, 15-Yubiley, 16-Yamsovey, 17-Severo-Komsomol, 18-Verkhnepurpey, 19-Muravlenko, 20-Pul'p lyakh, 21-Surtomon, 22-Krayneye, 23-VostochnoPyakutin, 24-Komsomol, 25-Gubkin, 26-Severo-Gubkin, 27-ZapadnoTarkosalin, 28-Tarasov, 29-Yetypur, 30-Vengayakhin, 31-Novogodneye. 32-Vengapur and Yuzhno-Vengapur, 33-Yarayner, 34-Tagrin, 35-Novomolodezh, 36-Severo-Var'yegan, 37-Var'yegan and Zapadno-Var'yegan, 38-Van'yegan. 39-Pestsov, 40-Vostochno-Tarkosalin, 41-Yuzhno-Pyrey, 42-Suzun, 43-Tazov and Vostochno-'Tazov, 44-Zapolyar, 45-Zapadno-Zapolyar, 46-Russkoye, 47-Yuzhno-Russkoye, 48-Kyn, 49-Verkhnechasel, 50-Ust'-Chasel, 51-Kharimpur, 52-Yuzhno-Kharampur, 53-Verkhnekolik"yegan, 54-Sandibin, 55-Beregov. 


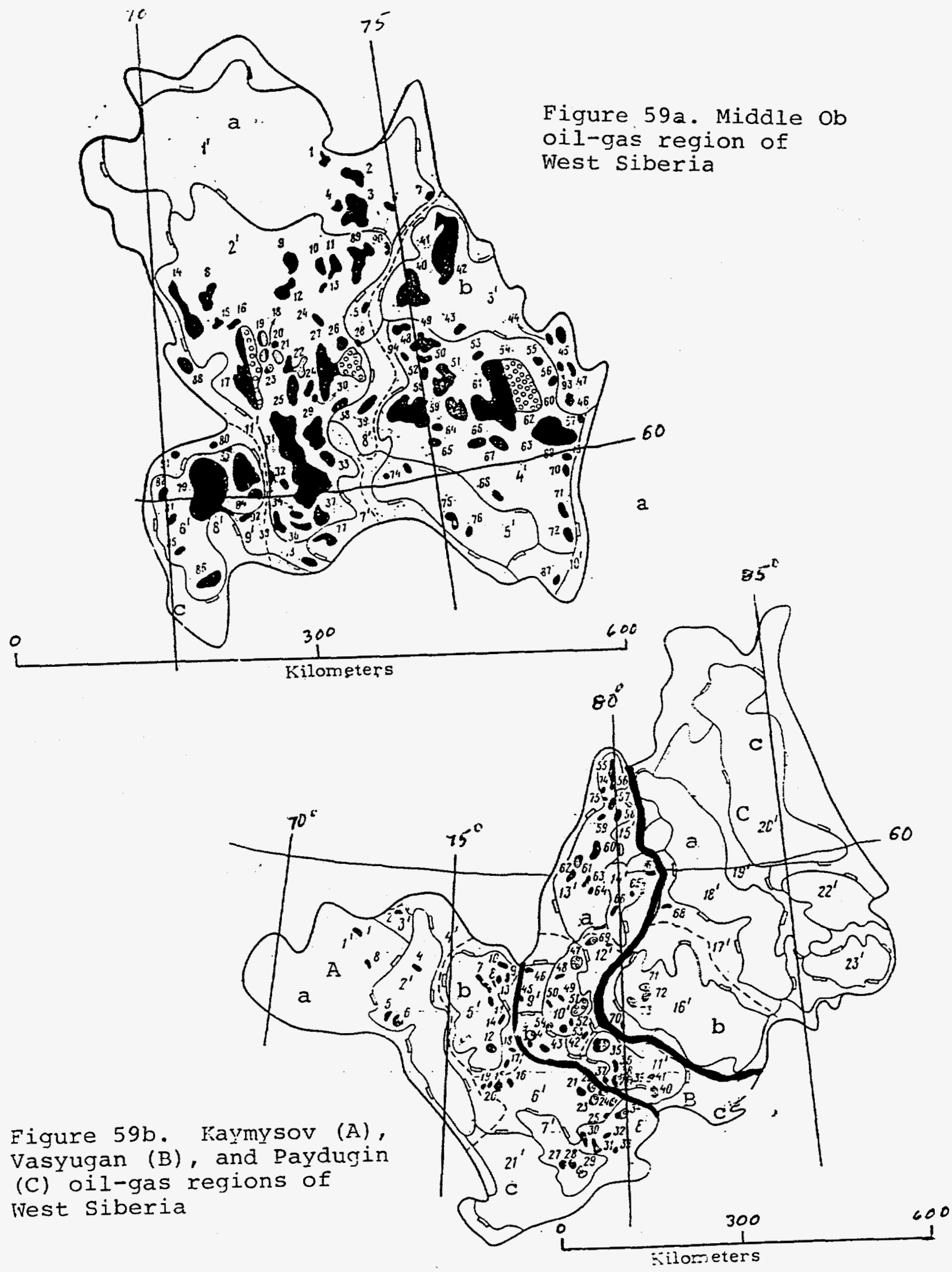


Figure. 59a Fields of Middle Ob region (from Maksimov and others, 1987).

Large tectonic features: 1'-Severo-Surgut monocline, 2'-Surgut arch, $3^{\prime}$-Severo-Vartov monocline, 4'-Nizhnevartov arch, 5'-Yuzhno-Vartov monocline, 6'-Salym arch, $7^{\prime}$-Yugan depression, 8'-Yarsomov mega-downwarp, $9^{\prime}$-Chupal saddle, 10'-Koltogor mega-downwarp, $11^{\text {t}}$-Tundrin depression.

Oil-gas areas:a-Surgut, b-Vartov, c-Salym.

Fields: 1-Severo-Soinllor, 2-Karamov, 3-Kholmogor, 4-Ikilor, 5-Vostochno-Yagun, $\epsilon_{-}$- Pogranich, 7-Byintoy, 8-Nizhnesortym, 9-Kochëv, 10-Tewlin, 11-Kogolym, 12-Konitlor, 13-Sorym, 14-Aypym, 15-Kamyn, 16-Alekhin, 17-Lyantor, 18-Taybin, 19-Tutlín, 20-Kar'yaun, 21-Vachim and Taplor, 22-Minchimkin and Severo-Minchimkin, 23-Saporkin, 24-Russkin, 25-Vystrin, 26-Savuy, 27-Fedorovo, 28-Raven 29-Zapadno-Surgut, Yaunlor, 30-Vershin, 31-Mamontovo, Ust'-Balyk 32-Teplov, 33-Yuzhno-Surgut, Saygatin, 34-Yuzhno-Balyk, 35-Malobalyk, 36-Srednebalyk, 37-Maysk, 38-Vostochno-Surgut, 39-Shirokov, 40-Vat'yegansk, 41-Povkhov, 42-Bol'shekotukhtin, 43-Kurragan, 44-Gun'yegan, 45-Tyumen, 46-Pylin, 47-Yershov, 48-Non'yegan, 49-Pokachev and Severo-Pokachev, 50-Yuzhno-Pokachev, 51-Yur'yev, Potoch, and Severo-Potoch, 52-Las"yegan, 53-Agan, 54-Bol'shectiernogor, 55-Malochernogor, 56-Sorom 57-Strezhev, 58-Lokosov, Pokamasıv, and Chimpas, 59-Severo-Pokur, 60-Samatlor, Megion, and Mykhpay, 61-Vatinsk, 62-Nizhnevartov, 63-Sovetsk, 64-SeveroOstrov, 65-Ostrov, 66-Orekhov, 67-Yermakov, 68-Nezhdan, 69-VartovSosnin, 70-Alenkin, 71-Kvartov, 72-Motyushkin, 73-Malorechen, 74-Novopokur, 75-Maloyugan, 76-Achinov, 77-Severo-Chupal, 78-Chupal, 79-Salym and Severo-Salym, 80-Tundrin, 81-Sredneshapshin, 82-Verkhneshapshin, 83-Pravdin, 84-Srednesalym, 85-Nizhneshapshin, 86-Verkhnesalym, 87-Ledov, 88-Studenoye, 89-Yuzhno-Yagun, 90-Grib, 91-Priob, 92-Petelin, 93-Ruf'yegan, 94-Nivagal. 
Figure 59b. Fields of Kaymtsov oil-gas region (A), Vasyugan oil-gas region (B), and Paydugin oil-gas region (C) (from Maksimov and others, 1987).

Large tectonic features: $1^{\prime}$-Khanty-Mansiysk depression, 2'-Dem'yan mega-arch, 3'-Chupal saddle, 4'-Yugan depression, 5'-Kaymysov arch, $6^{\prime}$-Nyurol depression, 7'-Mezhov mega-arch, 8'-Verkhnetar monocline, $9^{\prime}$-Lomov saddle, 10'-Srednevasyugan mega-arch, 11'-Pudin mega-arch 12'-Olen saddle, 13'-Aleksandrov mega-arch, 14'-Okunev saddle, 15'-Lar'yak mega-downwarp, 16'-Parabel mega-arch, 17'-Ust'-Tym depression, 18'-Pyl'-Karamin mega-arch, 19'-Korlikov mega-downwarp, 20'-Karal'kin mega-arch, 21'-Tar monocline, 22'-Tym mega-arch, $23^{\prime}$-Vladimir arch.

Oil-gas areas. Kaymysov oil-gas region: a-Dem'yan, b-Kaymyson, c-Mezhov. Vasyugan oil-gas region: a-Aleksandrov, b-Vasyugan, c-Pudin. Paydugin oil-gas region: a-Paydugin, b-Sil'gin.

Fields: 1-Tukan, 2-Multanov, 3-A yyrun, 4-Taylakov, 5-Urnen, 6-Usanov, 7-Pervomay, 8-Katyl'gin, 9-Ozer, 10-Olen'ye, 11-Lontyn'yakh, 12-Moiseyev, 13-Zapadno-Katyl'gin, 14-Poselkov, 15-Igol, 16-Talov, 17-Pon'zhev, 18-Glukhov, 19-Karay, 20-Zapadno-Karay, 21-Urman, 22-Gerasimov, 23-Nizhnetabagan, 24-Severo-Kalinov, 25-Kalinov, 26-Yuzhno-Tabagan, 27-Mezhov, 28-Vostochno-Mezhov, 29-Veselov, 30-Maloich, 31-Verkh-Tar, 32-Rakitin, 33-Tay-Das, 34-Kazan, 35-Luginets, 36-Severo-Ostanin, 37-Zapadno-Ostanin, 38-Ostanin, 39-Mirnoye, 40-Verkhnekambar, 41-Selimkhanov, 42-Shingin, 43-Festival, 44-Chvorov, 45-Yuzhno-Cheremshan, 46-Lomov, 47-Severo-Vasyugan, 48-Srednevasyugan, 49-Srednenyurol, 50-Klyuchev, 51-Myl'zhinsk, 52-Yuzhno-Myl'zhinsk, 53-Verkhnesalat, 54-Rechnoye, 55-Severo-Siktor, 56-Severo-Khokhryakov, 57-Khokhryakov, 58-Permyakov, 59-Kolik"yegan, 60-Vakh, Severo-Vakh, and Yuzhno-Vakh, 61-Severnoye, 62-Protoch, 63-Chebach'ye, 64-Kondakov, 65-Vartov, 66-Nikol, 67-Liney, 68-Kiyev"yegan, 69-Chkalov, 70-Sobolinoye, 71-Severo-Sil'gin, 72-Ust'-Sil'gin, 73-Srednesil'gin, 74-Vonter, 75-Enitor. 


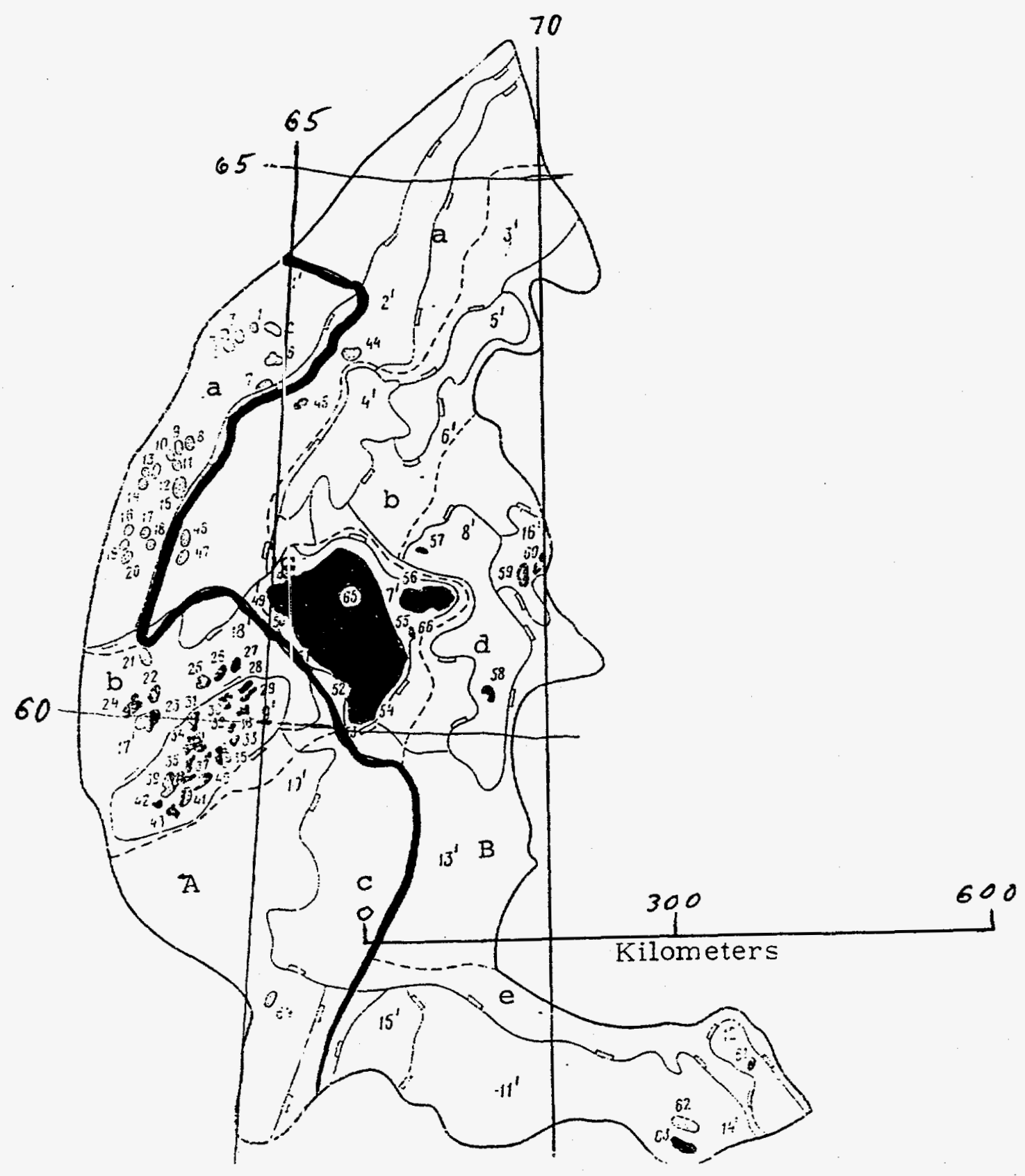

Figure 60. Near-Ural (A) and Frolov

(B) oil-gas regions of West Siberia 
Figure 60. Fields of Near-Ural oil-gas region (A) and of Frolov oil-gas region (B) (from Maksimov and others, 1987).

Large tectonic features: $1^{\prime}$-Berezovo monocline, 2'-Verkhnepoluy monocline, 3'-Nadym depression, 4'-Pomut mega-arch, $5^{\prime}$-Yuil saddle, $6^{\prime}$-Vynglor depression, $7^{\prime}-\mathrm{K}$ rasnoleninsk arch, 8'-Zapadno-Lyamin mega-arch, 9'-Shaim mega-arch, 10'-Vostochno-Turin monocline, 11'-Turtas monocline, $12^{\prime}$-Pologrudov mega-arch, 13'-Khanty-Mansiysk depression, $14^{\prime}-$ Bol $^{\prime}$ sheuk monocline, $15^{\prime}$-Tobol mega-arch, 16'-Gornoye, 17'-Verkhnekondin mega-downwarp, 18'-Sherkalin mega-downwarp.

Oil-gas areas. Near-Ural oil-gas region: a-Berezovo gas area, b-Shaim oil area, c-Karabash gas area. Frolov oil-gas region: a-Kazym gas area, b-Yuil prospective gas area, c-Krasnoleninsk oil area, d-Lyamin oil area, e-Tobol oil-gas area.

Fields: 1-Severo-Alyasov, 2-Pokhrom, 3-Yuzhno-Alyasov, 4-Demin, 5-Berezovo, 6-Chuel, 7-Tugiyan, 8-Severo-Igrim, 9-Yuzhno-Igrim, 10-Paul'Tur, 11-Nulin-Tur, 12-Vostochno-Syskonsyn'in, 13-ZapadnoSyskonsyn'in, 14-Yuzhno-Syskonsyn' in, 15-Pungin, 16-Gornoye, 17-Zapadno-Shukhtungort, 18-Vostoshno-Shukhtungort, 19-Zapadno-Ozer, 20-Vostochno-Ozer, 21-Verkhnekondin, 22-Verkhnelem'in, 23-Danilov, 24-Lem'in, 25-Zapadno-Lovin, 26-Lovin, 27-Yakhlin, 28-Severo-Potanay, 29-Yuzhno-Potanay, 30-Zapadno-Kartop'in, 31-Filippov, 32-Kayumov, 33-Vostochno-Semividov, 34-Severo-Ubin, Zapadno-Ubin, Maloubin, and Yuzhno_ubin, 35-Srednemulym'in, 36-Tolumsko-Semividov, Yuzhno-Tolum, Vostochno-Tolum, 37-Severo-Tolum, 38-Kartop'ya-Okhan, 39-SeveroMortym'in, Zapadno-Mortym'in, Mortym'in-Teterev, Severo-Teterev, Yuzhno-Mortym'in, Severo-Trekhozer, 40-Vostochno-Teterev, 41-Yuzhno-Teterev, 42-Mulym'in, 43-Trekhozer, 44-Severo-Kazym, 45-Lykhmin, 46-Severo-Sote-Yugan, 47-Yuzhno-Sote-Yugan, 48-Sosnovomys, 49-Yem"yegov, 50-Talin, Pal'yanov, 51-Ingin, 52-Lorbin, 53-Kamen, 54-Yelizarov, 55-Novoyendyr, 56-Srednenazym, 57-Aprel, 58-Khanty-Mansiysk, 59-Dekabr, 60-Verkhnalyamin, 61-Taytym, 62-Tevriz, 63-Prirakhtov, 64-Karabash, 65-Lebyazh'ye, 66-Galyanov. 
the Mesozoic and were erhanced by regional uplift in Tertiary time. In the Middle-Ob area, trajss more commonly formed penecontemporaneously with reservoir rock deposition. Differential compaction may also have had a significant role on trap development in most areas. A significant stratigraphic facies aspect is important in reservoir, source rock, and trap development in almost all parts of the basin.

In addition to the main oil-gas occurrence in the Jurassic and Cretaceous fill of the klasin, hydrocarbon pools have been found in several areas in pre-Jurassic (largely Middle and Late Paleozoic) sediments. Flows of oil. have been recovered from such rocks in not less than 12 areas (Trofimuk, 1975), and com-mercial reserves have been proved. These oils are chemically distinct from Mesozoic oils and apparently were generated by Paleozoic sediments (Ryzhkova, 1976; Trofimuk, 1976; Rigassi, 1986). Deep seismic sounding indicates a great thickness of these unmetamorphosed or lightly metamorphosed rocks in several parts of the basin. In the Middle Ob region, they are $3-4 \mathrm{~km}$ $(10,000-13,000 \mathrm{ft})$ thick (Aleksin and others, 1975), and are as much as $5-7 \mathrm{~km}(16,000-23,000 \mathrm{ft})$ thick in other parts of the basin (figs. 12-14, 17, 19).

The West Siberian basin covers an area of approximately $3,500,000$ $\mathrm{km}^{2}\left(1,300,000 \mathrm{mi}^{2}\right)$ and conţains a Mesozoif-Cenozoic basin fill of approximately $16,000,000 \mathrm{~km}^{3}\left(4,000,000 \mathrm{mi}^{3}\right)$, including the South Kara basin area (figs. 9,17). Thickness of the post-Triassic sedimentary cover ranges from $3-4 \mathrm{~km}(10,000-13,000 \mathrm{ft})$ in the central and south to $8-10 \mathrm{~km}(25,000-33,000 \mathrm{ft}$ ) or more in the north (figs. 16, 17 19). The main oil-gas complexes are in clastic sediments of the Jurassic, Neocomian, and Aptian-Cenomanian. Each of these complexes is overlain by thick regional shale deposits of Kimmeridgian-Valanganian, Aptian-Albian, and Turon Lan-Oligocene ages, respectively. The chemistry of the oils indicates that each complex is an independent petroleum unit (Yermakov and Skorobogatuv, 1984). Distribution of the oil and gas areas of the basin appeals to be directly related to the type of organic material present in the different complexes. Thick and widespread source rock units of either the sapropelic or the humic type and mixtures of both are presient in each of the complexes. Additional unexplored potential oil and gas complexes are present in clastic sediments of the Triassic: in the northern region and in the Paleozoicbasement complex of the southern, central, eastern, and western basin areas.

Geothermal gradients in the basin are near normal in most areas (fig. 61). Lowest values $\left(2.8-3.0^{\circ} \mathrm{C}\right.$ per $100 \mathrm{~m}$ ) are in the southeastern part of the basin; highest values (greater than $4.5^{\circ} \mathrm{C}$ per $100 \mathrm{~m}$ ) are in the Near-Urals western region; values of $3.3-4.2^{\circ} \mathrm{C}$ per $100 \mathrm{~m}$ are characteristic of the remainder of the basin (Yermakov and Skorobogatov, 1984). Present-day temperatures at the top of the MiddleUpper Jurassic Tyumen Formation, based on 3,200 wells, range from 30 $50^{\circ} \mathrm{C}$ near the line of pinchout to $100-130^{\circ} \mathrm{C}$ in the central and north parts of the platform (fig. 62). Values at the top of the Neocomian range from $30-60^{\circ} \mathrm{C}$ to $80-100^{\circ} \mathrm{C}$; at top of Cenomanian from $10-20^{\circ} \mathrm{C}$ to 


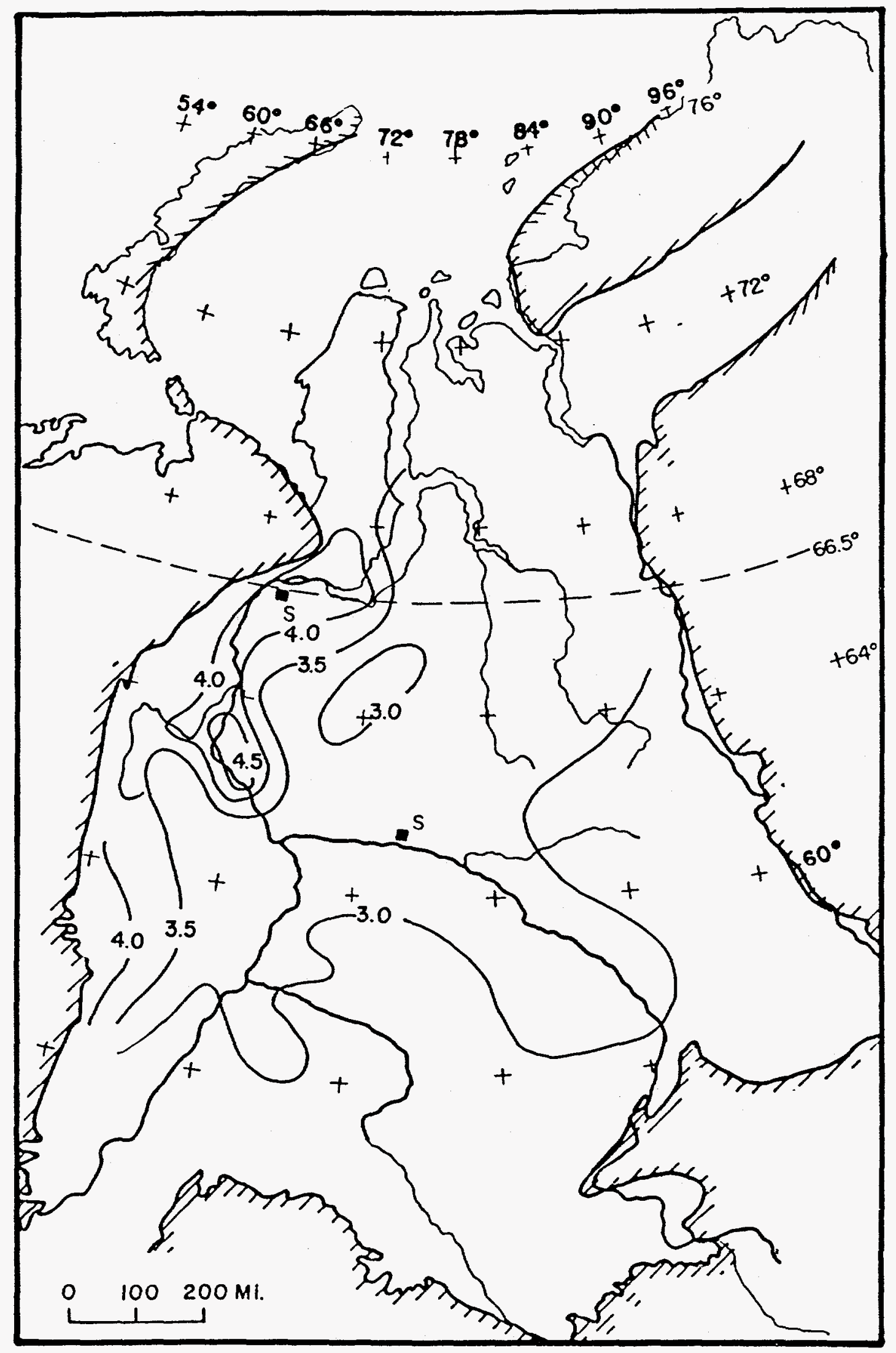

Figure 61. Geothermal gradient, ${ }^{\circ} \mathrm{C} / 100$ m (from Sergivenko, 1973) 


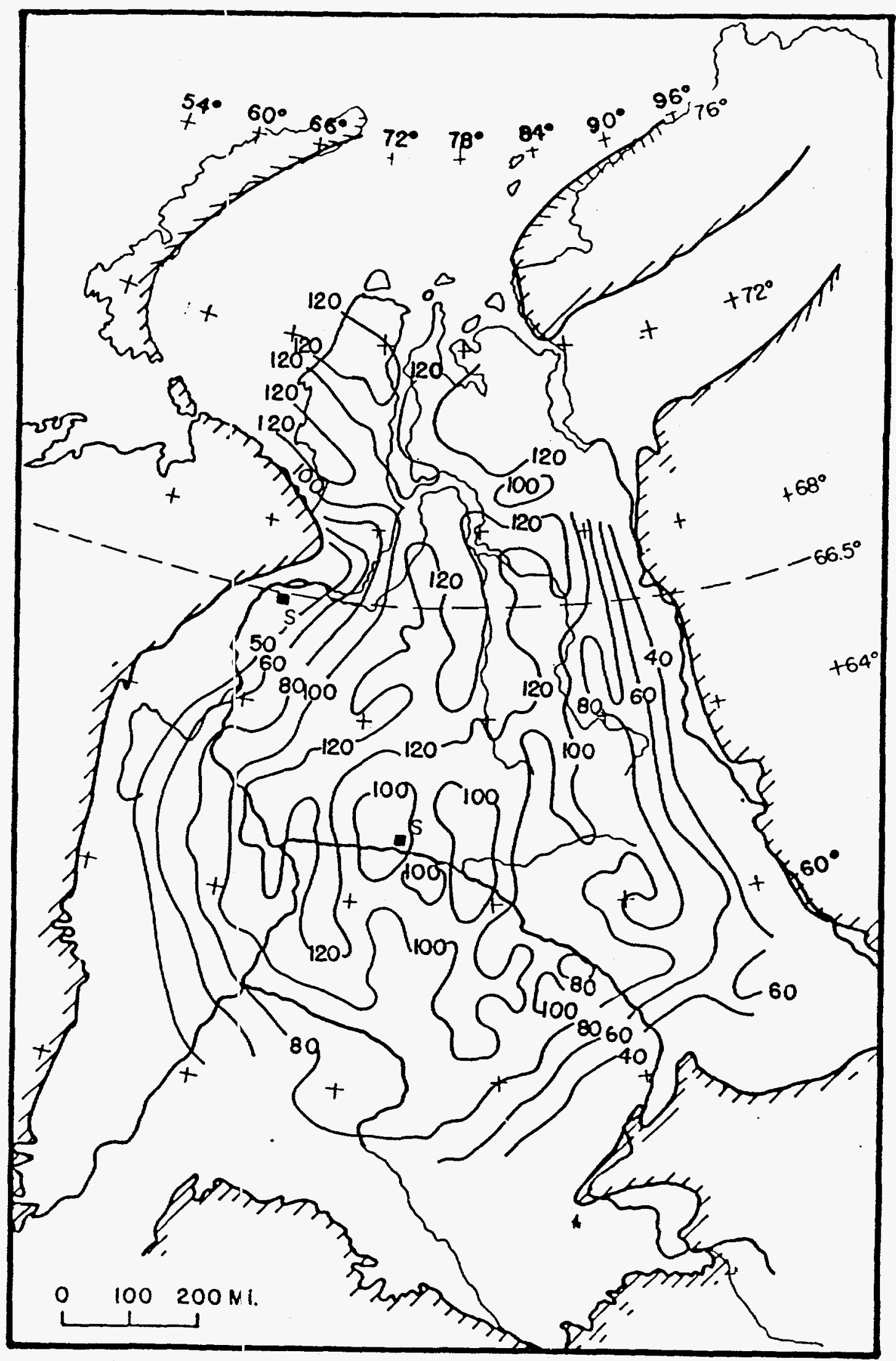

Figure 62. Present-day temperature $\left({ }^{\circ} \mathrm{C}\right)$ at top of Tyurien Formation (Middle-Upper Jurassic) (from vermakov and skorobogatov, 1981) 
$55^{\circ} \mathrm{C}$ (fig. 63). The time of maximum paleotemperature was at the end of the Chegan Stage of the early 0ligocene, after which temperatures began to drop because of regional uplift (Yermakov and Skorobogatov, 1984). Pure gas pools (mainly methane) in Jurassic rocks are found for paleotemperatures below $80^{\circ} \mathrm{C}$, and a variety of oil-gas-condensate accumulations are present in the $80^{\circ}-145^{\circ} \mathrm{C}$ range. Above a paleotemperature of $150^{\circ} \mathrm{C}$, the probability of oil being preserved is much less. No hydrocarbon deposits have yet been found in the West siberian basin where paleotemperatures have exceeded $180^{\circ} \mathrm{C}$ (Yermakov and Skorobogatov, 1984e), although gas and gas-condensate pools are possible above $180^{\circ} \mathrm{C}$.

Regionally, the distribution of oil and gas accumulations in the basin shows a relatively well defined pattern (figs. 56,64). Accumulations of predominantly gas or gas-condensate are found in the Yamal, Gyda, Nadym-Pur, Pur-Taz, northern Near-Ural and Ust-Yenisey regions; predominantly oil is found in the Middle Ob, Frolov, southern Near-Ural and Kaymysov regions; and mixed oil and gas in the Vasyugan and Paydugin regions. Mixed oil and gas are projected for the Taymyr potential oil-gas region (fig. 55).

The following sequence of petroleum generation and accumulation stages has been proposed for the Jurassic sediments (Yermakov and Skorobogatov, 1984; Lugovtsov and Moskvin, 1980):

1. Biogenic gas began to be generated in the Lower-Middle Jurassic sediments in the northern region in Middle Jurassic time. Much of this gas was lost because of lack of seals. The lower parts of the Jurassic section may have already been in the oil window by Late Jurassic time (figs. 17-19).

2. During Early Cretaceous time, the lower part of the Jurassic was involved in oil-gas generation over practically all of the West Siberian platform.

3. After Cenomanian time, the maturation process in the Jurassic sediments probably diminished and a large part of the north basin was at temperatures greater than $145-150^{\circ} \mathrm{C}$.

4. Regional uplift and geothermal reversal in Neogene time caused a drop in reservoir pressures, some gas was released from solution, and the formation of new pools and redistribution of old pools occurred.

\section{Intermediate stage}

The Intermediate Stage as used here consists of pre-Jurassic Paleozoic, weathered basement-surface, and Permian-Triassic-Liassic taphrogenic graben rocks in the basin area south of approximately $64^{\circ} \mathrm{N}$. North of here, Paleozoic rocks become buried too deeply for economic plays at this time, other than possible gas deposits. Marine, lagoonal, and continental Triassic sedimentary rocks are widespread and thicken 


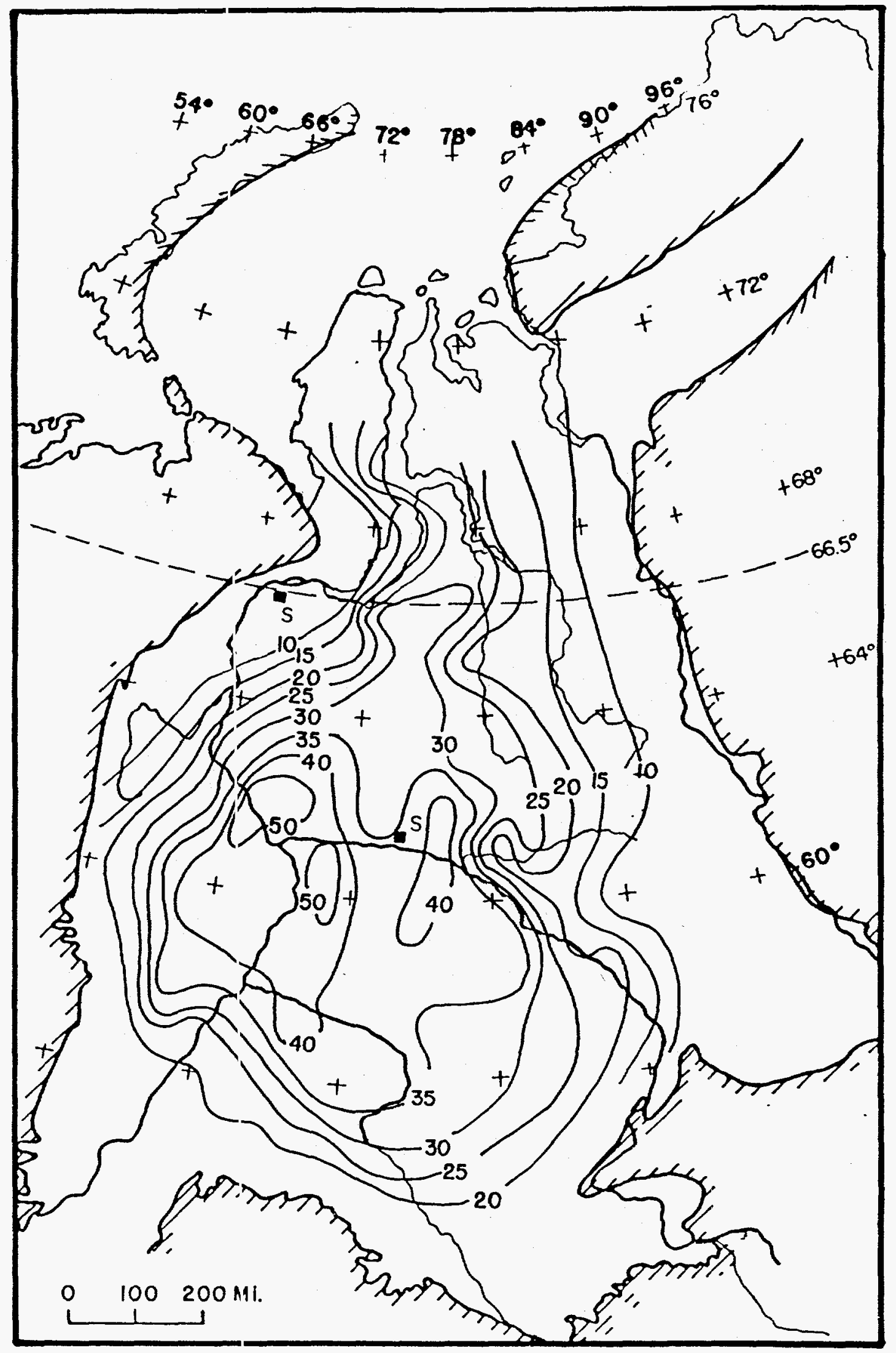

Figure 63. Present-day temperature $\left({ }^{\circ} \mathrm{C}\right)$ near top of Cenomanian (Upper Cretaceous) (after Yermakov and Skorobogatov, 1934) 


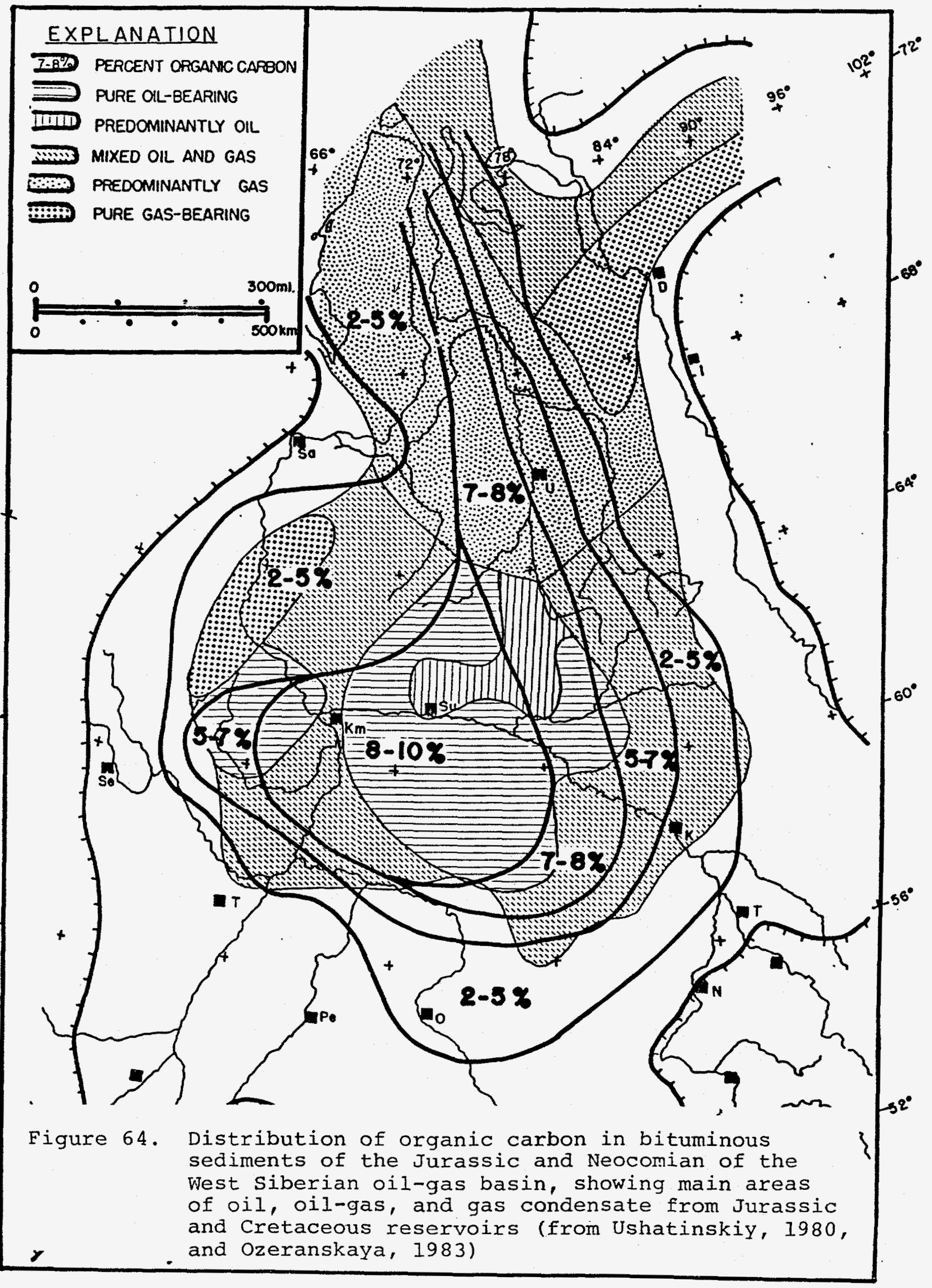


rapidly in the northern area (fig. 20). These rocks are more properly included with the Mesczoic-Cenozoic cover (Zhuravlev, 1984).

The Permian-Triassic-Liassic graben basins are filled with thick deposits of volcanic, volcanogenic-sedimentary, and some alluviallacustrine rocks; these are present in several areas of the Middle Ob and southern areas (figs. $11,17,18,20$ ). These generally are not oil-gas prospective sequences, except as remote possibilities for hydrocarbons migrated into these rocks from post-unconformity Jurassic rocks, or in some cases Paleozoic carbonate or clastic rocks on adjacent uplifts. Petroleum accumulations in these basins are likely to be small and difficult to find.

These rift basins may be more widespread than originally thought. They are commonly not recognized without good deep seismic data. Well control is limited beciuse deeper drilling thus far has generally been for Mesozoic reservoir:s on uplifts rather than in the graben regions. Triassic rocks with vi rinite reflectance indicating paleotemperatures not exceeding the oil vindow have recently been reported along the Irtysh River near Omsk (fig. 17). Matured Carboniferous rocks have been reported to the southwest in the vicinity of Kurgan (Fomin, 1987).

In several parts of the middle and southern areas of the province, oil and gas shows are widespread, and commercial fields have been found in weathered and fractured rocks below the Jurassic unconformity, including Paleozoic reffs and other carbonate rocks. In some cases, particularly on the west side of the basin, accumulations are related to migration and trapping of oil or gas sourced by the overlying Jurassic or Lower Cretaceous organic rich rocks. However, in the southeastern basin area, oil and gas pools are present in Paleozoic carbonate and clastic reservoirs, apparently sourced by high-organic Paleozoic rocks (Ryzhkova, 1976; Trofinuk, 1976; Aleksin and others, 1975; Rigassi, 1986; Vyshemirskiy and others, 1972; Zapivalov and others, 1980; Krylov and others, 1981; and Sevost'yanov, 1980, 1982). Carbonate and clastic rocks of Middle and Late Paleozoic age have been drilled below the Jurassic unconformity in most parts of the central, southern, and eastern areas of the basin, particularly on structurally high areas adjacent to Late Permian-Triassic grabens. Most of these rocks are fractured and metamorphosed to varying degrees, but areas of relatively unaltered rocks also are reported (Krylov and others, 1981; Surkov and others, 1983; Vyshemirsky and others, 1972). A large area of particular interest is the Khanty-Mansiysk depression, where a central massif of Paleozoic age (fig. 13) has been outlined (Surkov, and others, 1983).

According to Sevo:st'yanov (1982), pre-Jurassic structure'is very complex in most of the basin, and oil or gas pools will probably be small. In most areas, ?aleozoic rocks have been over-heated, generally above $160^{\circ} \mathrm{C}$. Two kinds of petroleum accumulations in Paleozoic reservoirs are possible: 1) on pre-Jurassic erosional highs, and 2) within isolated pre-Jurissic reservoirs. Three structural-stratigraphic complexes are recognized in the pre-Jurassic of the central and southern areas of the basin (Sevost'yanov, 1982): 1) a Paleozoic geosynclinal 
complex; 2) a Paleozoic platform zomplex, in the Yenisey-Taz regions; and 3 ) the Triassic-Iiassic taphrogenic complex, found in grabens south of the Triassic blanket cover of the north basin.

According to Zhuravlev (1984), areas of greatest promise for Paleozoic oil or gas include the Nyurol, Khanty-Mansiysk, Yugansk (eastern part), Ust-Tyrreskaya, Nadym (north part), Tanlov, and Yenisey depressions, the develop-ment of which began in the Late Paleozoic and continued through the Triassic or later. Negative factors are as follows: (1) adverse thermal conditions, with high paleotemperatures and the probability that there would be widespread destruction of oils; (2) active tectonism for more than 100 my and widespread magmatic activity; these conditions would cause vertical migration or destruction of earlier oil accumulations; (3) poor reservoir quality in almost all rocks; (4) absence of good seals, such as evaporites and thick clays. Three possible objectives are listed: (1) Middle Paleozoic geosynclinal and platform (to the east) complex - very low potential, except for possibly the Yenisey-Taz block; (2) upper Paleozoic orogenic and platform (to east) complex - some (non-commercial) accumulations of gas and some oil are possible in the troughs in the $O b$ area and some in the Yenisey-Taz block, but it is very difficult to find these troughs; (3) Triassic-Liassic taphrogenic complex within narrow grabens - only non-commercial secondary accumulations of oil and gas may be present, and these will be difficult to find. The overall appraisal is that the intermediate section is poorly prospective.

\section{Platformal Triassic}

The Permian-Triassic taphrogenic rifts extend northward into and across the north basin area (fig. 20). In this area the rift deposits are overlain by thick lagoonal and marine sedimentary rocks, which cover most of the northern part of the basin (Zhuravlev, 1984). These platformal Triassic rocks thicken rapidly northward to more than $2-3$ $\mathrm{km}(6,500-10,000 \mathrm{ft})$, possibly reaching more than $5 \mathrm{~km}(16,000 \mathrm{ft})$ in places (Kontorovich, 1975). These rocks are buried deeply beneath as much as $6 \mathrm{~km}(20,000 \mathrm{ft})$ or more of Jurassic and younger sediments north of the Urengoy-Yamburg region (figs. 15, 16, 17, 19). The 1ithologic nature of the Triassic rocks here is not yet well known. Wells drilled into the Triassic in the north basin have penetrated a section of alternating dark gray shales, siltstones, sandstones, and tuffaceous sandstones (Kontorovich and others, 1975). The presence of a large area of Triassic clastic deposits in the Khatanga downwarp near the Taymyr uplift (fig. 20) (Rudkevich, 1976) suggests that clastic reservoirs, in part marine, should be present to the northeast and perhaps in other parts of the northern region (fig. 20). A relatively thick se'ction of Triassic rocks is identified on seismic sections across the South Kara basin to the northwest. The possibility of good clastic reservoirs and source rocks in the Triassic system of the north basin area appears to be reasonable, although, except for the northeastern region near the Taymyr uplift and in the Khatanga trough, these rocks may be buried in most places to depths within or below the thermal gas window. Good shale seals should be present within and overlying the Triassic beds in 
all of this area, and adequate source rocks should be present in the Triassic marine, lagoonal, and lacustrine beds. According to Yermakov and others (1979), Triassic rocks in the north are definitely favorable for gas.

\section{Jurassic}

Sandstone and siltstone reservoirs of Jurassic age are productive in scores of oil and gas fields in the West Siberian province. Several fields also produce oil from fractured reservoirs of the highly organic, limy sili-ceous, argillaceous Bazhenov Formation. As many as 20 Jurassic pays are identified (Yermakov and Skorobogatov, 1984).

Jurassic rocks tend to be oil-prone, although a large area of gas production is present in the Berezovo area on the west side of the basin, and associated gas is commonly present in many of the oil fields (figs. 65-67). Gas and some oil also have been found in Jurassic sandstone and siltstone reservoirs in a few north basin fields, all of which also produce gas condensate from Cretaceous reservoirs. However, the Jurassic in the north basin area probably has not been heavily explored because of depth constraints in most areas, plus an abundance of already developed ga:s reserves in Cretaceous reservoirs.

Thus far, many more pools have been found in Upper Jurassic reservoirs than in the lower and Middle Jurassic. Three main Upper Jurassic plays are recognized (Skorobogatov, 1980): 1) the Upper Jurassic Vasyugan Formal:ion sandstones; 2) the Vogulkin Formation sandstones and limestones; and 3) the Bazhenov Formation organic-rich, sapropelic, siliceous, l.imy shale. Vasyugan sandstone and siltstone beds are important reservoirs in the southeastern, central and north regions of the basin. The Bazhenov Formation is commonly $10-40 \mathrm{~m}$ (33 $100 \mathrm{ft}$ ) or more thick and is widespread over much of the interior basin. Important production is obtained from fractured reservoirs in this unit in parts of the central basin area, particularly in the Salym and adjacent areas. However, Bazhenov discoveries also have been made in recent years in the Tomsk region (fig. 8), in the north basin area, and in several other areas. Bazhenov reservoirs are fractured and generally over-pressured, particularly in areas of higher temperatures. Many of the associated production problems have not yet been resolved, and partly for this reason the Bazhenov has not been thoroughly explored. However, this unit is potentially one of the most promising future reserve plays of the bas in as technology improves (Skorobogatov, 1984). Horizontal drilling may increase production significantly from the Bazhenov (Izvestiya, January 29, 1986). Promising areas are in the Salym and adjacent region, the Khanty-Mansiysk depression, the northern Middle $O b$ region, and the Yamal Peninsula.

Sandstones of the Jurassic system are moderately high in feldspar content (30-50 percent or more), contain 20-45 percent quartz, and 1-12 percent mica, becoming siomewhat more micaceous in the northern region. Upper Jurassic sandstone reservoirs in the southeast part of the basin are associated mainly with an elongate south-north trend of deltaic and 
Eigure 65 .

\section{Percent}

sandstone, Lower and

Middle Jurassic rocks

showing areas of

predominantly sapropelic

organic matter, and

general distribution of

oil and gas fields

producing from Lower

and iddle Jurassic

reservoirs (from

Nesterov, 1976, Ronkinä

and Bro, 1984). Arrows

show direction of

transport

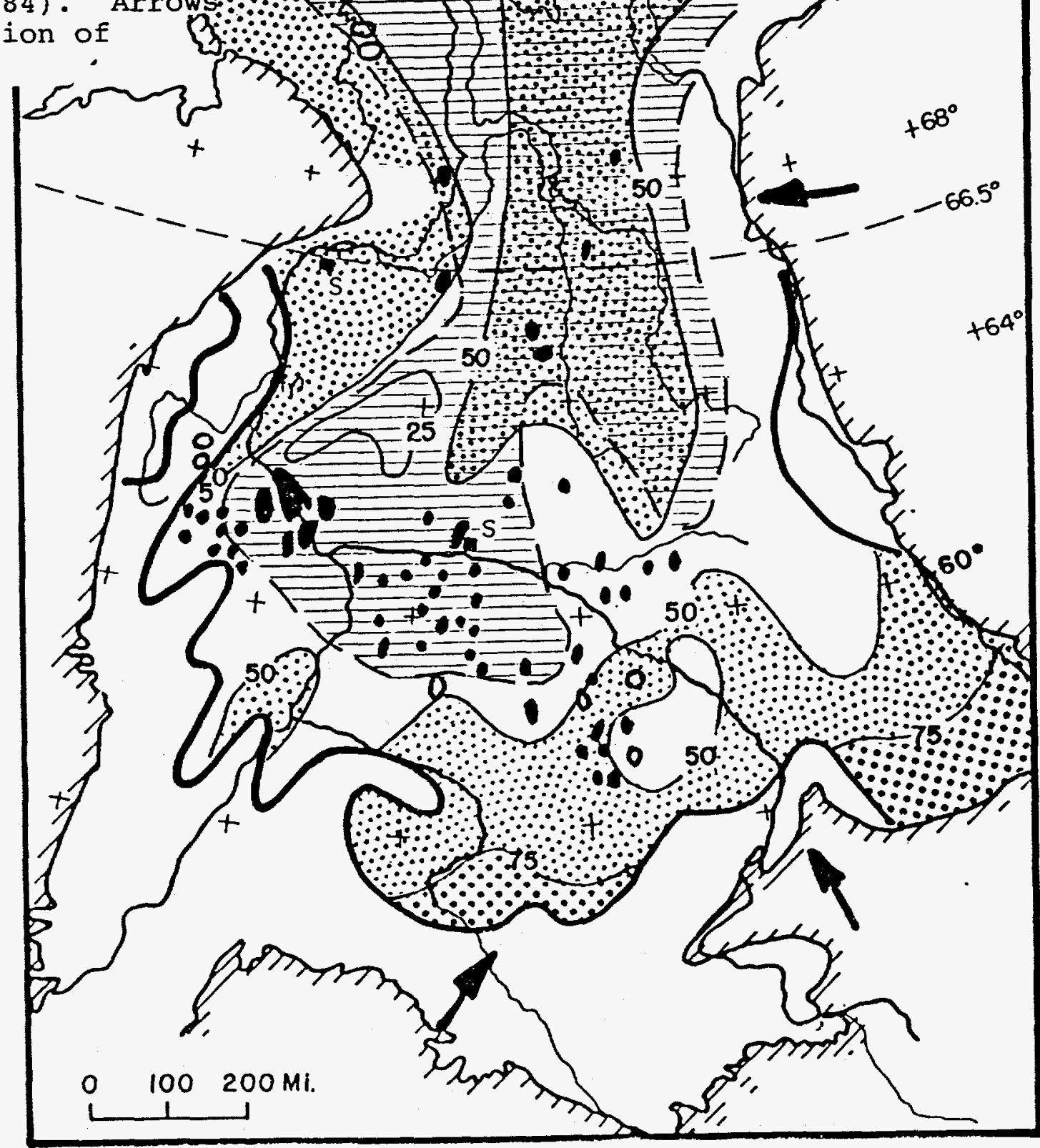

$\Longrightarrow>75 \%$ Sandstone LOWER \& MIDDLE JURASSIC

$>50 \%$ Sandstone

$\Longrightarrow$ Predominantly sapropelic Oil Field-not to scale organic matter

$\bigcirc$ Gas Field - not to scale 
Figure 66. Percent sandstone,

Upper Jurassic rocks, showing areas of predominantly sapropelic organic matter, and general distrioution of oil and gas fields producing from Upper Jurassic reservoirs. Nesterov, 1976). show direction of transport of clastic sediments

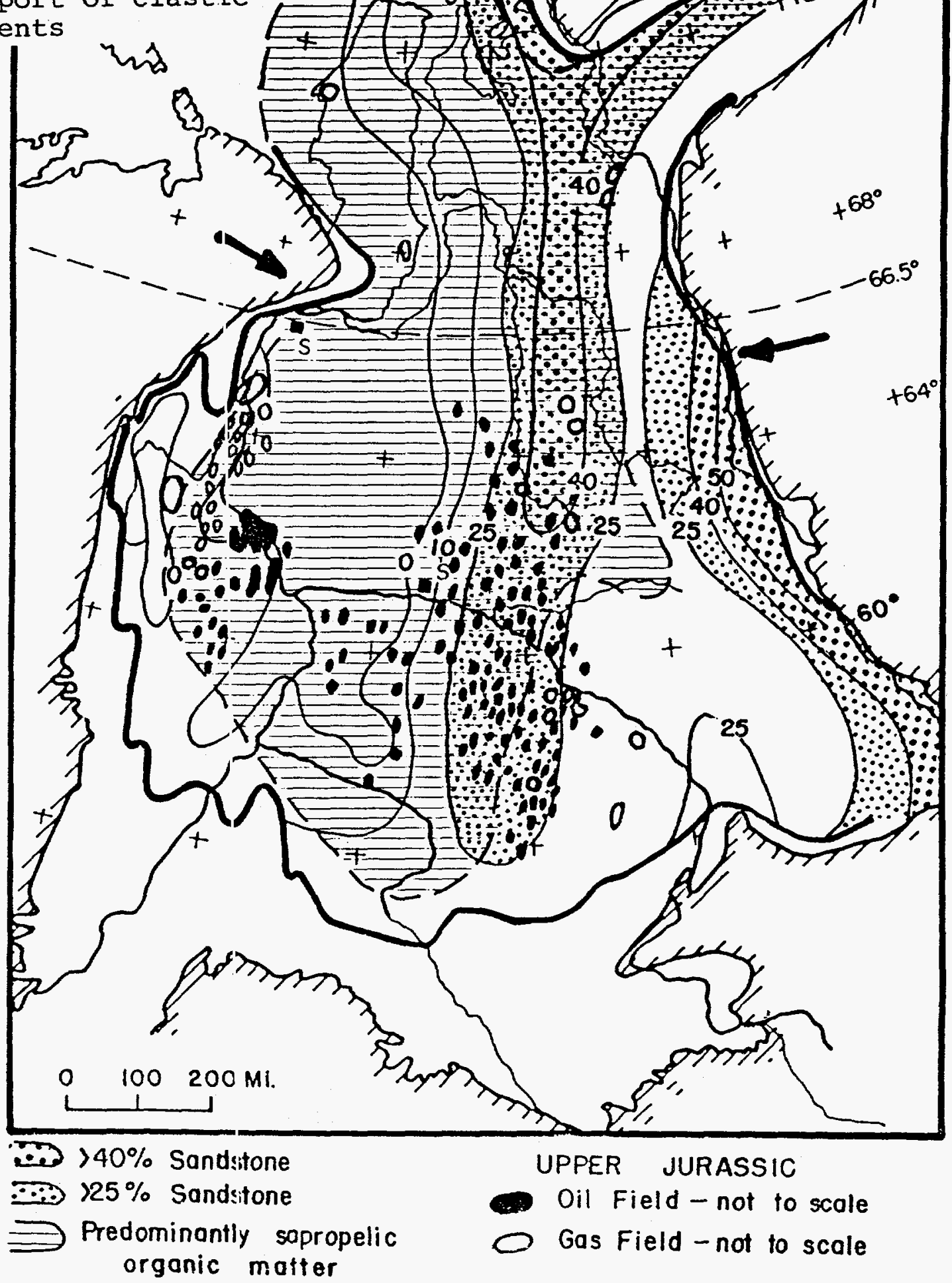




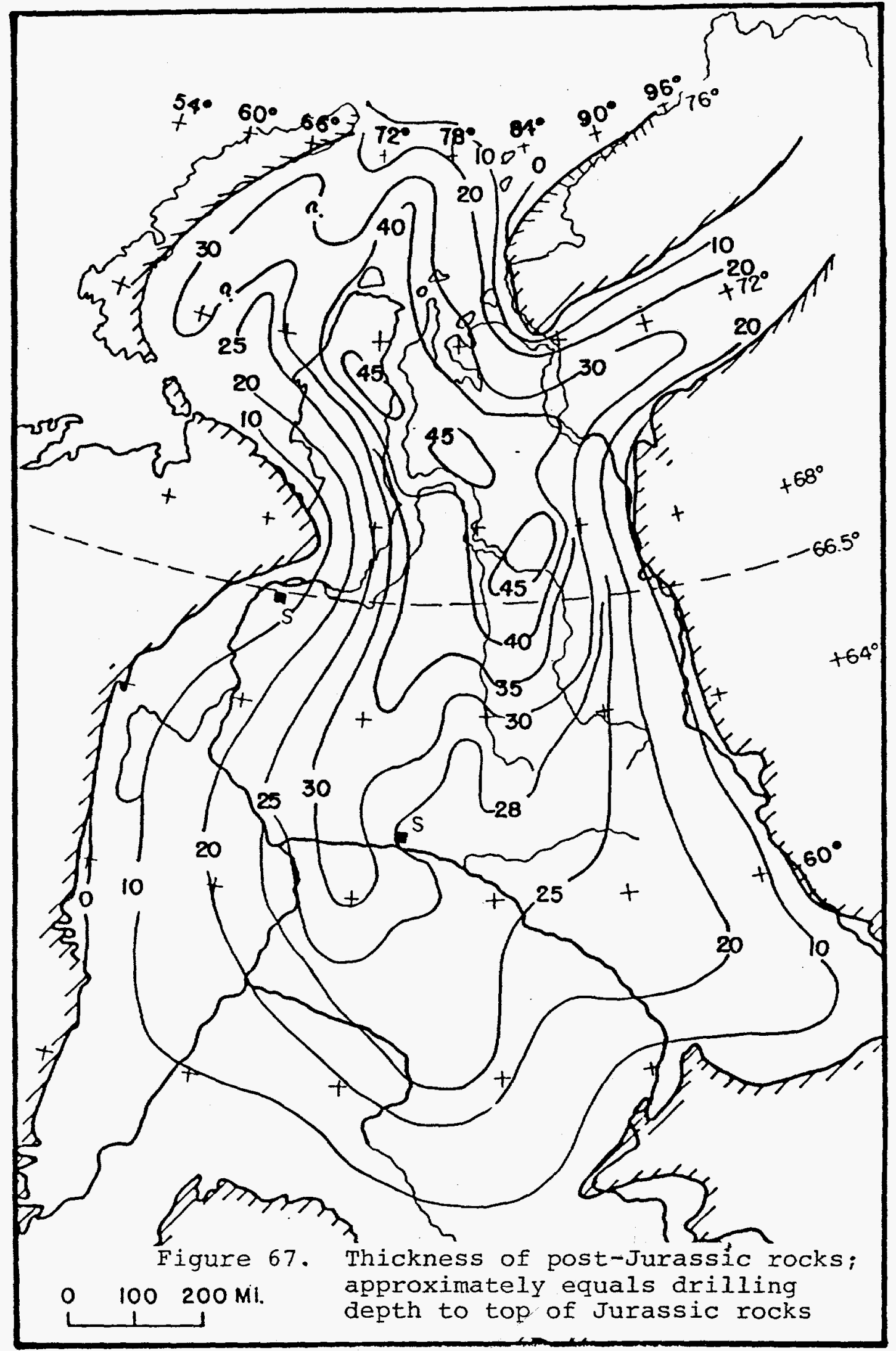

POST-JURASSIC ROCKS

Thickness in hundreds of $\mathrm{m}$. 
foredelta facies extending along the eastern border of the Middle $O b$ region (figs. 25, 66). Within this belt are found the thickest and most porous sandstone reservoirs, many with a north-south channel-sand configuration. The del.taic facies grades westward into organic-rich marine argillaceous becls with a low sand content (Filina, 1974; Ovanesov and others, 1975). A similar deltaic facies is present in the LowerMiddle Jurassic Tyumen Formation, but much of this facies includes lacustrine and swamp deposits, and the sandstones are generally of low permeability and porosity, although some channel sandstones of higher porosity are present. Jurassic rocks, particularly those of the Upper Jurassic, are exceptionally high in organic material, predominantly sapropelic in the basin interior (figs. 21, 25, 28, 64-66). LowerMiddle Jurassic rocks are characterized by mainly humic organic material, with coal beds prominent in the central and southern basin, where lacustrine and swampy beds are common. Marine sapropelic organic matter is particularly abundant in Upper Jurassic rocks over much of the basin, except for the eastern and southern areas, where humic matter and some coals are present (fig. 66). The following table is from Yermakov and Skorobogatov (1984):

Average content o: total organic carbon (percent) in Jurassic of West Siberia:

Clays and argillites

6.858

Volgian

Kimmeridgian

Callovian-Oxfordian

Lower \& Middle Jurassic
2.858

1.768

2.628 Sandstones and siltstones

Average total organic carbon content of Upper Jurassic rocks is also given as follows (Skorobogatov, 1980):

Vasyugan Formation \& equivalents

Georgiyev Formation

Bazhenov Fornation
1.918

2.858

$7.128(10-128$ in the

Mansiysk region; $3.4-5.58$

in the north basin area)

Regional shale seails are present in the upper part of the Upper Jurassic section (Bazhenov and Georgiyev Formations and the upper part of the Tyumen Formation). Seals tend to be discontinuous in the Lower and Middle Jurassic sect:.on, although persistent clay or shale intervals are present in the middle and lower part of the Tyumen Formation. 
3ecause of high quality source rocks, the Jurassic section has a high generating capacity, but because of poorer reservoir development, it contains much fewer large fields than does the Cretaceous section (Yermakov and Skorobogatov, 1984c). Because of better reservoirs and a better overlying seal (Bazhenov Formation and lower Neocomian shale), greater reserves are found in the Upper Jurassic Vasyugan Formation reservoirs and their equivalents than in the Lower and Middle Jurassic Tyumen Formation reservoirs.

Several main areas of Jurassic production or potential production are delineated in the West Siberian basin (Rudkevich and Ozeranskaya, 1983): Kaymysov, Vasyugan, and Paydugin regions - Sixty-five or more oil and oil-gas fields productive from Jurassic reservoirs or from weathered granitic-metamorphic rocks are located in these three regions in the southeastern part of the basin (figs. 55, 56, 64-66). Most of the fields are located on domal or anticlinal structures that reflect basement highs or buried hills beneath the Jurassic unconformity. Production is mainly from sandstone and siltstone reservoirs in the Vasyugan Formation (Upper Jurassic), and in some fields from Middle Jurassic sandstone or siltstone reservoirs of the Tyumen Formation. Reservoirs are present also as updip stratigraphic trap pinchouts on weathered granite hills beneath the unconformity. A few fields, particularly in the Nyurol and southern Vasyugan regions, are also productive from Paleozoic carbonate reservoirs and weathered basement rocks. Some minor production in these regions comes from Neocomian sandstone or siltstone reservoirs.

Middle $O b$ and southern parts of Nadym-Pur and Pur-Taz Regions - A large number of fields produce oil or oil-gas from Jurassic sandstone and siltstone reservoirs in these regions of the central basin area (figs. $17,18,55,56,58,59,65,66)$. The Lower-Middle Jurassic beds are mainly continental in this region (Brushtov and others, 1975; Filina, 1974), and pools are small. The Upper Jurassic beds are mainly marine and littoral-marine deltaic and foredeltaic deposits with relatively persistent sandstones, many with good porosity and permeability, interbedded with shale. Shale content increases rapidly from east to west across the region. The sandy facies is most prevalent on the Nizhnevartov arch and on other structures to the north and south, becoming increasingly discontinuous and more shaly toward the west in the area of the Surgut arch. Most of the oil pools are on the periphery of the Nizhnevartov arch, and traps are mostly stratigraphic-structural. Sandstone reservoirs commonly wedge-out updip on domes or anticlines, and at least half of the traps are classed as stratigraphic (Buurshtk and others, 1975).

Organic-rich marine sapropelic beds are prominent in most of the Jurassic section across the entire Middle Ob area, particularly in the Upper Jurassic, where the Bazhenov Formation makes a regional seal as well as rich source rock for Jurassic oil (figs, 17, 18, 64-66). The 
relatively thick overlying lower Neocomicn shale section also provides an additional regional seal for Jurassic sandstone pools, as well as for fractured shale pools in the Bazhenov.

Near-Ural and Frolov regions - These productive regions occupy the western part of the West Siberian province. In the early 1950's, the first discoveries in this province were made here. The area stands apart geologically from the rest of the province in that the prolific deltaic and other nearshore sandstones of the central and northern regions are not present, having shaled out westward into the Mansiysk depression (figs. 55, 60,65, 66). Parallel with the facies changes, however, is the appearance of a widespread Lower-Middle Jurassic western sandy reservoir facies of the Tyumen Formation that commonly pinches out against erosional residials on the pre-Jurassic surface. These deposits are mainly continental sand-clay coal-bearing rocks derived from ancestral Ural highland; on the west. Toward the east, they grade into coastal plain and marini deposits. Overlying the Tyumen Formation are Upper Jurassic argillacious rocks of the Vasyugan, Georgiyev, and Bazhenov Formations (Dilenshteyn, 1977). These rocks become sandy on the west toward the Ura.. source area. Dark gray, commonly sapropelic, clay or shale formation:; of Neocomian Cretaceous age rest conformably on the Bazhenov Formation in most of the area.

Most oil and gas fields in this area occur in stratigraphic and draped traps over the basement highs. The Berezovo gas area contains 20 or more gas fields. Most reservoirs are basal sandstones of Late Jurassic age, which pinch out against basement highs (Dikenshteyn, 1982; Clarke, 1984). Weathered basement rocks are productive in a few fields. Small gas pools also have been found in sandstone and siltstone reservoirs of late Neocomian age.

The Shaim oil area includes the Shaim arch and a large region of smaller highs to the northwest. Oil pools are in Upper Jurassic basal sandstones, which rest transgressively on and pinchout against buried hills that were islands in the Late Jurassic sea (Ryabukhin, et al, 1969; Clarke, 1984).

In the Frolov oil region, the Krasnoleninsk arch contains several fields, which are depicted as one large field in figure 60 .

Northern area, (Yamal, Gyda, Nadym-Pur, Pur-Taz, Ust'-Yenisey, and Taymyr regions) - As of 1979,50 wells had penetrated to Jurassic rocks in the northern area; only six had reached $4,000 \mathrm{~m}(13,000 \mathrm{ft})$ or deeper.

Jurassic rocks are high in sandstone content across most of the Ust'-Yenisey, Taymyr, and Yamal and Pur-Taz regions (figs. 21, 25, 65, 66). Sapropelic marine shale beds are also widespread, particularly in the central and eastern prarts of the northern area, grading into and 
intertonguing with the adjacent bordering sand facies. For these reasons, significant oil, oil-gas, or gas-condensate accumulations should be present in these rocks. The Jurassic section, however, is buried deeply in much of the northern area and has not been adequately explored (fig. 67). Gas production is reported from Middle and Upper Jurassic sandstone reservoirs in the south part of the Ust'-Yenisey region, and gas has been encountered in at least one field in the Yamal region. Gas-condensate and some oil are found in Jurassic reservoirs in other parts of the north basin. Oil pools are reported in the Vasyugan Formation in the Gubkin, Severo- and Yuzhno-Kharampur, and Verkhnechasel'ka fields and in the Tyumen Formation in the YuzhnoKharampur field (Yermakov and Skorobogatov, 1984). According to these authors, favorable areas for Jurassic exploration are in the Nadym-Pur and Pur-Taz regions, between the Nadym and Taz Rivers, although prospects are likely to yield only small to medium-size gas pools. Lower and Middle Jurassic reservoirs are considered favorable for gascondensate pools, and Upper Jurassic reservoirs for light oil.

According to Yermakov and Skorobogatov (1984), the most probable time of formation of oil and gas pools in the Jurassic rocks of the northern area was in the Neocomian-Albian. Subsequently, the accumulation potential of the Jurassic rocks was decreased considerably due to deterioration of reservoir properties accompanying subsidence and compaction. The possibility for migration of hydrocarbons was reduced sharply. Therefore, the hydrocarbons generated after the Albian were not able to collect in pools but are scattered in a myriad of noncommercial accumulations.

\section{Neocomian}

Reservoirs - Reservoirs of Neocomian age are the main oil producers in the West Siberian basin. Neocomian beds are strongly oil-prone in the central part of the basin (Middle Ob region), where the main oil deposits are located, but are largely gas-prone where productive in the northern area (figs. 55-57, 68-71).

The Neocomian section ranges in thickness from about $800 \mathrm{~m}(2,500$ $\mathrm{ft}$ ) in the south to more than $1,500 \mathrm{~m}$ ( $5,000 \mathrm{ft}$ ) in the north (fig. 29). At least 30 sandstone and siltstone productive horizons separated by clays or shales are present (Yermakov and Skorobogatov, 1984c), including the B1 - B22 horizons of Valanganian-Hauterivian age and the A1 - A12 horizons of upper Hauterivian-Barremian age (Ozeranskaya, 1979). Most of the reservoirs shale out from east to west; the sandstone content of the Neocomian is 608 or more on the east side of the basin, 25-408 in the Middle Ob region, and less than $10 \%$ in the west side of the basin (figs. 30-34, 68-71).

Most reservoirs are nearshore marine deltaic, interdeltaic, or fluvial sandstone bodies derived from source terranes on the southeast 
Figure 68. Percent

sandstone, Lower

Cretāceous, lower

and middle Valanginian

rocks, showing areas

of predominantly

sapropelic organic

matter (from Nesterov,

1976). Arrows show

transport direction

of clastic sediments

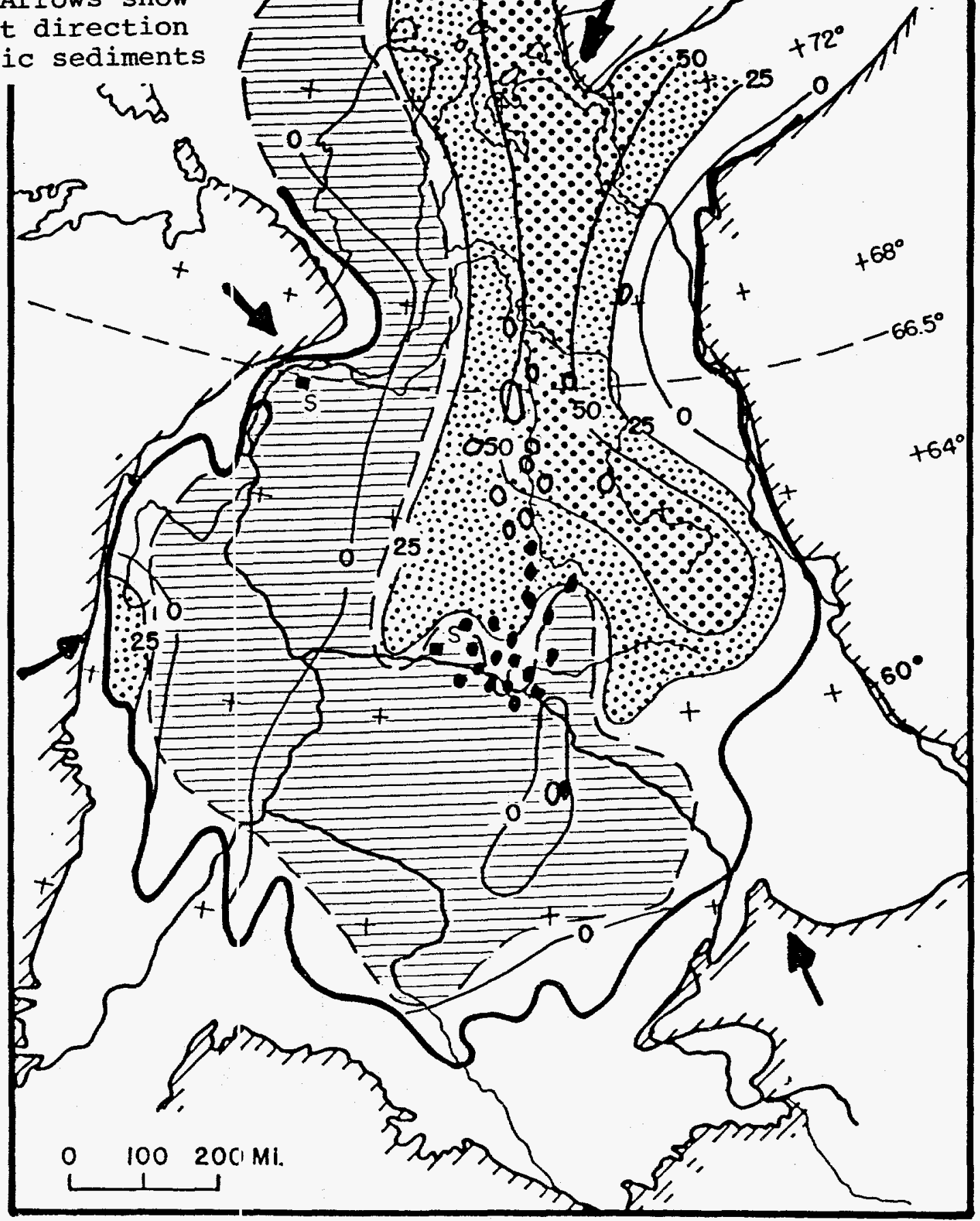

$\because 3>50 \%$ Sandstone

$\because \because 925 \%$ Sandsitone

LOWER \& MIDOLE VALANGANIAN

$\Longrightarrow$ Predominantly sapropelic

O Oil Field (not to scale)

$\checkmark$ Gas Field (not to sca!e) organic matter 
Figure 69. Percent sandstone, Lower Cretaceous, upper Valanginian, showing areas of predominantly sapropelic organic matter, and general distribution of oil and gas fields producing from Valanginian reservoirs (from Nesterov, 1976)

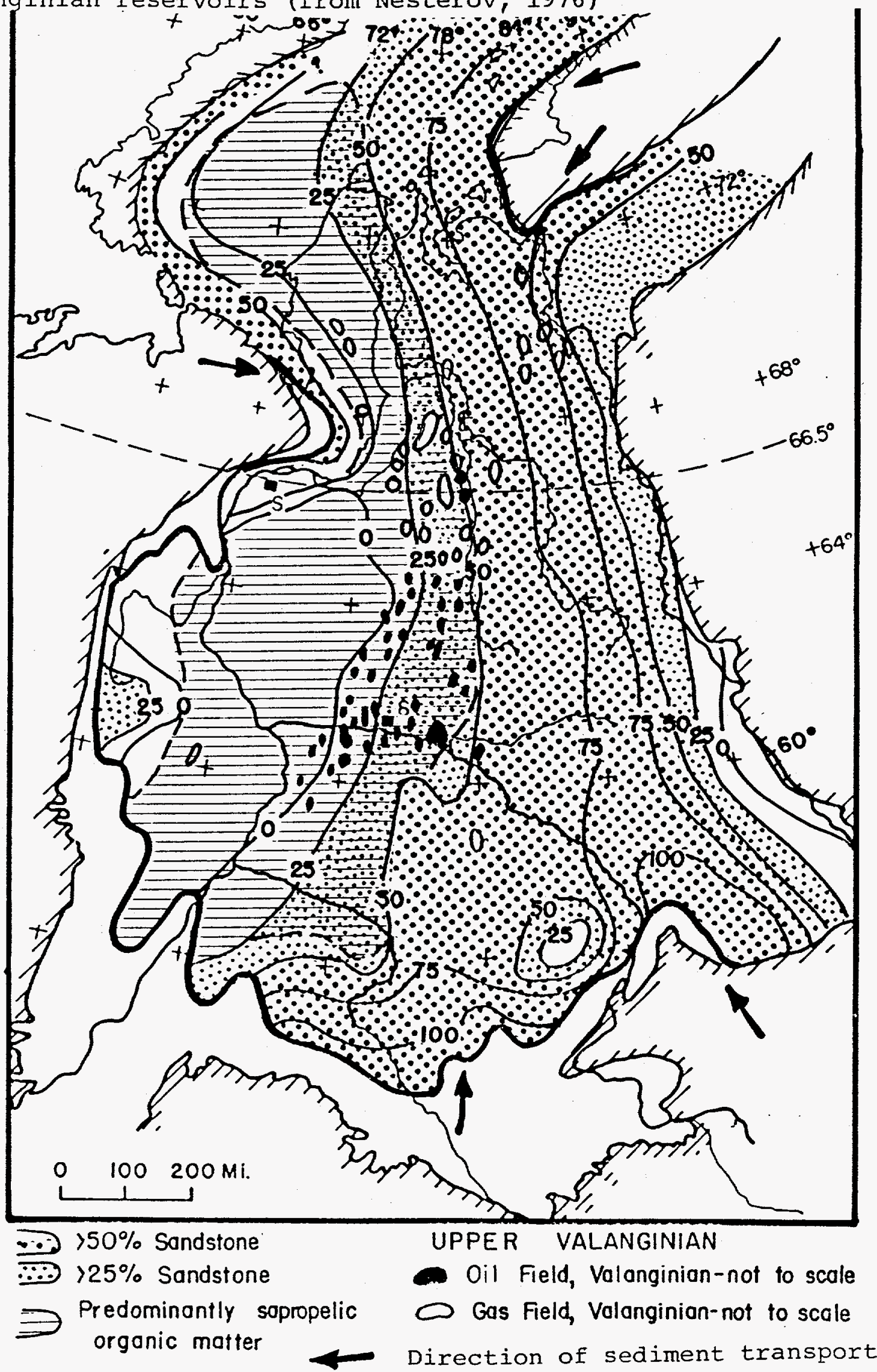




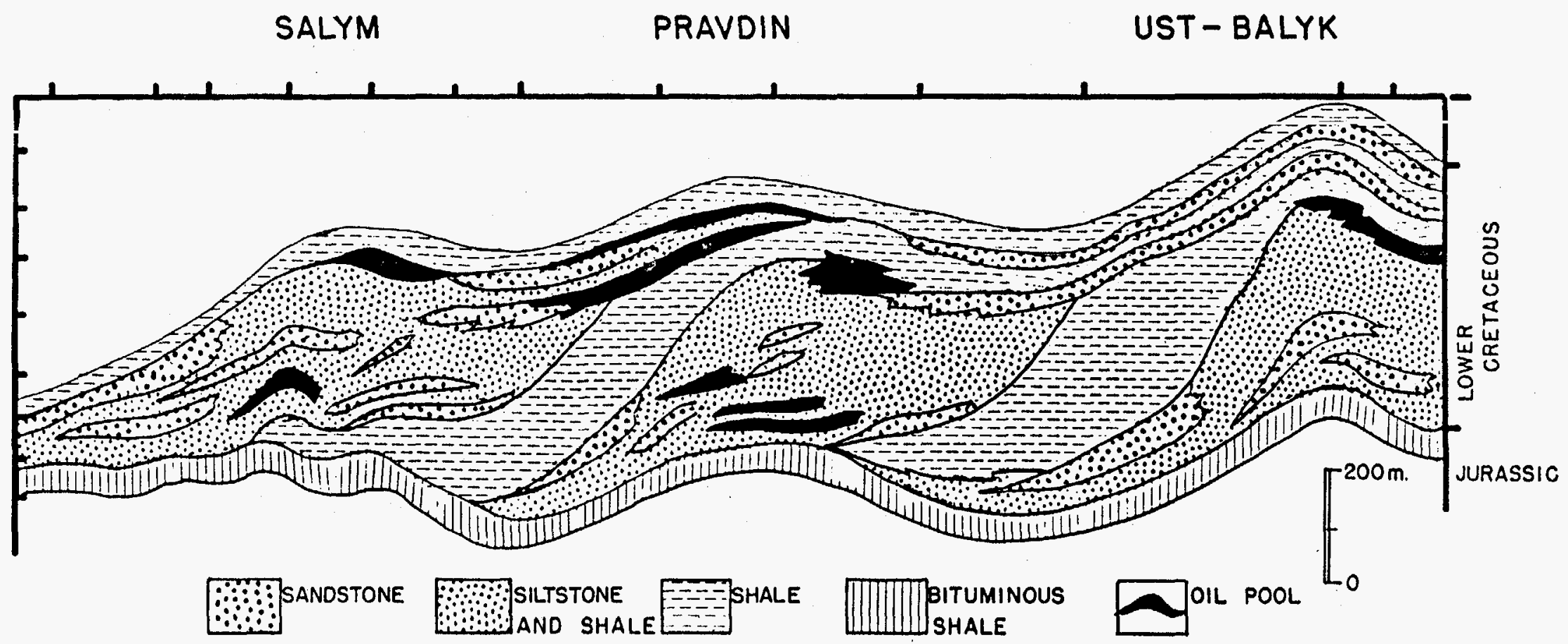

Figure 70. East-west cross section across part of the Middle ob region, showing intertonguing sandstone, siltstone, and shale facies and oil pools (from Rudkevich, 1988) 


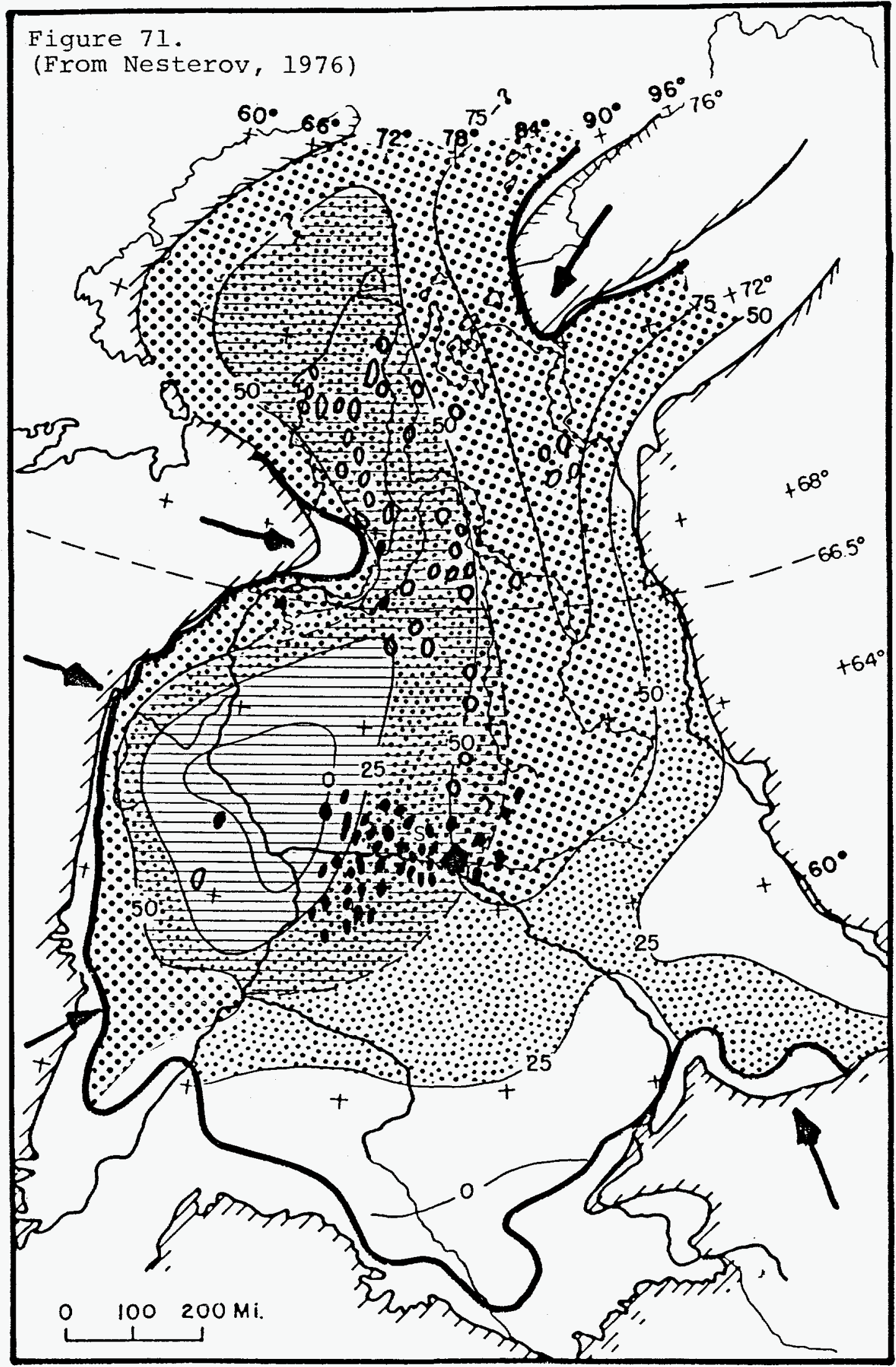

$\because 50 \%$ Sandstone

:P) $25 \%$ Sandstone

HAUTERIVIAN-BARREMIAN-APTIAN

ĐPredominantly sopropelic

$\rightarrow$ Oil Field-not to scale

$\oslash$ Gas Field-not to scale organic matter 
and south. There wasi very little source area on the east because drainage of the Sibelian craton was to the east, leaving very little area between the West: Siberian basin and the Siberian craton immediately on its east for supp].y of detritus westward. Further, the western part of the Siberian cratcin was covered with Triassic basaltic flows, or had sedimentary rocks exposed, and consequently could not have supplied the arkosic sands for the. West Siberian Neocomian deposits. Judging from coarse clastic distribution, another important source area was present in the Taymyr uplift region on the northeast border of the basin (figs. 30-34, 68-71). A less prominent source area that supplied clastic material was the Ural Mountain uplift. The main reservoir facies was deposited near the Neocomian shoreline, which fluctuated east and west across a major northsouth central basin paleo-platform region (Khanty regional high) (Erv'ye, 1974; Yermakov and Skorobogatov, 1984). This paleogeographic pattern resulted in deposition of a thick complex of sandstone and siltstone reservoir beds, separated by transgressive marine shale tongues, many of which are of source rock quality (figs. 30-34, 68-71). These facies changes are well exemplified on the Nizhnevartov and Surgut arches, major segments of the paleo-platform, which contain the bulk of Neocomian oil reserves of the Middle Ob region. Foredelta, shallow bay, and subaerial plain sediments are recognized in the eastern part of the Nizhnevartov arch, grading westward to mainly open marine shaly facies in the western part of the arch. Upward, the section becomes more brackish, lagoonal, and lacustrine, and the maximum sandstone and siltstone content shifts westward, a consequenze of regressive conditions late in the Neocomian. Clay content of individual horizons generally decreases from west to east, while sand sorting and reservoir porosity-permeability increase. Porosity and permeability also increase upward in individual horizons because of lower clay content and better sorting. The distribution of clastic sediments was controlled not only by the shifting fluvialdeltaic and marine enrironments, but also was affected by gentle tectonic movements of the floor of the sedimentary basin. Undoubtedly, superimposed eustatic sea level fluctuations also influenced distribution of the coarser reservoir and associated facies.

Neocomian reserroir sands in the Middle ob region are composed of 25-40\% quartz, 30-55\% feldspar, and 3-6z mica, and are of $0.09-0.18 \mathrm{~mm}$ grain size. To the north (Urengoy and Gubkin fields), these sands are 25-508 quartz, 30-508 feldspar, and 3-108 mica and are of 0.1-0.14 mm grain size (Zaripov and Kulskhnetov, 1974).

Pools in the Micldle ob region are almost all oil or oil-gas. Only in the Cenomanian reservoirs in this area are pure gas pools found (e.g., Samotlor field). Residual oil in these gas pools suggests that the traps were once filled entirely by oil, and that oil was later displaced out of the traps by thermal gas resulting from greater subsidence of the source beds or by gas liberated from solution as a result of Tertiary uplift, erosion, and reduction of formation pressure. 
With depth, there is a general decrease in oil density, tar, asphalt, and sulphur, and an increase in paraffin content (Ozeranskaya, 1979). Most stratigraphic traps are found within the regional pinchout (shaleout) zones of the sandstone horizons. Regionally, the shaleout zones run southwest to northeast across the approximate basin center (figs. 68-71) (Binshtok, 1980).

Stages of oil-gas accumulation in Neocomian reservoirs of the Middle Ob region are analyzed by Ozeranskaya (1979) and Schepetkin (1980) as follows:

First stage - early Turonian time; first phase of oil-gas accumulation in the Middle Ob region.

Second stage - oil filling completed by the end of the Mesozoic.

Third stage - Migration of gas-condensate and gas from depressions to the north of the Middle $\mathrm{Ob}$ region, related to neotectonic uplift and separation of gas from solution in formation waters. This process resulted in formation of the gas caps.

Source Rocks - Neocomian rocks, mainly clays or shales, are dark colored and bituminous, particularly in the lower part, in much of the western and central basin areas. Humic organic material is present in variable amounts in the eastern and southern parts of the basin and in parts of the Near-Ural western fringe of the basin (figs. 30-34, 64, 68, 69, 71). Higher values generally are found in the Berriasian and Valanganian section, but values as high as 18 or more also are present in the Hauterivian-Barremian section. In general, reported values are higher in the north basin. Calculations on type and distribution of organic matter in the basin are given by Yermakov and Skorobogatov, (1984d): 
Berriasian-Valanginian

West and central regions of platform (predominantly sapropelic and humicsapropelic disseminated organic matter)

\section{Northern region}

(humic components are greater and coal beds are prisent)

\section{Hauterivian-Barr mian}

\section{Middle $O b$ and Mallsiysk region}

(sapropelic-humic disseminated organic matter, grading io sapropelic)

Northern region

Aptian-Cenomanian!

(mostly humic disiseminated organic matter)
$0.5-2.08$ (av. 0.668) in clays;

$0.3-0.68$ (av. 0.58) in sandstones and siltstones
$1.058 \mathrm{av}$. in clays; $0.658 \mathrm{av}$. in sandstones and siltstones
0.38 in east to 1.08 in west (av. 0.498 ) in clays;
$0.2-0.68$ (av. 0.358 ) in sandstones and siltstones

0.898 av. in clays; 0.708 av. in sandstones and siltstones

\footnotetext{
1.118 av. in clays; 1.028 av. in sandstones and siltstones Concentrated organic matter (coal beds) comprises $3-5 \%$ of total organic matter in AptianCenomanian.
}

Thickness of beds of concentrated organic matter (coal) in the Neocomian-Cenomanian sediments of the north of West Siberian basin ranges from 10 to $15 \mathrm{~m}$ ( 33 to $50 \mathrm{ft}$ ) along the margins of the basin to $30 \mathrm{~m}$ (100 ft) in the central parts. The total mass of organic, matter in West Siberia is as follows:

Berriasian-Valanginian, $6.7 \times 10^{12}$ tons; Hauterivian-Barremian, $10.0 \mathrm{x}$ $10^{12}$ tons; and Aptian-Cenomanian, $48.4 \times 10^{12}$ tons. 
Yermakov and Skorobogatov (1984) give the following calculations:

\begin{tabular}{|c|c|c|c|c|c|}
\hline \multirow{2}{*}{$\begin{array}{l}\text { Oil-gas } \\
\text { complex }\end{array}$} & \multirow{2}{*}{$\begin{array}{l}\text { Disseminated } \\
\text { organic } \\
\text { matter }\end{array}$} & \multirow{2}{*}{$\begin{array}{l}\text { Total content of } \\
\text { organic matter } \\
(10 \stackrel{12}{\text { tons })}\end{array}$} & \multicolumn{3}{|c|}{ Hydrocarbons generated 1012} \\
\hline & & & Methane & Bituminoids & Total \\
\hline Aptian- & Humic & 17.10 & 0.230 & 0.049 & 0.279 \\
\hline Cenomanian & Sapropelic & 4.27 & 0.097 & 0.307 & 0.404 \\
\hline \multirow[t]{2}{*}{ Neocomian } & Humic & 11.22 & 0.273 & 0.063 & 0.336 \\
\hline & Sapropelic & 11.22 & 0.385 & 1.406 & 1.791 \\
\hline
\end{tabular}

According to Yermakov and Skorobogatov (1984), maximum temperature achieved in the Neocomian beds was $90-140^{\circ} \mathrm{C}$, and the type of hydrocarbon was controlled largely by the type of organic matter. From south to north in the central basin area, the composition of disseminated organic matter changes from 60-908 sapropelic and humic-sapropelic in the Middle Ob area to 30-40z in the Nadym-Pur and Pur-Taz regions, to 20-30z on the Yamal and Gyda Peninsulas, accompanied by a northward change to less marine material. In the same direction, a shift occurs from predominantly oil in the Middle Ob region to gas-condensate-oil immediately north of the Middle Ob area, then to gas- condensate farther north. Small oil rings are present in the Urengoy, Taz, and Yamburg areas. 
Seals - Shale (clay) units of both marine and nonmarine origin and of both regional and local extent are common within and overlying the Neocomian section. Most widespread are the marine shale units deposited during major transgressions following deposition of deltaic, interdeltaic, and alluvial plain regressive facies, which contain the main reservoir sandstone and siltstone units. Within the Neocomianbasal Aptian sandstone complex, individual sandstone reservoirs were locally sealed contemporaneously by interbedded clay units deposited during brief minor transgressive stages following coarser clastic deposition. Regional sealing of the Neocomian sandstone complex was completed by deposition of the thick transgressive marine shale of the Alym Formation. No evaporite seals are known in the West Siberian basin.

Traps - Almost all petroleum accumulations in Neocomian rocks thus far have been found on anticlines or arches, many of them inherited from older basement uplifts. However, few of the reservoir bodies are continuous over long distances but rather tend to be highly irregular in thickness, extent, grain size, and clay content within a given horizon. Thus a strong stratigraphic trapping aspect is present in most fields, and many pool traps are located on the flanks of structures as well as on the crest. In the Surgut arch region, Mamleyev (1976) recognized 19 stratigraphic pools cortaining three giant, two large, and one mediumsized accumulations. Iwenty-three percent of the reserves on this arch are estimated to be from such stratigraphic traps. Most structural traps occur in the regional northwesterly and westerly pinch-out zones of the reservoirs and complexes. Pinchouts (or shaleouts) of the sands are currently being mafped by common depth point seismic surveys (Binsktok, 1980).

In horizon BV-10 on the Nizhnevartov arch, at least 20 productive sands are present, most: of which shale out in short distances (Lysyanskiy, 1981). Trickness of individual sands is highly variable, and clay sections occur between sands. In one single interval (Horizon BS-10) of the Surgut arch region, a large area of potential stratigraphic trap accumulations is being outlined in a north-northeast belt 30 to $80 \mathrm{~km}$ ( $20 \mathrm{tc} 50 \mathrm{mi})$ wide and $300 \mathrm{~km}(200 \mathrm{mi})$ long between the Mamontovo field on the south and the Muravlenko field on the north (Nesterov and others, 1.985). Within this belt, there are 16 pay zones in the lower Cretaceous, as well as additional pays in the Jurassic. The combination of continuous paleotectonic growth and shifting depositional environments characteristic of the West Siberian basin combine to make the prospects for finding significant stratigraphic trap pools of major importance for future exploration.

Middle Ob Region - The Middle Ob is the most important oilproducing region of the West Siberian province. Approximately 94 oil and oil-gas fields are present in this region, most of them productive 
from one or more of approximately 30 or more reservoir horizons in the Lower Cretaceous, primarily Neocomian sandstone and siltstone sections. Two large regional uplifts, the Nizhnevartov and Surgut arches, contain the major oil reserves of the province. Exploration began in the Nizhnevartov arch area in 1957. The first field, Megion, was found in 1961 , and the supergiant Samotlor field in 1965. On the Surgut arch, there are 71 structural closures on the top of the Jurassic, 53 on the base of the Aptian, and 38 on the top of the Cenomanian. The pattern is very similar for the Nizhnevartov arch. Most pools are on anticlinal or domal structures, although a strong stratigraphic aspect is associated with most fields. Sandstone horizons are interbedded with shales in the Middle Ob region, and many traps formed penecontemporaneous with deposition as a result of sandstone lensing, pinchouts, shaleouts (facies changes), and differential compaction. As of December, 1984, the Samotlor field, largest in the Soviet Union, had produced $14.7 \mathrm{BB}$ oil. The field peaked in 1980 at $3.0 \mathrm{MMB} / \mathrm{D}$ and for 1985 was at 2.8 MMB/D. Cumulative production by January, 1986 was 12,825 MMB (International Petroleum Encyclopedia, 1987). According to the $0 i 1$ and Gas Journal $(8 / 12 / 85)$, the field has been vastly overdeveloped and damaged in attempts to maintain planned growth of Soviet oil production. A detailed analysis of the Samotlor field is found in Nesterov and others, 1971; Clarke and others, 1977.

Northern area - The Neocomian beds are largely gas prone in the north basin area, related to the increase in humic organic material north of the Middle Ob region. North of the Middle Ob region, Neocomian sandstone and siltstone reservoirs of horizons $\mathrm{BU}_{8-12}$ of the Megion Formation (Upper Valanginian-lower Hauterivian) are productive of gas and condensate in several fields, all of which also contain gas accumulations in Aptian-Cenomanian reservoirs. Horizon $\mathrm{TP}_{1-6}$ of the Tanopchin Formation (Aptian) also contains gas accumulations on the Yamal and Gyda Peninsulas. Fields in the northern area are all on anticlines or arches, some of large areal extent.

Neocomian reservoirs are productive of gas-condensate and some oil in several fields in the Nadym Pur and Pur-Taz regions, including the supergiant Urengoy field, which now has oil production probably from Valanginian sands. $0 i l$ as well as gas-condensate pools also are present in the Novoport field in the southeastern Yamal Peninsula area. Farther northwest on the Yamal Peninsula, numerous gas-condensate pools and several oil pools in Valanginian, Hauterivian, and Berriasian sands are present in several fields, which also are gas-productive from Cenomanian sands (figs. 17, 31-34, 73).

In the Ust' - Yenisey region of the northeastern basin, several gas fields are present, some of which contain gas-condensate pools in Valanginian and Hauterivian reservoirs as well as Cenomanian reservoirs. All of these fields are on anticlinal or domal structures in a region of 


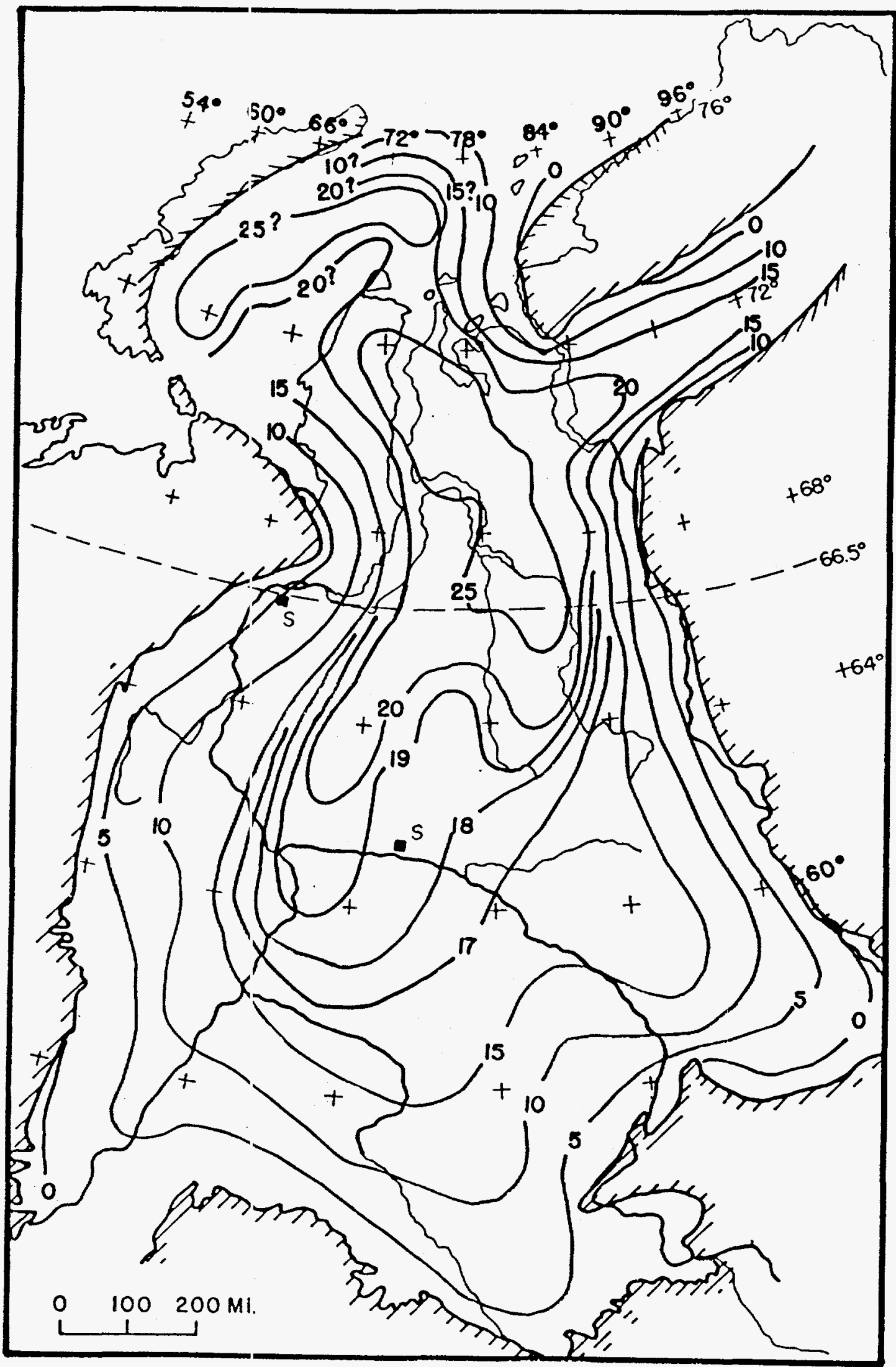

Figure 72. POST-NEOCOMIAN ROCKS
Thickness, hundreds of $\mathrm{m}$.

The thickness approximately equals depth to top of Neocomian rocks. 


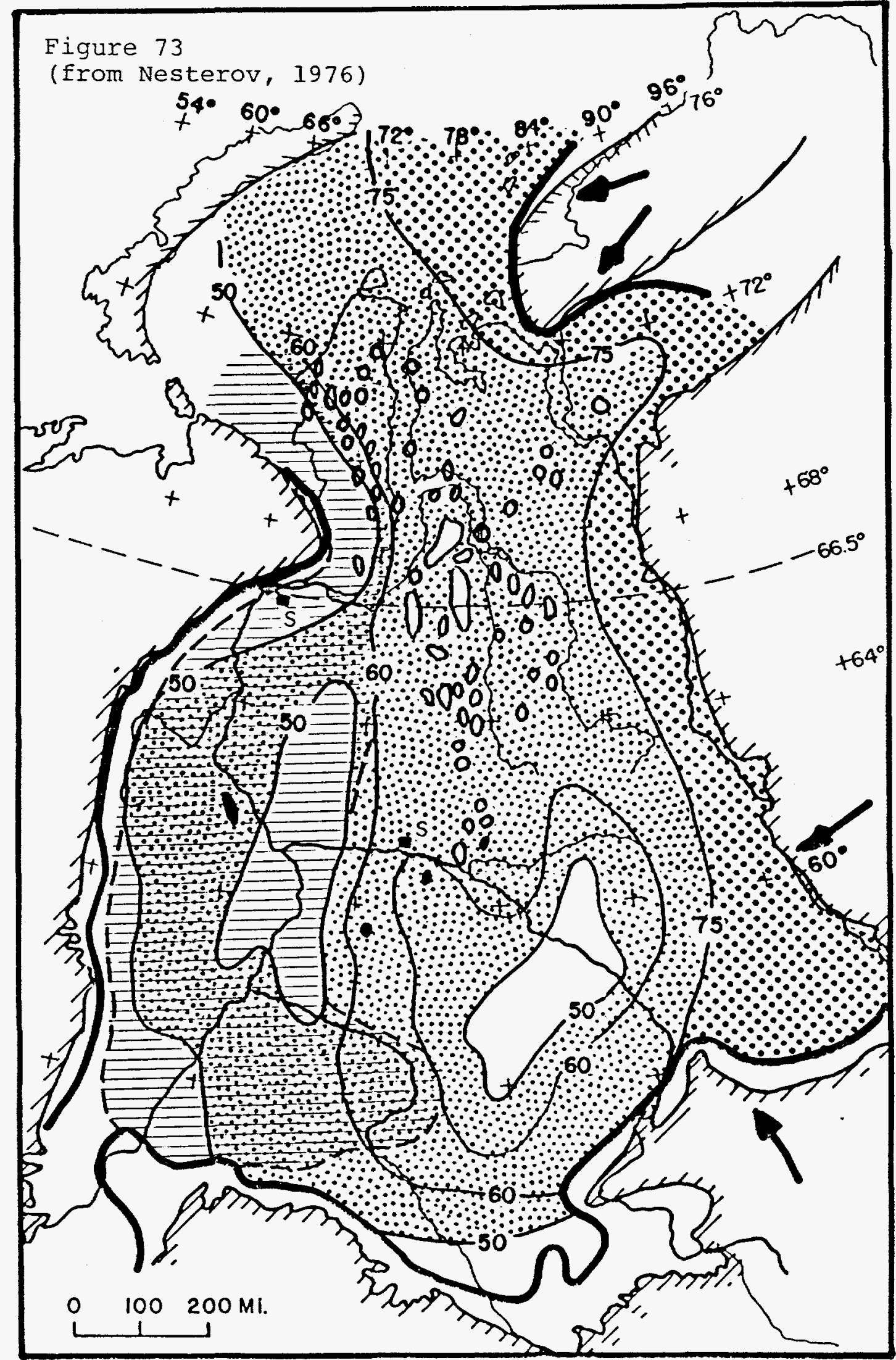

. $75 \%$ Sandstone

:50\% Sandstone

APTIAN-ALBIAN-CENOMANIAN

$\Longrightarrow$ Predominantly sapropelic

$\rightarrow$ Oil Field-not to scale organic matter

$\circlearrowright$ Gas Field-not to scale

Direction of sediment tramsport 
the province where Neocomian rocks are high in sandstone content and contain primarily humic-type organic material (figs. 29-34, 68, 69, 71).

Many of the sandstone-siltstone reservoirs in all these fields are dis-continuous in nature and are interbedded with clay or shale beds, which provide local seals. The thick Aptian-Albian shale section provides an effective regional seal for pools in all of the northern area (figs. 17, 18). In most of the northern area, Neocomian reservoirs are buried to depths of 1,500 to $3,000 \mathrm{~m}(5,000$ to $10,000 \mathrm{ft})$ or greater (fig. 72).

\section{Aptian - Albian - Cenomanian}

Hydrocarbon production from post-Neocomian, primarily Cenomanian, reservoirs is almost entirely gas or gas-condensate in fields north of the Middle ob region (figs. 37, 39, 56, 73). Approximately 60 gas and gas-condensate fields have been found, many of them of giant or supergiant size. Approximate size of the largest are: Urengoy, 200 by $20-30 \mathrm{~km}$; Medvezh'ye, 12J by $25 \mathrm{~km}$; Yamburg, 170 by $45 \mathrm{~km}$; Zapolyar, 50 by $30 \mathrm{~km}$; and Taz, 26 by $15 \mathrm{~km}$. Production is from thick, looselycompacted, friable sandstone and siltstone reservoirs interbedded with silty clays containing terrestrial plant remains and coal beds. Total thickness of permeable beds is as much as 500-800 m (1,600-2,500 ft). Sandstone content increases from west to east, reaching $60 \%$ or more to as much as $80 \%$ over a brisad area of the eastern basin (fig. 42). Eighteen main pays are pcesent $\left(\mathrm{PK}_{1}-\mathrm{PK}_{18}\right)$ at $500-1,800 \mathrm{~m}(1,600-$ $6,000 \mathrm{ft}$ ) depths (figs. 74, 75). Most deposits are in the massive pools of the $\mathrm{PK}_{1}-\mathrm{PK}_{6}$ reservoir units in the upper part of the Pokur Formation (Yermakov and ikorobogatov, 1984).

The largest is the pool in $\mathrm{PK}_{1}$, where the gas column is $213 \mathrm{~m}$ (700 ft) high. The Cenomanian pools are massive blanket sandstone deposits laid down during the major Albian-Cenomanian regressive stage of basin evolution, occuring just below the thick Turonian. Sixty-two percent of the proven reserves of non-associated gas in the West Siberian basin are in these reservoirs. These gases differ greatly from those of the Lower Cretaceous and Jurassic, which contain a wide range of heavier hydrocarbons, reaching a maximum of 308 or more $\mathrm{C}_{2} \mathrm{H}_{6}$ in the Middle $\mathrm{Ob}$ region. Gases in the post-Neocomian are mainly dry methane with only a small percentage of higher gases, mainly ethane and almost no $\mathrm{N}, \mathrm{CO}_{2}$, or $\mathrm{H}_{2} \mathrm{~S}$, a composition related to generation from humic organic matter at the $\mathrm{B}_{2}-\mathrm{B}_{3}$ stage or coalilication or to bacterial destruction of all gases heavier than methane. The gases are low in condensate, e.g. at Urengoy, $0.20 \mathrm{~g} / \mathrm{cm}^{3}$ gas and Medvezh'ye, $0.25 \mathrm{~g} / \mathrm{m}^{3}$ gas. The gases in the Lower Cretaceous, howeves, are very high in condensate, values ranging from 56 to $610 \mathrm{~g} / \mathrm{m}^{3}$. Ve1:y high reserves of condensate are found in some fields. 


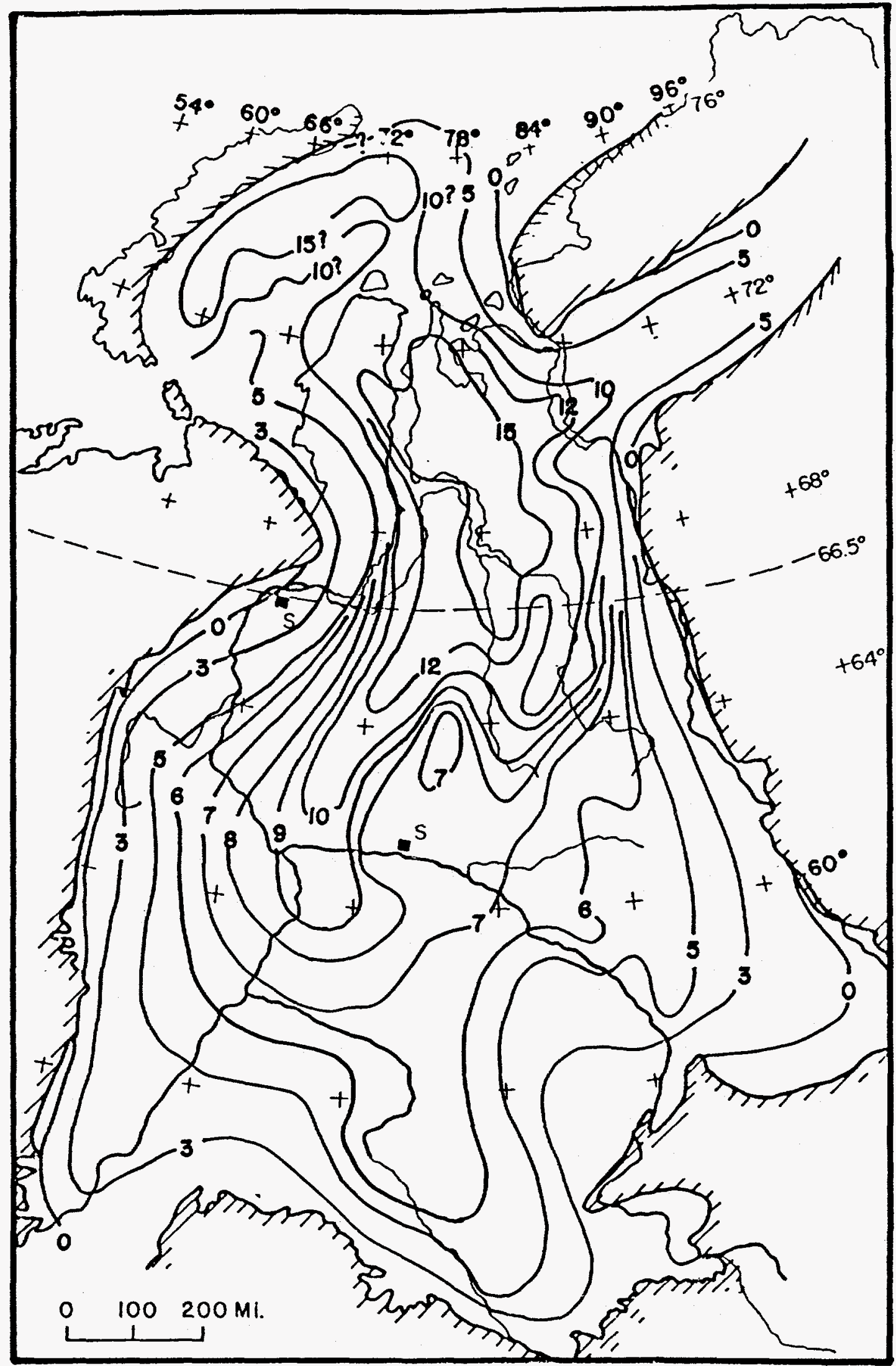

Figure 74.

POST-CENOMANIAN ROGKS Thickness, hundreds of $\mathrm{m}$.

Thickness equals approximate drilling depth to top of Cenomanian 


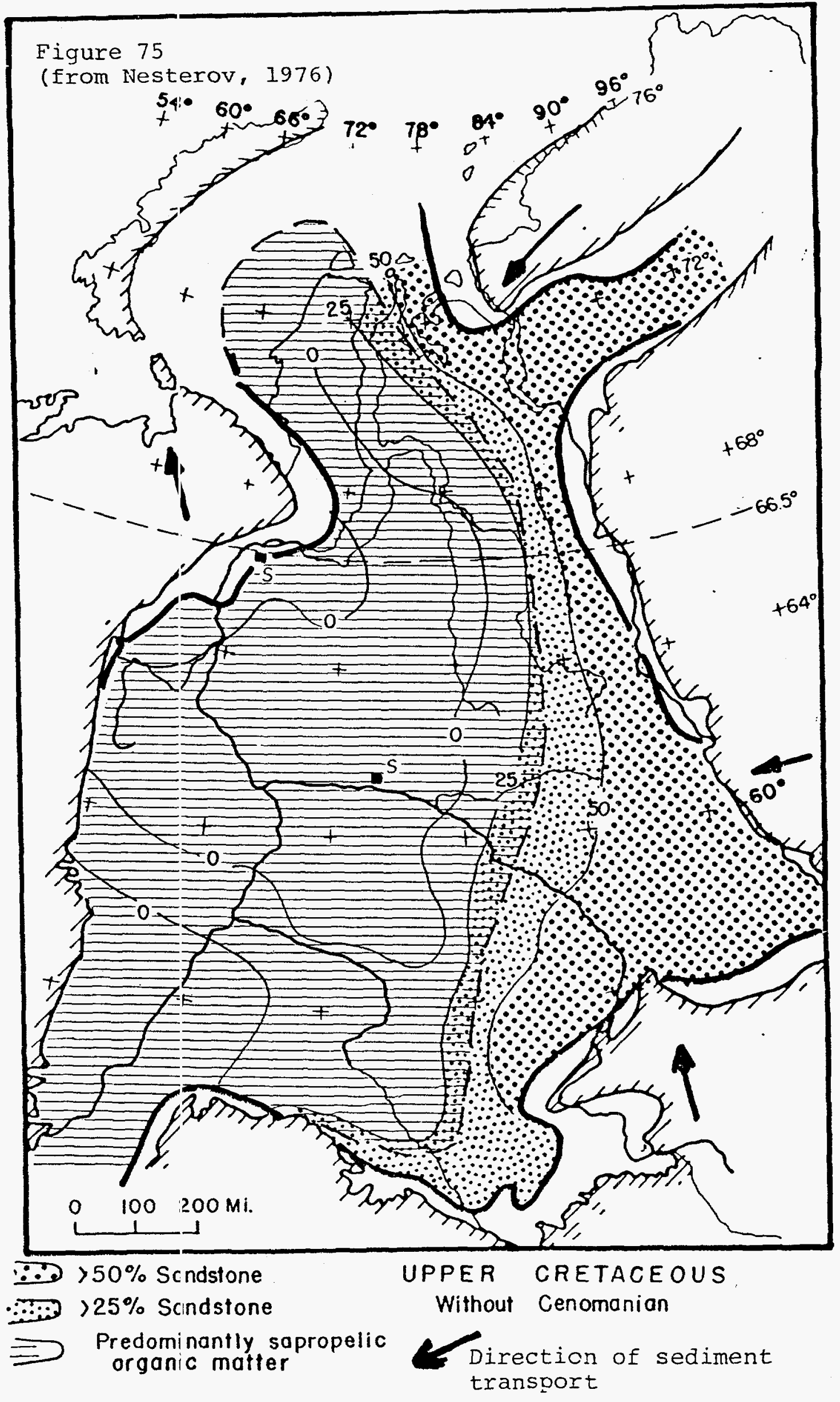


Acsording to Yermakov and Skorobogatov (1984), the main factors accounting for the huge reserves of gas in the north basin are:

1. High contents of disseminated and concentrated (coal) organic matter of humic composition matured at subbituminous stage of catagenesis to form large quantities of gas.

2. Large volumes of source and reservoir rocks in which migration capacity was high.

3. Large structures with great closure far from the borders of the basin.

4. The presence of thick seals.

5. Relatively "young" age of formation of the gas accumulations.

These genetic conditions are best for the Hauterivian-Cenomanian sediments of the central part of the northern region (Urengoy, Yamburg, $\mathrm{Taz}$, and Nadym) and to a lesser degree for the Valanginian sediments of the Nadym-Taz interfluve and also the Neocomian-Aptian and AlbianCenomanian sediments of the Yamal and Gyda oil-gas regions. The differences in vertical distribution are governed by the presence of seals in the section (Yermakov and Skorobogatov, 1984).

Calculations show that at the end of the Cenomanian the organic matter of the Hauterivian-Cenomanian sediments reached the middle brown coal stage. High concentrations of coaly material led to generation of large amounts of methane. Most of this gas was lost, because no seal was yet in place. A second stage of generation began in the Turonian after the Cenomanian and older reservoirs were well sealed by the overlying regional Turonian clays. Gas did not migrate from deeper horizons at this time because it was sealed by Aptian-Albian and Neocomian clays. Between Turonian and middle Oligocene time, gas generation continued as organic matter reached the early long flame coal stage. This gas was trapped in Cenomanian and older reservoir sands. The lower part of the thick Turonian clays may have generated substantial amounts of biogenic gas which, unable to escape upward, migrated downward to contribute to the almost pure methane in the Cenomanian reservoirs. In the middle oligocene and Neogene, gas generation essentially ceased because of regional uplift, but redistribution of the earlier trapped gas accumulations occurred. The decrease in pressure accompanying the late Tertiary uplift and erosion certainly led to release of gas from solution in the formation waters of the Mesozoic sediments, thereby adding yet more gas to that already present in the reservoirs. Still other quantities of gas may have been supplied from the formation waters as a result of freezing to great depth during glacial times. As the rock became frozen, the gas in water solution would have gone into the gas hydrate stage. On subsequent 
thawing during interglacial time, part of the gas released by melting of the hydrates would remein as free gas to collect in the reservoirs.

\section{CONCLUSION}

Among the world's petroleum provinces, the West Siberian basin is geologically distinctive in several aspects. The factors of basin size, paleostructural history, continental-marine facies interchange and cyclic depositional history, abundant source rock and reservoir facies, and efficient petroleur. generation and preservation conditions combine to make it one of the world's foremost petroleum provinces. This enormous basin, the world's largest intracratonic basin, underwent a remarkably stable, but paleostructurally mildly-active, Mesozoic depositional history of slow subsidence and basin filling, all of which combined to provide optimum environmental conditions for petroleum accumulation and preservation. Terrigenous sediment influx, mainly from the southeast, was sufficiently great for coarse clastic materials to spread widely across the eastern half of the basin and intertongue with marine sapropelic facies of the open basin to the west. At the same time, the basin was sufficiently large and subsidence rates were great enough that terrigenous sediment influx did not fill it entirely. This imbalance allowed the development of partially starved-basin conditions in much of the west half of the basin, where as much as 2,500-3,000 m $(8,000-10,000 \mathrm{ft})$ of dark marine shale, much of it rich in organic matter, was deposited between Middle Jurassic and early Tertiary time. During most of Early Cretaceous time, the site of the deltaic-open basin transition was across the central basin area, the Khanty regional high, a regional paleostructural feature of the basin apparently inherited from late Paleozoic Hercynian tectonic activity. Continuous but mild paleostructural growth of the Khanty regional high and associated smaller structural elements provided a broad shallow-water intrabasin platform where the immense deltaic and continental eastern facies spread out along the fluctuating Lower Cretaceous shoreline belt. Minor transgressive-regressive cycles of sea level change and paleostructural growth in this environmental setting provided optimum conditions for reworking and winnowing the feldspathic deltaic and interdeltaic sands, with consequent improvenent of reservoir characteristics. During transgressive phases of the minor cycles, the outer deltaic belt shifted eastward, and marine sapropelic muds were deposited over and intertongued with deltaic fringe, longshore, and channel sand bodies to provide a remarkably efficient source rock-reservoir-seal interrelationship.

Continuous mild structural growth of the central basin was a major factor in allowing this combination of circumstances to exist for sufficient length of tine to construct such a regionally extensive reservoir-source rock complex as exists in the Nizhnevartov, Surgut, Urengoy, Yamburg, and other areas of the central basin. The extensive data on source rock parameters published by Soviet geologists show that 
the source rock quality of the basin is unusually high. This aspect appears to be related in part to the regional paleostructure of the basin, with relatively rapid subsidence of the western basin trough providing a semi-starved restricted circulation depression where accumulation of marine plankton under anoxic deeper-water bottom conditions allowed the preservation of unusually large amounts of marine organic material for ultimate oil generation. The high organic content of the basin may have been partly related to the paleogeographic setting of the basin with respect to the broad, silled connection with the openocean Arctic basin on the north. Southward circulation of cooler nutrient-rich marine waters across the North Siberian sill into the warmer-water epicontinental basin would have stimulated the production and accumulation of plankton-derived organic matter to an unusually high degree, particularly during regressive stages of lower sea level.

Aside from these sedimentary and paleostructural factors, a most important aspect of the West Siberian basin is the fact that the entire basin remains essentially intact today. Post-depositional tectonic activity has been only mildly epeirogenic, compared with many other sedimentary basins of the world, so that the early accumulations of petroleum in stratigraphic and structural traps remain relatively undisturbed and therefore preserved.

Over the past 20 years, the West Siberian basin, particularly the central part, has undergone relatively intensive exploration. However, large segments of the basin region are relatively unexplored, particularly the South Kara Sea basin and the Yenisey-Khatanga trough. Both these areas are promising, especially for natural gas and probably oil. Burial depths for Jurassic rocks are greater than 4 to $5 \mathrm{~km}$ in the deeper parts but are probably less than $3 \mathrm{~km}$ in much of these areas (fig. 67). The major Jurassic and Cretaceous source rock facies should extend northward into both these regions (figs. 17, 25-42). The Taymyr uplift and probably Novaya Zemlya were clastic source areas during most of Mesozoic time. Reservoir sands sourced from these uplifts should be present in stratigraphic relationship with source rock facies and seals, not unlike that of the productive areas to the south.

Most of the basin reserves of both oil and gas have been found in local structures on regional highs, but many of the pools are stratigraphic (1ithologic of Soviet authors) or combination structuralstratigraphic. The intertonguing cyclic sequence of deltaic and nearshore marine sandstone, siltstone, and bituminous shale facies characteristic of much of the basin deposition should provide excellent prospects for stratigraphic trap accumulations. Important resources of undiscovered oil and gas will undoubtedly be found in such traṕs, similar to many of those already found in the Middle Ob area (figs. 17 , $18,70)$. 
U.S. Geologiral Survey modal estimates of undiscovered conventionally recoveralsle petroleum resources for the West Siberian basin (1987) are 30 BBO (billion barrels oil) and 350 TCF (trillion cubic feet) gas. 
Abdullin, R.A., 1980, Nature of filtration properties of rocks of the Bazhenov Formation of Salym Field of West Siberia [in Russian]: Geol. Nefti. i gaza, no. 11, p. 19-25 (English summary in Petroleum Geology, v. 18, no. 11,1982 , p. 512-515).

Academy of Sciences, USSR, 1968, Moscow

Akramkhodzhayev, A.M. and Kirshin, A.V., 1981, Development of theoretical investigation on the problem of oil-gas formation [in Russian]: Trudy Inst. Geologiya i Geofiziki, no. 512, p. 120-132 (English summary in Petroleum Geology, v. 20, no. 8, 1984, p. 391-394).

Aleinikov, A.L., Bellavin, O.V., Bulashevich, Yu.P., Tavrin, I.F., Maksimov, E.M., Rudkevich, M.Ya., Nalivkin, V.D., Shablinskaya, N.V., and Surkov, V.S., 1980, Dynamics of the Russian and West Siberian Platforms, in Dynamics of Plate Interiors, A.W. Bally, et al, eds.: American Geophysical Union and Geol. Soc. of America, p. 53-71.

Aleksin, A.G., Afanas'yev, Yu.T., Kornev, B.V., and Pogorelov, B.S., 1975, 0ilgas prospects of the pre-Jurassic formations of West Siberia: [in Russian]: Neftegazovaya Geologiya i Geofizika, no. 7, p. 6-10 (English summary in Petroleum Geology, v. 12, no. 12, 1975, p. 573-574).

Aplonov, S.V., 1986, A hypothetical Early Mesozoic paleo-ocean in the northern section of the West Siberian Lowland: Oceanology, v. 26, no. 3, p. $346-$ 350 .

Artyushkov, E.V., and Baer, M.A., 1986, Mechanism of formation of hydrocarbon basins: the West Siberia, Volga-Urals, Timan-Pechora basins and the Permian basin of Texas: Tectonophysics, v. 122, p. 247-281.

Badmayev, G.D., Shibayev, V.G., Ishayev, U.G., and Artemenko, V.G., 1982, New oil pools in Bystrin Field of West Siberia [in Russian]: Neftegazovaya Geologiya i Geofiziki, no. 1, p. 27-30 (English summary in Petroleum Geology, v. 19, no. 7, 1983, p. 329-330).

Bayanov, A.S., Boyar, A.G., Lev, S.I., Popovich, N.N., and Rogezhnikov, G.B., 1977, Some new data on the tectonics of the Middle Ob region [in Russian]: ZapSibNIGNI, no. 125, p. 56-61 (English summary in Petroleum Geology, v. 18 , no. 8,1982, p. $385-387)$.

Belkin, V.I., Yefremov, Ye.P., Kaptelinin, N.D., 1983, Model of oil reservoirs of Bazhenov Formation of Salym Field [in Russian]: Neftyanoye Khozyaystvo, no. 10, p. 27-31 (English summary in Petroleum Geology, v. 20, no. 4, 1984 , p. 179-182).

Benenson, V.A., 1983, Pre-Jurassic structural stages of the West Siberian platform in the light of new geological-geophysical information: Moscow, 
Nedra, p. 77-87 (English summary in Fetroleum Geology, v. 20, no. 7, p. $326-328$ ).

Bespalova, S.N., 1981, Gases dissolved in waters of the Jurassic sediments of the north of West Siberia: Geologyia Nefti i Gaza, no. 9, p. 21-26 (English summary in Petroleum Geology, v. 19, no. 9, 1981, McLean, VA, p. 447-451).

Beznosov, T.N., Gorbatchik, T.N., Mikhailova, I.A., and Pergament, M.A., 1978, Soviet Union, in Moullade, M. and Nairu, A.E.M., The Phanerozoic geology of the World II, The Mesozoic, A: Elsenes, NY, p. 5-53.

Binshtok, M.M., 1980, Geologic prediction and outlining lithologic traps in Neocomian sediments of West Siberia by seismic surveying [in Russian]: Geol. Nefti i Gaza, no. 7, p. 18-21 (English summary in Petroleum Geology, v. 18 , no. 7,1982, p. 311-313).

Burakov, V.K., 1982, Oil-gas prospects of the intermediate complex of the West Siberian platform: Neftegazovaya Geologiya i Geofizika, no. 1, p. 21-23 (English summary in Petroleum Geology, v. 19, no. 7, 1983, p. 326-328).

Burakov, V.K., Besprozvannyy, P.A., and Slavkin, V.S., 1980, Experience in plotting the relief of the base of the platform cover of the Middle $\mathrm{Ob}$ area [in Russian]: Neftegazovaya Geologiya i Geofizika, no. 10, p. 10-13 (English summary in Petroleum Geology, v. 18, no. 4, 1982, p. 149-151).

Clarke, J.W., Girard, O.W., Jr., Peterson, J.A., and Rachlin, J., 1977, Petroleum geology of the West Siberian Basin and detailed description of the Samotlor oil field: U.S. Geological Survey, Open-File Report 77-871, 136 p., 49 figs.

, 1978, Petroleum geology of West Siberian Basin and Samotlor oil field: 0i1 and Gas Journal, May 8, 1978, p. 311-328.

Clarke, J.W. and Rachlin, J., 1980, Salym: potential W. Siberian oil giant: 0il and Gas Journal, June 16, p. 132-135.

, 1980, Salym - potential giant oil field in West Siberia; possible reservoir stimulation experiment using a nuclear explosion: USGS, OpenFile Report 80-145, 14 p.

Clarke, J.W., 1984, Petroleum geology of western part of West Siberia: USGS, Administrative Report, $52 \mathrm{p}$.

Dazakov, A.M., Dagis, A.S., and Kurushin, N.I., 1982, Paleogeography of the Triassic of the north of middle Siberia [in Russian]: Trudy Inst. Geologii i Geofiziki, no. 514, p. 54-75 (English summary in Petroleum Geology, v. 20 , no. 7,1984, p. $333-338$ )

Dorofeyeva, T.V. and Krasnov, S.G., 1983, Post-sedimentational alteration of Bazhenov rocks [in Russian]: in Kollektory nefti Bazhenovskoy svita 
Sanadnoy Sibiri; Leningrad, Nedra, Trudy VNIGRI, p. 26-40 (English summary in Petroleum Geology, v. 20, no. 8-, 1984), p. 374-376)

Dorofeyeva, T.V., Lebedev, B.A., and Petrova, G.V., 1979, Features of development of reservoir properties of the Bazhenov Formation of Salym Field [in Russian]: Geol. Nefti i Gaza., no. 9, p. 20-23 (English summary in Petroleum Geology, v. 17, no. 9, 1981, p. 418-419)

Dorofeyeva, T.V., 1980, Characteristics of formation of capacity in rocks of the Bazhenov Formation [in Russian]: Neftegazovaya Geol. I Geofizika, no. 11, p. 33-35 (English summary in Petroleum Geology, v. 18, no. 5, 1982, p. $212-214$ )

Du Rocket, J., 1980, A paleoclimatic explanation for the giant gas reserves of northern West Siberia: Bulletin des Centres de Redverdres Exploration Production Elf-Aquitaine, v. 4, no. 1.

Fain, Yu.B., and Bikbulatov, B.M., 1975, Oil prospects of the pre-Jurassic formations in West Siberia [in Russian]: Geol. Nefti i Gaza, no. 2, p. 8 11 (English summary in Petroleum Geology, v. 13, no. 2, 1976, p. 61-62)

Fain, Yu.B., Pogonyaylov, V.G., and Bikbulatov, B.M., 1977, Exploration for oil and gas in West Siberia [in Russian]: Neftegazovaya Geologiya i Geofizika, no. 2, p. 12-14 (English summary in Petroleum Geology, v. 14, no. 9, 1977, p. 379)

Filina, S.I., 1974, Deltaic and fore-deltaic facies of the Jurassic sediments of the Middle ob region as exploration targets [in Russian]: Neftegazovaya Geologiya i Geofizika, no. 11, p. 21-24 (English summary in Petroleum Geology, v. 12, no. 5, p. 243-248).

Fomin, A. N., 1987, Catagenesis and nature of dispersed organic matter in preJurassic sediments in the southeast of the West Siberian platform [in Russian]: Geologiya i Geofizika, no. 3, p. 27-33.

Generalov, P.P., 1983, Late Cenozoic appearance of compressive folding and displacement dislocation in West Siberia [in Russian]: in Regional'naya neotektonika Sibiri: Novosibirsk, Nauka, p. 15-25 (English summary in Petroleum Geology, v. 20, no. 8, 1984, p. 354-357).

Gogonekov, G. N., Mikhaylov, Yu. A., and El'manovich, SS, 1988, Analysis of Neocomian clinoforms of West Siberia from seismic data [in Russian]: Geologiya Nefti i Gaza, no. 1, p. 22-30.

Gol'dberg, I.S., Zelichenko, I.A., and Chernikov, K.A., 1976, Conditions for the appearance of the main phase of oil formation in clastic rocks of the Mesozoic and Paleozoic [in Russian]: Geol. Nefti i Gaza, no. 3, p. 57-63 (English summary in Petroleum Geology, v. 14, no. 3, 1977, p. 135-137).

Golionko, G.B., 1982, Some problems of the tectonics of the central part of the West Siberian Plate: Intl. Geol. Rev., v. 24, no. 7, p. 780-784. 
Goncharov, I.V., Lugovik:, B.A., Kulachenko, V.I., and Nemirovskaya, G. B., 1979, Study of the composition of isomer phenols in West Siberia oils [in Russian]: Geologiy'a Nefti i Gaza, no. 7, p. 19-21 (English summary in Petroleum Geology, v. 17, no. 7, 1981, p. 315-317).

Grace, John D., and Hart:, George F., 1986, Giant gas fields of northern West Siberia: American Association of Petroleum Geologists Bulletin, v. 70, p. $830-852$.

Gramberg, I.S., Kulakov, Yu.N., Pogrebitskiy, Yu.Ye., and Sokolov, D.S., 1984, Arctic oil-gas suprer-basin [in Russian] in Neftegazonosnos mirovogo okeana: Leningrad, PGO "Sevmorgeologiya," p. 7-21 (English summary in Petroleum Geology, v. 22, no. 3).

Grebenyuk and others, 1982, Vasyugan oil-gas region of West Siberia [in Russian]: in Geolcrgiya SSSR, Ye.A. Kozlovskiy, ed.: Moscow, Nedra, v. 14, book 1, p. 32-36 (English summary in Petroleum Geology, v. 20, no. 10, 1984 , p. 477-480).

Grebenyuk, V.V. and others, 1982, Middle ob oil-gas region [in Russian]: in Geologiya SSSR, Yє..A. Kozlovskiy, ed.: Moscow, Nedra, v. 14, book 1, p. 27-28 (English summary in Petroleum Geology, v. 20, no. 10, 1984, p. 469471).

Grigor'yeva, G.F., Badryzlova, R.A., Semenova, L.A., and Krapivina, N.I., 1980, Variation in oil-source potential of organic matter in Mesozoic sediments of West Siberia [in Russian]: Trudy ZapSibNIGNI, no. 157, p. 23-38

(English summary in Petroleum Geology, v. 20, no. 6, 1984, p. 279-281).

Gurari, F.G., 1981, Poo].s of hydrocarbons in clayey rocks [in Russian]: Trudy Inst. Geologii i Ceofiziki, no. 513, p. 105-116 (English summary in Petroleum Geology, v. 20, no. 2, 1984, p. 89-91).

Gurari, F.G., and Trushkova, L. Ya, 1972, Stratigrafiya produktivnykh otlozheniy [Stratigraphy of the productive sediment]: Trudy Akad. Nauk SSSR, Sibirskoya Otdeleriye, Inst. Geologii i Geofiziki, no. 131, p. 7-34.

, 1979, Conditions of deposition and oil productivity of the Bazhenov Formation of West Siberia [in Russian]: Trudy SNIIGGiMSa, no. 271, p. 153159 (English summary in Petroleum Geology, v. 17, no. 8, 1981. p. 380382).

Hamilton, W., 1970, The Uralides and motion of the Russian and Siberian Platforms: Geol. Sioc. America Bull. v. 81, p. 1553-2576.

Ibragimova, T.A., Nelyutiin, V.V., Ostrovskaya, K.V., and P'Yankov, B.N., 1976, Geologic-Hydrogeo]ogic conditions in the Yamburg gas condensate field [in Russian]: Neftegaz:ovaya Geologiya i Geofizika, no. 6, p. 24-26 (English summary in Petroletum Geology, v. 14, no. 1, 1977, p. 15). 
International Petroleum Encyclopedia: Tulsa, Pennwell Publishing Co., vol. 20, 1987.

Ishayev, U.G., Kornen, B.V., Kozlova, M.I., and Sokolova, T.N., 1976, Dil-gas prospects of the Lokosov downwarp of West Siberia [in Russian]:

Neftegazovaya Geologiya i Geofizika, no. 3, p. 3-5 (English summary in Petroleum Geology, v. 13, no. 8, 1976, p. 331-332).

Kalinko, M.K., 1982, Geologic conditions for formation of gas-condensate pools of various genetic types [in Russian]: Trudy VNIGNI, no. 240, p. 5-17

(English summary in Petroleum Geology, v. 20, no. 9, 1984, p. 395-397).

Kazais, V.I., and others, 1984, Possibility of direct exploration for hydrocarbon pools in Neocomian-Upper Jurassic sediments of the YeniseyKhatanga downwarp: Petroleum Geology, v. 22, no. 5, p. 187-189.

Kazarinov, V.V., 1983, Organic matter of the Bazhenov Formation of the West Siberian Platform [in Russian]: Sovetskaya Geologiya, no. 5, p. 25-35 (English summary in Petroleum Geology, v. 20, no. 1, 1984, p. 30-31).

Kedrovskiy, O.L., Musinov, V.I., Krynitskiy, V.G., 1980, Completion of oil and gas pools in low-permeable reservoirs [in Russian]: Geolgiya Nefti i Gaza, no. 11, p. $43-46$ (English summary in Petroleum Geology, v. 18, no. 11, 1982 , p. 523-524).

Khabarov, V.V., Nelepchenko, O.M., Volkov, Y.N., and Bartashevich, O.V., 1980, Uranium, potassium, and thorium in bituminous rocks of the Bazhenov Formation of West Siberia [in Russian]: Sovetskaya Geologiya, no. 10, p. 94-105 (English summary in Petroleum Geology, v. 17, no. 8, 1981, p. 383390.

Khain, V.Ye., 1979, Regional geotectonics, Outer-Alpine Asia and Australia [in Russian]: Moscow, Nedra, 355 p.

Khain, V.Ye., Ronov, A.B., and Balukhovskiy, A.N., 19? , Cretaceous lithologic associations of the world: International Geology Review, v. 18, no. 11, p. $1269-1295$.

Kirschvink, Joseph L, and Rozanov, A. Yu., 1984, Magnetostratigraphy of lower Cambrian strata from the siboxian platform: a paleomagnetic pole and a preliminary polarity time-scale: Geological Magazine, v. 121, p. 189-203.

K1imushina, L.P., and Medvedeva, A.M., 1982, Palynological analysis of oils of Samotlor Field [in Russian]: Neftegazovaya Geol. i Geofizika, no. 8, p. 8 11 (English summary in Petroleum Geology, v. 20, no. 2, 1984, p. 53-55).

Klubova, T.T., and Kas'yanova, N.M., 1982, Mineral composition and thermoanalytical indexes of rocks of the Bazhenov Formation of West Siberia: in Migratsiya uglevodorodov i usloviya ormirovaniya kollektorov nefti: Moscow, Nedra, p. 109-114 (English summary in Petroleum Geology, v. 20, no. 6,1984, p. 270-272). 
Kolgina, L.P., Syngayevskaya, T.P., and Chernova, N.A., 1982, Composition of rock reservoirs ard their distribution in productive sediments of the Arkticheskaya Fiel.d of the Yamal Peninsula [in Russian]: in Migratsiya uglevodorodov i us loviya formirovaniya kollektorov nefti: Moscow, Nedra, p. 56-61 (English summary in Petroleum Geology, v. 20, no. 6, 1984, p. $256-258$ ).

Konovalov, Yu.G. and Glukhoyedov, Yu.M., 1977, Characteristics of the subsurface geology and history of development of the Urengoy mega-arch [in Russian]: Trudy ZapSibNIGNI, no. 125, p. 74-79 (English summary in Petroleum Geology, v. 18, no. 9, 1982, p. 434-436).

Kontorovich, A.E. and others, 1975, Geology of oil and gas of West Siberia [in Russian]: Moscow, Nedra, 679 p.

, 1983, Composition of oils of the West Siberian oil-gas province [in Russian]: Trudy, VNIGNI, no. 244, p. 54-59 (English summary in Petroleum Geology, v. 20, no. 8, p. 390).

Kornev, B.V., Fain, Yu.B., Ishayev, U.G., Kozlova, M.I., and Bikbulatov, B.M., 1976, Main results of geological exploration in the commercial regions of West Siberia in 1971-75 and future plans [in Russian]: Neftegazovaya Geologiya i Geofizika, no. 8, p. 16-18 (English summary in Petroleum Geology, v. 14, no. 3, 1977, p. 99-100).

Kornev, B.V., Nikonov, V.F., Sulima, S.A., and Yakovlev, G.G., 1982, Zonality of hydrocarbon deposits of West Siberia according to phase state [in Russian]: Nedra, p. 118-125 (English surmary in Petroleum Geology, v. 20, no. 6,1984, p. $273-275$ ).

Korofeyeva, T.V., Krasnov, S.G., and Lebedev, B.A., 1983, Reservoir properties of rocks of the Bazhenov Formation [in Russian]: in Kollektory nefti Bazhenovskoy svita Zapadnoy Sibiri: Leningrad, Nedra, Trudy VNIGRI, P. 6574 (English summary in Petroleum Geology, v. 20, no. 8, 1984, p. 377-379).

Krasnov, S.G., and Lebediev, B.A., 1982, $0 i 1$ of the Bazhenov Formation [in Russian]: Priroda, no. 8, p. 80-85, (English summary in Petroleum Geology, v. 19 , no. 9,1983, p. $452-455)$.

Krasnov, S.G., Dorofeyevia, T.V., and Lebedev, B.A., 1983, Oil and gas fields of the "Bazhenov" type in some sedimentary basins of the world, [in Russian], in Kollektory Nefty Bazhenov svity Zapadnoy Sibiri: Leningrad, Nedra, Trudy VNIGRI, p. 104-120 (English summary in Petroleum Geology, v. 20, no. 8,1984 , P. $380-38:$ ).

Krasnov, S.G., 1983, Conditions for oil occurrence in Bazhenov Formation [in Russian], in Kolleltory nefti Bazhenovskoy svity Zapadnoy Sibiri:

Leningrad, Nedra, :.rudy VNIGRI, p. 17-26 (English summary in Petroleum Geology, v. 20, no 8, 1984, p. 370-373). 
Krylov, N.A., Orel, V.Ye. and Filina, S.I., 1980, 0il-producing capacity of rocks of the Bazhenov Formation [in Russian]: Neftegazovaya Geol. i Geofizika, no. 8, p. 15-17 (English summary in Petroleum Geology, v. 18, no. 2,1982 , p. $58-60$ ).

Krylov, N.A., and others, 1981, 0il-gas potential of pre-Jurassic rocks of West Siberia [in Russian], in Perspektivy neftegaznosnosti doyurskikh otlozheniy molodykh platform: Moscow, Nauka, p. 128-140 (English summary in Petroleum Geology, v. 20, no. 10, 1984, p. 459-461).

Krylov, N.A., and others, 1981a, Transition Complex of West Siberia [in Russian]: Moscow, Nauka, p. 45-49 (English summary in Petroleum Geology, v. 20 , no. 10, p. $452-453)$.

Krylov, N.A., and others, 1981b, Reservoir properties of Permo-Triassic sediments of West Siberia [in Russian]: Moscow, Nauka, p. 94-99 (English summary in Petroleum Geology, p. 20, no. 10, p. 457-458).

Krylov, N.A., and others, 1981c, State of study of pre-Jurassic of West Siberia: Moscow, Nauka, p. 14-16 (English summary in Petroleum Geology, v. 20, no. 10 , p. $450-451$ ).

Krylov, N.A., and others, 1983, Tectonics of the pre-Jurassic sediments of West Siberia: Moscow, Nauka, p. 77-83 (English summary in Petroleum Geology, v. 20 , no. 10, p. 454-456).

Kulikov, P.K., Belousov, A.P., and Latypov, A.A., 1972, West Siberian Triassic rift System: Tectonophysics, v. 6, p. 367-371.

Kunin, N.Ya., and Krasil'nilova, T.B., 1976, Constructions by comparison with drilling data in the Samotlor Field [in Russian]: in Neftegazovaya Geologiya i Geofizika, no. 10, p. 37-41 (English summary in Petroleum Geology, v. 14, no. 5, 1977, p. 201-203).

Kunin, N.Ya. and Krasil'nikova, 1980, Method of probability - analytical prediction of number and dimensions of anticlines favorable for oil and gas in platform regions [in Russian]: Geologiya Nefti i Gaza, no. 4, p. 15-22 (English summary in Petroleum Geology, v. 18, no. 4, p. 171-173).

Kuzin, I.L., 1983, Effect of recent tectonic movements, oscillations of sea level, and climate changes on the formation of oil and gas fields in West Siberia [in Russian]: in Regional'nata neotektonika, Sibiri: Novosibirsk, Nauka, p. 26-31 (English summary in Petroleum Geology, v. 20, no. 8, 1984, p. $358-360)$.

Lebedev, B.A., and Krasnov, S.G., 1983, Geological and geochemical characteristics of the Bazhenov Formation [in Russian]: Nedra, Trudy VNIGRI, p. 6-17 (English summary in Petroleum Geology, v. 20, no. 8, 1984, p. $365-369)$. 
Levchuk, M.A., and Fomin, A.N., 1983, Catagenesis of Jurassic sediments of the east part of the Yenisey-Khatanga downwarp [in Russian]: Akad, Nauk SSSR, Sibir. Otdel., Trudy Inst. Geol. i Geof., no. 532, p. 123-131 (English summary in Petroleum Geology, v. 19, no. 12, 1983, p. 599-601).

Litbakov, V.U., and Mukhametzyanov, R.N., 1976, New data on the geology of the oil pools of horizon $\mathrm{AB}_{4-5}$ of the Samotlor Field [in Russian]:

Neftegazovaya Geologiyai Geofizika, no. 5, p. 26-28 (English summary in Petroleum Geology, v. 13, no. 11, 1976, p. 519-520).

Lugovtsov, A.D. and Moskvin, V.I., 1980, Characteristics of formation of zones of oil-gas accumulation in Jurassic-Cretaceous sediments of the YeniseyKatanga regional downwarp: Geologiya Nefti i Gaza, no. 4, p. 10-15 (English summary in Petroleum Geology, v. 18, no. 4, 1982, p. 168-170).

Lydolph, P.E., 1977, Sone characteristics of the climate of the USSR with a direct bearing on human activity, in Soviet Geography: Review and Translation: American Geographical Society, p. 145-162.

Lysyanskiy, A.V., 1981, Geologic characteristics of horizon BV10 of Samotlor oil-gas field [in Russian]: Neftegazovaya Geologiya i Geofizika, no. 6, p. 11-13 (English summary in Petroleum Geology, v. 18, no. 11, 1982, p. 543546).

Maksimov, Ye.M., and Rulkevich, M.Ya., 1971, Quantitative evaluation of the dynamics of Mesoziic and Cenozoic vertical movements over the West Siberian plate: Geotectonics, v. 3, p. 245-248.

Maksimov, S.P., and Dekenshteyn, G.Kh., 1979, Age of the folded base of the West Siberian platform and possible distribution of oil-gas complexes within it: Geologiya Nef1:i i Gaza, no. 7, p. 6-11 (English summary in Petroleum Geology, v. 17, no. 7, p. 306-308.)

Maksimov, S.P., Sazonov, M.L., Kramarenko, G.A., and Selenkina, M ., 1980, New geochemical criterion for investigation of conditions of formation of hydrocarbon accumulations [in Russian]: Geologiya Nefti i Gaza, no. 8, p. 26-32 (English sunmary in Petroleum Geology, v. 18, no. 8, 1982, p. 375$377)$.

Maksimov, S.P., Zolotov, A.N., and Lodzhevskaya, M.I., 1984, Tectonic conditions for oil and gas generation and distribution on ancient platforms: Journal of Petroleum Geolcgy, v. 7, no. 3, p. 329-340.

Maksimov, S.P., Brindzirıkiy, A.M., Kramarenko, G.A. and Takayey, Yu.G., 1981, Conditions of formation of gas-condensate fields and prediction of condensate content: in the subsurface of West Siberia [in Russian]: VNIGNI, no. 229, p. 3-11 (English summary in Petroleum Geology, v. 19, no. 4, 1983, p. 206-208).

Maksimov, S.P. and others, 1987, 0il and gas fields of the USSR [in Russian]: Moscow, Nedra, v. 2, 303 p. 
Mamleyev, R.Sh., Chechin, F.A., Salmanov, F.K., and Tyan, A.V., 1976, Prospects for exploration for non-anticlinal pools of oil and gas in the Surgut oilgas region [in Russian]: Geologiya Nefti i Gaza, no. 7, p. 13-16 (English summary in Petroleum Geology, v. 14, no. 7, 1977, p. 306-307).

Markovskiy, N.I., 1978, Paleogeographic principles of oil and gas prospecting: Wiley \& Sons, NY, $270 \mathrm{p}$.

Markovskiy, N.I., 1981, Influence of an ancient river network on formation of accumulations of oil and gas in Western Siberia: Intl. Geol. Rev., v. 23, no. 7, p. $781-784$.

Maslennikov, V.V., Khannanov, Z.D., and Akhmadeyeva, Z.A., 1980, Structure of the oil ring in horizon BU10-11 of Urengoy gas-condensate-oil field [in Russian]: Neftegazovaya Geol. i Geofizika, no. 10, p. 22-26 (English summary in Petroleum Geology, v. 18, no. 4, 1982, p. 162-165).

Matusevich, V.M., Prokop'yeva, R.G., and Bespalova, S.N., 1984, Hydrogeochemical basis for oil-gas prospects of deep horizons in the north of West Siberia [in Russian]: Neft i Gaz, no. 1, p. 3-7 (English summary in Petroleum Geology, v. 20, no. 12, 1984, p. 576-577).

Matviyenko, V.N., 1975, Comparative characteristics of geothermal conditions in some fields of West Siberia [in Russian]: Neftegazovaya Geologiya i Geofizika, no. 10, p. 12-14 (English summary in Petroleum Geology, v. 13, no. 2,1976, p. 53-54).

Melik-Pashayev, V.S., 1976, Increase in gas content of the oil-bearing formations of the Neocomian in a north direction in fields of the Middle Ob oil region [in Russian]: Geologiya Nefti i Gaza, no. 3, p. 1-5 (English summary in Petroleum Geology, v. 14, no. 3, p. 114-115).

Meyerhoff, A.A., 1980, Petroleum basins of the Soviet Arctic: Geological Magazine, v. 17, p. 101-186.

, 1981, Energy base of the Communist-socialist countries: American Scientists, v. 69, p. 624-631.

Myachnikova, G.P., and Yasovich, G.S., 1977, Geologic features of the oil pool of stratum $\mathrm{Jl}$ in the Ur'Yev and Potoch areas in connection with its final outlining [in Russian]: Trudy ZapSibNIGNI, no. 120, p. 21-23 (English summary in Petroleum Geology, v. 17, no. 3, 1981, p. 127-128).

Nakaryakov, V.D., Vasil'yeva, K.N., Ivanov, A.M., Kucherov, V.Yę., Sibgatullin, V.G., and Sharygin, Yu.A., 1980, Structural features of the platform cover of the western part of the Siberian platform in connection with evaluating prospects for oil and gas: [in Russian]: Tektonika Sibiri, vol. IX, Nauka, Novosibirsk, p. 49-55 (English summary in Petroleum Geology, v. 20, no. 1, 1984, p. 39-41). 
Nalivkin, D.V., 1960, Geological framework and oil and gas possibilities of the northern part of the West Siberian Lowland: Intl. Geol. Cong., Part XI, P. 47-56.

, 1976, Dynamics of the development of the Russian platform structure: Tectonophysics, v. 36, p. 247-262.

National Geographic Society, 1981, Atlas of the World, fifth edition: National Geographic Society, Washington, DC, 383 p.

Naumov, A.L., Onishchuk, T.M., Dyadyak, N.B., Ivashehenko, A.Ye., Romanenkov, V.A., Shipitain, V.V., and Yudin, A.G., 1979, Lithologic pools of hydrocarbons in the north of West Siberia [in Russian]: Geologiya Nefti i Gaza, no. 8, p. 15-20 (English summary in Petroleum Geology, v. 17, no. 8, 1981, p. 363-366).

Nesterov, I.I., Poteriaeva, V.V. and Salmanov, F.K., 1975, Regularities of distribution of major oil and gas fields in the earth's crust: Moscow, Nedra, $280 \mathrm{p}$.

Nesterov, I.I., 1976, Results of oil-gas exploration in the Tyumen region during the ninth Five Year Plan, ways to increase its effectiveness, and tasks for 1976-1980 [in Russian]: Geologiya Nefti i Gaza, no. 1, p. 1-7 (English summary in Petroledm Geology, v. 14, no. 1, 1976, p. 19-20).

Nesterov, I.I., 1979, New type of oil and gas reservoir [in Russian]: Geologiya Nefti i Gaza, no. 10, p. 26-29 (English summary in Petroleum Geology, v. 17 , no. 10,1981 , ?. 476-478).

Nesterov, I.I., Medvedskiy, R.I., and Storozhev, A.D., 1982, Characteristics of producing oil pools in bituminous clays of the Bazhenov Formation [in Russian]: Probl. osvoyeniya Zap. Sib. toplivno-energ. kompleksa. Tez. dokl. I resp. naucla. - tekhn. konf: Ufa, p. 43-44 - abstract only (in Petroleum Geology, v. 19, no. 6, 1983, p. 307-308).

Nesterov, I.I., Tikhomirov, Yu.P., and Stovbyn, Yu.A., 1984, The oil and gas content of the Ure:agoy field Berriasian and Jurassic deposits and problems of studying them [in Russian]: Geologiya Nefti i Gaza, no. 12, p. 9-13.

Nesterov, I.I., Shpil'mai, V.I., Plavnik, G.I., and Suda, L.G., 1985, Petroleum prospects of the Neocomian beds in the Tyumen region: Geologiya nefti i gaza, no. 4, p. $8-13$.

Nikolayev, and others, 1978, Modern fault tectonics of the USSR; International Geological Review, v. 10, no. 10, p. 1115-1124.

Oil and Gas Journal, 1987, Western Siberia will be a key to Soviet plan to boost hydrocarbon produciion: $0 i 1$ and Gas Journal, Dec. 7, 1987, p. 33-40.

Oil and Gas Journal, 1987, Soviets launch horizontal drilling in western Siberia: Oil and Gas Journal, June 15, 1987, p. 26-27. 
Oslrovskaya, T.D., 1976, Prediction of the phase siate of hydrocarbons in West Siberia according to thermodynamics of occurrence of pools [in Russian]: Geologiya Nefti i Gaza, no. 1, p. 44-50 (English summary in Petroleum Geology, v. 14, no. 1, 1977, p. 33-36).

, 1979, Prediction of the content and composition of condensate and condensate recovery for pools in the north of West Siberia: Geologiya Nefti i Gaza, no. 2, p. 33-37 (English summary in Petroleum Geology, v. 17, no. 2, p. 79-82).

Ostryy, G.B., 1967, New data on permanently frozen rocks in the oil and gas regions of West Siberia: Doklady Aked, Nauk SSSR. v. 173, p. 23-25.

Ovanesov, G.P., Abrikosov, I.Kh., Alexin, A.G., Sarkisyah, S.G., Khachatryan, R.O., Alikhanov, E.N., and Pashkov, Yu,V., 1975, Palaeodeltaic sediments and methods of petroleum exploration in the U.S.S.R.: Proceedings, Geology, Ninth World Petroleum Congress, v. 2, p. 229-238.

Ozeranskaya, L.S., Rudkevich, M.Ya., and Svintitskikh, L.Ye., 1979, Geochemical indices of composition of oils reflecting conditions of formation of fields of the Middle Ob region [in Russian]: Geologiya Nefti i Gaza, no. 7, p. 11-14 (English summary in Petroleum Geology, v. 17, no. 7, 1981, p. $309-314)$.

Panchenko, L.T., and Beresnev, N.F., 1980, Character of the oil saturation of the reservoirs of the Middle Ob oil-gas province [in Russian]: Geologiya Nefti i Gaza, no. 6, p. 10-14 (English summary in Petroleum Geology, v. 18 , no. 6, 1982, p. 257-260).

Pavlenkov, A.I., Strakhov, A.N., Yefanov, V.Ya., and Kondrashov, V.A., 1975, Tectonics of the Paleozoic sediments of the Nyurol depression based on seismic survey data (as related to estimating oil-gas potential), in Tectonics of oil-gas areas of Siberia [in Russian]: Trudy SNIGGIMS, no. 217, p. 42-47 (English summary in Petroleum Geology, v. 14, no. 6, 1977 , p. $277-278$ ).

Polyakova, I.D., Soboleva, Ye.I., and Stepanenko, G.F., 1983, Intensity of emigration of liquid hydrocarbons and of generation of gas hydrocarbons from oil-gas-bearing complexes of the Khatanga-Vilyuy oil-gas province [in Russian]: Akad. Nauk SSSR, Sibir. Otdel., Trudy Inst. Geol. i Geof. no. 532, p. 140-147 (English summary in Petroleum Geology, v. 19, no. 12, 1983, p. 606-609).

Prasolov, E.M., Kamenskiy, I.L., Meshik, A.P., Subbotin, Ye.S., Surovtseva, L.N., and Yakovkev, O.N., 1981, Formation of gas fields of the north of West Siberia from isotope data, in Proiskhozhdeniye $i$ formirovaniye sostav prirodnykh gazov po dannym isotopnoy geokhimii [in Russian]: Leningrad, VNIGRI, p. 64-82 (English summary in Petroleum Geology, v. 20, no. 7 , 1984, p. 316-319). 
Protsvetalova, T.N., 1983, Lower Cretaceous stratigraphic oil- and gas-bearing complexes of the liest Siberian Platform: International Geological Review, v. 25 , no. 4, p. 447-454.

Radchenko, 0.A., 1965, Geochemical regularities in the distribution of the oilbearing regions of the world: Nedra (trans1. in Israel Program for Scientific Translations, Jerusalem, 1968).

Ragozin, L.A., 1984, Tectonic episodes during the neotectonic stage in Western Siberia: Geotectonics, v. 18, p. 525-533.

Rigassi, D.A., 1986, Wrench faults as a factor controlling petroleum occurrences in West Siberia, in Future petroleum provinces of the world: Tulsa, American Association of Petroleum Geologists, p. 529-544.

Ronkina, Z.Z., and Bro, Ye.G., 1984, Lithologic-paleogeographic characteristics of Jurassic-Cretaceous sediments of Kara sedimentation sub-basin [in Russian]: in Neftegazonosnost mirovogo okeana: Leningrad, PGO "Sevmorgeolo-giya," p. 48-59 (English summary in Petroleum Geology, v. 22, no. 3).

Rozhenas, S.M., 1974, Problems of the geochemistry of the oil-gas-condensate pools of the north of the West Siberian Plate [in Russian]: Geologiya Nefti i Gaza, no. 5 , p. 26-31 (English summary in Petroleum Geology, $v$. 12 , no. 5, 1975, p. 227-229).

Rudkevich, M.Ya., 1970, Atlas of structure, paleotectonic, and geologic maps of the West Siberian Jowland: Tyamen, Zap Sib NIGNI, 1:5,000,000, 17 sheets.

Rudkevich, M.Ya., 1976, The history and the dynamics of the development of the West Siberian plat:iorm: Tectonophysics, v. 36, p. 275-287.

Rudkevich, M.Ya., 1981, Structural lithofacies regionalization of the platform cover of the West Siberian Platform, in Neftegazonosnost' Sibiri i Dal'nego Vostoka [:n Russian]: Novosibirsk, Nauka, p. 122-131 (English summary in Petroleum Geology, v. 20, no. 5, 1984?, p. 224-228).

Rudkevich, M.Ya. and Ozel:anskaya, L.S., 1983, Geochemical criteria for formation of oil and oil-gas.condensate fields in the example of the West Siberian oil-gas province, $j_{\text {.n }}$ Osnovyye printsipy formirovaniya zalezhey nefti $i$ gaza: Moscow, Naukaı, p. 94-104.

Rudkevich, M.Ya. and othe:rs, 1988, 0il-gas complexes of the West Siberian basin [in Russian]: Moscciw, Nedra, 304 p.

Ryabukhin, G.Ye., and Byk:ov, V.F., 1974, Prospects for discovery of oil and gas fields in reef masses and reef facies of the USSR [in Russian]: Geologiya Nefti i Caza, no. 7, p. 27-33 (English summary in Petroleum Geology, v. 12, no. 7, 1975, p. 330-) 
Ryzkhova, S.M., 1976, A new type of oils in Western Siberian: Soviet Geoiogy and Geophysics (Geologiya i Geofizika), v. 17, no. 1, p. 122-123.

Salmanov, F.K., Remeyev, O.A., and Khafizov, F.Z., 1979, Favorable directions for oil exploration in the northern parts of the Tyumen region [in Russian]: Geologiya Nefti i Gaza, no. 7, p. 1-5 (English summary in Petroleum Geology; v. 17, no. 7, 1981, p. 304-305).

Salmanov, F.K., and Khafizov, F.Z., 1984, The results of geological activity in 1981-83 and the main directions for geological exploration: Geologiya Nefti i Gaza, no. 3, p. 1-6.

Sanin, V.P., Svishchev, M.F., and Baturin, Yu.Ye., 1976, Standardized values of parameters of productive strata and of oil reserves of fields of West Siberia [in Russian]: Geologiya Nefti i Gaza, no. 8, p. 46-50 (English summary in Petroleum Geology, v. 14, no. 8, 1977, p. 358-359).

Sarayeva, G.D., and Khanin, A.A., 1975, Main type of rock reservoirs of the Urengoy and Medvezh'ye fields [in Russian]: Geologiya Nefti i Gaza, no. 3, p. 57-61 (English summary in Petroleum Geology, v. 13, no. 3, 1976, p. $130-132)$.

Sevost'yanov, K.M., 1980, Oil-gas prospects of pre-Jurassic rocks in the West Siberian mega-depression [in Russian]: Geologiya Nefti i Gaza, no. 11, p. 33-39 (translation in International Geological Review, v. 24, no. 2, p. $190-196,1982)$.

Sergiyenko, S.I., 1978, Influence of the thermal field on oil-gas content of Mesozoic rocks of the West Siberian platform: International Geological Review, v. 20, no. 9, p. 1102-1110.

Shardanov, A.N., 1983, Lower structural complexes of the sedimentary cover of platforms and their oil-gas potential [in Russian]:_?i_?n

Neftegazonosnost' nizhnikh strukturnykh etazhey chekh'la platform [in Russian]: Moscow, Nauka, p. 19-27 (English summary in Petroleum Geology, v. 20 , no. 8,1981, p. $320-324)$.

Shchepetkin, Yu,V., 1978, Recommendations for final outlining of pools in stratum BS10 of Fedorovo Field and the Surgut area in the light of new data [in Russian]: Trudy ZapSibNIGNI, no. 120, p. 86-89 (English summary in Petroleum Geology, v. 17, no. 3, 1981, p. 133-134).

, 1980, Prediction of oil-gas productivity of local highs of the Middle ob region taking into account stage formation of fields [in Russian]: Trudy ZapSibNIGNI, no. 157, p. 123-130 (English summary in Petroleum Geology, v. 18 , no. 7,1982, p. 341-343).

Shimanskiy, V.K., Shapiro, A.I., and Ivantsova, V.V., 1976, Regularities in individual composition of arenes C6 - C10 of low-boiling fractions of disseminated organic matter of rocks of West Siberia [in Russian]: 
Geologiya Nefti i Gaza no. 4, p. 69-75 (English summary in Petroleum Geology, v. 14, no. 4, 1977, p. 172-177).

Shipitsyn, V.V., Naumov, A.L., and Onishchuk, T.M., 1979, Lithologic traps -oil exploration targets in the Nadym-Pur oil-gas region [in Russian]: Neftegazovaya Geologiya i Geofizika, no. 8, p. 3-3 (English summary in Petroleum Geology, v. 17, no. 2, 1981, p. 43-47).

Shnip, O.A., Gibshman, N.B., and Vasil'yeva, M.Yu., 1981, Paleozoic carbonate section of the southeast part of West Siberia: Neftegazovaya Geologiya i Geofizika, no. 7, p. 17-18 (English summary in Petroleum Geology, v. 19, no. 1,1983, p. $12-13$, McLean, VA).

Sidorenkov, A.I., and Vysotskiy, V.N., 1977, Determination of direction of pinchout of lithologic traps using concretion analysis at early stages of outlining of oil pools in West Siberia [in Russian]: Trudy ZapSibNIGNI, no. 120, p. 83-86 (English summary in Petroleum Geology, v. 17, no. 3, 1981$, p. $131-132)$.

Skorobogatov, V.A., 1980, Conditions of formation of hydrocarbon accumulations in Upper Jurassic sediments of the central and northern regions of West Siberia [in Russian]: Geologiya Nefti i Gaza, no. 11, p. 25-32 (English summary in Petroleam Geology, v. 18, no. 11, 1982, p. 516-518).

, 1984, The oil ac:umulation conditions in the Krasnoleninskaya zone (Western Siberia): Sovetskaya Geologiya, no. 9, p. 3-13.

, 1984a, Certain criteria for prospects that the Bozhenov Formation of West Siberia bears oil: Geologiya Nefti i Gazi, no. 3, p. 15-19.

Slavkin, V.S., Burakov, J.K., and Zin'kovskiy, V.Ye., 1980, Experience in the use of ASCINT for the eastern part of the Surgut arch [in Russian]:

Neftegazovaya Geologiya i Geofizika, no. 10, p. 39-40 (English summary in Petroleum Geology, v. 18, no. 4, 1982, p. 166-167).

Smirnov, G.A., Tectonic development of the Urals, from a study of the lithofacies: Geoteiztonics, no. 2, p. 78-82.

Sokolovskiy, A.P., Deshchenya, N.P., and Ramazanova, S.F., 1977, Oil productivity of st:catum J1 on the southwest flank of the Nizhne-Vartov Arch [in Russian]: Trudy ZapSibNIGNI, no. 120, p. 24-26, 1977 (English summary in Petroleim Geology, v. 17, no. 3, 1981, p. 129-130).

Starkovskaya, A.I., 1981, Isotopes of sulfur in oils of West Siberia [in Russian]: Sbornik lvauchnykh Trudov SNIGGIMS, no. 288, p. 65-70, 1981; English summary in Petroleum Geology, v. 19, no. 9, 1983, p. 460-462).

Stroganov, V.P., 1975, Characteristics of gas generation based on data of the gas content of fornation waters [in Russian]: Neftegazovaya Geologiya i Geofizika, no. 7, P. 25-29 (English summary in Petroleum Geology, v. 12, no. 12,1975, p. 5(32-583). 
Stroganov, V.P., 1976, Conditions of formation of oil pools in Jurassic and Lower Cretaceous sediments in the territory of the platform part of the west of central Asia [in Russian]: Geologiya Nefti i Gaza, no. 4, p. 20-26 (English summary in Petroleum Geology, v. 14, no. 4, 1977, p. 162-164).

, 1982, Prediction of oil productivity of deeply subsided Jurassic sediments in the north of West Siberia [in Russian]: Neftegazovaya Geologiya i Geofizika, no. 6, p. 1-4, (English summary in Petroleum Geology, v. 19, no. 12, 1983, p. 563-565).

Surkov, V.S., and Zhero, O.G., 1981, Basement and development of the platform cover of the West Siberian platform [in Russian]: Moscow, Nedra, v. 20, no. 5, $142 \mathrm{p}$.

Surkov, V.S., Trofimuk, A.A., Zhero, O.G., and Kontorovich, A.E., 1982, The Triassic rift system of the Western Siberian plate and its effect on the structure and the oil and gas potential of the Mesozoic-Cenozoic platform cover [in Russian]: Geologiya i Geofizika, v. 23, no. 8, p. 3-15.

Surkov, V.S., Trofimuk, A.A., Zhero, O.G., Kontorovich, A.E., and Smirnov, L.V., 1983, Prospects for oil exploration in Paleozoic and Lower-Middle Jurassic deposits of the Mansiysk syncline [in Russian]: Geologiya i Geofizika, v. 24 , no. 1 , p. 16-24.

Tal'virskiy, D.B., Guseynov, A.A., Shik, N.S., and Surtsukov, G.V., Galagan, Ye.A., and Kravets, V.M., 1985, Prediction of genetic types of terrigenic deposits on the basis of seismic survey data [in Russian]: Geologiya Nefti i Gaza, No. 1, p. 34-40.

Tamrazyan, G.P., and Ovnatanov, S.T., 1980, Global cyclic distribution of the Earth's gas [in Russian]: Neftegazaovaya Geologiya i Geofizika, no. 12, p. 15-18 (English summary in Petroleum Geology; v. 18, no. 6, p. 245-247).

, 1982, Distribution of deposits of combustible shales in the Soviet Union in relation to their paleo-latitude [in Russian]: Neftegazovaya Geologiya i Geofizika, no. 2, p. 26-29 (English summary in Petroleum Geology, v. 19, no. 8,1983, p. $380-383$ ).

Tolstikhina, M.A., 1971, Cambrian paleotectonics of the USSR: Geotectonics, no. 1, p. $9-15$.

Trofimuk, A.A., and Karogodin, Yu.N., 1981, Bazhenov Formation - a unique natural oil reservoir [in Russian]: Geologiya Nefti i Gaza, no. 4, p. 29 33 (English summary in Petroleum Geology, v. 19, no. 4, 1983, p. 191-192).

Trofimuk, A.A., and Vyshemirskiy, V.S., 1975, Problem of oil productivity of the Paleozoic of the West Siberian Lowland [in Russian]: Geologiya Nefti i Gaza, no. 2, p. 1-7 (English summary in Petroleum Geology, v. 13, no. 2, 1976, p. 59-61). 
Ushatinskiy, I.N., 1980, Characterislics of formation and oil prospects of the Jurassic-Neocomiar, bituminous sediments of West Siberia [in Russian]: Trudy ZapSibNIGNI, no. 157, p. 64-84 (English summary in Petroleum Geology, v. 18, nc. 7, p. 332-340).

Varlamov, I.P., 1983, Results of study of the most recent tectonics of Siberia and evaluation of its oil-gas prospects from neotectonic parameters [in Russian]: in Regional'naya neotektonika Sibiri: Novosibirsk, Nauka, p. 78 87 (English summary in Petroleum Geology, v. 20, no. 8, 1984, p. 361-364).

Veber, V.V., and Kotseruba, L.A., 1979, Environments of bitumen in Bazhenov Formation of West Siberia [in Russian]: Geologiya Nefti i Gaza, no. 9, p. 15-18 (English summary in Petroleum Geology, v. 17, no. 9, 1981, p. 415417).

Vyshemirskiy, V.S., Gontsov, A.A., Krymova, V.N., and Yushina, L.V., 1972, Formation of bitumens in the intermediate tectonic complex of the West Siberian plate [in Russian]: Doklady Akad. Nauk SSSR., v. 210, p. 210-211.

Vyshemirskiy, V.S. and Zapivalov, N.P., 1981, 0il-gas potential of the Paleozoics of the southeast of the West Siberian platform: Tr. Inst. Geologii i Geofiziki, no. 513, p. 99-105 (English summary in Petroleum Geology, v. 20, no. 2, p. 81-87).

Yadrenkina, A.G., Abaimova, G.P., and Sychev, U.V., 1979, Rezones of the Lower Ordovician of the west of the Siberian platform: Trudy SNIIGGIMS, no. 270, p. 110-118 (English summary in Petroleum Geology, p. 19, no. 13, 1983, p. 156-157, McLean, V.A).

Yaroslavov, B.R., P'yankov, B.N., and Radyuk, G.A., 1982, Dynamics of formation pressure for oil fields with fracture reservoirs [in Russian]: in Probl. osvoyeniya Zap. Sib. toplivno-energ. kompleksa. Tez. dokl I Resp. nauch. Tekhn. konf: UFA, p. 49 - abstract only (English summary in Petroleum Geology, v. 19, no. 6, 1983, p. 307).

Yekhanin, A.Ye., Shpil'man, V.I., and Tyan, A.V., 1976, Oil-gas prospects of the north part of the Surgut region [in Russian]: Geologiya Nefti i Gaza, no. 5, p. 13-20 (English summary in Petroleum Geology, v. 14, no. 5, 1977, p. $203-206$ ).

Yermakov, V.I., and Skorsbogatov, V.A., 1976, Oil-gas productivity and ratio of concentrated and disseminated forms of organic matter in the Lower-Middle Jurassic sediments of West Siberia [in Russian]: Geologiya Nefti i Gaza, no. 1, p. 50-54 (English summary in Petroleum Geology, v. 14, no. 1, 1977, p. $36-37)$.

Yermakov, V.I., Skorobogatov, V.A., Leongardt, N.I., and Pashkevich, Ye.I., 1979, Conditions o: formation of hydrocarbon accumulations and oil-gas prospects of deep-occurring horizons in the north of West Siberia [in Russian]: Geologiya Nefti i Gaza, no. 4, p. 11-17, (English summary in Petroleum Geology, v. 17, no. 4, 1981, p. 147-149). 
Yermakov, V.I. and Skorsbogatov, V.A., 1984, Formation of hydrocarbon gises and coal-bearing and sub-coal-bearing complexes: Moscow, Nedra, $160 \mathrm{p}$. (English summary in Petroleum Geology, v. 21, no. 12, p. 531-564).

Zapivalov, N.P., Zubarev, Ye.M., Minko, V.A., Pluman, I.I., Rozhok, N.G., Serdyuk, Z.Ya., and Sherikhora, V.Ya., 1975, Paleozoic oil in the Novosibirsk area [in Russian]: Geologiya Nefti i Gaza, no. 2, p. 14-19 (English summary in Petroleum Geology, v. 13, no. 2, 1976, p. 63-64).

Zapivalov, N.P., Moskovskaya, V.I., and Pluman, I.I., 1980, Tectonics of the Paleozoic oil-gas complex of the south of the West Siberian platform [in Russian]: Tektonika Sibiri, tom 1x, Nauka, Novofirsk, p. 21-23 (English summary in Petroleum Geology, v. 20, no. 1, p. 36-38).

Zapivalov, N.P., 1980, Formation of oilpools in deep Paleozoic carbonates of the intermediate stage in the south of the West Siberian Platform [in Russian]: in Osobennosti formirovaniya zalezhey nefti $i$ gaza $v$ glubokozalegayuschchikh plastakh: Moscow, Nedra, p. 223-228 (English summary in Petroleum Geology, v. 19, no. 6, 1983, p. 292-295).

Zapivalov, N.P., Botneva, T.A., Pankina, R.G., Shulova, N.S., and Guriyeva, S.M., 1980, Geochemical characteristics of Paleozoic and Mesozoic oils of the south of West Siberia [in Russian]: Geologiya Nefti i Gaza, no. 9, p. 8-14, (English summary in Petroleum Geology, v. 18, no. 9, 1982, p. 408410).

Zapivalov, N.P., Pekhtereva, I.A., Serdyuk, Z.Ya., and Shmatalyuk, G.F., 1981 , Identifying and mapping Paleozoic reef massifs in Western Siberia: International Geological Review, v. 23, no. 8, p. 956-962.

Zhabrev, I.P., Zufov, I.P., Krylov, N.A., and Semenoviah, V.V., 1975, Comparative evaluation of the oil and gas potential of the epi-Paleozoic basins of the USSR: Ninth World Petroleum Congress, Proceedings vol. PD2(2), p. 83-91.

Zhabrev, I.P. and others, 1983, Gas and gas condensate fields [in Russian]: Moscow, Nedra, 376 p.

Zhabrev, I.P., Niz'yev, V.A., Akhiyarov, V.Kh., Salmanov, F.K., and Khafizov, F.Z., 1984, Improving the efficiency of operations in Cenomanian fields in northern Tyumen Oblast [in Russian]: Geologiya Nefti i Gaza, no. 10, p. 14.

Zhuravlev, Ye.G., 1984, Tectonic premises for prospecting for oil and gas in pre-Jurassic formations of the West Siberian platform [in Russian]: Geologiya Nefti i Gaza, no. 3, p. 35-39.

Zlotnikov, M.G., Zolotova, M.Ya., Zundelevich, S.M., Sokhranov, N.N., and Tseytlin, V.G., 1980, Computer methods of determination of calculated parameters of oil strata based on logging in fields of the Middle ob 
region [in Russian]: Geologiya Nefti i Gaza, no. 9. p. 1-9, (English summary in Petroleum Geology, v. 18, no. 9, 1982, p. 404-407).

Zonn, M.S., Korzh, M.V., and Filina, S.I., 1976, Prospects for discovery of oil and gas pools in the Jurassic complex of West Siberia [in Russian]: Geologiya Nefti i Gaza, No. 8, p. 6-10, (English summary in Petroleum Geology, v. 14, no. 8, 1977, p. 346-347). 
Appendix B

Data Analysis 



\section{Appendix B}

\section{Data Analysis}

\section{Reservoir Parameters}

Parameters needed for the estimation of oil and gas in place were not available for all reservoirs. Missing data were determined based on analogous data within common areal location and geologic intervals. Fluid properties were calculated for each reservoir using correlations adapted for personal computer spreadsheet software. Unknown reservoir pressures were calculated using an equation for the pressure gradient of the entire basin. Unknown temperatures were determined from separate gradient equations for each of the four Areas of the basin listed in Table 3 .

Distributions of known porosity, permeability, productive area, gross thickness, and net pay along with the distributions of the calculated water saturation for each geologic interval listed in Table $\mathbf{4}$ are shown as Figures 18B through 27B.

\section{Field Location}

Field locations were verified by charting the fields of the basin by latitude and longitude coordinates (Figure 1B). Minor location problems were solved by locating fields on maps or checking several data sources. Regional boundaries are not always distinct; therefore, some fields along the boundaries may be listed in the incorrect Region. Field locations and Region and Area listed in the field summary tables are listed in Appendix D. The location of fields that produce from the geologic intervals of Table 4 are also charted as coordinate graphs of latitude and longitude in Figures 2B - 11B to show the areas of the basin that are productive from the geologic intervals

\section{Reservoir Pressure}

The initial reservoir pressure was calculated for each reservoir that did not have a reported measured pressure. The depth to the reservoir and the pressure gradient of the basin were used in the calculation. The pressure gradient was determined for each Area of the basin. When compared, the gradients were approximately equal so a single gradient for the entire basin was calculated and used to obtain unreported pressures. When no measured pressure was reported, the reservoir depth (usually the top of the pay) was used as the reference depth for calculating the reservoir pressure. Depths were not corrected to a subsea datum is as much as the flat topography reduces most errors of depth measurements within the fields. Errors between fields may be introduced because of the small differences in surface elevations but the errors were considered insignificant. The graph of reported pressures at reservoir depth does not show significant scatter (Figure 12B). The fitted linear equation used to calculate unknown pressures is:

$$
B H P=0.451 * \text { Depth }
$$

Where:

$$
\begin{aligned}
& \text { BHP }=\text { Pressure at reservoir depth }(\mathrm{psi}) \\
& 0.451=\text { Pressure gradient }(\mathrm{psi} / \text { foot) } \\
& \text { Depth }=\text { Depth to reservoir (feet) }
\end{aligned}
$$

\section{Reservoir Temperature}

Linear equations fitted from measured temperatures at reservoir depth were used to calculate unknown reservoir temperatures. Reservoir temperatures vary across the basin so equations were determined for each Area of the basin. Most of the data indicated that a linear equation with a constant of approximately 30 degrees Fahrenheit could be used to calculate reservoir temperature. The equations used for each Area are:

$$
\begin{aligned}
\text { North } B H T & =(0.0152 * \text { Depth })+30 \\
\text { South } B H T & =(0.0197 * \text { Depth })+30 \\
\text { West BHT } & =(0.0241 * \text { Depth })+30 \\
\text { Middle ObBHT } & =(0.0191 * \text { Depth })+30
\end{aligned}
$$

Where:

$$
\begin{aligned}
& \text { Area } \mathrm{BHT}=\text { Temperature at depth in area }\left({ }^{\circ} \mathrm{F}\right. \text {.) } \\
& 0.0 \times x x=\text { Temperature gradient }\left({ }^{\circ} \mathrm{F} \text {./foot }\right) \\
& \text { Depth = Depth to reservoir (feet) } \\
& 30=\text { Constant }
\end{aligned}
$$

\section{Porosity}

For reservoirs with no reported porosity data, porosity was imputed based on a random selection from the observed distribution of porosity in the geologic interval. Reported porosity values ranged from 4 percent to 35 percent. Average values of the geologic intervals ranged between 12 percent and 26 percent. 


\section{Permeability}

The distribution of permeability within each geologic interval was determined and graphed. The mode of the reported permeability of each geologic unit was used where data were not available. Permedbilities ranged from 0.1 millidareys to 1,900 millidarcys. Permeability is used in the calculation of water sturations and recovery efficiencies. 
Figure 1B. Location of Fields Within Regions of West Siberian Basin by Latitude and Longitude.

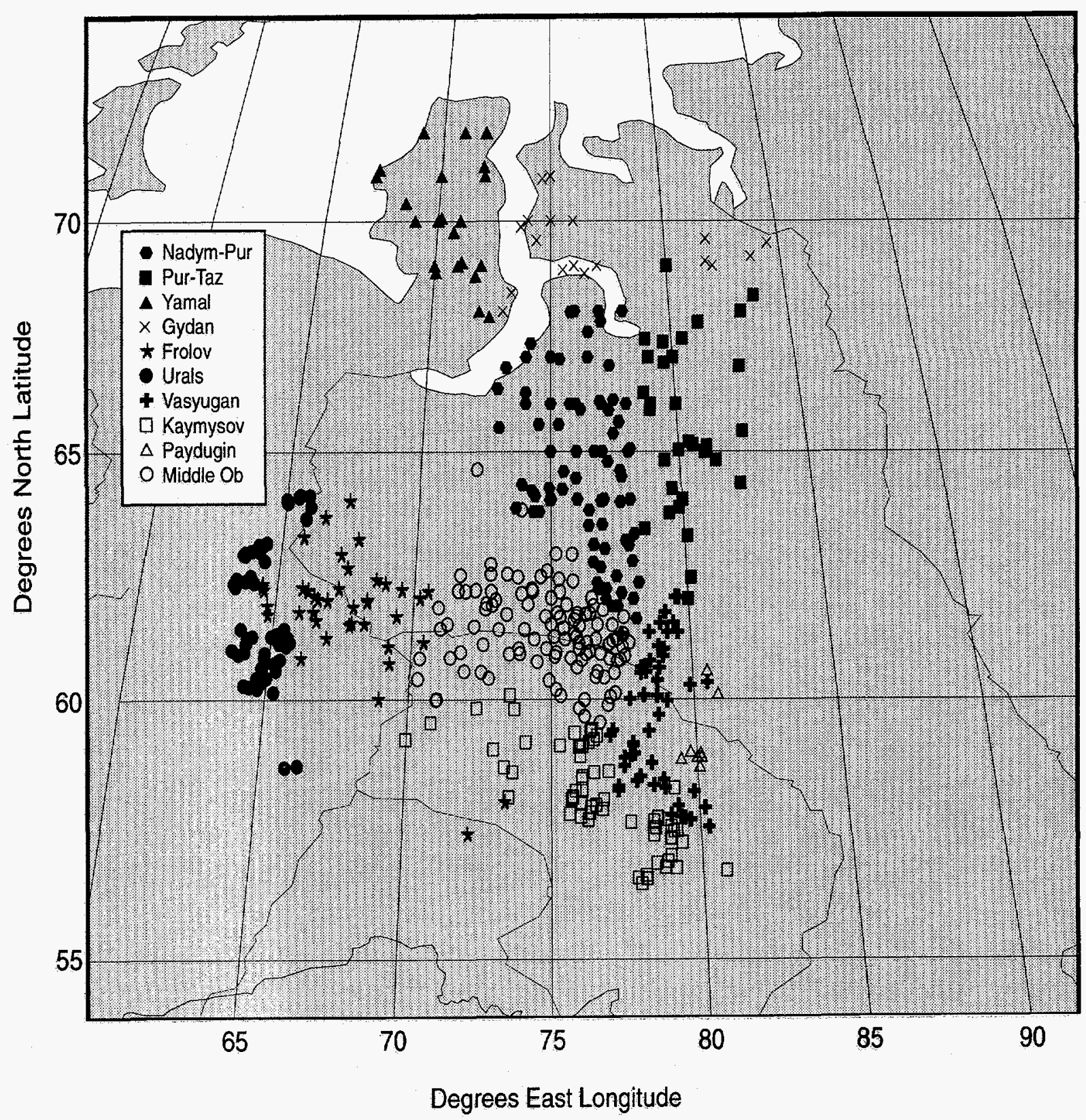

Source: Energy Information Administration, Office of Oil and Gas. 
Figure 2B. Location of Fields PIoducing from the Upper Cretaceous (All Areas) West Siberian Basin.

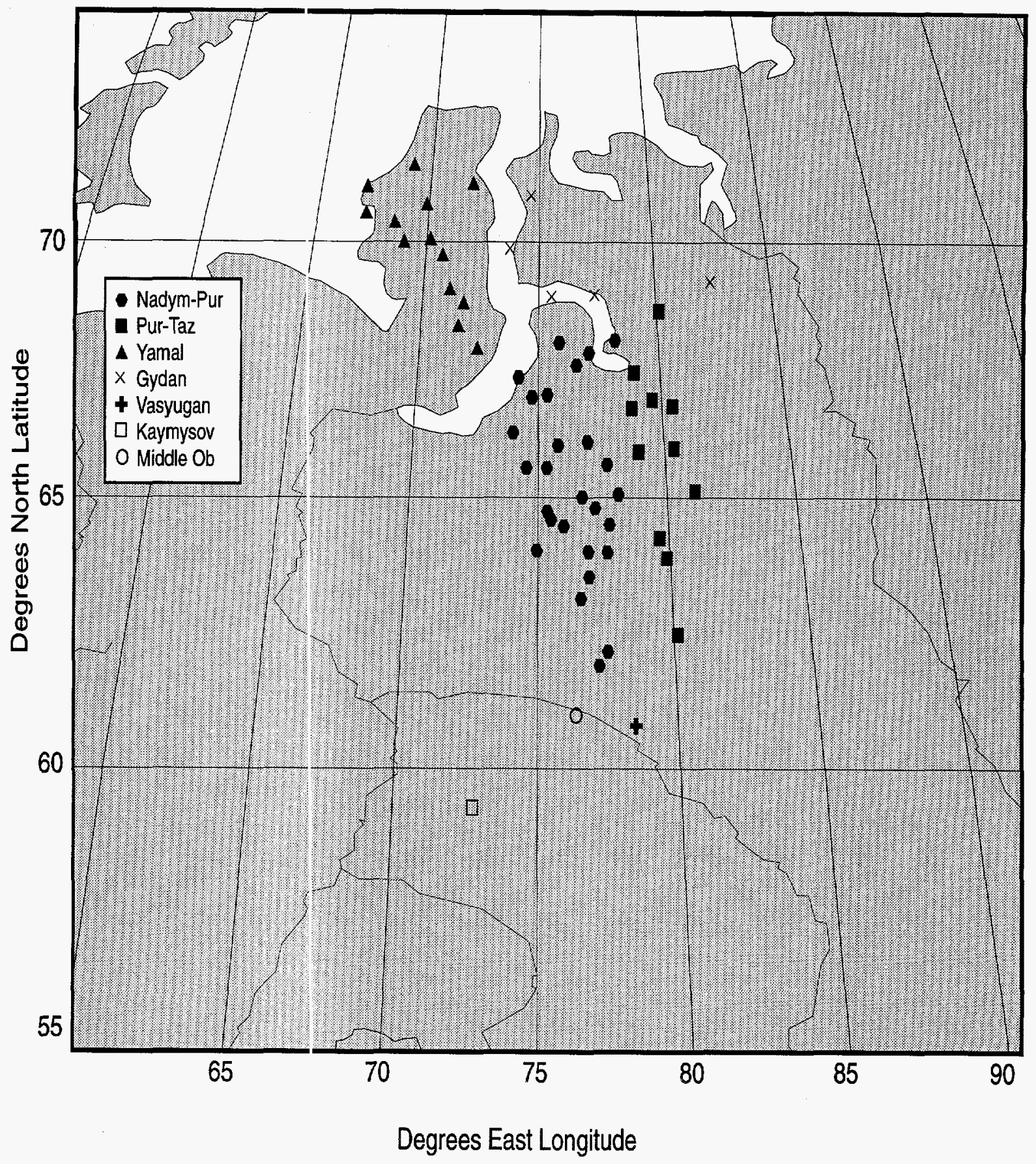

Source: Energy Information Administration, Office of Oil and Gas. 
Figure 3B. Location of Fields Producing from the North Albian - Aptian Interval (North Area) West Siberian Basin.

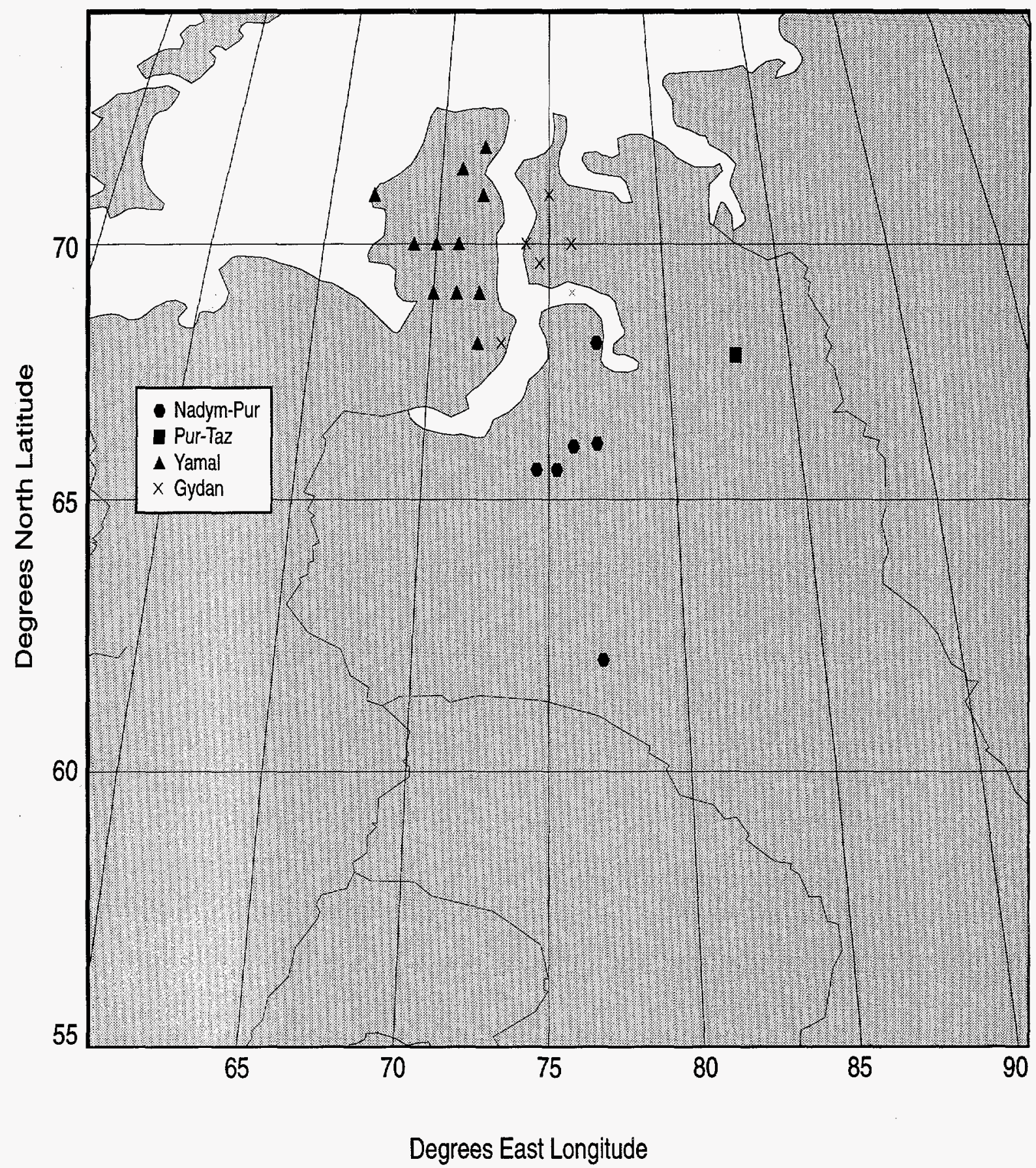

Source: Energy Information Administration, Office of Oil and Gas 
Figure 4B. Location of Fields Producing from the Albian-Aptian Interval (South Area) West Siberian Basin.

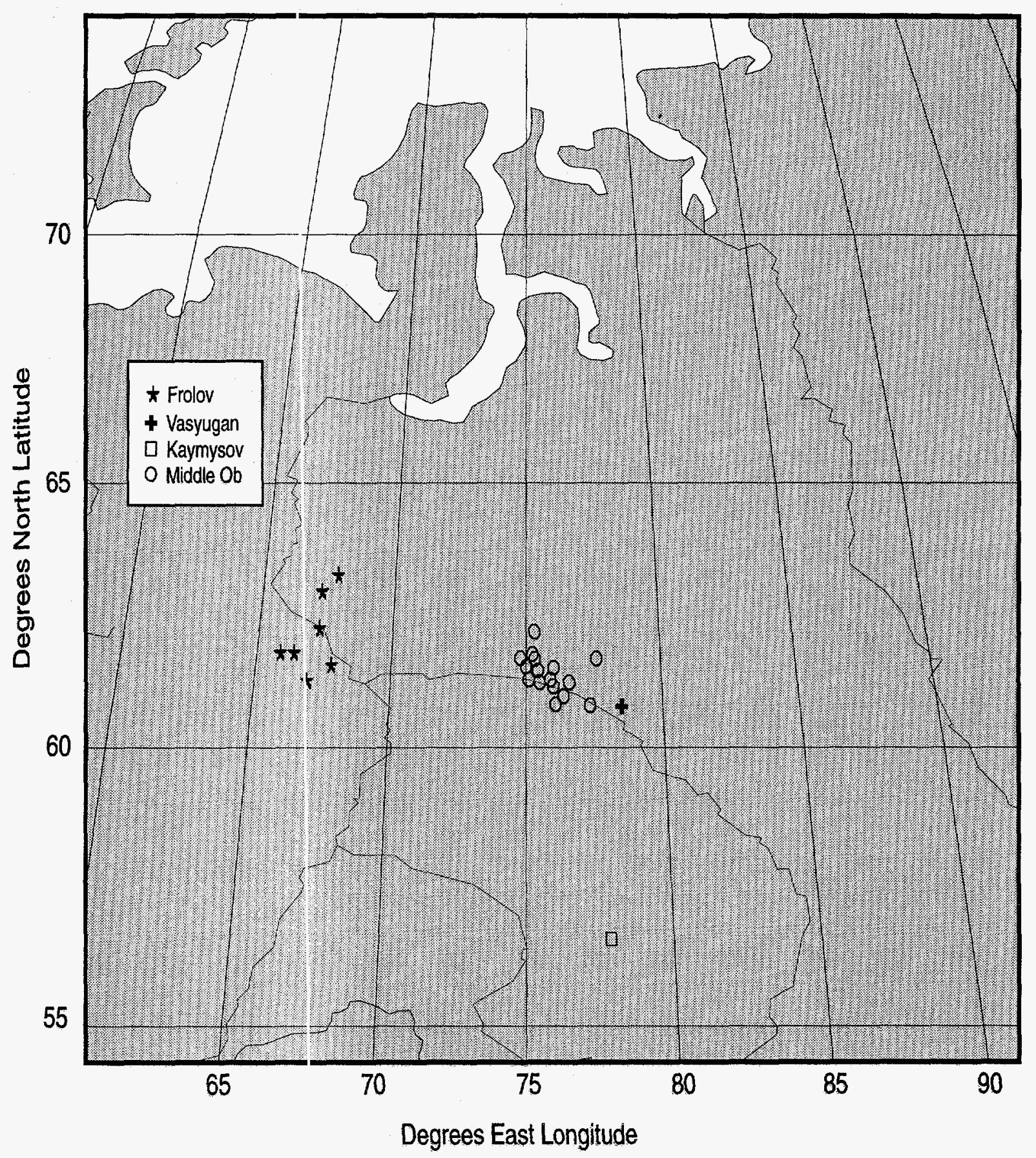

Source: Energy information Aulministration, Office of Oil and Gas. 
Figure 5B. Location of Fields Producing from the Neocomian Interval (North Area) West Siberian Basin.

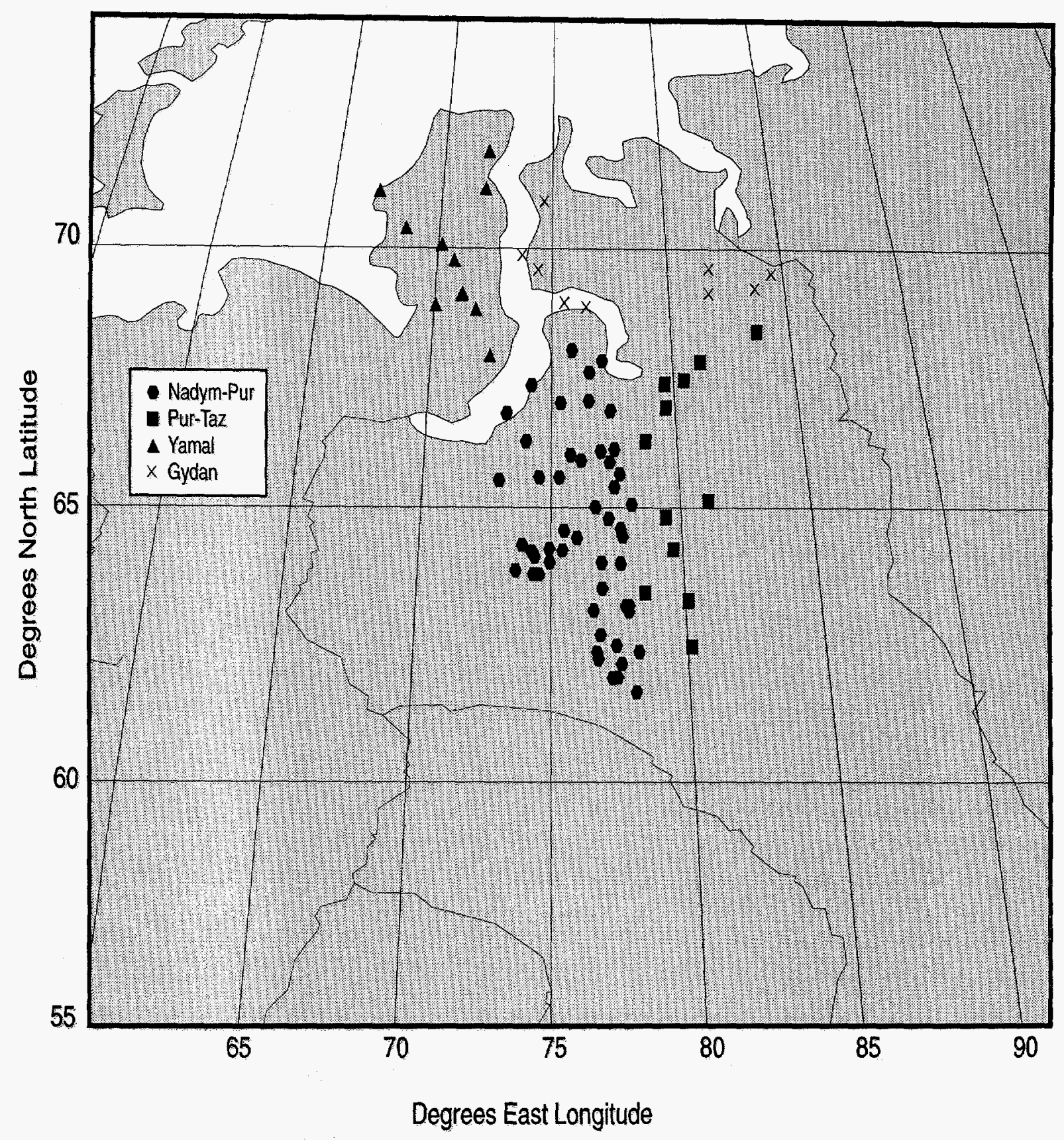

Source: Energy mformation Administration, Office of Oil and Gas. 
Figure 6B. Location of Fields Producing from the Neocomian Interval (South Area) West Siberian Basin.

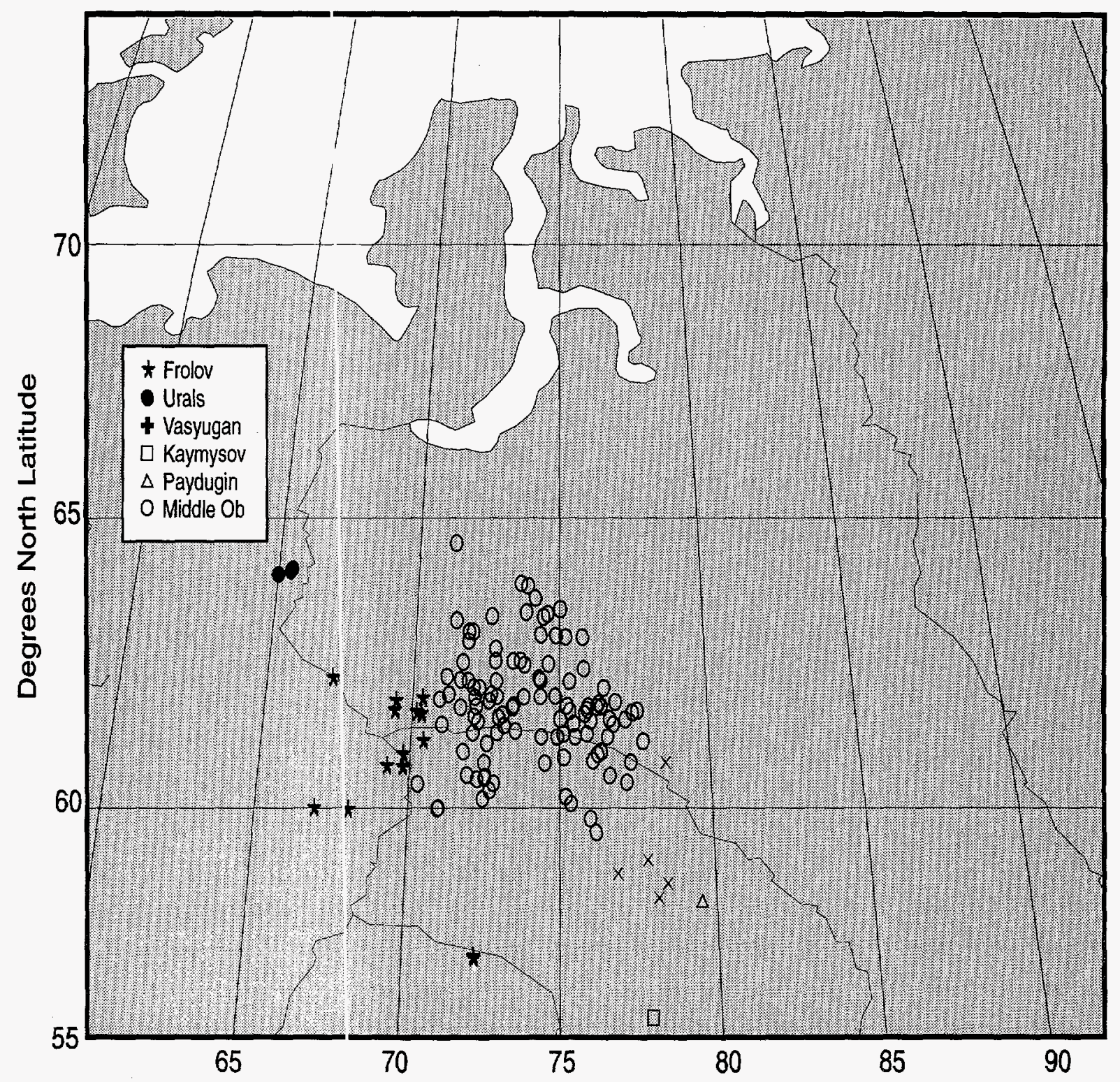

Degrees East Longitude

Source: Energy Information Administratior, Office of Oil and Gas 
Figure 7B. Location of Fields Producing from the Jurassic Interval (North Area) West Siberian Basin.

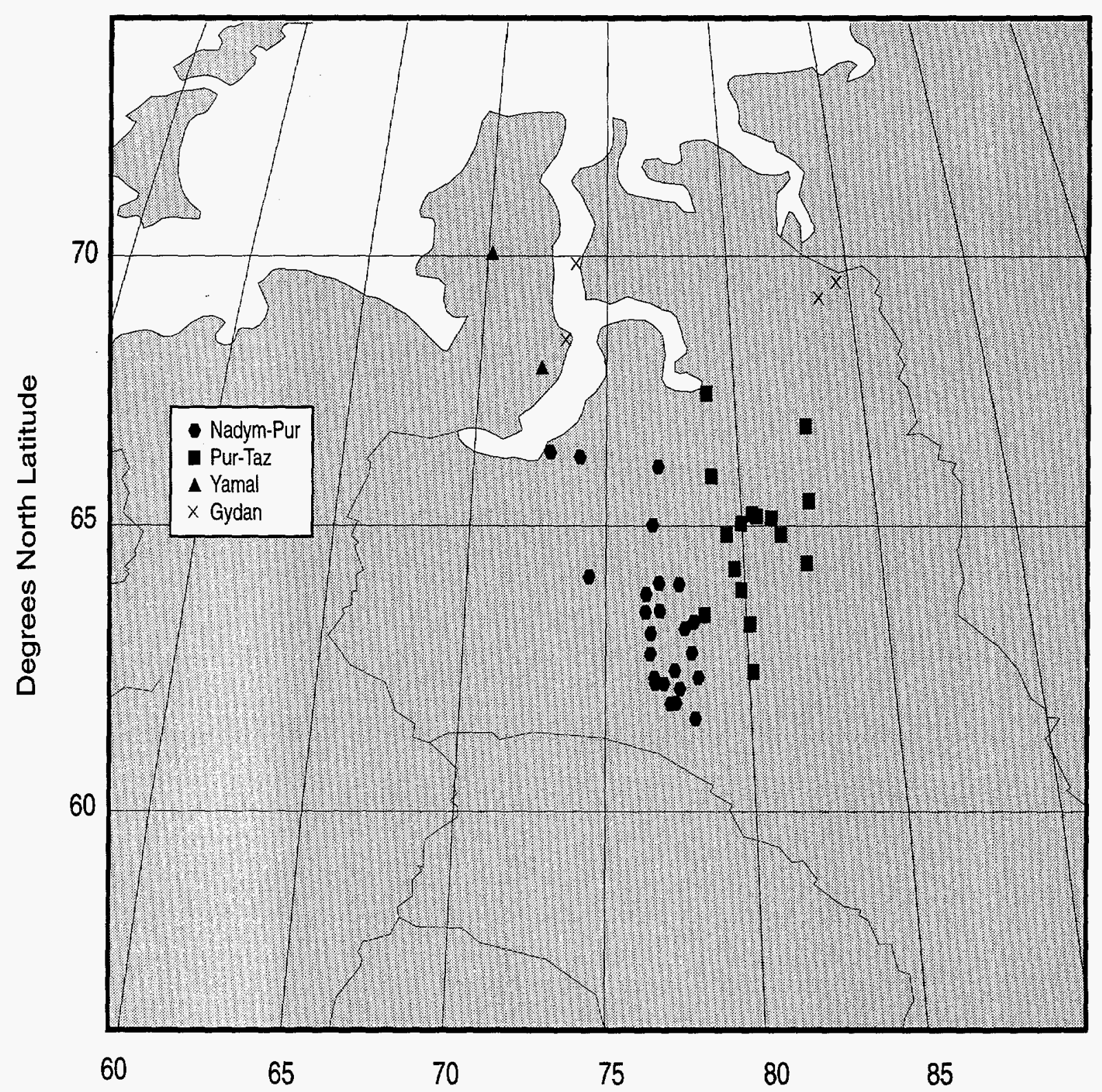

Degrees East Longitude

Source: Energy Information Administration, Office of Oil and Gas. 
Figure 8B. Location of Fields Producing from the Jurassic Interval (South Area) West Siberian Basin.

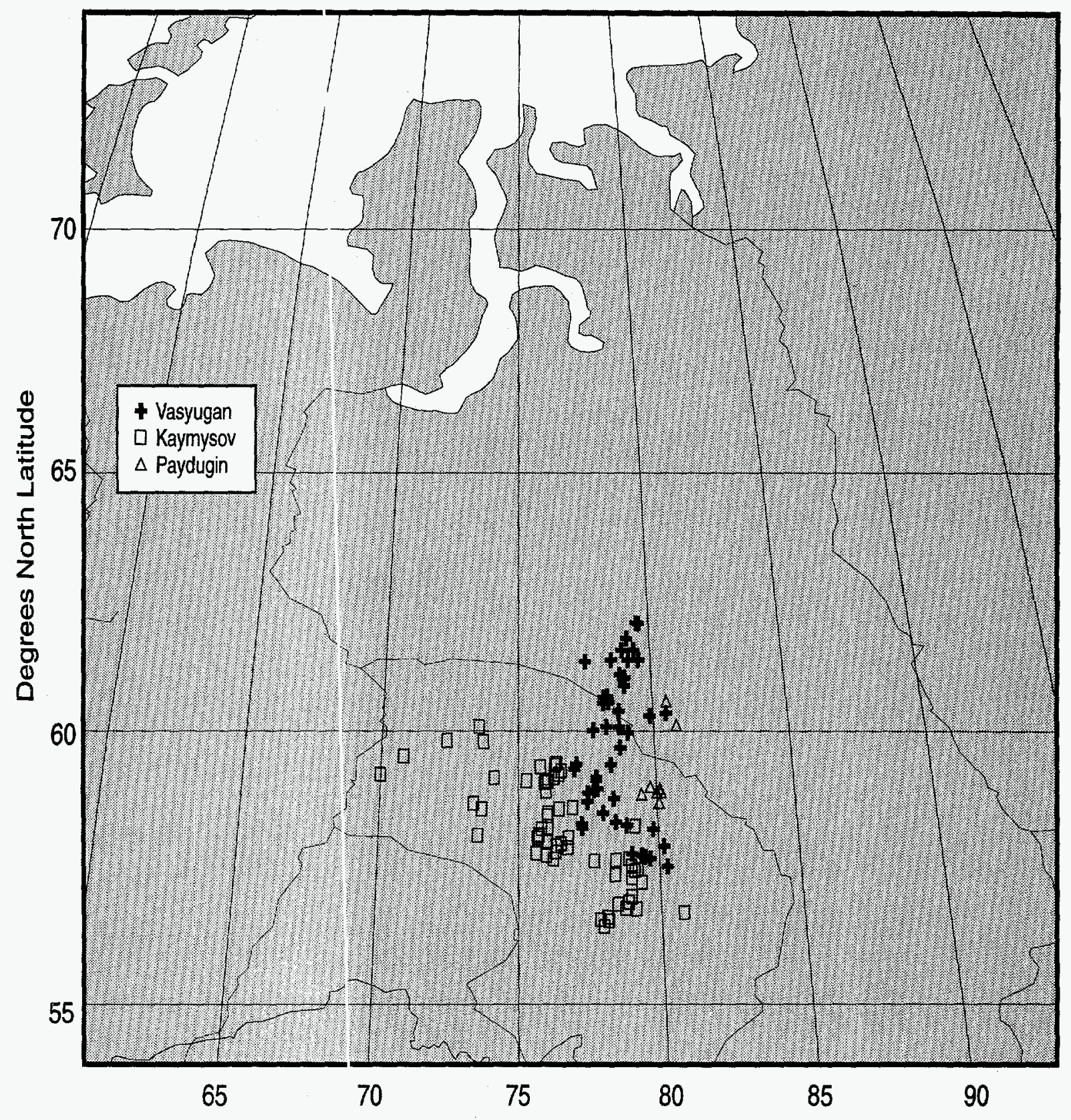

Degrees East Longitude

Source: Energy information Administration, Office of Oil and Gas. 
Figure 9B. Location of Fields Producing from the Jurassic Interval (West Area) West Siberian Basin.

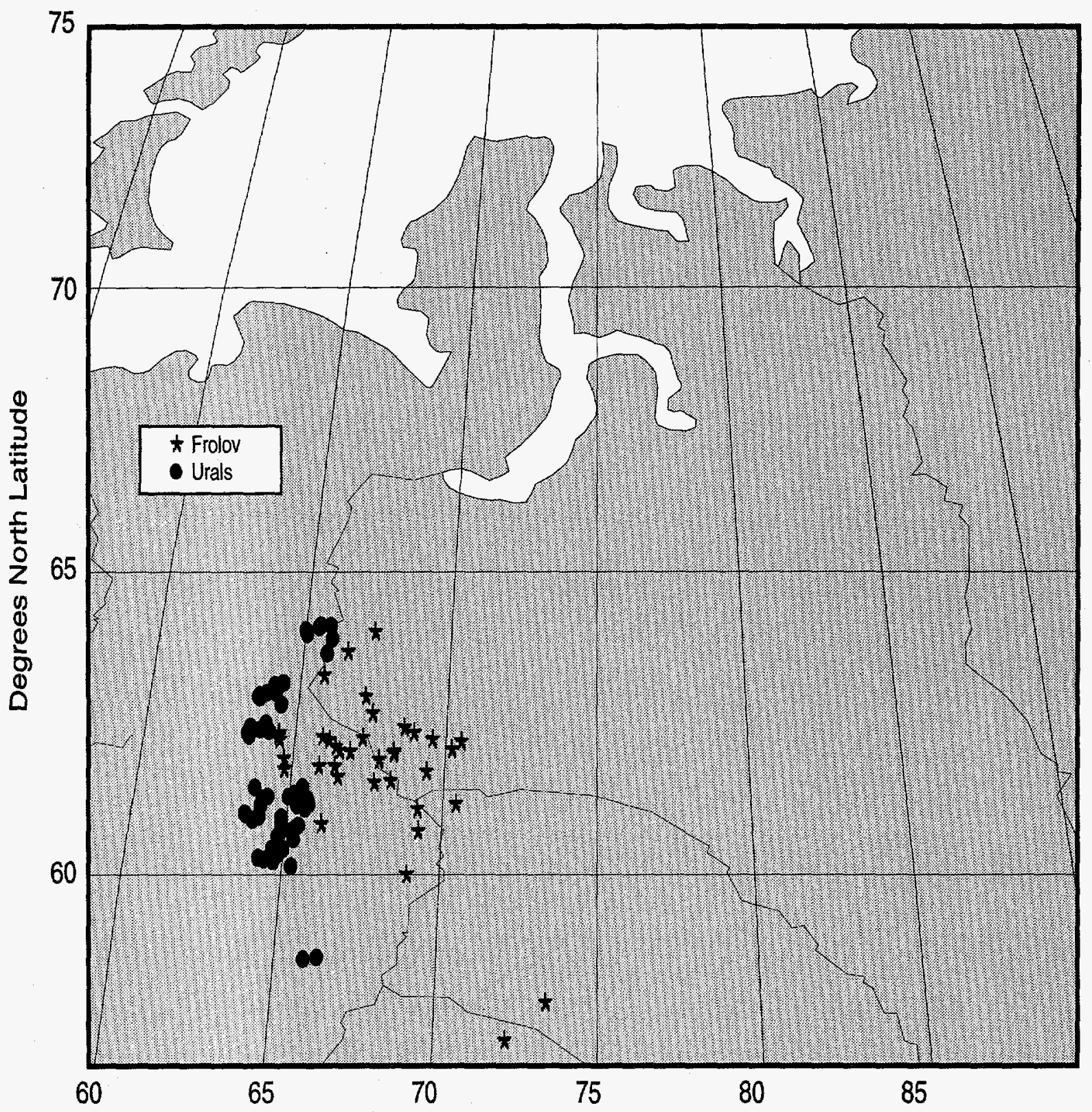

Degrees East Longitude

Source: Energy Information Administration, Office of Oil and Gas. 
Figure 10B. Location of Fields I'roducing from the Jurassic Interval (Middle Ob Region) West Siberian Basirı.

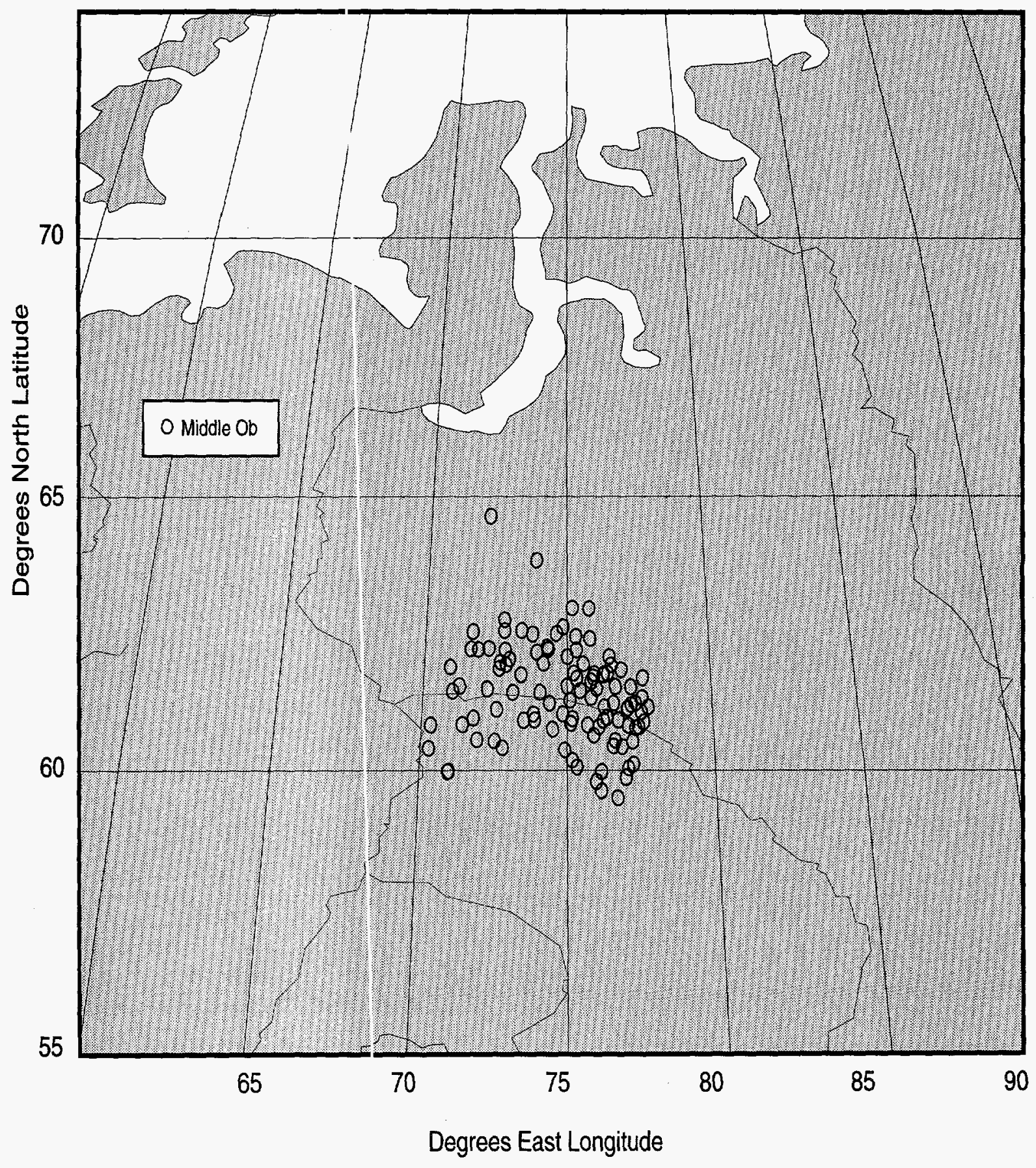

Source: Energy Information Administration, Office of Oil and Gas. 
Figure 11B. Location of Fields Producing from the Triassic-Paleozoic Interval (All Areas) West Siberian Basin.

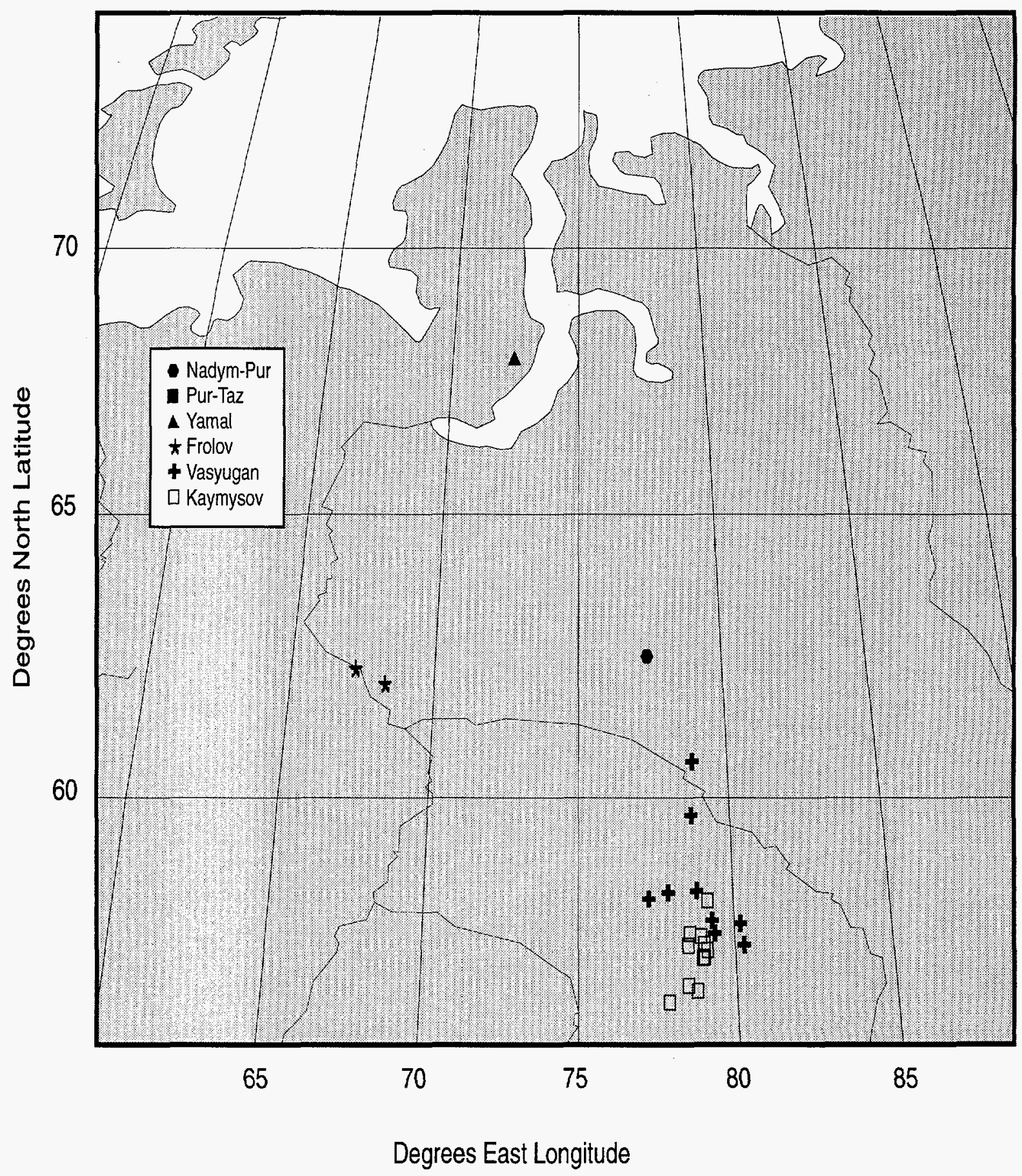

Source: Energy Information Administration, Office of Oil and Gas. 
Figure 12B. Measured Bottom Hole Pressure (BHP) at Peported Depth, West Siberian Basin

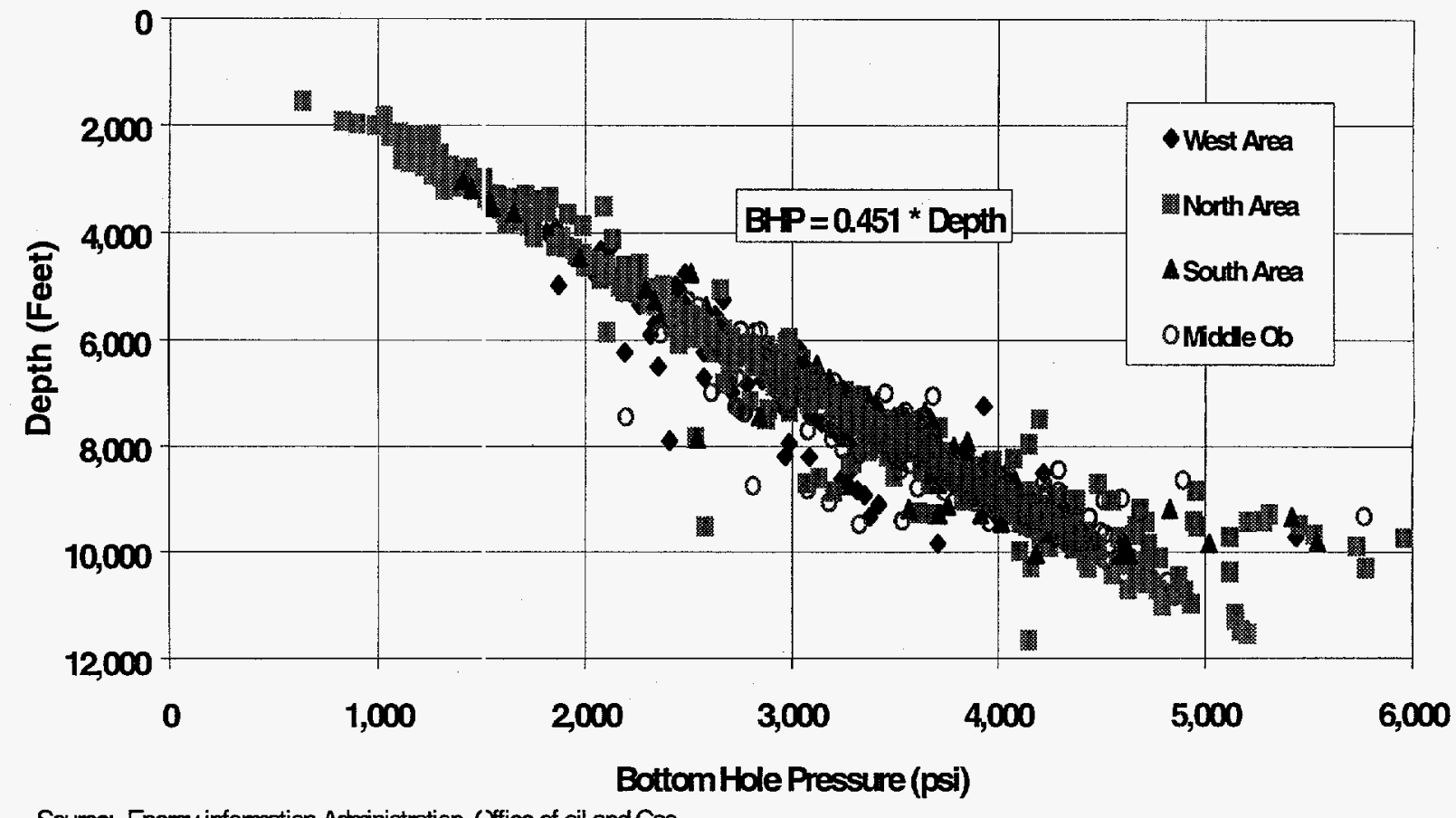

Source: Energy information Administration, (ffice of oil and Gas.

Figure 13B. Measured Bottom Hole Temperature (BHT) at Reported Depth, West Siberian Basin.

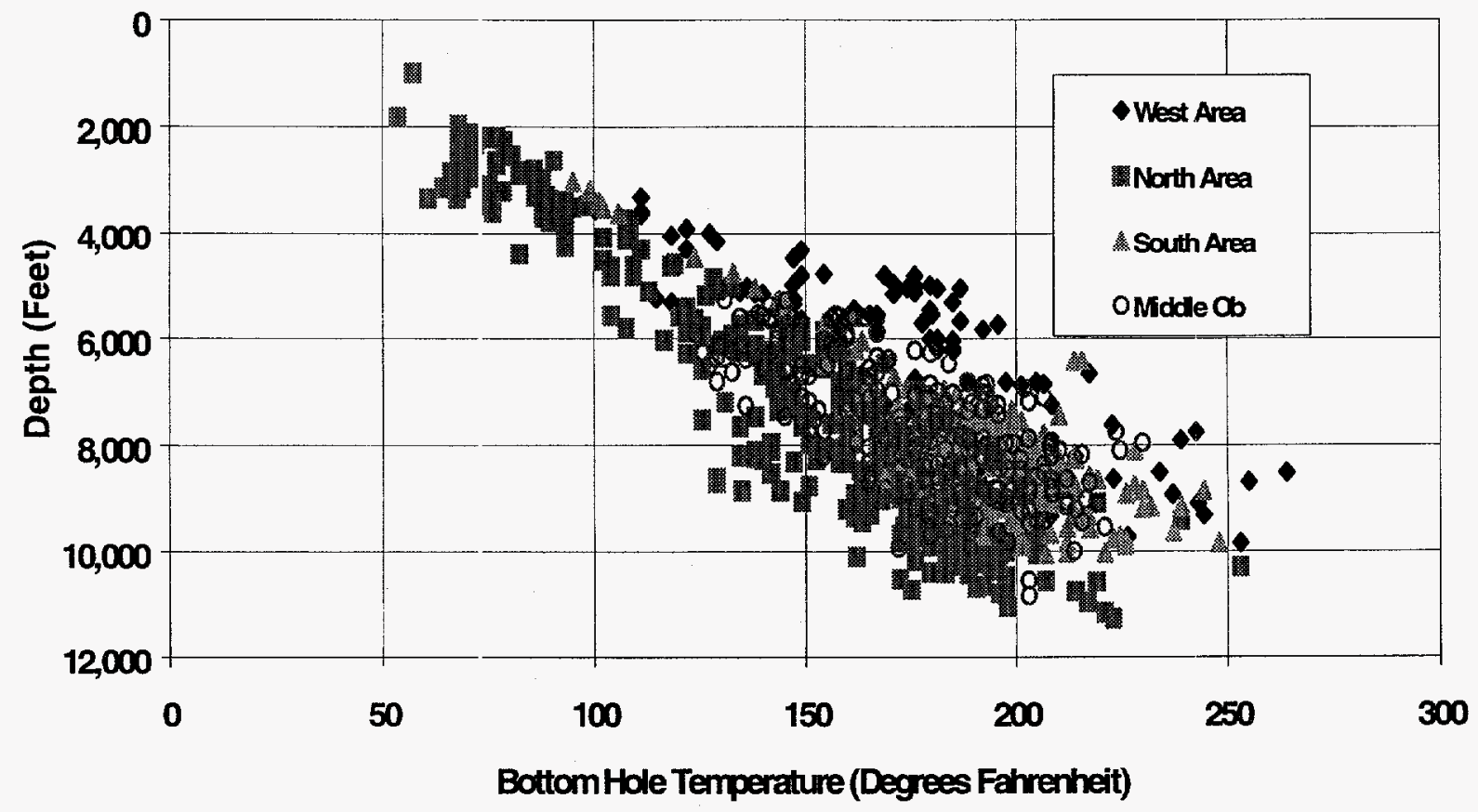

Source: Energy Information Administration Office of Cil and Ges. 
Figure 14B. Bottom Hole Temperature (BHT) at Depth for the North Area, West Siberian Basin.

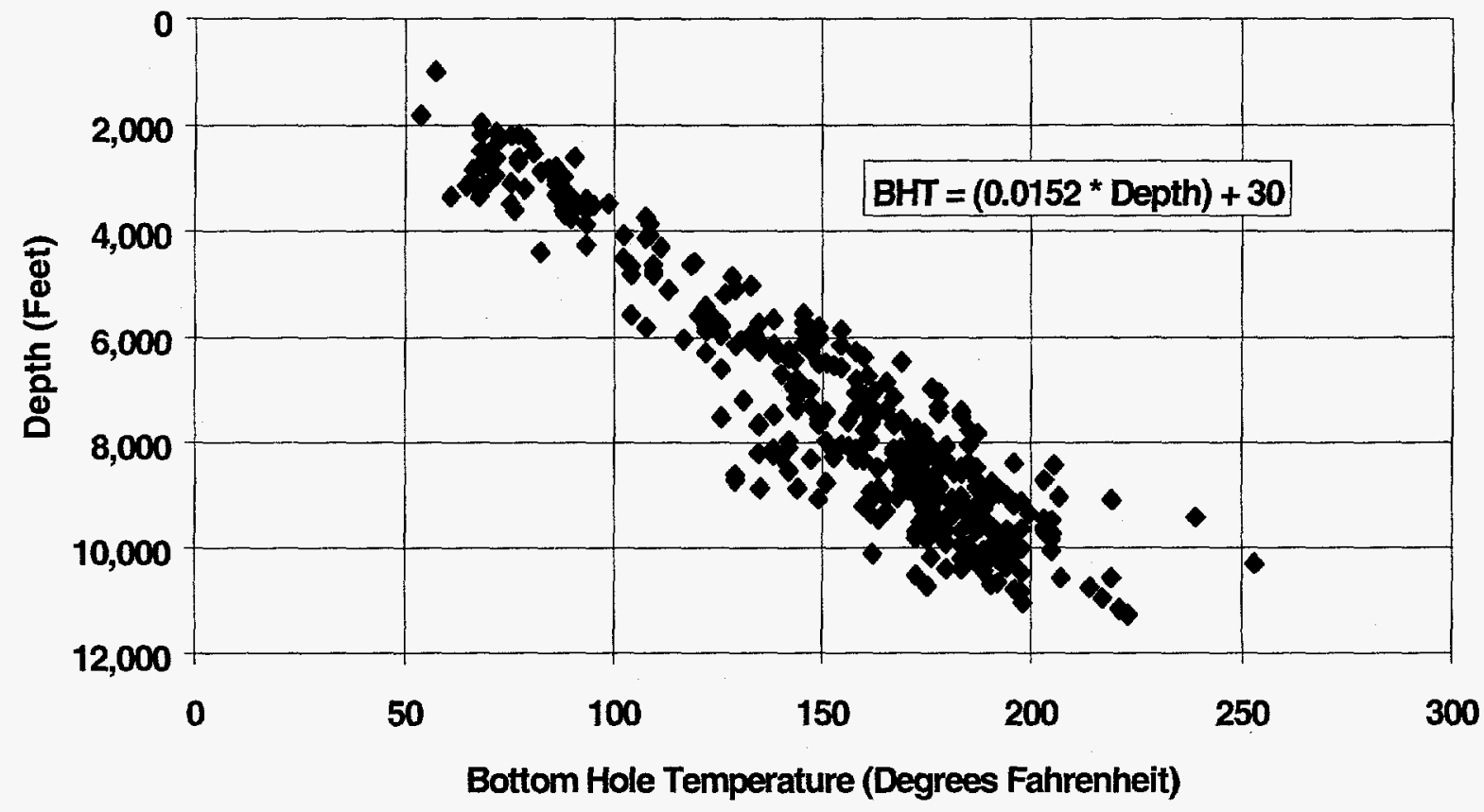

Source: Energy Information Administration, Office of Oil and Gas.

Figure 15B. Bottom Hole Temperature (BHT) at Depth for the South Area, West Siberian Basin.

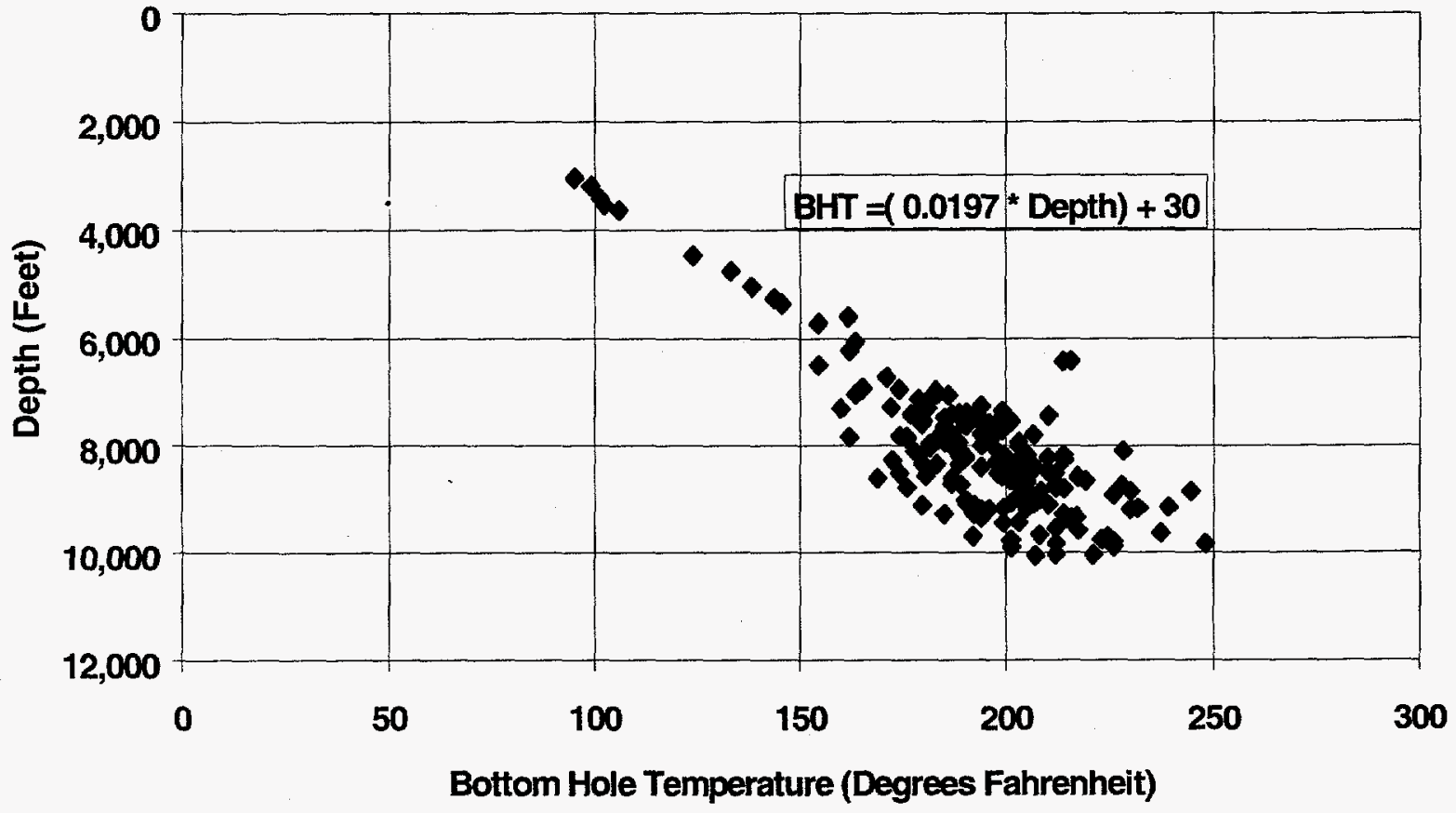

Source: Energy Information Administration, Office of Oil and Gas. 
Figure 16B. Bottom Hole Temfrerature (BHT) at Depth for the West Area, West Siberian Basin.

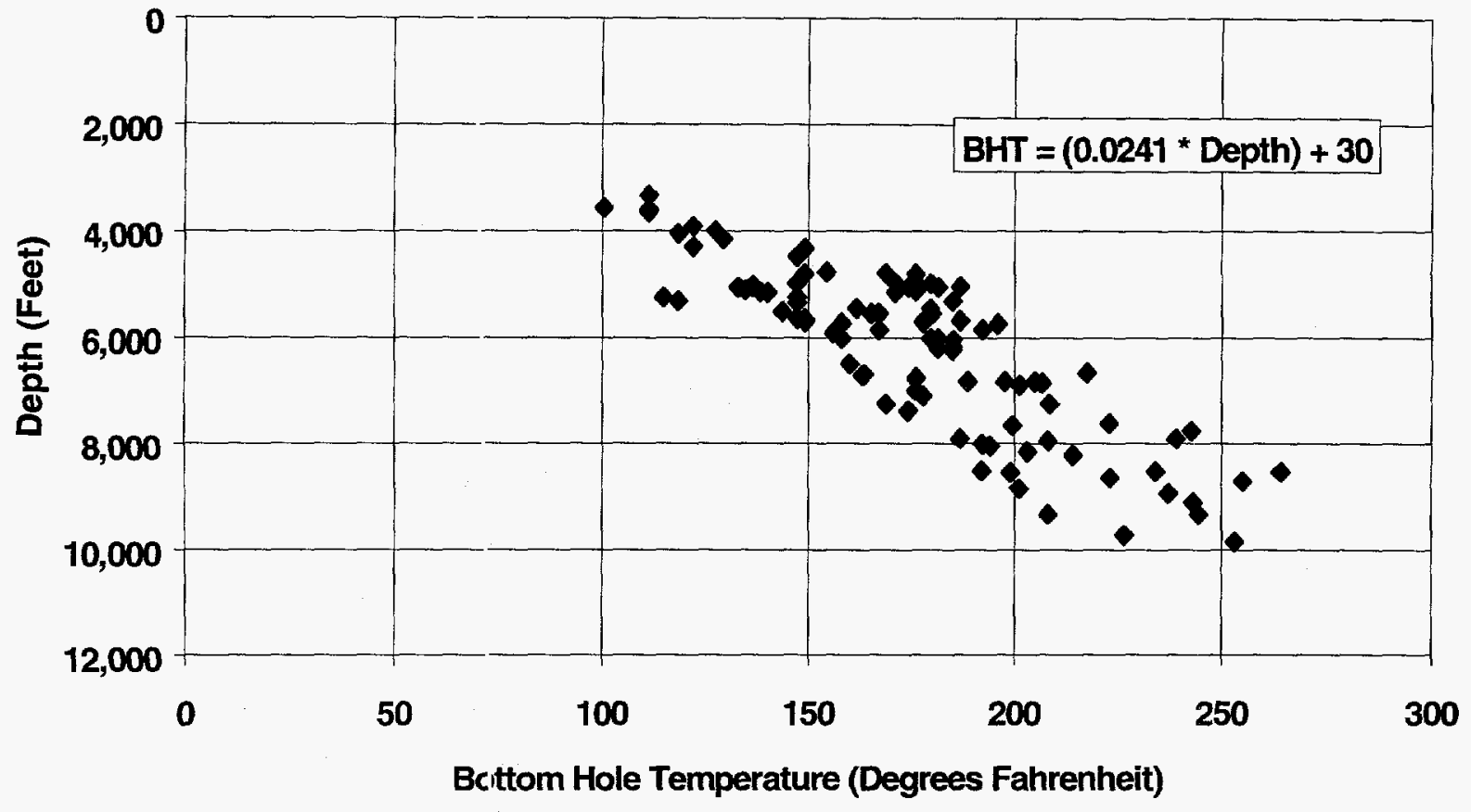

Source: Energy Information Administra:ion, Office of Oil and Gas

Figure 17B. Bottom Hole Temperature (BHT) at Depth for the Middle Ob Area, West Siberian Basin.

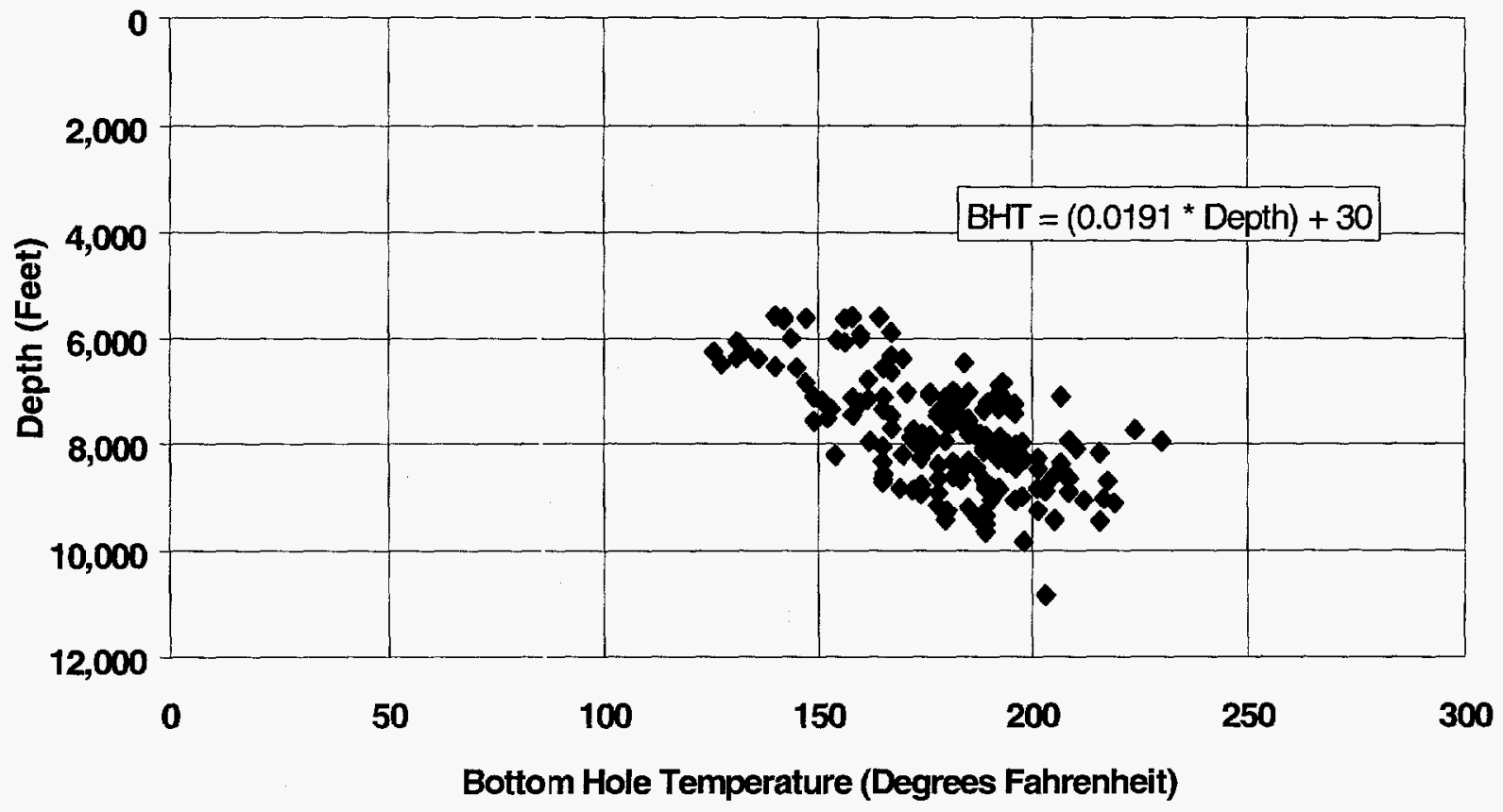

Source: Energy Information Administration, Office of Oil and Gas. 
Figure 18B. Distribution of Reservoir Parameters in the Upper Cretaceous Interval (All Areas), West Siberian Basin.
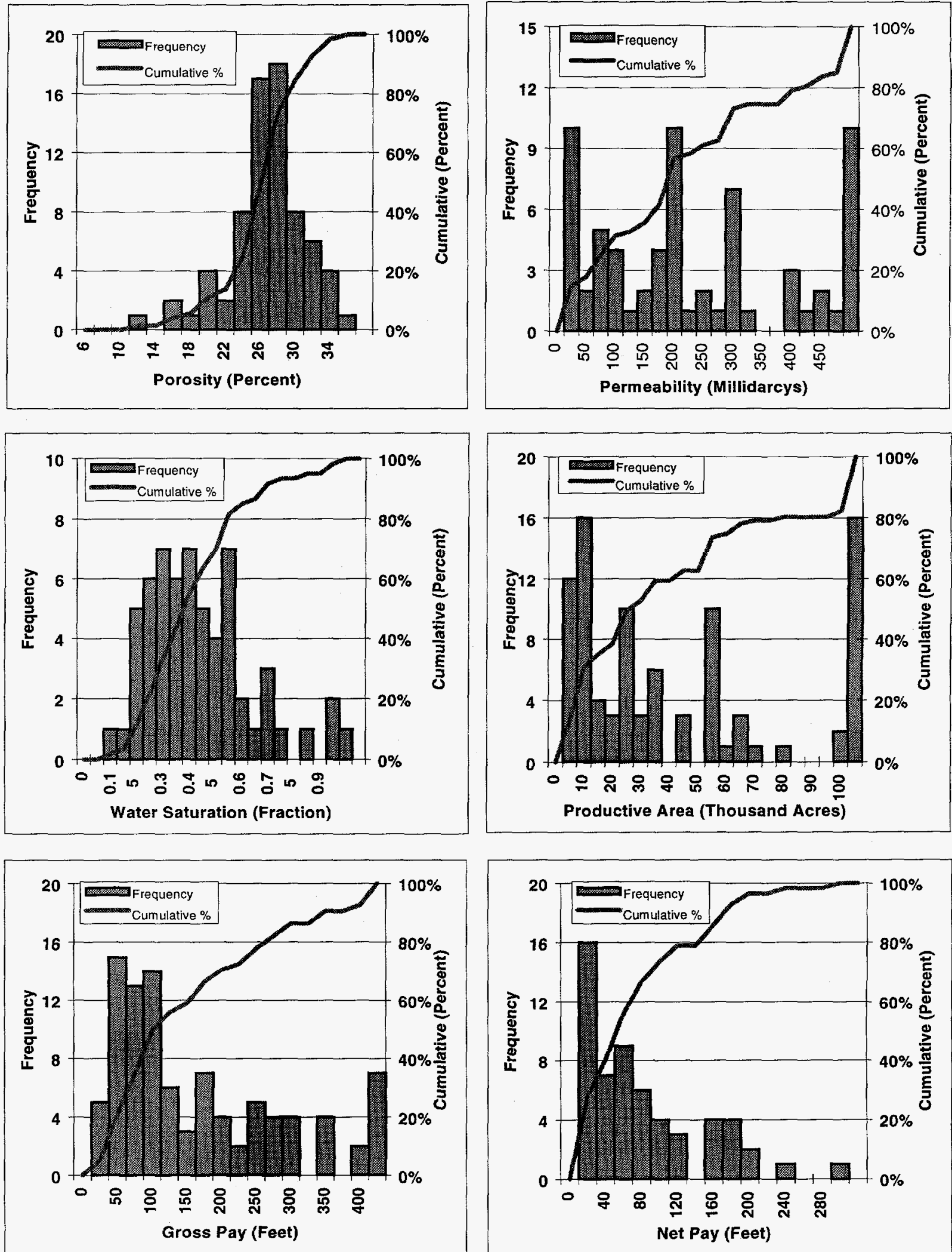

Source: Energy Information Administration, Office of Oil and Gas. 
Figure 19B. Distribution of Reservoir Parameters in the Albian-Aptian Interval (North Area), West Siberian Basir.
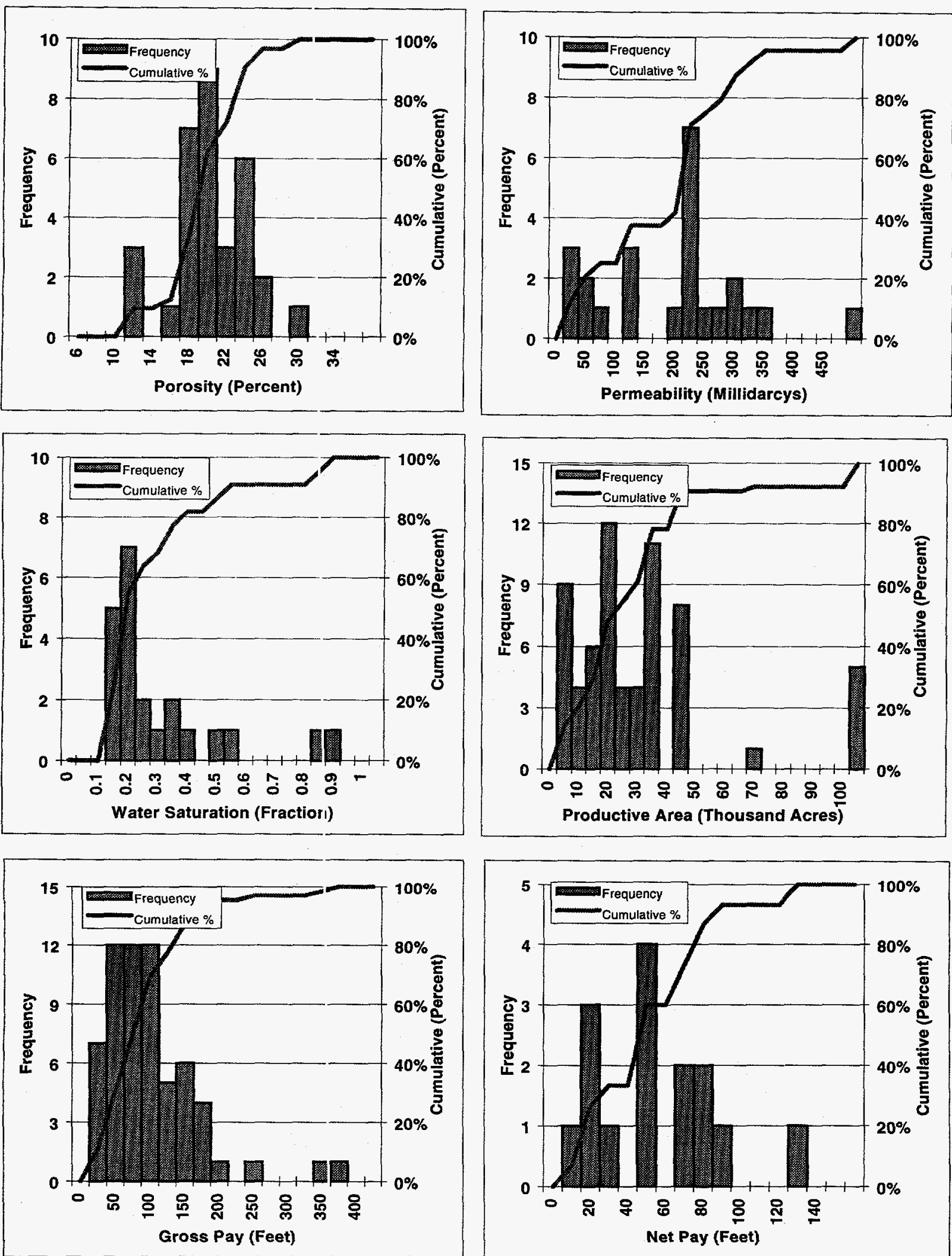

Source: Energy Information Administration, Office of oll and Gas. 
Figure 20B. Distribution of Reservoir Parameters in the Albian-Aptian Interval (South Area), West Siberian Basin.
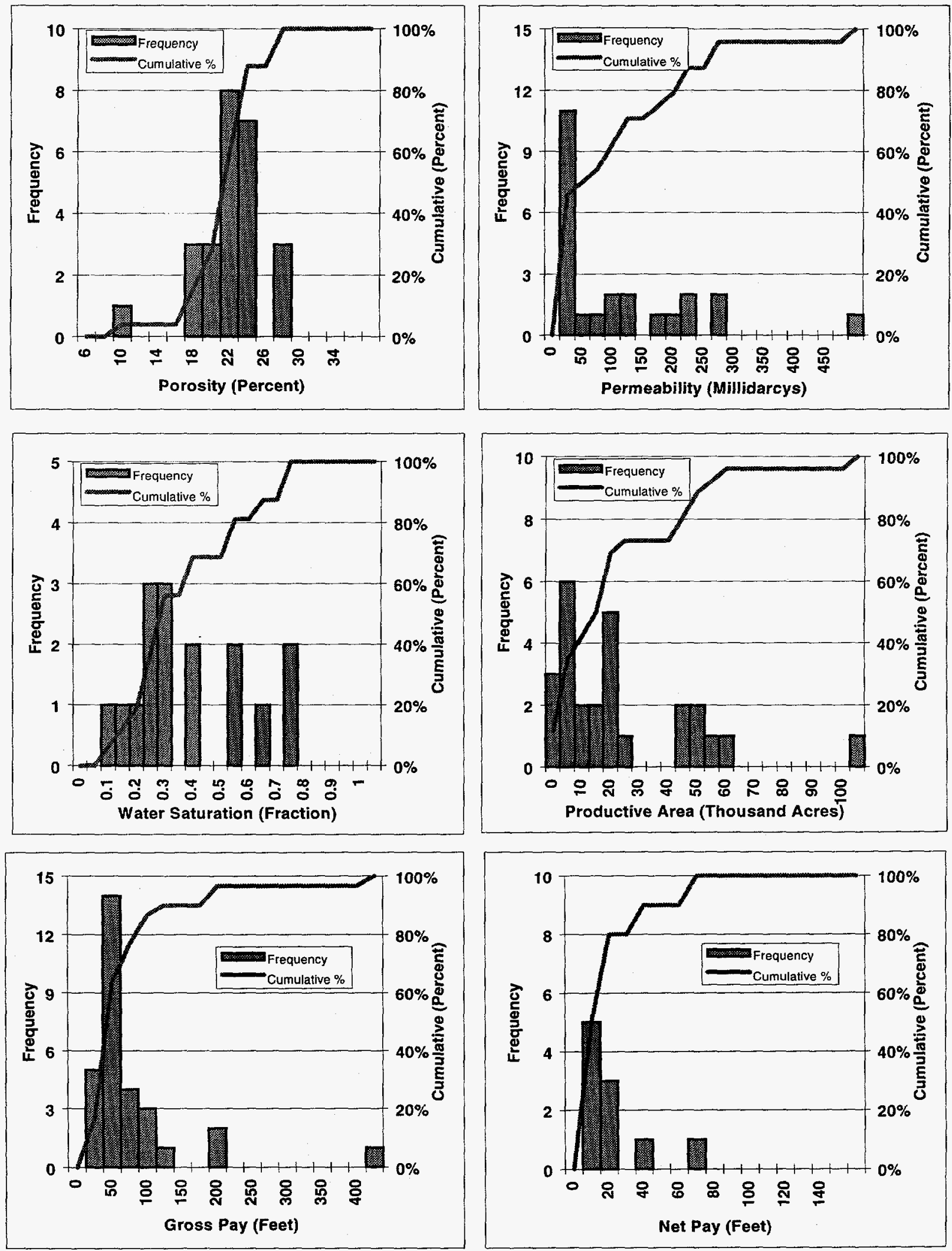

Source: Energy Information Administration, Office of oil and Gas. 
Figure 21B. Distribution of Restervoir Parameters in the Neocomian Interval (North Area), West Siberian Basin.
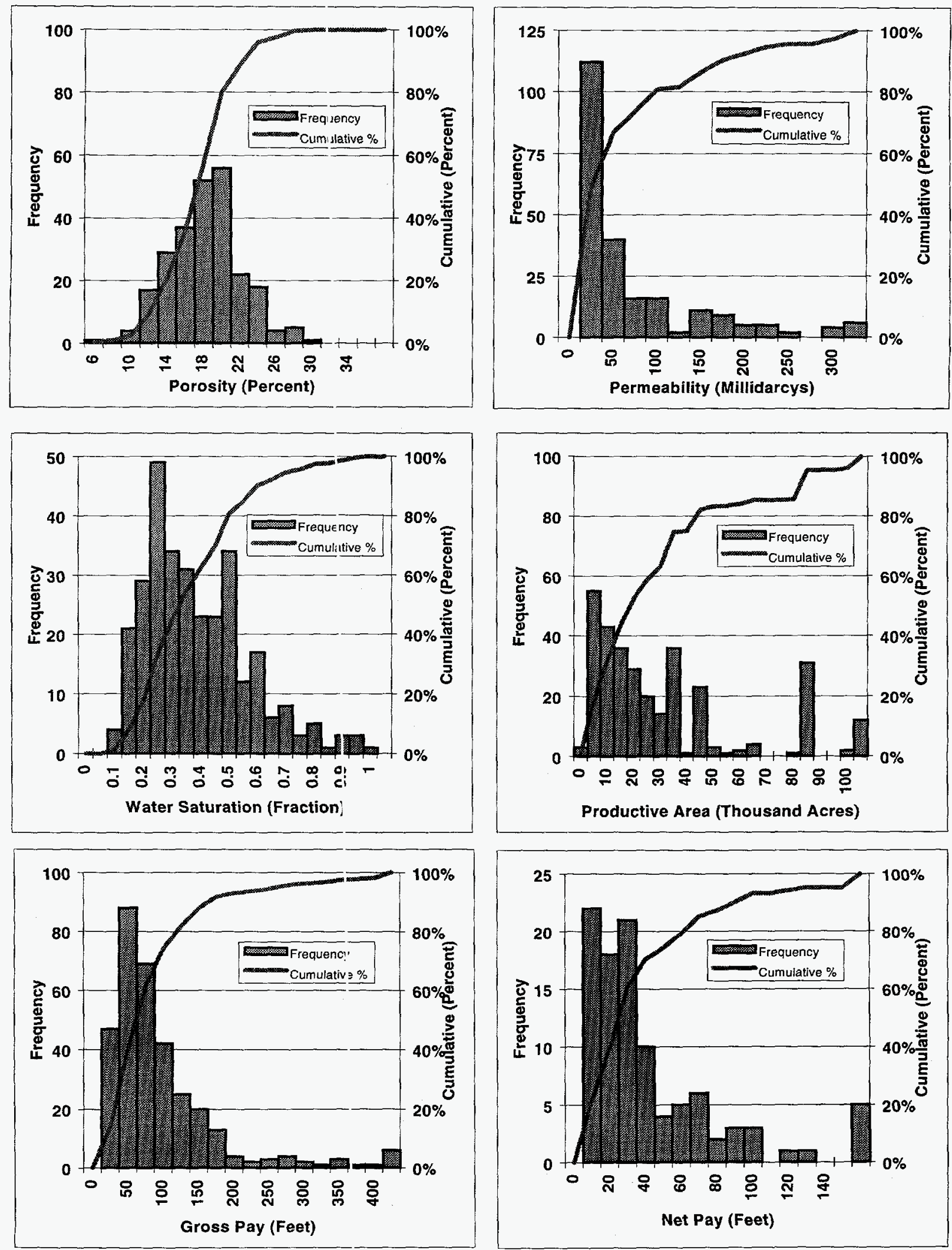

Source: Energy Information Administratior, Office of oil and Gas. 
Figure 22B. Distribution of Reservoir Parameters in the Neocomian Interval (South Area), West Siberian Basin.
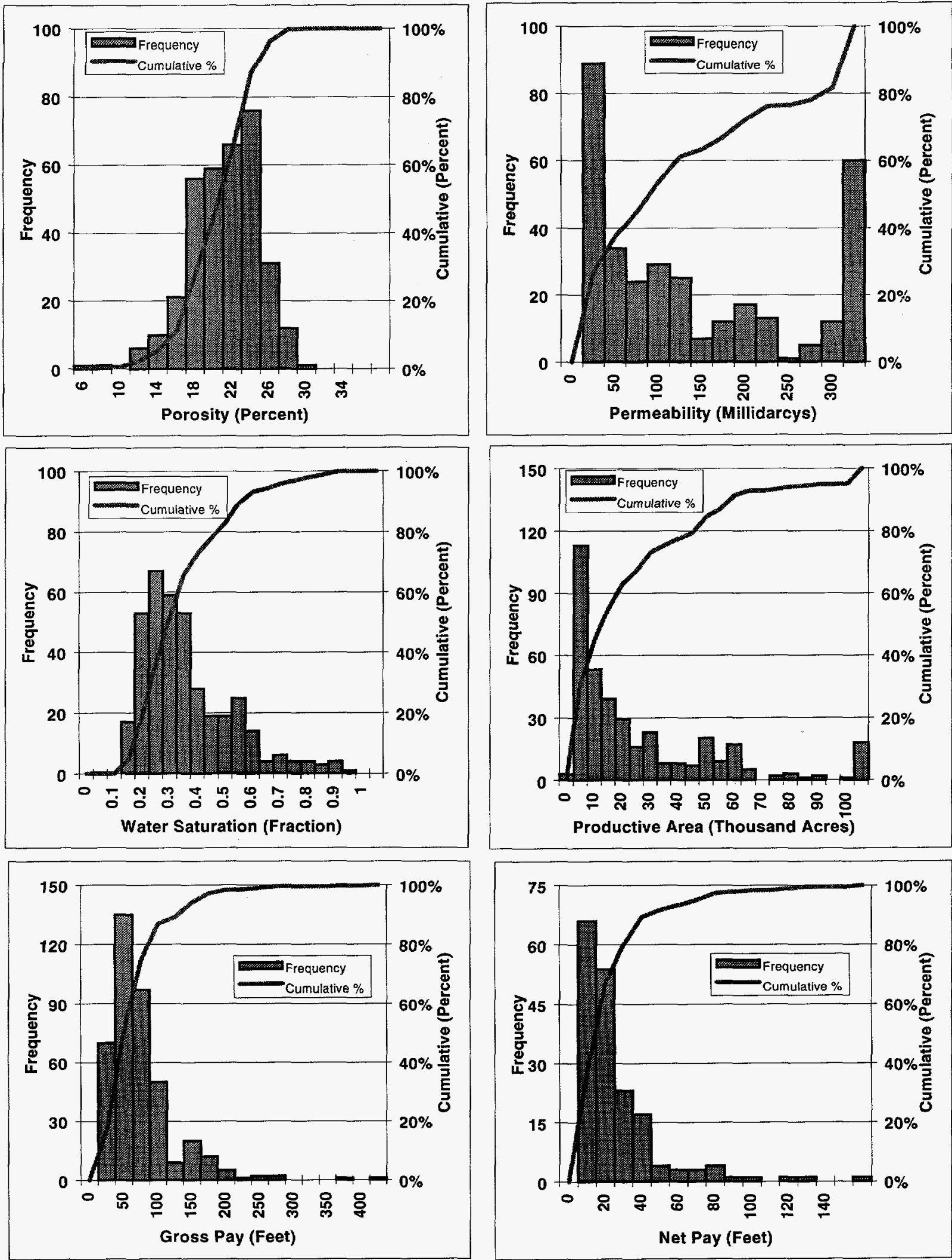

Source: Energy Information Administration, Office of oil and Gas. 
Figure 23B. Distribution of Reservoir Parameters in the Jurassic Interval (North Area), West Siberian Basin.
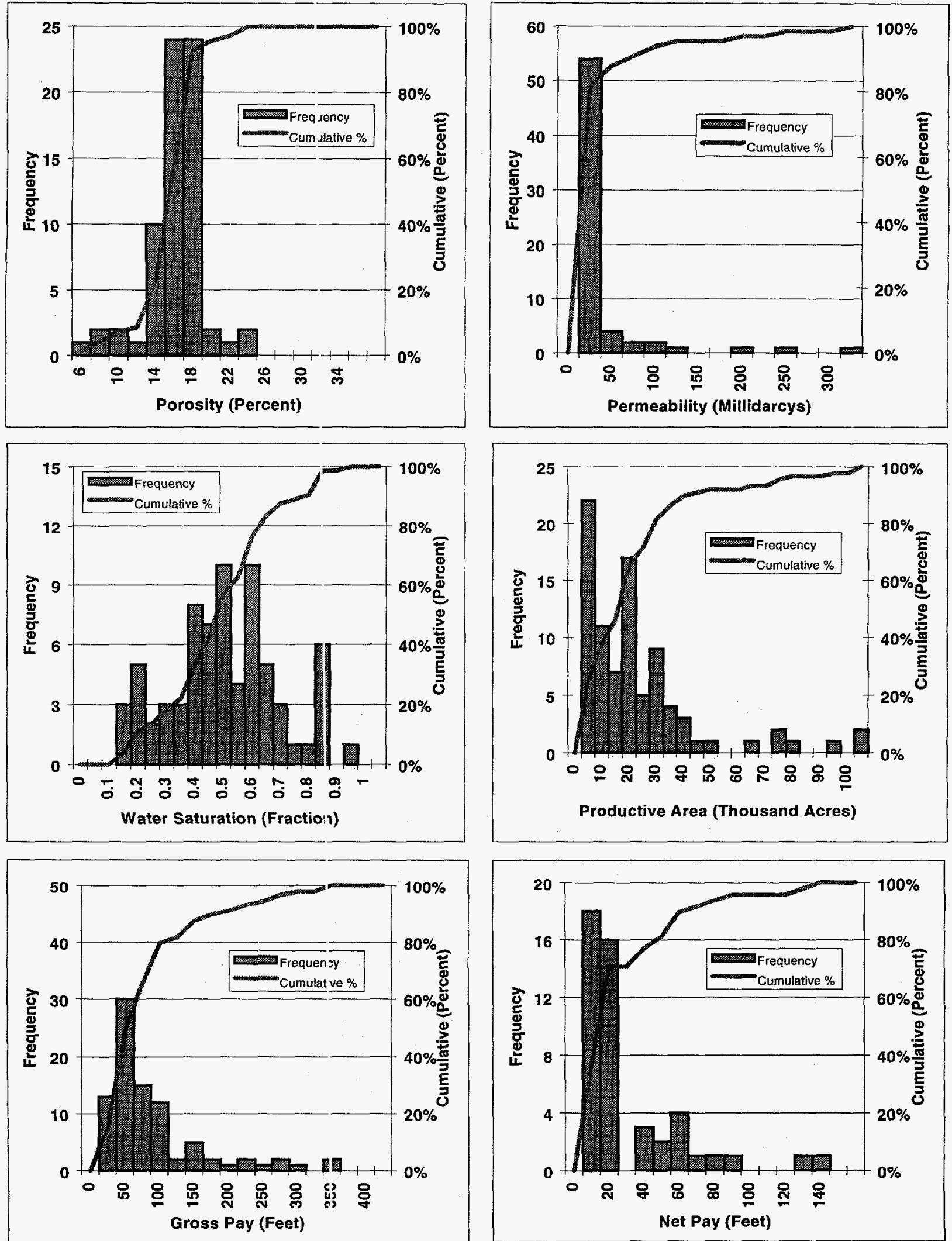

Source: Energy Information Administration, Office of oil and Gas. 
Figure 24B. Distribution of Reservoir Parameters in the Jurassic Interval (South Area), West Siberian Basin.
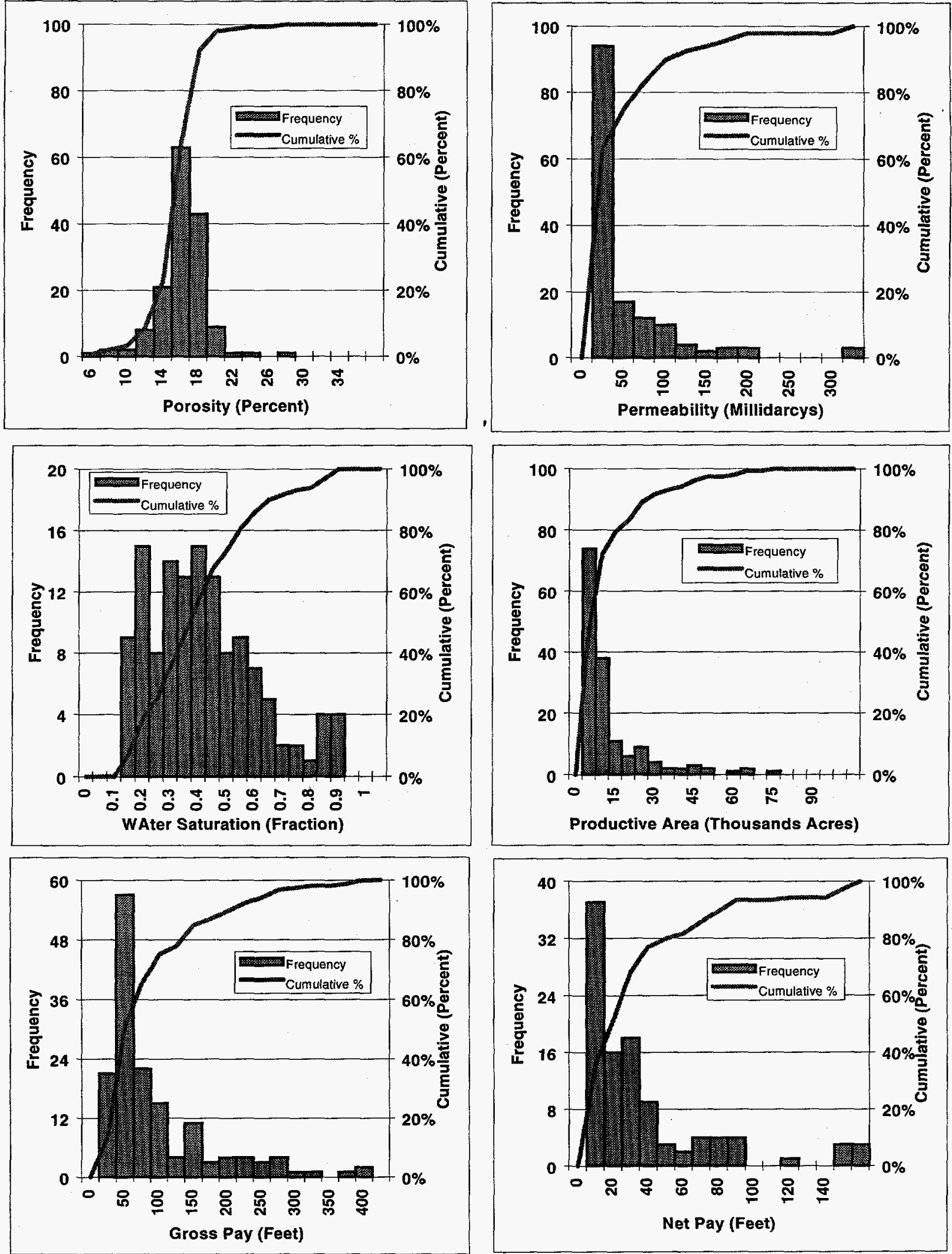

Source: Energy Information Administration, Office of oil and Gas. 
Figure 25B. Distribution of Resırvoir Parameters in the Jurassic Interval (West Area), West Siberian Basin.
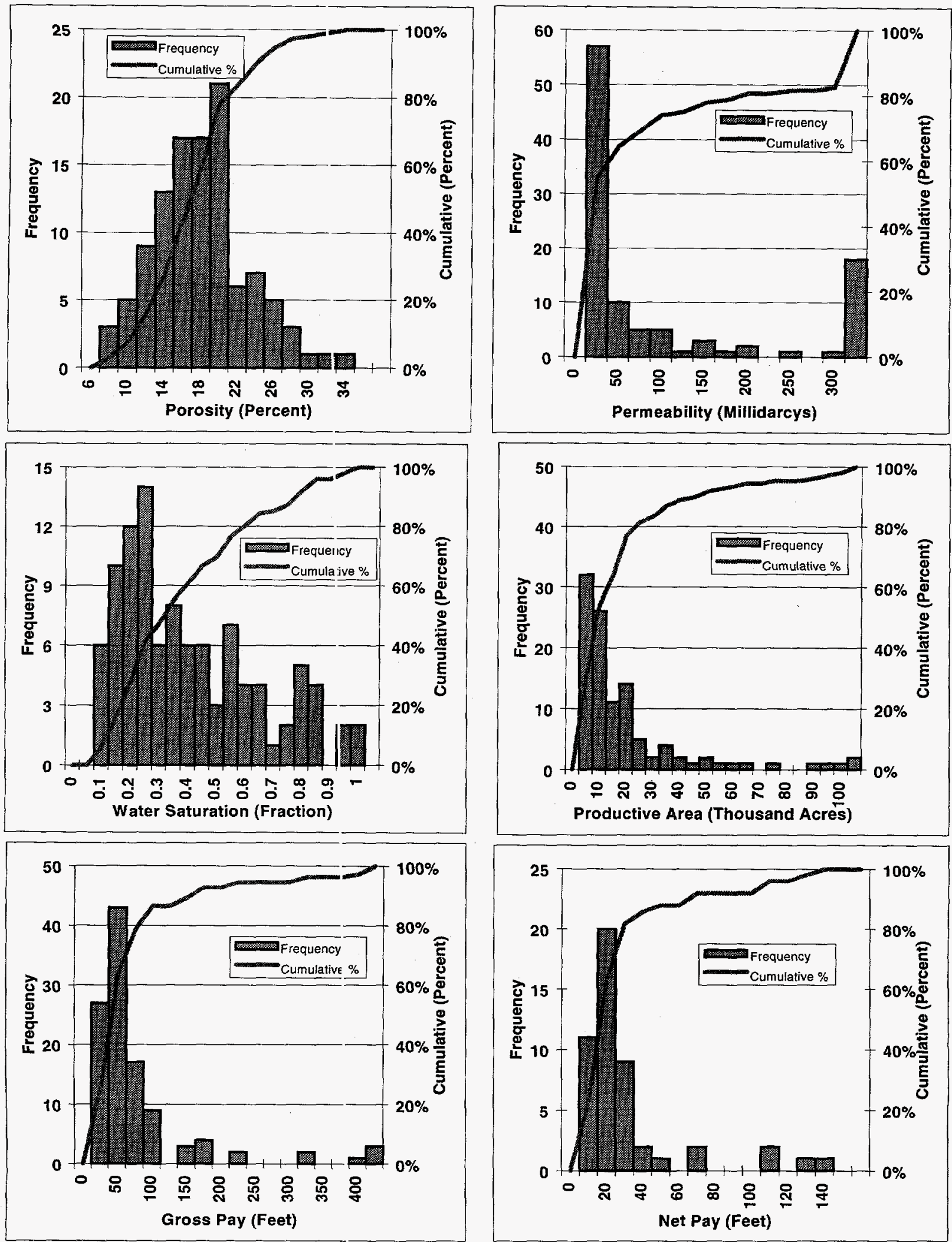

Source: Energy Information Administration, Office of oil and Gas. 
Figure 26B. Distribution of Reservoir Parameters in the Jurassic Interval (Middle Ob Area), West Siberian Basin.
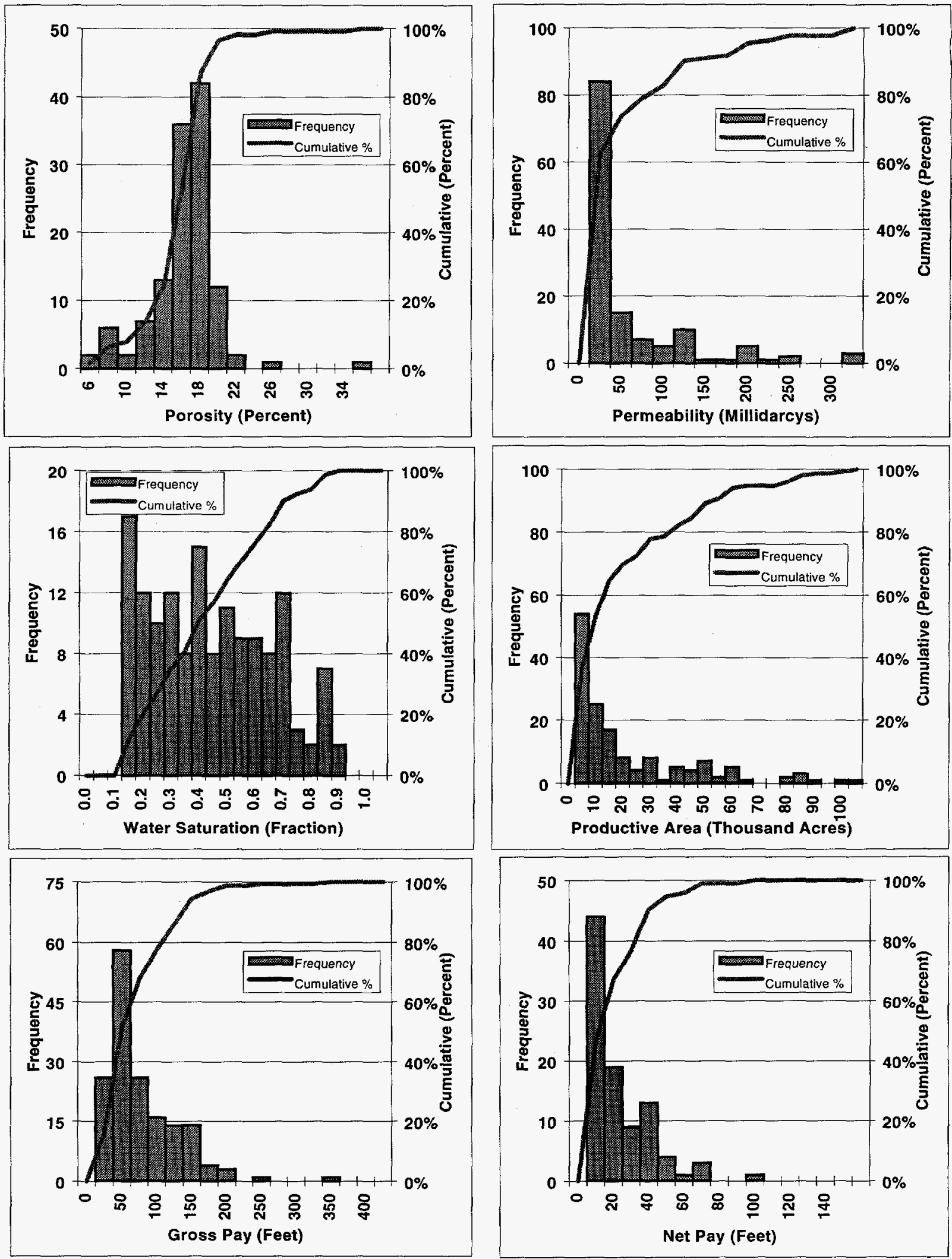

Source: Energy Information Administration, Office of oil and Gas. 
Figure 27B. Distribution of Res ervoir Parameters in the Triassic-Paleozoic Interval (All Areas), West Siljerian Basin.
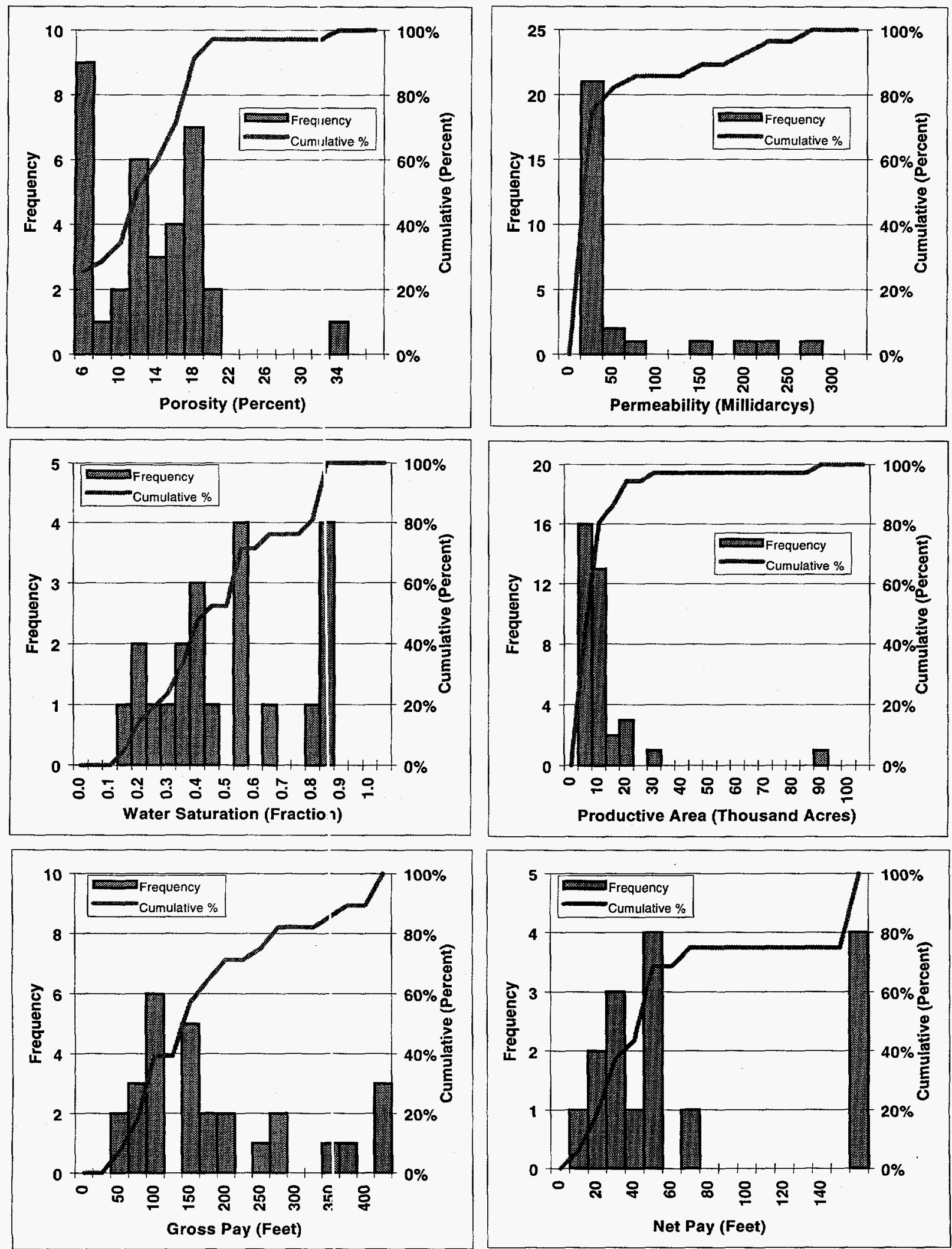

Source: Energy Information Administration, Office of oil and Gas. 


\section{Water Saturation}

A limited amount of water saturation data was available. Since porosity data appears to be consistent within selected geologic intervals and permeability data are available, the correlation developed by Morris ${ }^{1}$ and Timur $^{2}$ and updated by Coates ${ }^{3}$ and Raymer ${ }^{4}$ was used to calculate water saturations. This correlation did not hold true for all data combinations. The mode of the calculated water saturation was used as the most representative of the reservoir water saturation. The range of the water saturations was from 26.2 percent to 43.1 percent. The equation used to calculate water saturation is:

$$
S_{w}=100 \theta^{2.25} / k^{0.5}
$$

Where:

$$
\begin{aligned}
& S_{w}=\text { Irreducible water saturation (fraction) } \\
& \theta=\text { Porosity (fraction) } \\
& k=\text { Permeability (millidarcy) }
\end{aligned}
$$

\section{Productive Area}

To estimate in-place hydrocarbons by reservoir, a method was developed to determine unknown areas using the available data. The available productive area data for reservoirs were presented in several forms, and reservoir areas were available for only a portion of the fields. Data from some fields were presented as the sum of all reservoirs in the field, while some sources reported the area of the largest reservoir. When a single value was reported for field area, it was assumed that the area represented the surface area of the field or the area of the reservoir of greatest areal extent in the field.

$$
\text { Ratio }=1.0501 * n^{-0.5459}
$$

Where:

Ratio $=$ Average reservoir area divided by area of largest reservoir

$\mathrm{n}$ = Number of reservoirs in field

Even with multiple reservoir areas reduced, the areas may be overstated because of depositional discontinuities that occur in sandstone reservoirs. Reported areas may be from seismic interpretation or exploration prospect mapping which has not been more closely defined by remapping after development drilling.

\section{Reservoir Thickness}

Gross pay thickness and net pay thickness were reported in the available data sources for some of the reservoirs. Other reservoirs had either gross or net pay reported. For a few reservoirs, no pay was reported. When both gross and net pay were given, a ratio of net pay to gross pay was calculated. If only gross pay was reported, the average net to gross ratio of the corresponding geologic interval was used to estimate the net pay. When neither gross nor net pay were reported, the gross pay was defined as the difference between the depth of the geologic unit being evaluated and the depth of the next deeper geologic unit. Then net pay was determined using the net to gross ratio. If depth information was not adequate, the average net pay for the geologic interval was used for hydrocarbon in-place calculations. The range of reported gross pay in the basin was from 4 feet to 1,600 feet with a net pay range of 3 feet to 400 feet.

To estimate individual reservoir areas in fields with a single field area given, an equation was fitted to the ratio of the average reservoir area divided by the largest reservoir area in the field versus the number of reservoirs in the field for those fields with reported area data (Figure 28B). The equation determined from the graph provided a method of reducing the area of the largest reservoir (or total field area) to an average area of multiple reservoirs. The ratio determined from the following equation was multiplied by the area of the largest reservoir to determine the average area to be used for each reservoir in that field. 
Figure 28B. Correlation Function for Allocating Field Areas to Reservoir Areas, West Siberian Basin.

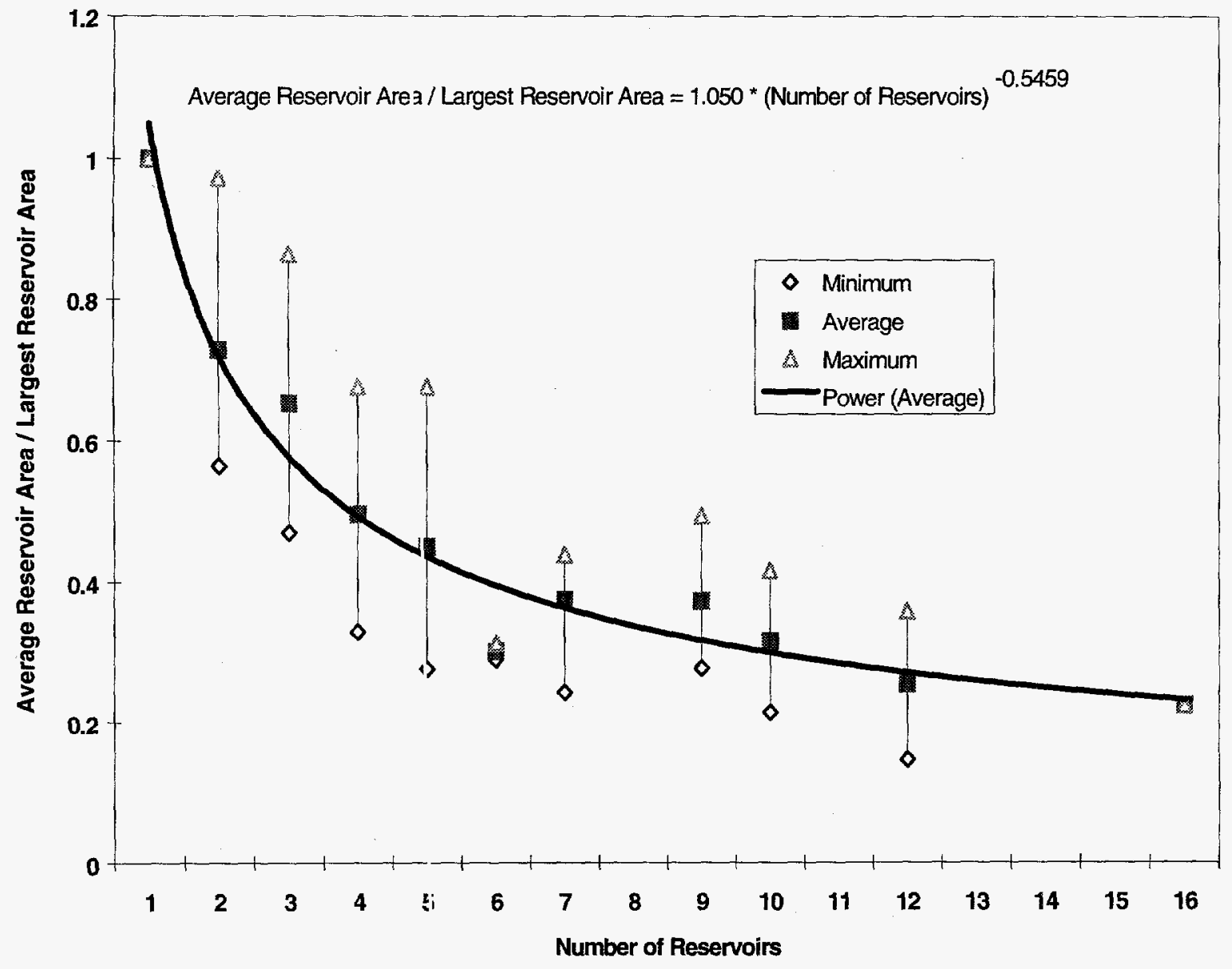

Source: Energy Information Administration, Office of Oil and Gas. 


\section{Fluid Properties}

Reservoir fluid properties were determined using correlations prepared by Muchmore $^{5}$ for use with personal computer spreadsheet software. Most of the empirical correlations programed by Muchmore are from Kartoatmodjo, ${ }^{6}$ who used a large data base to select the best correlation from various methods. Oil property correlations from Vasques and Beggs, ${ }^{7}$ water property correlations from Meehan, ${ }^{8}$ and rock compressibility correlation from $\mathrm{Hall}^{9}$ were used in this analysis. These correlations were used to calculate all properties except oil and gas specific gravities. Average oil and gas specific gravities within the major geologic intervals and Regions were used instead of the correlations. The following are the equations used in the spreadsheet calculations. A list of the symbols and nomenclature follows the equations.

\section{Oil Formation Volume Factor}

Below bubble point pressure:

$B_{\text {of }}=0.98496+0.0001 * F^{1.5}$

Where:

$F=R_{s f}^{0.755} * \rho_{g}^{0.25} * \rho_{o}^{-1.50}+0.45 T$

Above bubble point pressure:

$$
B_{o f a}=B_{o f b} * e^{c_{o}\left(P_{b}-P\right)}
$$

\section{Oil Compressibility}

Isothermal oil compressibility:

$$
\begin{gathered}
c_{o}=\frac{6.8257 x 10^{-5}}{P} * R_{s f}^{0.5002} * A P I^{0.361} \\
* T^{0.76606} * \rho_{g}^{0.35505}
\end{gathered}
$$

\section{Crude Oil Gravity}

Reported crude oil gravity was used when available. Averages of oil gravity by geologic intervals were used when there were no reported data. Reported oil gravity ranged from 33.5 degrees to 42.3 degrees API. The oil gravities of the major oil producing intervals were in the range of 36 degrees to 38 degrees API.

\section{Solution Gas-Oil Ratio}

For API gravity < 30 degrees:

$$
\begin{aligned}
R_{s f}= & 0.05958 * \rho_{g}^{0.7972} * P^{1.0014} \\
& * 10^{13.1405 \mathrm{API} /(T+460)}
\end{aligned}
$$

For API gravity $>30$ degrees:

$$
\begin{aligned}
R_{s f}= & 0.03150 * \rho_{g}^{U . / 58 /} * P^{1.0937} \\
& * 10^{11.2895 \mathrm{API} /(T+460)}
\end{aligned}
$$




\section{Bubble Point Pressure}

For API gravity $<30$ degrees:

$$
P_{b}=
$$

$\left[\frac{R_{s f}}{0.05958 * \rho_{g}^{0.7972} * 10^{13.1405 A P I /(?+460)}}\right]^{0.9986}$

For API gravity > 30 degrees:

$$
P_{b}=
$$

$\left[\frac{R_{s f}}{0.0315 * \rho_{g}^{0.7587} * 10^{11.2895 A P I /(T++460)}}\right]^{0.9143}$

\section{Gas Formation Volume Fact:or}

$$
B_{g}=\frac{5.04 Z(T+460)}{P}
$$

\section{Oil Viscosity}

Live oil above the bubble point:

$$
\begin{gathered}
\mu_{o a}=1.00081 * \mu_{o B P}+0.001127\left(P-P_{b}\right) \\
*\left(-0.006517 * \mu_{o B P}^{1.8148}+0.038 * \mu_{o B P}^{1.590}\right)
\end{gathered}
$$

Live oil below the bubble point:

$\mu_{o b}=0.06821+0.9824 * f+$

$$
0.0004034 * f^{2}
$$

Where:

$$
f=\left(0.2001+0.8428 \times 10^{-0.000845 * R_{s b}}\right)
$$

$$
* \mu_{o d}^{(0.43+0.5185 * y)}
$$

And:

$y=10^{-0.00081 * R_{s b}}$

Live oil viscosity at the bubble point:

$$
\mu_{o B P}=\mu_{o b} \text { at } R_{s b}=R_{s i}
$$

Dead oil viscosity:

$$
\begin{aligned}
& \mu_{o d}=16 X 10^{8} * T^{-2.8177} * \\
& (\log A P I)^{5.7526 * \log (T)-26.9718}
\end{aligned}
$$

\section{Rock Compressibility}

$$
c_{r}=13.172 \times 10^{-6} \theta^{-0.4317}
$$

Where:

$$
\theta=\text { Porosity }
$$




\section{Water Compressibility}

$$
\begin{gathered}
c_{w}=\frac{A+(B * T)+\left(C * T^{2}\right)}{10^{6}} \\
* G S C * S C
\end{gathered}
$$

Where:

$$
\begin{aligned}
A= & 3.8546-(0.000134 * P) \\
B= & -0.01052+\left(4.77 \times 10^{-7} * P\right) \\
C= & 3.9267 \times 10^{-6}-\left(8.8 \times 10^{-10} * P\right) \\
G S C= & 1+\left(8.9 \times 10^{-3}\right)+R_{s w} \\
S C= & {\left[-0.052+\left(2.7 \times 10^{-4} * T\right)\right.} \\
& -\left(1.14 \times 10^{-6} * T^{2}\right) \\
& \left.+\left(1.121 \times 10^{-9} * T^{3}\right)\right] \\
& * \% N a C l^{0.7}+1
\end{aligned}
$$

\section{Nomenclature}

$\mathrm{API}=$ American Petroleum Institute.

$B_{\text {ofa }}=$ Oil formation volume factor above bubble point pressure (reservoir barrels / stock tank barrel)

$B_{\mathrm{olb}}=$ Oil formation volume factor at bubble point (reservoir barrels / stock tank barrel).

$B_{\text {of }}=$ Oil formation volume factor below bubble point (reservoir barrels / stock tank barrel)

$\mathrm{B}_{\mathrm{g}}=$ Gas formation volume factor (reservoir barrels / thousand cubic feet).

$c_{0}=$ Isothermal oil compressibility (pounds I square inch ${ }^{-1}$ ).

$c_{w}=$ Water compressibility (pounds / square inch ${ }^{-1}$ ).

$c_{\mathrm{r}}=$ Rock compressibility (pounds / square inch ${ }^{-1}$ ).

$\mathrm{P}=$ Reservoir pressure (pounds / square inch).

$P_{b}=$ Bubble point pressure (pounds / square inch).

$\mathbf{R}_{\mathrm{si}}=$ Gas in solution at initial pressure (cubic feet / stock tank barrel).

$R_{s b}=$ Gas in solution at bubble point pressure (cubic feet / stock tank barrel).

$R_{s f}=$ Gas in solution at/or below bubble point pressure (cubic feet / stock tank barrel).

$\mathrm{T}=$ Reservoir temperature (degrees Fahrenheit).

$\mathrm{Z}=$ Real gas deviation factor.

$\rho_{\mathrm{o}}=$ Oil density (grams / cubic centimeter)

$\rho_{\mathrm{g}}=$ Gas specific gravity

$\mu_{\mathrm{o} a}=$ Oil viscosity above bubble point (centipoise).

$\mu_{\mathrm{ob}}=$ Oil viscosity below bubble point (centipoise).

$\mu_{\mathrm{OBP}}=$ Oil viscosity at bubble point (centipoise).

$\mu_{\mathrm{od}}=$ Dead oil viscosity (centipoise).

$\theta=$ Porosity (percent of rock volume).

$F=$ Correlation number for calculating oil formation volume factor.

$\mathrm{f}=$ Correlation number for calculating live oil viscosity.

$y=$ Correlation number for calculating live oil viscosity.

$\mathrm{SC}=$ Water salinity correction factor

GSC $=$ Gas solubility in water correction factor.

$\% \mathrm{NACl}=$ Percent sodium chloride in water. 


\section{References}

1. R.L. Morris and W. P. Biggs, Using Log

Derived Values of Water Saturation and Porosity,

Trans. SPWLA (1967).

2. A. Timur, An Investigation of Pe rmeability,

Porosity, and Residual Water Saturation

Relationships for Sandstone Reservoirs, The Log

Analyst (July - August 1968).

3. G. R. Coates and J. L. Dumanoir, A New

Approach to improved Log-Derived permeability, The Log Analyst (January - February 1974).

4. L. L. Raymer, Elevation and Hydrocarbon Density Correction for Log-Derived Permeability Relationships, The Log Analyst (May .. June 1981).

5. D. Muchmore, "Macros Help Solve Common Petroleum Engineering Calculations," Pil and Gas Journal (November 6, 1995) pp. 38-44.

6. T. Kartoatmodjo and Z. Schmidt, "Large Data Bank Improves Crude Physical Properly

Correlations," Oil and Gas Journal (July 4, 1994) pp.

51-55.

7. M. E. Vasques and H. D. Beggs, "Correlations for Fluid Physical Property Prediction," JPT (June, 1980) pp 968-970.

8. D. N. Meehan, "A Correlation for water Compressibility," Petroleum Engineer International, (November, 1980) pp 125-126.

9. H. N. Hall, "Compressibility of Reservoir Rocks," Transactions AIME, vol.198, p.309. 
Appendix C

Calculation Procedures 



\section{Calculation Procedures}

\section{Hydrocarbons in Place}

The oil and gas in place were calculated for each reservoir identified as oil or gas bearing in a field. The volume of oil or gas per acre foot of reservoir was calculated and then multiplied by the number of acres and the net pay thickness of the reservoir .

\section{Initial Oil in Place}

$$
I O I P=\frac{7758 * \theta *\left(1-S_{w}\right)}{B_{o}}
$$

\section{Initial Gas in Place}

$$
I G I P=\frac{7758 * \theta *\left(1-S_{w}\right)}{B_{g}}
$$

Where:

IOIP = Initial oil in place (stock tank barrels / acrefoot)

IGIP = Initial gas in place (thousand cubic feet $/$ acre-foot)

$7758=$ Barrels per acre-foot

$\theta=$ Porosity (fraction)

$\mathrm{S}_{\mathrm{w}} \quad$ = Water saturation (fraction)

$B_{0}=$ Oil formation volume factor (reservoir barrels / stock tank barrel)

$\mathrm{B}_{\mathrm{g}}=$ Gas formation volume factor (reservoir barrels / thousand cubic feet)

\section{Gas volume}

$$
V G=\frac{I G I P * A * h}{1,000,000}
$$

Where:

VO $=$ Oil volume (million barrels)

$\mathrm{VG}=$ Gas volume (billion cubic feet)

IOIP = Initial oil in place (stock tank barrels / acrefoot)

IGIP = Initial gas in place (thousand cubic feet / acre-foot)

$\mathrm{A}=$ Area (acres)

$\mathrm{h}=$ Net pay (feet)

A recovery efficiency was applied to the volume of each reservoir to determine potential recoverable oil or gas. No consideration was given to economics of development.

\section{Primary Oil Recovery}

The fraction of the initial oil in place that would be produced by solution gas drive was calculated for each oil reservoir. The primary oil recovery factor for reservoirs with initial pressure above the bubble point pressure was calculated as the sum of the recoveries above and below the bubble point pressure. The initial oil in place for each reservoir was then multiplied by the recovery factor to determine the volume of oil recoverable under primary depletion.

\section{Oil Volume}

$$
V O=\frac{I O I P * A * h}{1,000,000}
$$




\section{Oil Recovery Above Bubble: Point}

The bubble point pressure and initia pressure were determined for each oil reservoir. If the initial pressure exceeded the bubble point pressure, an incremental recovery was calculated based on fluid expansion as the pressure dropped to the bubble point pressure. This recovery was added to the primary oil recovery that was calculated from the bubble point pressure to the abandonment pressure.

$$
R_{a P b}=c_{t}\left(P_{i}-P_{b}\right)
$$

Where:

$$
\begin{aligned}
& \mathrm{R}_{\mathrm{aPb}}=\text { Fraction of IOIP recovered } \\
& \mathrm{P}_{\mathrm{i}}=\text { Initial reservoir pressure }(\mathrm{psi}) \\
& \mathrm{P}_{\mathrm{b}}=\text { Bubble point pressure }(\mathrm{psi}) \\
& \mathrm{c}_{\mathrm{t}}=\text { Total system compressibility }\left(\mathrm{psi}^{-1}\right)
\end{aligned}
$$

And:

$$
c_{t}=c_{w} * S_{w}+c_{o} * S_{o}+c_{r}
$$

Where:

$$
\begin{aligned}
& c_{\mathrm{w}}=\text { Water compressibility }\left(\mathrm{psi}^{-1}\right. \text {, } \\
& \mathrm{c}_{\mathrm{o}}=\text { Oil compressibility }\left(\mathrm{psi}^{-1}\right) \\
& \mathrm{c}_{\mathrm{r}}=\text { Rock compressibility }\left(\mathrm{psi}^{-1}\right) \\
& \mathrm{S}_{\mathrm{w}}=\text { Water saturation (fractior) } \\
& \mathrm{S}_{\mathrm{o}}=\text { Oil saturation (fraction) }
\end{aligned}
$$

\section{Oil Recovery Below the Bubble Point}

Primary oil recovery of oil below the bulbble point was calculated for each reservoir in units of barrels per acre foot; therefore, the area and net thiclness of each reservoir were multiplied by the calculatid recovery to determine the recovery in stock tank barjels from each reservoir identified as oil bearing. T.he statistical correlation for primary recovery was taken from a study by the American Petroleum Institute.'

$$
\begin{gathered}
R_{p r i}=3244\left[\frac{\theta\left(1-S_{w}\right)}{B_{o b}}\right]^{1.1611} *\left[\frac{k}{\mu_{o b}}\right]^{0.097 !} \\
*\left[S_{w}\right]^{0.3722} *\left[\frac{P_{b}}{P_{a}}\right]^{0.1741}
\end{gathered}
$$

Where:

$\mathrm{R}_{\mathrm{pri}}=$ Primary oil recovery below bubble point (Barrels / acre-foot)

$\theta=$ Porosity (fraction)

$S_{w}=$ Water saturation (fraction)

$B_{o b}=$ Oil formation volume factor at bubble point

$\mathrm{k}=$ Permeability (darcys)

$\mu_{\mathrm{ob}}=$ Oil viscosity at bubble point (centipoise)

$\mathrm{P}_{\mathrm{b}}=$ Bubble point pressure (psi)

$\mathrm{P}_{\mathrm{a}}=$ Abandonment pressure (psi)

And:

$\mathrm{P}_{\mathrm{a}}=0.1(\mathrm{psi} / \mathrm{ft}) *$ Depth to reservoir (feet)

\section{Enhanced Oil Recovery}

Many of the producing fields are being waterflooded to enhance oil recovery. Indications are that the waterfloods are inefficient by U.S. standards with high producing water-oil ratios and low incremental recovery. The extent of field development (well spacing), multiple reservoir fields, stratification of reservoirs, and lateral discontinuities would adversely effect the waterflood recovery efficiency. All of these conditions exist in the fields of the basin. Therefore, it is assumed that enhanced recovery will contribute an amount equal to the calculated primary oil recovery with the following limitations. Oil reservoirs in predominantly gas fields and the Bazhenov shale formation will not be waterflooded. Also, no reservoirs below the Jurassic section or with permeability less than 10 millidarcys will be subject to enhanced recovery processes such as waterflooding.

\section{Associated-Dissolved Gas Recovery}

Associated-dissolved gas recovery was calculated by multiplying the solution gas-oil ratio at the initial pressure by the recoverable oil volume. The initial pressures of the reservoirs were near the calculated bubble point pressures, and the reported initial gas-oil ratios confirmed the calculations of solution gas-oil ratios and bubble point pressures. No attempt was made to determine the recovery of the solution gas that was liberated from the remaining oil in place by pressure depletion. When the initial gas-oil ratio of a field was greater than the solution gas-oil ratio, the reported gas-oil ratio was used to calculate associated gas recovery. In several fields, an associated gas cap appears to affect the producing gas-oil ratio. Although the associated-dissolved gas volume for the basin is 
large, the amount of associated gas is minor compared to the amount of nonassociated gas in the basin.

\section{Nonassociated Gas Recovery}

Recoverable nonassociated gas was calculated as the difference between the initial gas in place and the remaining gas in place at an abandonment pressure. The abandonment pressure was calculated by multiplying an assumed abandonment gradient of 0.1 pounds per square inch per foot by the depth to the reservoir, which is consistent with the abandonment pressure used for calculating primary oil recovery.

\section{Condensate Recovery}

Significant condensate is produced in the transition area of the basin between the oil reservoirs in the central basin and the nonassociated gas reservoirs in the northern part of the basin. Condensate recovery was calculated using the yield in barrels of condensate per million cubic feet of gas produced as reported from gas reservoir tests. When data were not available, no recoverable condensate was assigned. Condensate volumes were added to oil volumes in the projections of future potential.

\section{Future Projections}

Future discoveries were projected using a modified logistics equation to fit the discovery history. ${ }^{2}$ Total recovery from the basin was calculated by adding the undiscovered resources estimated by the USGS to the discovered reserves estimated in this analysis. Cumulative discovered reserves were calculated at each year in the future, and an iterative scheme was used to schedule annual production. Cumulative production was subtracted from the discovered reserves in each year to estimate remaining reserves. Production for the next year was then calculated based on a reserves-toproduction ratio (R/P) that was previously determined. This production was added to the previous cumulative production and the process was repeated until the $R / P$ equaled 1.0 (depletion).

The end-point of the projected $R / P$ ratio was taken to be the last calculated discovery based on the logistics equation. For the oil case an end year of 2100 was used, and for gas; the final year was 2200. The historical R/P ratio for oil has been declining exponentially since 1980 . Therefore an extrapolation of that trend was used to determine the future $\mathrm{R} / \mathrm{P}$ ratio. The gas $\mathrm{R} / \mathrm{P}$ ratio was also declining but a consistent trend had not been established. Therefore, an exponential decline from the current gas $\mathrm{R} / \mathrm{P}$ to a final $\mathrm{R} / \mathrm{P}$ of 1.0 in the year 2200 was used to approximate the productive capacity of the gas reservoirs (Figures 1C and $2 \mathrm{C}$ ).

The logistic equation that was used in projecting cumulative discoveries is from the work of Hubbert, ${ }^{3}$ with modifications by EIA. ${ }^{4}$

$$
Q_{D}(t)=\frac{Q_{\max }}{1+e^{\left[\left(B_{1} S+(1-S) B_{4}\right)\left(t-t_{0}+B_{2}\right)\right]}}
$$

Where:

$$
\begin{aligned}
& \mathrm{Q}_{D}(\mathrm{t})=\text { Cumulative discoveries at time } \mathrm{t} \\
& \text { (remaining discovered reserves plus } \\
& \text { cumulative production). } \\
& \mathrm{Q}_{\max }=\text { Ultimate recovery. } \\
& \mathbf{B}_{1}=\mathbf{A} \text { constant negative parameter that is } \\
& \text { slowly switched off. } \\
& \mathrm{S}=\text { The switching function which is equal } \\
& \text { to the quantity } \mathrm{e}_{3}^{\mathrm{B}(\mathrm{t}-\mathrm{t})} \mathrm{0} \text {. } \\
& \mathrm{B}_{2} \quad=\mathrm{A} \text { constant negative parameter that } \\
& \text { controls the timing of maximum } \\
& \text { theoretical production capability (the } \\
& \text { peak of the theoretical } \\
& \text { maximum production capability occurs } \\
& \text { approximately at the time when } \\
& \mathrm{t}=\mathrm{t}_{0}-\mathrm{B}_{2} \text { ). } \\
& \mathrm{B}_{3}=\mathrm{A} \text { constant negative parameter that } \\
& \text { controls the rate of switch. } \\
& \mathrm{B}_{4} \quad=\text { The estimated decline rate from known } \\
& \text { deposits which, in turn, dictates the } \\
& \text { annual additions to proved reserves in } \\
& \text { the latter stages of development, also } \\
& \text { a negative parameter. } \\
& \left(t-t_{0}\right)=\text { The time after some reference period, } \\
& t_{0} \text {. } \\
& \text { e } \quad=\text { The base of the Naperian logarithms. }
\end{aligned}
$$


Figure 1C. Remaining Reserves / Annual Production Ratio (R/P) for Crude Oil Projection, West Siberian Basirı

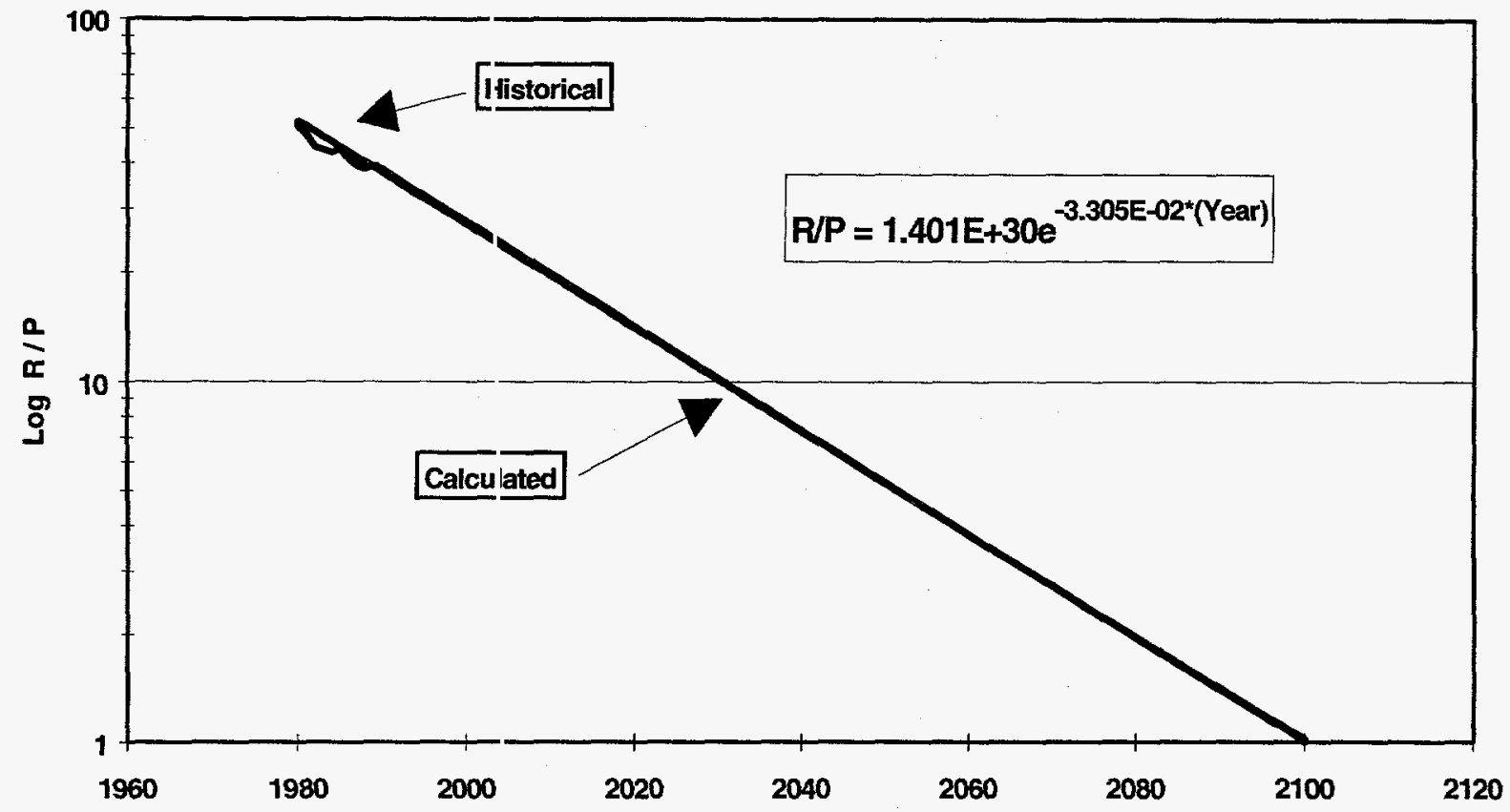

Source: Energy Information Administ|ation, Office of Oil and Gas.

Figure 2C. Remining Reserves / Annual Production Ratio (R / P) for Gas Projection, West Siberian Basin

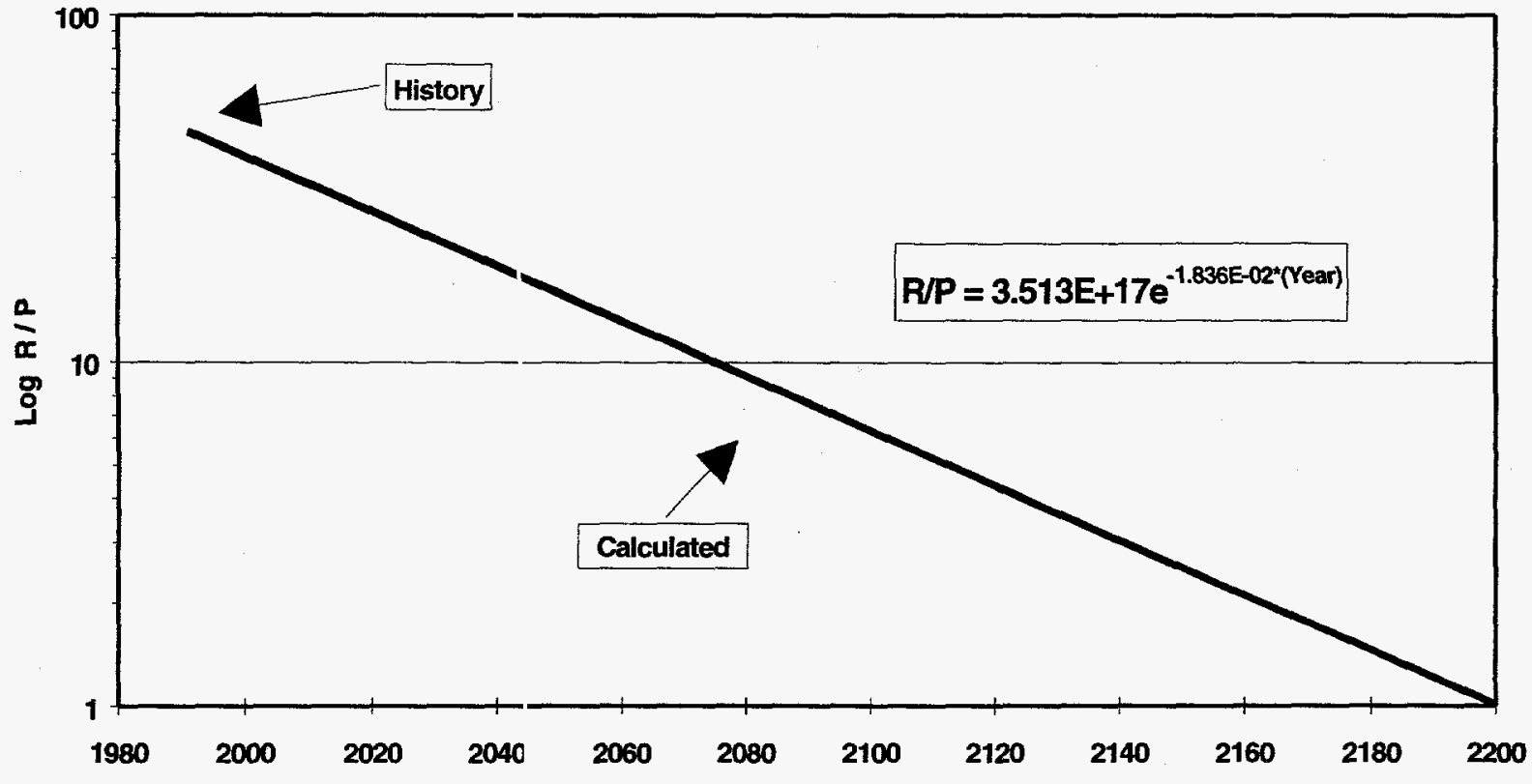

Source: Energy Information Administration, Office of Oil and Gas. 


\section{References}

1. American Petroleum Institute, A Statistical Study of Recovery Efficiency, API BUL D14 (Washington DC, October, 1967).

2. SigmaPlot Scientific Graphing Software,

Transforms and Curve Fitting, Revision SPW 1.0

(United States, July 1993).

3. M.K. Hubbert, U. S. Energy Resources, A Review of 1972, Serial no. 93-40 (92-72), Part I, 1974 (U.S.

Printing Office, Washingto DC).

4. Energy information Administration, Report on the Petroleum Resources of the Federal Republic of Nigeria, DOE/AA - 0008 (Washington, DC, October 1979). 
Appendix D

Field Summaries 



\section{Field Summaries}

Tables 1D and 2D lists the fields of the West Siberian Basin in alphabetical order. Table 1D shows the location of each field by Region of the basin and the degrees of longitude and latitude. The discovery date, producing status, and primary product are also included in Table 1D. The calculated ultimate recovery of crude oil, associated-dissolved gas, nonassociated gas and condensate from each field are tabulated in Table 2D. The oil and condensate are reported in millions of barrels with the associated and nonassociated gas reported in billions of cubic feet.

Tables 3D through 24D report the same information by Regions of the basin. Each list of fields in the Regions is sorted alphabetically. 
Table 1D. Basic Field Information, West Siberian Basin (Sorted Alphabetically by Field Name).

\begin{tabular}{|c|c|c|c|c|c|c|}
\hline Field Name & Reylion & $\begin{array}{l}\text { North } \\
\text { Latitude } \\
\text { (degrees) }\end{array}$ & $\begin{array}{l}\text { East } \\
\text { Latitude } \\
\text { (degrees) }\end{array}$ & $\begin{array}{c}\text { Discovery } \\
\text { Date }\end{array}$ & $\begin{array}{c}\text { Producing } \\
\text { Status }\end{array}$ & $\begin{array}{l}\text { Primary } \\
\text { Product }\end{array}$ \\
\hline Achimovskoye (Achimov) & DB & 60.07 & 75.34 & 1981 & $\mathrm{SI}$ & Oil \\
\hline Aganskoye & OB & 61.47 & 76.02 & 1965 & PS & Oil \\
\hline Aganskoye Yuzhnoye & $O B$ & 61.30 & 75.88 & 1980 & PS & Oil \\
\hline Aganskoye Zapadnoye & $O B$ & 61.45 & 77.02 & 1981 & PP & Oil \\
\hline Akaytemskoye & UKN & & & 1991 & Si & Gas \\
\hline Alekhinskoye & $O B$ & 62.16 & 71.88 & 1971 & PS & Oil \\
\hline Alenkinskoye & $O B$ & 60.43 & 77.21 & 1964 & SI & Oil \\
\hline Alyasovskoye Severnoye & UR & 64.09 & 65.49 & 1956 & SI & Gas \\
\hline Alyasovskoye Yuzhnoye & UR & 64.06 & 65.44 & 1956 & SI & Gas \\
\hline Anomalnoye & UKN & & & 1992 & SI & Oil \\
\hline Antipayutaskoye & (̇̀YY & 68.93 & 77.38 & 1978 & SI & Gas \\
\hline Apakapurskoye & NP & 63.78 & 76.44 & 1989 & SI & Oil \\
\hline Aprel'skoye & $F: R$ & 62.38 & 68.63 & 1982 & SI & Oil \\
\hline Archinskoye & KA & 57.49 & 78.50 & 1985 & S! & Oil \\
\hline Ariolskoye & V'A & 61.34 & 78.52 & 1992 & SI & Oil \\
\hline Arkticheskoye & Y'A & 69.74 & 70.74 & 1968 & DV & Gas \\
\hline Asomkinskoye & C)B & 61.01 & 73.84 & 1981 & PS & Oil \\
\hline Asomkinskoye Vostochnoye & CIB & 61.30 & 75.83 & 1990 & SI & Oil \\
\hline Asomkinskoye Yuzhnoye & CIB & 60.91 & 73.88 & 1988 & DV & Oil \\
\hline Asomkinskoye Zapadnoye & CIB & 60.90 & 73.51 & 1988 & SI & Oil \\
\hline Ay-Yaunskoye & $K A$ & 59.31 & 72.76 & 1968 & $\mathrm{SI}$ & Oil \\
\hline Ayeganskoye & NIP & 61.86 & 77.42 & 1985 & PS & Oil \\
\hline Aykuruskoye & KA & 59.80 & 73.72 & 1988 & SI & Oil \\
\hline \multicolumn{7}{|l|}{ Aypim Lobat-Yuganskoye } \\
\hline (Ai Pim) & $C \mid B$ & 62.23 & 71.14 & 1971 & PP & Oil \\
\hline \multicolumn{7}{|l|}{ Ayvasedopurskoye Severnoye } \\
\hline (Tarasovskoye Sev.) & NP & 64.60 & 77.67 & 1990 & SI & Oil \\
\hline Bakhilovskoye & PT & 62.47 & 79.65 & 1983 & PS & Oil \\
\hline Balykskoye Yuzhnny & $C B$ & 60.50 & 72.50 & 1964 & PS & Oil \\
\hline Barsukovskoye & NP & 64.42 & 75.50 & & PP & Gas \\
\hline Barsukovskoye Zapadnoye & NP & 64.25 & 75.50 & & & Oil \\
\hline Baydaratskoye & YA & 69.72 & 67.94 & 1987 & SI & Gas \\
\hline Beloyarskoye & PA & 58.68 & 80.06 & 1962 & $\mathrm{SI}$ & Gas \\
\hline Beregovoye (W. Siberia) & PT & 65.87 & 78.97 & 1982 & SI & Gas \\
\hline Berezovskoye (Tyumen) & UR & 63.94 & 65.04 & 1953 & PP & Gas \\
\hline Bittemskoye & OB & 61.92 & 71.23 & 1989 & SI & Oil \\
\hline Bol'shoye & $\mathrm{Fq}$ & 62.90 & 67.27 & 1984 & SI & Oil \\
\hline \multicolumn{7}{|l|}{ Bol'shoye Kruzenshternskoye } \\
\hline (Kruzenshternskoye) & YA & 70.00 & 69.00 & 1976 & DV & Gas \\
\hline Boloshekotukhtinskoye(Kotukhta & a) $O B$ & & & 1972 & SI & Oil \\
\hline Bovanenko & Y.A & 70.40 & 68.50 & 1971 & PP & Gas \\
\hline Bovanenko Severnyy & YA & 70.83 & 68.12 & 1988 & SI & Gas \\
\hline Bovanenko Vostochnoye & YA & 70.73 & 69.22 & 1983 & SI & Gas \\
\hline Bugornaya-Vostochnaya & GY & 69.60 & 74.60 & 1990 & SI & Gas \\
\hline Bystrinskoye (Bystrin) & OB & 61.46 & 72.24 & 1964 & PS & Oil \\
\hline Chakhloneyskoye & $\mathrm{OB}$ & 60.52 & 75.80 & 1988 & DV & Oil \\
\hline Chanchar Severnoye & UZ & 60.61 & 64.16 & & SI & Oil \\
\hline Chaselskoye Severnoye & P厂 & 66.04 & 79.33 & 1987 & SI & Gas \\
\hline Chatylkynskoye & $\mathrm{Pr}$ & 63.44 & 80.99 & 1989 & SI & Oil \\
\hline Chebachyeskoye & VA & 60.62 & 78.83 & 1966 & DV & Oil \\
\hline Cheremshanskoye Yuzhnoye & VA & 58.90 & 76.85 & 1970 & SI & Oil \\
\hline Chernichnoye & $\mathrm{Pr}$ & 65.54 & 81.97 & 1985 & SI & Oil \\
\hline
\end{tabular}


Table 1D. Basic Field Information, West Siberian Basin (Sorted Alphabetically by Field Name) (Continued)

\begin{tabular}{|c|c|c|c|c|c|c|}
\hline Field Name & Region & $\begin{array}{l}\text { North } \\
\text { Latitude } \\
\text { (degrees) }\end{array}$ & $\begin{array}{c}\text { East } \\
\text { Latitude } \\
\text { (degrees) }\end{array}$ & $\begin{array}{c}\text { Discovery } \\
\text { Date }\end{array}$ & $\begin{array}{c}\text { Producing } \\
\text { Status } \\
\end{array}$ & $\begin{array}{l}\text { Primary } \\
\text { Product }\end{array}$ \\
\hline Chernogorskoye & $O B$ & 61.50 & 76.67 & 1972 & PP & Oil \\
\hline Chistinnoye & $O B$ & 59.82 & 75.99 & 1985 & SI & Oil \\
\hline Chkalovskoye & VA & 59.69 & 78.74 & 1977 & PS & Oil \\
\hline Chuelskoye & UR & 63.86 & 65.93 & 1958 & SI & Gas \\
\hline Chukhlorskoye & $\mathrm{OB}$ & 61.87 & 76.53 & 1989 & $\mathrm{SI}$ & Oll \\
\hline Chumpaskoye & $\mathrm{OB}$ & 61.25 & 75.11 & 1979 & PS & Oil \\
\hline Chupal'skoye & OB & 60.15 & 72.45 & 1971 & DV & Oil \\
\hline Chupal'skoye Severnyy & OB & 60.29 & 72.68 & 1977 & $\mathrm{SI}$ & Oil \\
\hline Chvorovoye (Vasyuganskiy) & $\mathrm{KA}$ & 58.58 & 76.95 & 1980 & $\mathrm{SI}$ & Oil \\
\hline Danilovskoye & UR & 60.93 & 64.11 & 1966 & PS & Oil \\
\hline Danilovskoye Severnoye & UR & 61.07 & 63.95 & 1983 & PS & Oil \\
\hline Danilovskoye Vostochnoye & UR & 61.00 & 64.00 & 1983 & $\mathrm{PP}$ & Oil \\
\hline Danilovskoye Zapadnoye & UR & 61.00 & 64.00 & 1966 & PP & Oil \\
\hline Dekabr'skoye & FR & 62.02 & 70.25 & 1969 & SI & Oil \\
\hline Deminskoye & UR & 64.00 & 65.00 & 1955 & SI & Gas \\
\hline Demyanskoye Severnoye & $\mathrm{KA}$ & 59.53 & 70.81 & 1988 & SI & Oil \\
\hline Dobrovol'skoye & NP & 65.37 & 77.45 & 1990 & SI & Oil \\
\hline Druzhnoye & $\mathrm{OB}$ & 62.45 & 74.62 & 1982 & PS & Oil \\
\hline Duklinskoye & $\mathrm{KA}$ & 59.33 & 75.80 & 1990 & PP & Oil \\
\hline Dunayevskoye & OB & 61.62 & 73.20 & 1986 & PS & Oil \\
\hline Dvoynoye & PA & 58.83 & 79.45 & 1986 & SI & Oil \\
\hline Em-Yakhtinskoye & GY & 68.83 & 76.45 & 1976 & SI & $\mathrm{GC}$ \\
\hline Enitorskoye & VA & 61.52 & 78.93 & 1982 & SI & Oil \\
\hline Enitorskoye Yuzhnoye & VA & 61.40 & 78.97 & 1988 & SI & Oil \\
\hline Erginskoye & FR & 60.70 & 69.29 & 1983 & SI & Oil \\
\hline Erginskoye Vostochnoye & FR & 60.69 & 69.82 & 1988 & SI & Oil \\
\hline Fainskoye & $\mathrm{OB}$ & 61.10 & 73.75 & 1989 & $P P$ & Oil \\
\hline Fedorovskoye & $\mathrm{OB}$ & 61.39 & 73.12 & 1971 & PS & Oil \\
\hline Fedyushkinskoye & KA & 57.77 & 76.31 & 1985 & PP & Oil \\
\hline Fedyushkinskoye Severnoye & KA & 57.88 & 76.35 & 1987 & SI & Oil \\
\hline \multicolumn{7}{|l|}{ Festivalnoye } \\
\hline (Tomsk)(Aykagol'skoye) & VA & 58.28 & 77.28 & 1971 & $\mathrm{SI}$ & Oil \\
\hline Festivalnoye (Tyumen)(Kamy) & PT & 63.73 & 79.48 & 1985 & DV & Oil \\
\hline Festivalnoye Yuzhno & VA & 58.20 & 77.28 & 1969 & $\mathrm{SI}$ & Oil \\
\hline Filippovskoye & UR & 60.91 & 64.83 & 1967 & PS & Oil \\
\hline Fobosskoye & $O B$ & 60.87 & 77.62 & 1988 & DV & Oil \\
\hline Frolovskoye Vostochnoye & FR & 60.90 & 69.81 & 1987 & SI & Oil \\
\hline Galyanovskoye & FR & 61.50 & 68.29 & 1982 & SI & Oil \\
\hline Gaz-Saleskoye & PT & 67.40 & 80.43 & 1989 & $\mathrm{SI}$ & Gas \\
\hline Geofizicheskoye & GY & 69.86 & 73.69 & 1975 & SI & Gas \\
\hline Gerasimovskoye & KA & 57.65 & 78.92 & 1983 & PP & Oil \\
\hline Glukhovskoye & $\mathrm{KA}$ & 58.03 & 76.78 & 1983 & $\mathrm{SI}$ & Oil \\
\hline Golevoye & $\mathrm{OB}$ & 61.71 & 76.25 & 1988 & SI & Oil \\
\hline Gornoye (Tyumen) & UR & 62.40 & 63.50 & 1962 & DV & Gas \\
\hline Gorshkovskoye Zapadnoye & FR & 61.62 & 70.19 & 1988 & SI & Oil \\
\hline Gorstovoye & VA & 60.54 & 78.36 & 1987 & $\mathrm{SI}$ & Oil \\
\hline Gribnoye & $\mathrm{OB}$ & 62.56 & 74.86 & 1982 & DV & Oil \\
\hline Grushevoye & VA & 59.38 & 77.13 & 1987 & SI & Oil \\
\hline Gubkinskoye Severnyy & NP & 65.00 & 76.70 & 1980 & SI & Oil \\
\hline \multicolumn{7}{|l|}{ Gubkinskoye } \\
\hline (Gubkin Sev., Prisklonoye) & NP & 65.00 & 76.70 & 1965 & PP & Gas \\
\hline
\end{tabular}


Table 1D. Basic Field information, West Siberian Basin (Sorted Alphabetically by Field Name) (Continued)

\begin{tabular}{|c|c|c|c|c|c|c|}
\hline Field Name & Region & $\begin{array}{l}\text { North } \\
\text { Latitude } \\
\text { (degrees) }\end{array}$ & $\begin{array}{l}\text { East } \\
\text { Latitude } \\
\text { (degrees) }\end{array}$ & $\begin{array}{c}\text { Discovery } \\
\text { Date }\end{array}$ & $\begin{array}{l}\text { Producing } \\
\text { Status } \\
\end{array}$ & $\begin{array}{l}\text { Primary } \\
\text { Product }\end{array}$ \\
\hline Gun-Yeganskoye & $\mathrm{Ol3}$ & 61.62 & 77.44 & 1973 & PS & Oil \\
\hline Gustorechenskoye & $\mathrm{KA}$ & 58.07 & 73.55 & 1992 & $\mathrm{SI}$ & Oil \\
\hline Gydanskoye & G' & 70.44 & 76.30 & 1978 & $\mathrm{Sl}$ & Gas \\
\hline Igol'sko-Talovoye & $\mathrm{KA}$ & 57.64 & 76.24 & 1977 & PS & Oil \\
\hline Igrimskoye Severnoye & UF & 63.13 & 64.44 & 1959 & ABND & Gas \\
\hline Igrimskoye Yuzhnoye & UR & 63.09 & 64.34 & 1961 & PP & Gas \\
\hline Ikilorskoye & OP3 & 62.11 & 73.93 & 1981 & $\mathrm{SI}$ & Oil \\
\hline Imlorskoye & OE3 & 63.00 & 73.87 & & SI & Oil \\
\hline $\begin{array}{l}\text { Imlorskoye Zpapadnny } \\
\text { Inqaskove (Inqinsk) }\end{array}$ & OB3 & 62.97 & 73.50 & & SI & Oil \\
\hline (Krasnoleninskoye) & $\mathrm{FF}_{\mathrm{i}}$ & 61.57 & 66.57 & 1975 & SI & Oil \\
\hline Ininskoye & VA. & 61.05 & 78.83 & 1990 & SI & Oil \\
\hline lokhturskoye Severnoye & PT & 63.72 & 79.14 & 1987 & SI & Oil \\
\hline Istochnoye & OES & 63.17 & 73.83 & & SI & Oil \\
\hline It'yakhskoye & FF & 62.30 & 68.97 & 1992 & SI & Oil \\
\hline Izvestinskoye & $N^{\prime}$ & 64.52 & 76.21 & 1990 & PP & Oil \\
\hline Kalchinskoye & KA & 59.20 & 69.99 & 1990 & PP & Oil \\
\hline Kalchinskoye Severnoye & KA & 59.30 & 70.00 & 1991 & SI & Oil \\
\hline Kalinovoye & KA & 57.42 & 79.10 & 1973 & SI & Gas \\
\hline Kalinovoye Severnoye & KA & 57.51 & 79.01 & 1980 & Si & Oil \\
\hline Kalinovoye Vostochnoye & KA & 57.44 & 79.21 & 1973 & SI & Oil \\
\hline Kamennomysskoye & YA & 68.41 & 73.34 & 1981 & DV & Gas \\
\hline Kamennoye(Krasnoleninskoye) & e) FR & 61.65 & 67.32 & 1962 & PS & Oil \\
\hline Kamynskoye & $\mathrm{OE}$ & 62.17 & 71.62 & 1982 & PS & Oil \\
\hline Kamynskoye Severnoye & $\mathrm{OB}$ & 62.29 & 70.79 & 1989 & SI & Oil \\
\hline Kamynskoye Yuzhnoye & $\mathrm{OB}$ & 61.80 & 70.50 & 1989 & SI & Oil \\
\hline Karabashskoye(Leninskoye) & UR & 58.64 & 65.92 & 1964 & SI & Gas \\
\hline Karamovskoye & $\mathrm{OB}$ & 63.25 & 74.44 & 1975 & PS & Oil \\
\hline Karamovskoye Severnoye & $\mathrm{OB}$ & 63.31 & 74.58 & 1975 & PP & Oil \\
\hline Karasevskoye (Tomsk) & $\mathrm{KA}$ & 58.43 & 76.04 & 1985 & SI & Oil \\
\hline Karasevskoye (Tyumen) & NP & 64.73 & 73.86 & 1989 & SI & Oil \\
\hline Karasevskoye Severnoye & $\mathrm{KA}$ & 58.48 & 76.06 & 1988 & SI & Oil \\
\hline Karasevskoye Zapadnoye & KA & & & & SI & Oil \\
\hline Karayskoye & KA & 57.70 & 75.96 & 1980 & DV & Oil \\
\hline Karayskoye Zapadnoye & KA & 57.75 & 75.62 & 1983 & SI & Oil \\
\hline Karempostskoye & FR & 62.18 & 66.18 & 1986 & SI & Oil \\
\hline Kartop'ya & UR & 61.10 & 65.31 & 1967 & SI & Oil \\
\hline Kartopya Zapadnoye & UR & 60.13 & 65.28 & 1967 & SI & Oil \\
\hline Kartopya-Okhanskoye & UR & 61.05 & 65.55 & 1967 & PS & Oil \\
\hline Karyaunskoye & $\mathrm{OB}$ & 62.03 & 72.27 & 1980 & SI & Oil \\
\hline Katyl'ginskoye & KA & 59.14 & 76.29 & 1965 & PS & Oil \\
\hline Katyl'ginskoye Zapadnoye & KA & 59.07 & 76.07 & 1972 & PS & Oil \\
\hline Kayumovskoye & UR & 60.78 & 65.39 & 1971 & SI & Oil \\
\hline Kazanskoye & KA & 57.21 & 79.34 & 1967 & SI & Gas \\
\hline Kazantsevskoye(UstYenisey) & GY & 69.70 & 83.30 & 1969 & SI & Gas \\
\hline Kazymskoye Severnoye & FR & 63.98 & 67.41 & 1965 & SI & Gas \\
\hline Kechimovskoye & OB & 61.80 & 74.50 & & SI & Oil \\
\hline Kechimovskoye Yuzhnoye & $\mathrm{OB}$ & 61.17 & 74.37 & & SI & Oil \\
\hline Ketovskoye & $\mathrm{OB}$ & 60.85 & 75.13 & 1980 & PS & Oil \\
\hline Khadyryakhaskoye & PT & 65.30 & 79.53 & 1989 & SI & Gas \\
\hline Khadyryakhaskoye Yuzhnoye & PT & 65.03 & 79.98 & 1990 & SI & Oil \\
\hline
\end{tabular}


Table 1D. Basic Field Information, West Siberian Basin (Sorted Alphabetically by Field Name) (Continued)

\begin{tabular}{|c|c|c|c|c|c|c|}
\hline Field Name & Region & $\begin{array}{l}\text { North } \\
\text { Latitude } \\
\text { (degrees) }\end{array}$ & $\begin{array}{c}\text { East } \\
\text { Latitude } \\
\text { (degrees) }\end{array}$ & $\begin{array}{c}\text { Discovery } \\
\text { Date }\end{array}$ & $\begin{array}{c}\text { Producing } \\
\text { Status } \\
\end{array}$ & $\begin{array}{l}\text { Primary } \\
\text { Product }\end{array}$ \\
\hline Khalmerpayutaskoye & PT & 67.75 & 81.15 & 1989 & SI & Gas \\
\hline Khambateyskoye & GY & 68.77 & 72.90 & 1987 & si & Gas \\
\hline Khancheyskoye (or Khangey) & PT & 64.82 & 79.41 & 1990 & SI & Gas \\
\hline \multicolumn{7}{|l|}{ Khanty-Mansiyskoye } \\
\hline (Tsentralnoye) & FR & 61.04 & 69.21 & 1986 & SI & Oil \\
\hline Kharam-Pur Yuzhnoye & PT & 63.85 & 79.87 & 1981 & SI & Gas \\
\hline Kharampur (Kharampur Yuz.) & PT & 64.22 & 79.65 & 1978 & PS & Oil \\
\hline Kharampur Zapadnoye & PT & 64.17 & 78.92 & 1987 & SI & Oil \\
\hline Kharasaveyskoye & YA & 71.15 & 67.12 & 1974 & PP & Gas \\
\hline \multicolumn{7}{|l|}{ Kharvutaskoye } \\
\hline (Kharvutinskoye) & NP & 67.29 & 74.18 & 1976 & PP & Oil \\
\hline khay-Yakhinskoye & PT & 66.27 & 77.67 & & SI & Oil \\
\hline Khokhlovskoye & OB & 60.90 & 76.25 & 1987 & SI & Oil \\
\hline Khokhryakovskoye & VA & 61.53 & 79.39 & 1972 & PS & Oil \\
\hline Khokhryakovskoye Severnoye & VA & 62.04 & 79.52 & 1976 & PS & Oil \\
\hline Kholmistoye & PT & 63.26 & 80.11 & 1988 & SI & Oil \\
\hline Kholmogoryskoye & OB & 62.94 & 74.35 & 1973 & PS & Oil \\
\hline Khorlorskoye & OB & 62.89 & 71.52 & 1993 & SI & Oil \\
\hline Khorlorskoye Verkhniy & OB & & & 1994 & SI & Oil \\
\hline Khulturskoye & UR & 60.48 & 64.10 & & SI & Oil \\
\hline Khulymskoye Yuzhnoye & $O B$ & 64.25 & 70.72 & 1986 & SI & Oil \\
\hline Khvoynoye & $O B$ & 60.12 & 77.24 & 1984 & PP & Oil \\
\hline Kinyaminskoye Yuzhnoye & $\mathrm{OB}$ & 60.37 & 74.92 & 1990 & SI & Oil \\
\hline Kinyaminskoye & OB & & & 1990 & $\mathrm{Si}$ & Oil \\
\hline Kislorskoye & FR & 63.65 & 66.55 & 1993 & SI & Oil \\
\hline Kiyevyeganskoye & PA & 60.11 & 80.84 & 1970 & $\mathrm{SI}$ & Oil \\
\hline Klyuchevskoye (Tomsk) & VA & 58.84 & 77.53 & 1968 & PP & Oil \\
\hline Kochevskoye Severnoye & OB & 62.68 & 73.43 & & PP & Oil \\
\hline Kochevskoye(Tevlin-Konitlor) & OB & 62.50 & 73.40 & 1979 & PS & Oil \\
\hline Kogolymskoye & OB & 62.44 & 73.79 & 1972 & PS & Oil \\
\hline Kogolymskoye Severnoye & $\mathrm{OB}$ & 62.74 & 73.86 & 1984 & SI & Oil \\
\hline Kogolymskoye Yuzhnoye & $\mathrm{OB}$ & 62.37 & 73.95 & 1972 & SI & Oil \\
\hline Kolikyeganskoye & VA & 61.34 & 79.16 & 1971 & DV & Oil \\
\hline Kolikyeganskoye Vostochnoye & VA & & & 1987 & SI & Oil \\
\hline Kolotuchnoye & VA & 58.68 & 77.50 & 1986 & SI & Oil \\
\hline Komar'inskoye & OB & 61.48 & 72.13 & 1971 & PS & Oil \\
\hline \multicolumn{7}{|l|}{ Komsomol' skoye } \\
\hline (Barsukovskoye) & NP & 64.44 & 75.98 & 1966 & PS & Gas \\
\hline Komsomolskoye Severnoye & NP & 64.73 & 75.35 & 1969 & PP & Gas \\
\hline Kondakovskoye (Tomsk) & VA & 60.37 & 78.74 & 1982 & SI & Oil \\
\hline Kondinskoye Vostochnaya & VA & & & 1991 & SI & Oil \\
\hline Konitlorskoye Severnoye & OB & 62.70 & 72.79 & 1986 & SI & Oil \\
\hline Konitlorskoye Vostochnoye & OB & 62.50 & 72.80 & 1990 & SI & Oil \\
\hline Konitlorskoye Yuzhnoye & OB & 62.15 & 72.83 & 1988 & SI & Oil \\
\hline Konitlorskoye Zapadnoye & OB & 62.26 & 72.54 & 1989 & SI & Oil \\
\hline Konitlorskoye(Tevlin-Konitlor) & OB & 62.50 & 72.80 & 1972 & SI & Oil \\
\hline Koshilsko-Vakhskoye & VA & 61.07 & 79.22 & 1987 & PS & Oil \\
\hline Kotukhtaskoye Zapadnoye & OB & 62.64 & 75.47 & 1981 & SI & Oil \\
\hline Krapivinskoye & KA & 58.03 & 75.68 & 1969 & SI & Oil \\
\hline Krapivinskoye Severnoye & $\mathrm{KA}$ & 58.07 & 75.74 & 1986 & SI & Oil \\
\hline Krapivinskoye Vostochnoye & KA & 58.09 & 75.73 & 1986 & SI & Oil \\
\hline
\end{tabular}


Table 1D. Basic Field Information, West Siberian Basin (Sorted Alphabetically by Field Name) (Continued)

\begin{tabular}{|c|c|c|c|c|c|c|}
\hline Field Name & Reçion & $\begin{array}{l}\text { North } \\
\text { Latitude } \\
\text { (degrees) }\end{array}$ & $\begin{array}{l}\text { East } \\
\text { Latitude } \\
\text { (degrees) }\end{array}$ & $\begin{array}{c}\text { Discovery } \\
\text { Date }\end{array}$ & $\begin{array}{l}\text { Producing } \\
\text { Status }\end{array}$ & $\begin{array}{l}\text { Primary } \\
\text { Product }\end{array}$ \\
\hline Krasnoleninskoye & $F \mid \mathbf{Z}$ & 61.70 & 66.77 & 1962 & PS & Oil \\
\hline Krasnoyarskoye Zapadnoye & V.A & 59.08 & 77.83 & 1965 & SI & Oil \\
\hline Kraynyeyeskoye & NP & 63.75 & 74.33 & 1982 & PS & Oil \\
\hline Kruzenshternskoye Yuzhnoye & YA & 70.60 & 67.20 & 1980 & SI & Gas \\
\hline Kudrinskoye & $\mathrm{OB}$ & 60.83 & 72.50 & 1990 & & Oil \\
\hline Kul'yeganskoye (Tyumen) & OB & 59.99 & 76.17 & 1986 & SI & Oil \\
\hline Kulginskoye & $\mathrm{U}<\mathrm{N}$ & & & 1992 & SI & Oil \\
\hline Kulyeganskoye(Tomsk) & Vit & 60.01 & 77.76 & 1988 & SI & Oil \\
\hline Kurraganskoye & 03 & 61.72 & 75.95 & 1980 & SI & Oil \\
\hline Kurraganskoye Yuzhnoye & OB & 61.66 & 75.92 & 1988 & SI & Oil \\
\hline Kustovoyeskoye Yuzhnoye & $\mathrm{OB}$ & 62.03 & 74.33 & 1986 & $\mathrm{SI}$ & Oil \\
\hline Kvartovoye & $\mathrm{Ol3}$ & 60.05 & 77.08 & 1974 & $\mathrm{SI}$ & Oil \\
\hline Kynskoye & $\mathrm{P}^{\top}$ & 65.15 & 80.58 & 1982 & SI & Oil \\
\hline Kysomskoye & $\mathrm{Ol} 3$ & 61.50 & 77.17 & 1987 & PP & Oil \\
\hline Larkinskoye & Ol3 & 62.13 & 72.42 & 1986 & SI & Oil \\
\hline Larlominskoye Yuzhnoye & $\mathrm{KA}$ & 58.98 & 75.30 & & SI & Oil \\
\hline Larlomkinskoye & $\mathrm{KA}$ & 59.08 & 75.31 & 1971 & SI & Oil \\
\hline \multicolumn{7}{|l|}{ Lasyeganskoye } \\
\hline (Pokachev-Ur'yev) & $\mathrm{Ol} 3$ & 61.50 & 75.00 & 1979 & PS & Oil \\
\hline Lazarevskoye & UFR & 61.06 & 64.93 & 1984 & PS & Oil \\
\hline Lebyazhyeskove & $\mathrm{FFI}$ & 61.98 & 66.91 & 1981 & SI & Oil \\
\hline \multicolumn{7}{|l|}{ Ledovoye Severnoye } \\
\hline (Tomsk) & OB3 & 59.62 & 76.77 & & $\mathrm{SI}$ & Oil \\
\hline Ledovoye (Tomsk) & OE3 & 59.54 & 76.69 & 1972 & SI & Oil \\
\hline Ledyanoye & OE3 & 59.66 & 76.15 & 1987 & SI & Oil \\
\hline Lem'inskoye Vostochnoye & UFI & 61.00 & 63.83 & 1964 & SI & Oil \\
\hline Lem'inskoye Zapadnoye & UFi & 61.00 & 63.66 & 1965 & SI & Oil \\
\hline Leminskoye (Lemya) & UFI & 60.88 & 63.91 & 1964 & DV & Oil \\
\hline \multicolumn{7}{|l|}{ Lempinskoye Zapadnoye } \\
\hline (Pravdinsk-Salym) & OE & 60.83 & 71.42 & 1964 & SI & Oil \\
\hline Leningradskoye & YA & 65.50 & 72.20 & 1990 & SI & Gas \\
\hline Leninskoye(Karabashskoye) & UFi & 58.67 & 66.33 & 1964 & PP & Gas \\
\hline Lenzitskoye & NF & 66.32 & 72.87 & 1984 & Sl & Oil \\
\hline Limbayakhaskove & PT & 67.20 & 80.40 & 1991 & SI & Oil \\
\hline Lineynoye & PA & 60.57 & 80.50 & 1972 & $\mathrm{SI}$ & Oil \\
\hline Lokosovoye & OE & 61.20 & 74.91 & 1963 & PS & Oil \\
\hline Lomovoye & VA & 59.28 & 77.04 & 1970 & PP & Oil \\
\hline Lontyn'yakhskoye & KA & 58.88 & 76.00 & 1964 & PP & Oil \\
\hline Lopukhovskoye & UF & 60.90 & 63.55 & & UKN & Oil \\
\hline Lorbinskoye & FR & 61.52 & 67.83 & 1966 & PS & Oil \\
\hline Loryeganskoye & OE & 61.44 & 77.04 & 1980 & PS & Oil \\
\hline Losevove & $\mathrm{OE}$ & 62.84 & 71.85 & 1987 & SI & Oil \\
\hline Lovinskoye & UR & 61.30 & 65.19 & 1982 & PS & Oil \\
\hline Lovinskoye Zapadnoye & UR & 61.25 & 65.00 & 1982 & SI & Oil \\
\hline Lower Tabaganskove & $\mathrm{KA}$ & 57.30 & 79.00 & 1985 & $\mathrm{SI}$ & Oil \\
\hline Luginetskoye & VA & 58.25 & 78.87 & 1967 & PP & Gas \\
\hline Luginetskoye Zapadnoye & $\mathrm{OB}$ & 58.20 & 78.88 & 1990 & SI & Oil \\
\hline Lyantorskove (Taybinskoye) & $O B$ & 61.54 & 72.11 & 1966 & PS & Oil \\
\hline Lykhminskoye & $\mathrm{FR}$ & 63.25 & 65.82 & 1982 & SI & Oil \\
\hline Maksimkinskove & UKN & & & 1992 & SI & Oil \\
\hline Malo Kolikyeganskoye & VA & & & 1987 & SI & Oil \\
\hline
\end{tabular}


Table 1D. Basic Field Information, West Siberian Basin (Sorted Alphabetically by Field Name) (Continued)

\begin{tabular}{|c|c|c|c|c|c|c|}
\hline Field Name & Region & $\begin{array}{l}\text { North } \\
\text { Latitude } \\
\text { (degrees) }\end{array}$ & $\begin{array}{l}\text { East } \\
\text { Latitude } \\
\text { (degrees) }\end{array}$ & $\begin{array}{c}\text { Discovery } \\
\text { Date }\end{array}$ & $\begin{array}{c}\text { Producing } \\
\text { Status } \\
\end{array}$ & $\begin{array}{l}\text { Primary } \\
\text { Product }\end{array}$ \\
\hline Malo-Aganskove Yuzhnove & OB & 61.45 & 76.02 & 1980 & PP & Oil \\
\hline Malo-Perevalnoye & $\mathrm{OB}$ & 63.25 & 72.62 & 1991 & SI & Oil \\
\hline Malo-Tolumskoye & UR & 60.51 & 65.29 & 1978 & PP & Oil \\
\hline Malobalykskoye & OB & 60.48 & 72.25 & 1966 & PS & Oil \\
\hline Malochernogorskoye & OB & 61.49 & 77.20 & 1969 & PS & Oil \\
\hline Malodanilovskoye & UR & & & 1966 & SI & Oil \\
\hline Maloichskoye & $\mathrm{KA}$ & 56.82 & 78.48 & 1974 & PP & Oil \\
\hline Maloklyuchevoye & $O B$ & 61.59 & 75.83 & 1983 & $\mathrm{SI}$ & Oil \\
\hline Malokustovoye & $\mathrm{OB}$ & 62.07 & 74.48 & 1986 & $\mathrm{SI}$ & Oil \\
\hline Maloledyanoye & $O B$ & 59.60 & 76.17 & 1989 & SI & Oil \\
\hline Malonovogodneye & NP & 61.18 & 77.08 & 1980 & SI & Oil \\
\hline Malopokachevskoye & $\mathrm{OB}$ & 61.81 & 75.19 & 1973 & SI & Oil \\
\hline Malopotanayskoye & UR & 61.36 & 65.75 & 1989 & SI & Oil \\
\hline Malopriobskoye & FR & & & & Oil & \\
\hline Malopyakutaskoye & $O B$ & 63.70 & 73.28 & 1986 & $\mathrm{SI}$ & Oil \\
\hline Malorechenskoye & $\mathrm{OB}$ & 60.52 & 77.24 & 1965 & PS & Oil \\
\hline Malovar'yeganskoye & NP & 62.20 & 77.02 & 1986 & $\mathrm{SI}$ & Oil \\
\hline Malovat'yeganskoye & OB & 62.15 & 75.32 & 1984 & PP & Oil \\
\hline Maloveselovskoye & $\mathrm{KA}$ & 56.42 & 77.98 & 1964 & SI & Oil \\
\hline Maloyagunskoye & $O B$ & 62.30 & 74.30 & & SI & Oil \\
\hline \multicolumn{7}{|l|}{ Maloyamalskoye } \\
\hline (Lesser Yamal) & YA & 68.32 & 71.60 & 1975 & DV & Gas \\
\hline Maloyugan Severnoye & OB & 60.20 & 75.10 & & $\mathrm{SI}$ & Oil \\
\hline Maloyuganskoye & $\mathrm{OB}$ & 60.19 & 75.18 & 1975 & SI & Oil \\
\hline Malyginskoye & YA & 72.20 & 70.44 & 1979 & PP & Gas \\
\hline \multicolumn{7}{|l|}{ Mamontovskoye } \\
\hline (Ust-Balyk) & $O B$ & 61.09 & 72.57 & 1965 & PS & Oil \\
\hline Mangazeyskoye & PT & 66.80 & 82.67 & 1987 & SI & Oil \\
\hline Maslikhovskoye & OB & 61.70 & 71.64 & 1985 & PS & Oil \\
\hline Matyushkinskoye & $\mathrm{OB}$ & 59.89 & 76.98 & 1969 & SI & Oil \\
\hline Mayskoye & $O B$ & 60.41 & 72.80 & 1978 & PS & Oil \\
\hline Medvezhyeskoye & NP & 66.23 & 74.00 & 1966 & PP & Gas \\
\hline Megionskoye & $\mathrm{OB}$ & 61.13 & 76.00 & 1964 & PS & Oil \\
\hline Meretayakhaskoye & NP & 64.61 & 74.59 & 1986 & SI & Oil \\
\hline Messoyakhaskoye Vostochnay & yа PT & 68.60 & 80.12 & 1989 & SI & Oil \\
\hline Messoyakhaskoye Yuzhnaya & GY & 68.06 & 79.40 & 1986 & SI & Gas \\
\hline Messoyakhaskoye Zapadnaya & GY & 68.50 & 79.12 & 1982 & SI & Oil \\
\hline \multicolumn{7}{|l|}{$\begin{array}{l}\text { Messoyakhskoye } \\
\text { (Norilisk City1970) }\end{array}$} \\
\hline (Yenisey-Khatanga) & GY & 69.20 & 82.40 & 1967 & PP & Gas \\
\hline Mezhovskoye & KA & 56.54 & 77.86 & 1964 & SI & Oil \\
\hline Mezhovskoye Vostochnoye & $\mathrm{KA}$ & 56.59 & 78.12 & 1966 & SI & Oil \\
\hline Minchimkaskoye & $O B$ & 61.88 & 72.87 & 1969 & SI & Oil \\
\hline Minchimkaskoye Severnaya & $O B$ & 61.92 & 72.67 & 1969 & SI & Oil \\
\hline Minkhovskoye & GY & 69.37 & 76.02 & 1989 & SI & Gas \\
\hline Minkhovskoye Vostochnoye & GY & 69.37 & 76.02 & 1991 & SI & Gas \\
\hline Mirnoye & VA & 57.67 & 79.50 & 1982 & $\mathrm{SI}$ & Oil \\
\hline Mogutlorskoye & $\mathrm{OB}$ & 62.03 & 75.82 & 1987 & $\mathrm{SI}$ & Oil \\
\hline Mogutlorskoye Zapadnoye & $\mathrm{OB}$ & 62.02 & 75.65 & 1986 & PP & Oil \\
\hline Moiseyevskoye & KA & 58.19 & 76.06 & 1970 & SI & Oil \\
\hline Moiseyevskoye Zapadnoye & $\mathrm{KA}$ & 58.20 & 75.83 & 1992 & SI & Oil \\
\hline
\end{tabular}


Table 1D. Basic Field Information, West Siberian Basin (Sorted Alphabetically by Field Name) (Continued)

\begin{tabular}{|c|c|c|c|c|c|c|}
\hline Field Name & Region & $\begin{array}{l}\text { North } \\
\text { Latitude } \\
\text { (degrees) }\end{array}$ & $\begin{array}{c}\text { East } \\
\text { Latitude } \\
\text { (degrees) }\end{array}$ & $\begin{array}{c}\text { Discovery } \\
\text { Date } \\
\end{array}$ & $\begin{array}{c}\text { Producing } \\
\text { Status } \\
\end{array}$ & $\begin{array}{l}\text { Primary } \\
\text { Product }\end{array}$ \\
\hline Mokhovoye Vostochnoye & $\mathrm{OB}$ & 61.88 & 74.34 & 1973 & SI & Oil \\
\hline Mokhtikovskoye & $\mathrm{Ol3}$ & 60.44 & 76.58 & 1988 & SI & Oil \\
\hline Mortym'yaskoye Severnoye & UF3 & 60.40 & 64.80 & 1977 & PP & Oil \\
\hline Mortym'yaskoye Yuzhnoye & UF3 & 60.40 & 64.80 & 1962 & PP & Oil \\
\hline Mortym'yaskoye Zapadnoye 1 & UF? & 60.40 & 64.80 & 1962 & PP & Oil \\
\hline Mortym'yaskoye Zapadnoye 2 & UFY & 60.40 & 64.80 & 1962 & PP & Oil \\
\hline Mortym'yaskoye Zapadnoye 3 & UFY & 60.40 & 64.80 & 1962 & PP & Oil \\
\hline Multanovoskoye & $\mathrm{K} A_{\mathrm{i}}$ & 60.08 & 73.55 & 1971 & DV & Oil \\
\hline Mulym'yaskoye & UFi & 60.24 & 64.42 & 1960 & PS & Oil \\
\hline Mulymyaskoye Srednyaya & UFI & 60.62 & 64.77 & 1963 & SI & Oil \\
\hline Mulymyaskoye Zapadnoye & UFi & 60.24 & 64.42 & 1960 & PP & Oil \\
\hline Muravlenkoskoye & NF' & 63.99 & 74.95 & 1978 & PS & Oil \\
\hline Muryaunskoye & UK.N & & & & SI & Oil \\
\hline Mykhlorskoye & VA. & 61.31 & 77.53 & 1985 & SI & Oil \\
\hline Mykhpayskoye(Samotlor) & OES & 61.20 & 76.60 & 1961 & PS & Oil \\
\hline Myldzhinskoye & VA & 58.74 & 78.44 & 1964 & DV & Gas \\
\hline Myldzhinskoye Yuzhnoye & VA & 58.51 & 78.15 & 1967 & SI & Oil \\
\hline Nadymskoye & NF & 65.50 & 72.97 & 1972 & SI & Gas \\
\hline Nakhodkaskoye & NF & 68.02 & 78.17 & 1974 & SI & Gas \\
\hline Nalim'yeskoye & KA & 57.84 & 76.74 & 1987 & SI & Oil \\
\hline Nazinskoye Yuzhnoye & VA & 60.07 & 78.73 & 1961 & SI & Oil \\
\hline Nazymskoye & FR & 62.48 & 67.89 & 1988 & SI & Oil \\
\hline Neponyatnoye & NP & 66.80 & 77.77 & 1986 & SI & Oil \\
\hline Nerstinskoye & YA & 70.20 & 68.50 & & SI & Gas \\
\hline Ney-To (Neytinskoye) & YA & 70.06 & 70.16 & 1975 & DV & Gas \\
\hline Nezhdannoye & OE & 60.43 & 76.87 & 1981 & SI & Oil \\
\hline Nikol'skoye (Tomsk) & VA & 59.97 & 79.05 & 1971 & SI & Oil \\
\hline Nikol'skoye (Tyumen) & VA & 61.45 & 77.58 & 1985 & PS & Oil \\
\hline Nivagalskoye(Pokachev-Ur'yev) & v) $\mathrm{OB}$ & 61.66 & 74.80 & 1968 & PS & Oil \\
\hline \multicolumn{7}{|c|}{ Nizhne Khetskoye } \\
\hline (Yenisey-Khatanga) & GY & 69.50 & 84.50 & 1966 & ABND & Gas \\
\hline Nizhne Tabaganskoye & KA & 58.25 & 79.17 & 1973 & SI & Oll \\
\hline Nizhne-Shapshinskoye & OB & 60.50 & 70.33 & & SI & Oil. \\
\hline Nizhne-Sortymskoye & $\mathrm{OB}$ & 62.48 & 71.68 & 1974 & PS & Oil \\
\hline Nizhne-Tobolyanskoye & VA & 58.42 & 78.83 & 1975 & SI & Oil \\
\hline Nizhnevartovskoye & $\mathrm{OB}$ & 60.80 & 77.10 & 1965 & PP & Oil \\
\hline Nizhniy Keumskoye & KA & 59.59 & 71.36 & & SI & Oil \\
\hline Nong'yeganskoye & $\mathrm{OB}$ & 61.89 & 74.86 & 1974 & PS & Oil \\
\hline Nong'yeganskoye Vostochnoye & je $\mathrm{OB}$ & 61.84 & 75.01 & 1974 & SI & Oil \\
\hline Novoaganskoye & NP & 61.83 & 78.13 & 1985 & SI & Oil \\
\hline Novochaselskoye & PT & 65.42 & 80.17 & 1989 & SI & Oil \\
\hline Novogodneye & NP & 63.49 & 76.92 & 1976 & PS & Oil \\
\hline Novogodneye Zapadnoye & NP & 63.47 & 76.41 & 1987 & Sl & Oil \\
\hline Novomolodezhnoye & NP & 61.60 & 78.08 & 1977 & PS & Oil \\
\hline Novopokurskoye & $O B$ & 60.75 & 74.50 & 1981 & PS & Oil \\
\hline Novoportovskoye & YA & 67.88 & 72.43 & 1964 & DV & Gas \\
\hline Novopurpeyskoye & NP & 64.20 & 75.43 & 1983 & PS & Oil \\
\hline Novoyendyrskoye & FR & 61.85 & 67.87 & 1977 & SI & Oil \\
\hline Novyy-Tutymskoye & KA & 58.80 & 74.20 & 1988 & SI & Oil \\
\hline Noyabr'skoye Zapadnoye & $O B$ & 63.39 & 75.01 & 1987 & PS & Oil \\
\hline Nulin-Turskoye & UR & 62.95 & 64.22 & 1961 & SI & Gas \\
\hline
\end{tabular}


Table 1D. Basic Field Information, West Siberian Basin (Sorted Alphabetically by Field Name) (Continued)

\begin{tabular}{|c|c|c|c|c|c|c|}
\hline Field Name & Region & $\begin{array}{l}\text { North } \\
\text { Latitude } \\
\text { (degrees) } \\
\end{array}$ & $\begin{array}{l}\text { East } \\
\text { Latitude } \\
\text { (degrees) }\end{array}$ & $\begin{array}{c}\text { Discovery } \\
\text { Date }\end{array}$ & $\begin{array}{l}\text { Producing } \\
\text { Status } \\
\end{array}$ & $\begin{array}{l}\text { Primary } \\
\text { Product }\end{array}$ \\
\hline Nurminskoye & YA & 68.77 & 71.77 & 1970 & SI & Gas \\
\hline Nydinskoye & NP & & & 1981 & SI & Gas \\
\hline Ob River Area & OB & & & 1982 & SI & Oil \\
\hline Okhanskoye & UR & 61.03 & 65.68 & 1967 & SI & Oil \\
\hline Okhteurskoye Vostochnoye & VA & & & 1994 & SI & Oil \\
\hline Okhteurskoye Yuzhnny & VA & 60.76 & 78.50 & 1990 & SI & Oil \\
\hline Ol'khovskoye (Tyumen) & FR & 63.20 & 67.86 & 1986 & SI & Oil \\
\hline Olen'yeskoye & $\mathrm{KA}$ & 59.36 & 76.34 & 1967 & PS & Oil \\
\hline Olen'yeskoye Severnoye & $\mathrm{KA}$ & 59.40 & 76.40 & 1989 & PP & Oil \\
\hline Ombinskoye & $\mathrm{OB}$ & 61.05 & 72.83 & 1989 & PP & Oil \\
\hline Ontokhskoye & FR & 60.81 & 66.15 & 1989 & SI & Oil \\
\hline Orekhov Severnoye & $\mathrm{OB}$ & 61.00 & 76.23 & & SI & Oil \\
\hline Orekhovoskoye & $\mathrm{OB}$ & 60.82 & 75.70 & 1976 & SI & Oil \\
\hline Osomkinskoye Zapadnoye & OB & 61.00 & 73.55 & & SI & Oil \\
\hline Ostaninskoye & VA & 57.70 & 79.37 & 1970 & DV & Gas \\
\hline Ostaninskoye Severnoye & VA & 57.91 & 79.29 & 1977 & $\mathrm{SI}$ & Oil \\
\hline Ostaninskoye Zapadnoye & VA & 57.73 & 79.04 & 1972 & PS & Oil \\
\hline Ostrovnoye & OB & 60.93 & 75.18 & 1980 & SI & Oil \\
\hline Ostrovnoye Severnoye & $\mathrm{OB}$ & 61.01 & 74.84 & 1978 & PP & Oil \\
\hline Ostrovnoye Yuzhnoye & OB & 60.75 & 74.92 & 1989 & si & Oil \\
\hline Otdelnoye & OB & 62.93 & 74.86 & 1985 & SI & Oil \\
\hline Ozernoye (Tomsk) & $\mathrm{KA}$ & 59.20 & 76.47 & 1970 & PS & Oil \\
\hline \multicolumn{7}{|l|}{ Ozernoye } \\
\hline (Vostochnoye \& Zapadnoye) & UR & 62.25 & 63.50 & 1963 & DV & Gas \\
\hline Pal'nikovskoye & $\mathrm{OB}$ & 64.63 & 72.18 & 1992 & si & Oil \\
\hline Palyanovskoye & FR & 61.75 & 65.92 & 1972 & PP & Oil \\
\hline Pangodyskoye & NP & 65.56 & 74.53 & 1979 & SI & Gas \\
\hline Parusovoye & GY & 68.44 & 74.67 & 1985 & PP & Oil \\
\hline Paul-Tur & UR & 63.09 & 64.16 & 1960 & SI & Gas \\
\hline Pavlovskoye (Tomsk) & KA & 58.50 & 75.78 & 1989 & SI & Oil \\
\hline Paysyataskoye & NP & 64.30 & 73.90 & 1988 & SI & Oil \\
\hline Paytykhskoye & FR & 61.26 & 65.37 & 1987 & SI & Oil \\
\hline \multicolumn{7}{|l|}{ Pelyatkinskoye } \\
\hline (Yenisey-Khatanga) & GY & 69.60 & 81.80 & 1977 & DV & Gas \\
\hline Perekatnoye & PT & 67.74 & 78.69 & 1988 & SI & Gas \\
\hline Pereval'noye Vostochnoye & OB & 63.26 & 72.63 & 1990 & SI & Oil \\
\hline Perevalnoye Yuzhnoye & OB & & & 1991 & SI & Oil \\
\hline Permyakovskoyeskoye & VA & 61.34 & 79.55 & 1972 & PS & Oil \\
\hline Pervomayskoye (Tomsk) & KA & 59.05 & 75.96 & 1969 & PS & Oil \\
\hline Peschanoye & FR & 62.23 & 65.95 & 1987 & $\mathrm{SI}$ & Oil \\
\hline Pestsovoye Zapadnoye & NP & 66.91 & 74.73 & 1985 & PP & Gas \\
\hline Petelinskoye & OB & 60.55 & 71.92 & 1982 & PS & Oil \\
\hline Piltanskoye & $\mathrm{OB}$ & 61.68 & 73.15 & 1985 & PP & Oil \\
\hline Pindzhinskoye & VA & 57.64 & 79.68 & 1985 & Si & Oil \\
\hline Pionerskoye & VA & 58.97 & 77.27 & & SI & Oil \\
\hline Pogranichnoye (Tyumen) & OB & 62.91 & 75.19 & 1982 & PS & Oil \\
\hline $\begin{array}{l}\text { Pokachevsko-Ur'yevskoye } \\
\text { (Akhskoye, Lasyeganskoye, } \\
\text { Nivagalskoye, Potochnoye, } \\
\text { Potochnoye Severnoye, } \\
\text { Pokachevskoye Yuzhnoye, }\end{array}$ & & & & & & \\
\hline
\end{tabular}


Table 1D. Basic Field Informaticin, West Siberian Basin (Sorted Alphabetically by Field Name) (Continued)

\begin{tabular}{|c|c|c|c|c|c|c|}
\hline Field Name & Region & $\begin{array}{l}\text { North } \\
\text { Latitude } \\
\text { (degrees) }\end{array}$ & $\begin{array}{c}\text { East } \\
\text { Latitude } \\
\text { (degrees) }\end{array}$ & $\begin{array}{c}\text { Discovery } \\
\text { Date }\end{array}$ & $\begin{array}{c}\text { Producing } \\
\text { Status } \\
\end{array}$ & $\begin{array}{l}\text { Primary } \\
\text { Product }\end{array}$ \\
\hline Ur'yevskoye) & 0.3 & 61.73 & 75.23 & 1970 & PS & Oil \\
\hline Pokachevskoye Severnoye & & & & & & \\
\hline (Pokachev-Ur'yev) & $\mathrm{O} 3$ & 61.89 & 75.56 & 1980 & PP & Oil \\
\hline Pokachevskoye Vostochnoye & $\mathrm{O} 3$ & 61.85 & 75.90 & 1980 & SI & Oil \\
\hline (Pokachev-Ur'yev) & $\mathrm{O} 3$ & 61.64 & 75.33 & 1976 & PP & Oil \\
\hline Pokamasovskoye & $\mathrm{O} 13$ & 61.20 & 74.39 & 1972 & PS & Oil \\
\hline Pokamasovskoye Yuzhnoye & $\mathrm{O} 3$ & 61.07 & 74.50 & & $\mathrm{SI}$ & Oil \\
\hline Pokamasovskoye Zapadnoye & $\mathrm{O} 3$ & 61.32 & 74.40 & & SI & Oil \\
\hline Pokhromskoye & UR & 64.08 & 65.83 & 1960 & PP & Gas \\
\hline Pokurskoye Severskoye & $\mathrm{Ol3}$ & 61.20 & 75.50 & 1964 & PS & Oil \\
\hline Poludennoye (Tomsk) & VA & 60.08 & 78.25 & 1967 & PS & Oil \\
\hline Poludennoye (Tyumen) & $\mathrm{OB}$ & 60.54 & 76.64 & 1983 & PP & Oil \\
\hline Poludennoye Severnoye & $V A_{i}$ & & & 1992 & SI & Oil \\
\hline Polun'yakhskoye & $\mathrm{K} f_{\mathrm{i}}$ & 59.54 & 73.03 & 1990 & SI & Oil \\
\hline Pomaliyakhskoye Severnoye & OE3 & 64.08 & 74.25 & 1989 & $\mathrm{PP}$ & Oil \\
\hline Pon'zhevoye & $\mathrm{K} A$ & 57.92 & 76.52 & 1983 & SI & Oil \\
\hline Poselkovoye & $\mathrm{K} f_{1}$ & 58.56 & 76.47 & 1982 & SI & Oil \\
\hline Posnokortskoye & UNIK & & & & SI & Oil \\
\hline Potanayskoye & UFi & 61.17 & 65.62 & 1965 & SI & Oil \\
\hline Potanayskoye Severnoye & UFY & 61.22 & 65.60 & 1965 & SI & Oil \\
\hline Potanayskoye Vostochnoye & UFI & 61.17 & 65.62 & 1990 & SI & Oil \\
\hline Potanayskoye Yuzhnoye & UFI & 61.13 & 65.68 & 1966 & SI & Oil \\
\hline Potochnoye Severnoye & & & & & & \\
\hline (Poka-Ury) & OE & & & 1979 & SI & Oil \\
\hline Potochnoye(Poka-Ury) & OE & & & 1974 & SI & Oil \\
\hline Pottymskoye & FF & 61.22 & 66.99 & 1988 & SI & Oil \\
\hline Povkhovskoye & OE & 62.36 & 75.81 & 1972 & PS & Oil \\
\hline Povkhovskoye Severnoye & $\mathrm{OE}_{i}$ & 62.80 & 76.20 & & SI & Oil \\
\hline Povkhovskoye Yuzhnoye & OE & 62.39 & 76.19 & 1972 & SI & Oil \\
\hline Pravdinsk-Salymskoye & OE & 60.94 & 71.78 & 1964 & PS & Oil \\
\hline Pridorozhnoye Vostochnoye & OE & 62.10 & 74.67 & & SI & Oil \\
\hline Priobskoye & FR & 61.13 & 70.46 & 1982 & PS & Oil \\
\hline Priobskoye Severnoye & FR & 61.56 & 70.50 & 1988 & SI & Oil \\
\hline Priobskoye Zapadnoye & FR & 61.59 & 70.37 & 1988 & SI & Oil \\
\hline Prirakhtovskoye & FR & 57.36 & 72.21 & 1975 & SI & Oil \\
\hline Prisklonovoye & NP & 65.18 & 76.97 & & & Oil \\
\hline Promezhutochnoye & OE & 61.33 & 71.50 & & SI & Oil \\
\hline Protochnoye & VA & 60.65 & 78.33 & 1978 & SI & Oil \\
\hline Protochnoye Severnoye & VA & 60.63 & 78.20 & 1979 & SI & Oil \\
\hline Protochnoye Yuzhnoye & VA & 60.52 & 78.17 & 1978 & SI & Oil \\
\hline Puglalymskoye & VA & 58.89 & 77.73 & 1971 & SI & Oil \\
\hline Pulpuyakhskoye & NP & 63.83 & 73.67 & 1977 & SI & Oil \\
\hline Punga (Punginskoye) & UR & 62.76 & 64.44 & 1961 & PP & Gas \\
\hline Purovskoye Severnoye & PT & 66.54 & 78.33 & 1986 & Sl & Gas \\
\hline Purpeyskoye Yuzhnoye & NP & 64.17 & 74.28 & 1984 & SI & Oil \\
\hline Purpeyskoye Zapadnoye & NP & 64.59 & 75.54 & 1987 & PP & Oil \\
\hline Pyakutaskoye & $\mathrm{OB}$ & 63.74 & 73.10 & 1987 & SI & Oil \\
\hline Pyakuta Vostochnoye & $O B$ & 63.58 & 74.14 & 1982 & DV & Oil \\
\hline Pyakyakhinskoye & PY & 67.84 & 80.13 & 1989 & SI & Gas \\
\hline Pyamaliyakhskoye Severnoye & NP & 64.00 & 74.20 & 1982 & PS & Oil \\
\hline
\end{tabular}


Table 1D. Basic Field Information, West Siberian Basin (Sorted Alphabetically by Field Name) (Continued)

\begin{tabular}{|c|c|c|c|c|c|c|}
\hline Field Name & Region & $\begin{array}{l}\text { North } \\
\text { Latitude } \\
\text { (degrees) }\end{array}$ & $\begin{array}{c}\text { East } \\
\text { Latitude } \\
\text { (degrees) }\end{array}$ & $\begin{array}{l}\text { Discovery } \\
\text { Date }\end{array}$ & $\begin{array}{l}\text { Producing } \\
\text { Status }\end{array}$ & $\begin{array}{l}\text { Primary } \\
\text { Product }\end{array}$ \\
\hline Pylinskoye & $\mathrm{OB}$ & 61.05 & 77.54 & 1980 & PP & Oil \\
\hline Pylinskoye Zapadnoye & $O B$ & 61.05 & 77.50 & 1991 & SI & Oil \\
\hline Pyreynoye & NP & 65.62 & 77.69 & 1976 & DV & Gas \\
\hline Pyreynoye Yuzhnoye & NP & 65.62 & 77.69 & 1980 & SI & Oil \\
\hline Rakitinskoye & KA & 56.96 & 78.96 & 1971 & SI & Oil \\
\hline Ravenskoye & $\mathrm{OB}$ & 61.90 & 74.17 & 1981 & SI & Oil \\
\hline Ravninnoye & PT & 63.33 & 79.52 & 1987 & SI & Oil \\
\hline Rechnoye & VA & 58.39 & 77.92 & 1981 & $\mathrm{SI}$ & Gas \\
\hline Rodnikovoye & $\mathrm{OB}$ & 61.73 & 74.25 & 1988 & PP & Oil \\
\hline Rogozhnikovskoye & $\mathrm{FR}$ & 62.21 & 67.29 & 1988 & Si & Oil \\
\hline Rogozhnikovskoye Severnoye & FR & 62.30 & 67.20 & 1990 & SI & Oil \\
\hline Rogozhnikovskoye Yuzhnoye & FR & 62.10 & 67.50 & 1990 & SI & Oil \\
\hline Rogozhnikovskoye Zapadnoye & FR & 62.20 & 67.20 & & SI & Oil \\
\hline Romanovskoye & $\mathrm{OB}$ & 63.80 & 73.89 & 1987 & $\mathrm{SI}$ & Oil \\
\hline Roslavlskoye & $O B$ & 62.03 & 76.48 & 1988 & DV & Oil \\
\hline Rostovtsevskoye & YA & 68.43 & 72.40 & 1986 & DV & Gas \\
\hline Rubinovoye & OB & 61.13 & 76.28 & 1982 & PP & Oil \\
\hline Ruch'yevskoye & NP & 63.30 & 78.12 & 1987 & SI & Oil \\
\hline Ruf'yeganskoye & OB & 61.30 & 77.59 & 1982 & PP & Oil \\
\hline Rusanovskoye & YA & 73.40 & 65.50 & 1989 & SI & Gas \\
\hline Russkinskoye(Tevlin-Konitlor) & OB & & & 1982 & $\mathrm{Sl}$ & Oil \\
\hline Russkorechenskoye & PT & 67.14 & 81.82 & 1985 & SI & Oil \\
\hline Russkoye & PT & 66.75 & 80.44 & 1968 & DV & Oil \\
\hline Russkoye Yuzhnoye & PT & 65.93 & 80.38 & 1969 & DV & Gas \\
\hline Ryamnoye & OB & 60.91 & 76.75 & 1989 & DV & Oil \\
\hline Rybalnoye & VA & 58.18 & 79.83 & 1988 & SI & Oil \\
\hline Sakhalinskoye (Tyumen) & OB & 61.41 & 71.03 & 1983 & $\mathrm{SI}$ & Oil \\
\hline Sakhalinskoye Vostochnoye & OB & 61.51 & 71.28 & 1984 & SI & Oil \\
\hline Salekaptskoye & PT & 67.50 & 78.30 & 1986 & SI & Oil \\
\hline Salymskoye & OB & 60.00 & 71.00 & 1965 & DV & Oil \\
\hline \multicolumn{7}{|l|}{ Salymskoye Central } \\
\hline (Srednesalym) & OB & 60.00 & 71.00 & 1967 & PS & Oil \\
\hline Salymskoye Severnny & $\mathrm{OB}$ & 60.00 & 71.00 & 1978 & PS & Oil \\
\hline Salymskoye Vostochnoye & $\mathrm{OB}$ & 60.20 & 71.18 & 1989 & SI & Oil \\
\hline Salymskoye Zapadnoye & $\mathrm{OB}$ & 60.31 & 70.93 & 1987 & SI & Oil \\
\hline \multicolumn{7}{|l|}{ Samburgskoye Yuzhnoye } \\
\hline (Urengoy) & NP & 66.81 & 77.37 & 1979 & SI & Oil \\
\hline Samburgskoye (Urengoy) & NP & 66.81 & 77.37 & 1975 & DV & Oil \\
\hline \multicolumn{7}{|l|}{$\begin{array}{l}\text { Samotlorskoye (Vata, Megion, } \\
\text { Pokur Sev., Mykhpay, }\end{array}$} \\
\hline Orekhovo Sev.) & OB & 60.95 & 76.37 & 1961 & PS & Oil \\
\hline Sandibinskoye & NP & 66.76 & 73.20 & 1982 & PP & Oil \\
\hline Saporkinskoye & OB & 61.72 & 72.18 & 1982 & SI & Oil \\
\hline Sardakovskoye Yuzhnoye & OB & 62.18 & 76.19 & 1989 & SI & Oil \\
\hline Savuyskoye & OB & 61.88 & 73.78 & 1971 & PS & Oil \\
\hline Saygataskoye & OB & 61.27 & 72.89 & 1966 & PS & Oil \\
\hline Selimkhanovskoye & VA & 57.87 & 80.18 & 1981 & SI & Oil \\
\hline Selivonikoye & NP & 62.73 & 76.56 & 1988 & SI & Oil \\
\hline Seliyarovskoye & FR & 61.50 & 70.17 & & SI & Oil \\
\hline Seliyarovskoye Severnoye & FR & 61.81 & 69.49 & 1988 & SI & Oil \\
\hline Semakovskoye-Anderpayuta & GY & 68.90 & 75.53 & 1971 & SI & Gas \\
\hline
\end{tabular}


Table 1D. Basic Field Information, West Siberian Basin (Sorted Alphabetically by Field Name) (Continued)

\begin{tabular}{|c|c|c|c|c|c|c|}
\hline Field Name & Region & $\begin{array}{l}\text { North } \\
\text { Latitude } \\
\text { (degrees) }\end{array}$ & $\begin{array}{c}\text { East } \\
\text { Latitude } \\
\text { (degrees) }\end{array}$ & $\begin{array}{c}\text { Discovery } \\
\text { Date }\end{array}$ & $\begin{array}{c}\text { Producing } \\
\text { Status } \\
\end{array}$ & $\begin{array}{l}\text { Primary } \\
\text { Product }\end{array}$ \\
\hline Semividovskoye Vostochnoye & UR & 60.70 & 65.19 & 1967 & PS & Oil \\
\hline Severnoye & VA & 60.76 & 78.50 & 1965 & PS & Oil \\
\hline Seyakhinskoye Zapadnoye & YA & 70.85 & 70.86 & 1989 & SI & Gas \\
\hline Shapshinskoye & $\mathrm{OB}$ & 60.40 & 70.30 & 1981 & DV & Oil \\
\hline Shchuch'ye & OB & 61.79 & 76.88 & 1986 & SI & Oil \\
\hline Sheburskoye Vostochnoye & FR & 60.32 & 66.98 & 1990 & SI & Oil \\
\hline Shinginskoye & VA & 58.31 & 78.49 & 1971 & SI & Oil \\
\hline Shirokovskoye & $\mathrm{OB}$ & 61.39 & 74.05 & 1977 & DV & Oil \\
\hline Shirotnoye & KA & 56.68 & 80.78 & 1988 & SI & Oil \\
\hline Shtomovoye & UKIN & & & 1992 & SI & Gas \\
\hline Shukhtungortskoye Vostochnn & רy UR & 62.32 & 64.15 & 1963 & DV & Gas \\
\hline Shukhtungortskoye Zapadnoye & e UR & 62.45 & 64.00 & 1962 & DV & Gas \\
\hline Shukhtungortskoye & UR & 62.35 & 63.84 & 1962 & SI & Gas \\
\hline Shushminskoye & UR & 61.22 & 64.14 & 1984 & PS & Oil \\
\hline Shushminskoye Severnoye & UR & 61.25 & 64.32 & 1992 & SI & Oil \\
\hline Shushminskoye Yuzhnoye & UR & 61.22 & 64.14 & & SI & Oil \\
\hline Siktorskoye Severnoye & VA & 62.03 & 79.62 & 1976 & $\mathrm{SI}$ & Oil \\
\hline Sil'ginskoye Severnoye & PA & 58.94 & 80.12 & 1971 & SI & Gas \\
\hline Slavinskoye & UR & 60.75 & 64.50 & & SI & Oil \\
\hline Smolyanoye & KA & 57.35 & 78.41 & 1987 & SI & Oil \\
\hline Snezhnoye & PA & 58.97 & 79.78 & 1983 & SI & Oil \\
\hline Sobolinoye & PA & 58.46 & 79.53 & 1967 & PP & Oil \\
\hline Soimlorskoye Severnoye & $\mathrm{OB}$ & 63.34 & 73.83 & 1981 & DV & Oil \\
\hline Sokhtymskoye & $\mathrm{OB}$ & 62.50 & 72.35 & 1990 & SI & Oll \\
\hline \multicolumn{7}{|l|}{ Soleninskoye Severnoye } \\
\hline (Ust Yenisey) & GY & 69.24 & 81.48 & 1971 & PP & Gas \\
\hline \multicolumn{7}{|l|}{ Soleninskoye Yuzhno } \\
\hline (Ust Yenisey) & GY & 69.10 & 81.70 & 1969 & PP & Gas \\
\hline Soletskoye & GY & 69.72 & 75.21 & 1984 & $\mathrm{SI}$ & Gas \\
\hline Solkinskoye Zapadnoye & OB & 61.35 & 72.42 & 1976 & PP & Oil \\
\hline Solonovskoye & KA & 57.21 & 78.99 & 1986 & SI & Oil \\
\hline Sorominskoye & $\mathrm{OB}$ & 61.20 & 77.36 & 1971 & PS & Oil \\
\hline Sorominskoye Severnoye & $\mathrm{OB}$ & 61.23 & 77.42 & 1971 & SI & Oil \\
\hline Sorominskoye Zapadnoye & OB & 61.26 & 77.36 & 1971 & SI & Oil \\
\hline Sortymskoye & $\mathrm{OB}$ & 62.40 & 71.70 & 1992 & sI & Oll \\
\hline Sorymskoye & $\mathrm{OB}$ & & & 1982 & SI & Oil \\
\hline \multicolumn{7}{|l|}{ Sosnovomysskoye } \\
\hline (Krasnoleninskoye) & FR & 62.06 & 66.41 & 1975 & SI & Oil \\
\hline Sote-Yuganskoye Severnoye & FR & 62.30 & 64.50 & 1963 & PP & Gas \\
\hline Sote-Yuganskoye Yuzhnoye & FR & 62.19 & 64.55 & 1964 & PP & Gas \\
\hline Sote-Yuganskoye & FR & 62.25 & 64.50 & 1963 & SI & Gas \\
\hline Sovetskoye & $\mathrm{OB}$ & & & 1962 & DV & Oil \\
\hline Sporishevskoye & UKN & & & 1993 & sl & Oll \\
\hline Srede-Kharampurskove & PT & 64.10 & 73.63 & & SI & Oil \\
\hline Sredne Khulymskoye & $\mathrm{OB}$ & 64.55 & 71.29 & 1989 & SI & Oil \\
\hline Sredne-Imurskove & UKN & & & 1990 & SI & Oil \\
\hline Sredne-Iterskoye & $\mathrm{OB}$ & 63.50 & 74.67 & & si & Oil \\
\hline Sredne-Shapshinskoye & OB & 60.67 & 70.33 & & SI & Oil \\
\hline Sredne-Vasyuganskove & VA & 59.13 & 77.83 & 1965 & PP & Oil \\
\hline Sredne-Vatlorskoye & OB & 63.19 & 71.41 & 1988 & $\mathrm{SI}$ & Oil \\
\hline Sredneasomkinskove & $\mathrm{OB}$ & 61.00 & 73.00 & 1987 & PS & Oil \\
\hline
\end{tabular}


Table 1D. Basic Field Information, West Siberian Basin (Sorted Alphabetically by Field Name) (Continued)

\begin{tabular}{|c|c|c|c|c|c|c|}
\hline Field Name & Region & $\begin{array}{l}\text { North } \\
\text { Latitude } \\
\text { (degrees) }\end{array}$ & $\begin{array}{l}\text { East } \\
\text { Latitude } \\
\text { (degrees) }\end{array}$ & $\begin{array}{c}\text { Discovery } \\
\text { Date }\end{array}$ & $\begin{array}{l}\text { Producing } \\
\text { Status }\end{array}$ & $\begin{array}{l}\text { Primary } \\
\text { Product }\end{array}$ \\
\hline Srednebalykskoye & OB & 60.53 & 72.52 & 1965 & PS & Oil \\
\hline Srednechernogorskoye & OB & 61.41 & 76.78 & 1986 & SI & Oil \\
\hline Srednekondinskoye & UR & 60.88 & 63.83 & 1982 & SI & Oil \\
\hline Srednenazymskoye & $\mathrm{FR}$ & 61.95 & 68.34 & 1978 & SI & Oil \\
\hline Srednenyurol'skoye & VA & 58.92 & 77.87 & 1965 & SI & Oil \\
\hline Srednesil'ginskoye & PA & 58.87 & 80.14 & 1962 & SI & Gas \\
\hline Sredneteterevskoye & UR & 60.70 & 64.40 & 1970 & PP & Oil \\
\hline Sredneugutskoye & OB & 60.50 & 73.97 & 1988 & Si & Oil \\
\hline Sredneyamalskoye & YA & 69.06 & 71.16 & 1970 & DV & Gas \\
\hline Sredniy Lykhmskoye & FR & 63.51 & 66.44 & 1982 & SI & Oil \\
\hline Sredniy Nazymskoye & FR & 61.98 & 68.35 & 1978 & SI & Oil \\
\hline Stakhanovskoye & PT & 63.41 & 78.52 & 1988 & SI & Oil \\
\hline Stakhanovskoye Severnoye & PT & & & & SI & Oil \\
\hline Stavropolskoye & VA & & & 1990 & SI & Oil \\
\hline Stolbovoye & KA & 59.27 & 76.57 & 1986 & DV & Oil \\
\hline Strezhevoye & OB & 60.79 & 77.46 & 1968 & PS & Oil \\
\hline Strezhevoye Vostochnoye & OB & & & & SI & Oil \\
\hline Studenoye & OB & 61.84 & 70.93 & 1975 & SI & Oil \\
\hline Sugmutskoye & $\mathrm{OB}$ & 63.84 & 73.64 & 1987 & Si & Oil \\
\hline Surgutskoye Severnoye & OB & 61.74 & 73.44 & 1963 & PS & Gas \\
\hline Surgutskoye Vostochnny & & & & & & \\
\hline (Federovo-Surgut) & OB & 61.70 & 73.40 & 1977 & SI & Oil \\
\hline $\begin{array}{l}\text { Surgutskoye Yuzhnny } \\
\text { (Federovo) }\end{array}$ & $\mathrm{OR}$ & 6170 & 7340 & 1973 & PS & Oil \\
\hline Surgutskoye Zapadnoye & & & & & & \\
\hline (Federovo-Surgut) & OB & 61.70 & 73.40 & 1962 & PS & Oil \\
\hline Surprinskoye Vostochnoye & UR & 61.25 & 64.28 & 1986 & SI & Oil \\
\hline Sutorlinskove & $\mathrm{OB}$ & 61.30 & 73.50 & 1975 & DV & Oil \\
\hline Sutorminskoye & NP & 63.75 & 74.55 & 1975 & PS & Oil \\
\hline Sutorminskoye Yuzhnoye & NP & 63.48 & 74.78 & 1988 & SI & Oil \\
\hline Sutorminskoye Zapadnny & NP & 64.00 & 74.58 & & & Oil \\
\hline Suzunskove & PT & 68.34 & 83.60 & 1971 & SI & Oil \\
\hline Syadorskoye (Syadorakha) & YA & 71.60 & 69.16 & 1982 & SI & Gas \\
\hline Symor'yakhskoye & UR & 61.27 & 64.46 & 1988 & $\mathrm{SI}$ & Oil \\
\hline Syn'yeganskoye & FR & 61.65 & 69.45 & 1984 & SI & Oil \\
\hline Syskonsyninskoye & UR & 62.90 & 63.64 & 1961 & SI & Gas \\
\hline Syskonsynyaskoye & & & & & & \\
\hline Vostochnaya & UR & 62.96 & 63.92 & 1961 & PP & Gas \\
\hline Syskonsynyaskoye Yuzhnaya & UR & 62.88 & 63.70 & 1963 & DV & Gas \\
\hline Syskonsynyaskoye Zapadnaya & UR & 62.93 & 63.69 & 1961 & DV & Gas \\
\hline Tabaganskoye Yuzhnoye & KA & 57.29 & 78.96 & 1983 & SI & Oil \\
\hline Tagayskoye & KA & 57.97 & 76.02 & 1987 & SI & Oil \\
\hline Tagrinskoye & NP & 62.32 & 78.21 & 1975 & PS & Oil \\
\hline Tagul'skoye & PT & 67.75 & 82.78 & 1988 & SI & Oil \\
\hline Tal'nikovoye & UR & 60.97 & 63.66 & 1989 & SI & Oil \\
\hline Talinskoye & FR & 62.00 & 66.55 & & SI & Oil \\
\hline Talinskoye Zapadnoye & FR & 62.00 & 66.50 & 1992 & SI & Oil \\
\hline Tambayeyskoye Yuzhnoye & $\mathrm{KA}$ & 57.69 & 78.58 & 1986 & Si & Oil \\
\hline Tambeyskoye Severnoye & YA & 71.83 & 71.55 & 1982 & SI & Gas \\
\hline Tambeyskoye Yuzhnoye & YA & 71.21 & 71.95 & 1974 & DV & Gas \\
\hline Tambevskove Zapadnove & YA & 71.54 & 70.97 & 1985 & SI & Gas \\
\hline
\end{tabular}


Table 1D. Basic Field Information, West Siberian Basin (Sorted Alphabetically by Field Name) (Continued)

\begin{tabular}{|c|c|c|c|c|c|c|}
\hline Field Name & Region & $\begin{array}{l}\text { North } \\
\text { Latitude } \\
\text { (degrees) }\end{array}$ & $\begin{array}{c}\text { East } \\
\text { Latitude } \\
\text { (degrees) }\end{array}$ & $\begin{array}{c}\text { Discovery } \\
\text { Date }\end{array}$ & $\begin{array}{c}\text { Producing } \\
\text { Status }\end{array}$ & $\begin{array}{l}\text { Primary } \\
\text { Product }\end{array}$ \\
\hline Tanlovskoye Yuzhnoye & NF' & 64.49 & 75.20 & 1976 & PP & Oil \\
\hline Tanusalinskoye & NF' & 66.88 & 73.80 & 1987 & SI & Gas \\
\hline Taplorskoye & OE3 & 61.92 & 72.67 & 1978 & SI & Oil \\
\hline Tapskoye & PT & 64.58 & 78.82 & 1986 & SI & Oil \\
\hline \multicolumn{7}{|l|}{ Tarasovskoye } \\
\hline (Ayvasedopurskoye) & NF' & 64.47 & 77.73 & 1967 & PS & Oil \\
\hline Tarkhovskoye Severnoye & OES & 61.17 & 77.20 & 1981 & SI & Oil \\
\hline Tarkhovskove Yuzhnoye & OE & 61.10 & 77.07 & 1981 & SI & Oil \\
\hline Tarkhovskoye Zapadnoye & OE & 61.11 & 77.08 & 1987 & SI & Oil \\
\hline Tarko-Sale Vostochnoye & NF & 65.05 & 78.10 & 1971 & DV & Gas \\
\hline Tarko-Sale Yuzhnoye & NF & 63.97 & 78.59 & 1984 & SI & Oil \\
\hline Tarko-Sale Zapadnoye & NF & 64.79 & 77.20 & 1972 & PP & Gas \\
\hline Tarskoye Vostochnoye & KA & 56.86 & 78.86 & 1986 & SI & Oil \\
\hline Tasiyskoye & YA & 71.98 & 72.01 & 1988 & SI & Gas \\
\hline Tavlovskoye Yuzhnoye & NP & 64.57 & 75.08 & & SI & Oil \\
\hline Tay-Dasskoye (Dasskoye) & KA & 56.73 & 79.13 & 1971 & SI & Oil \\
\hline Tay-Dasskoye Vostochnoye & KA & 56.68 & 79.22 & & SI & Oil \\
\hline Taybinskoye (Lyantor) & $\mathrm{OB}$ & 61.87 & 72.13 & 1968 & SI & Gas \\
\hline Taylakovskoye & KA & 59.14 & 74.11 & 1964 & SI & Oil \\
\hline Taytymskoye & FR & 57.96 & 73.45 & 1975 & SI & Oil \\
\hline Tazskoye & PT & 67.39 & 78.92 & 1962 & PP & Oil \\
\hline Tazovskoye Vostochnoye & PT & 67.32 & 79.63 & 1980 & si & Gas \\
\hline Tekto-Kharampur & PT & 63.87 & 79.83 & 1990 & SI & Oil \\
\hline Teplin-Russkin & $O B$ & 62.25 & 73.50 & 1990 & PP & Oil \\
\hline Teplovskoye & $\mathrm{OB}$ & 60.76 & 72.47 & 1966 & PS & Oil \\
\hline Terel'skoye & $\mathrm{PT}$ & 64.38 & 80.04 & 1986 & SI & Gas \\
\hline Termokarstovoye & PT & 65.43 & 82.54 & 1988 & SI & Gas \\
\hline Teterevo-Mortyminskoye & UR & 60.41 & 64.63 & 1961 & PS & Oil \\
\hline \multicolumn{7}{|l|}{ Teterevskoye Severnoye } \\
\hline (Mortym) & UR & 60.41 & 64.97 & 1968 & PP & Oil \\
\hline \multicolumn{7}{|l|}{ Teterevskoye Vostochnoye } \\
\hline (Mortymin) & UR & 60.41 & 64.97 & 1964 & PS & Oil \\
\hline \multicolumn{7}{|l|}{ Teterevskoye Yuzhnoye } \\
\hline (Mortymin) & UR & 60.33 & 64.83 & 1963 & PS & Oil \\
\hline Tevlin-Konitlorskoye & $\mathrm{OB}$ & 62.50 & 73.68 & 1971 & PS & Oil \\
\hline Tevlinskoye & $\mathrm{OB}$ & 62.51 & 73.65 & 1972 & SI & Oil \\
\hline Tevrizskoye & FR & 57.55 & 72.29 & 1971 & SI & Gas \\
\hline Tevrizskoye Vostochnoye & FR & 57.52 & 72.30 & & SI & Gas \\
\hline Tochinskove & $O B$ & 62.18 & 72.25 & 1989 & SI & Oil \\
\hline Tolkinskoye & PT & 64.33 & 82.28 & 1989 & SI & GC \\
\hline Tolumskoye Vostochnoye & UR & 60.56 & 65.29 & 1967 & PP & Oil \\
\hline Tolumskoye Semividovskoye & UR & 60.75 & 65.33 & 1966 & PS & Oil \\
\hline Tolumskoye Servernoye & UR & 60.75 & 65.33 & 1966 & PS & Oil \\
\hline Tolumskoye Yuzhnoye & UR & 60.75 & 65.33 & 1966 & PS & Gas \\
\hline Tonchinskoye & OB & & & 1989 & SI & Oil \\
\hline Tortasinskoye & FR & 62.19 & 69.59 & 1989 & si & Oil \\
\hline Totayakhinskoye & GY & 69.14 & 76.52 & 1984 & DV & Gas \\
\hline Travyanoye & $\mathrm{KA}$ & 59.08 & 74.05 & & SI & Oil \\
\hline Trekhbugornoye & GY & 69.56 & 74.39 & 1990 & SI & Gas \\
\hline Trekhozernoye & UR & 60.21 & 64.70 & 1960 & PS & Oil \\
\hline Trekhozernoye Severnoye & UR & 60.21 & 64.70 & 1969 & PS & Oil \\
\hline
\end{tabular}


Table 1D. Basic Field Information, West Siberian Basin (Sorted Alphabetically by Field Name) (Continued)

\begin{tabular}{|c|c|c|c|c|c|c|}
\hline Field Name & Region & $\begin{array}{l}\text { North } \\
\text { Latitude } \\
\text { (degrees) }\end{array}$ & $\begin{array}{c}\text { East } \\
\text { Latitude } \\
\text { (degrees) }\end{array}$ & $\begin{array}{c}\text { Discovery } \\
\text { Date }\end{array}$ & $\begin{array}{l}\text { Producing } \\
\text { Status }\end{array}$ & $\begin{array}{l}\text { Primary } \\
\text { Product } \\
\end{array}$ \\
\hline Triyurtinskoye & UKN & & & 1988 & $\mathrm{SI}$ & Oil \\
\hline Triyurtinskoye Vostochnoye & UKN & & & 1988 & SI & Oil \\
\hline Trom-Yeganskoye & OB & 63.00 & 71.86 & 1986 & SI & Oil \\
\hline $\begin{array}{l}\text { Trom-Yeganskoye Severnoye } \\
\text { Trom-Yeganskoye }\end{array}$ & OB & 63.40 & 71.50 & 1993 & SI & Oil \\
\hline Vostochnoye & $O B$ & 61.37 & 74.57 & 1988 & SI & Oil \\
\hline Tsentralnoye & & & & & & \\
\hline (Khanty-Mansiyskoye) & FR & 62.62 & 67.55 & 1987 & Sl & Oil \\
\hline Tugiyanskoye & UR & 63.62 & 65.80 & 1960 & SI & Gas \\
\hline Tugrovskoye Severnoye & FR & 61.88 & 64.75 & 1992 & Si & Oil \\
\hline Tugrovskoye Vostochnoye & FR & 61.70 & 64.80 & 1989 & SI & Gas \\
\hline Tugrovskoye Zapadnoye & FR & & & & SI & Oil \\
\hline Tukanskoye & KA & 59.82 & 72.39 & 1963 & SI & Oil \\
\hline Tul'yeganskoye & VA & 61.35 & 77.90 & 1983 & SI & Oil \\
\hline Tumannoye & FR & 61.85 & 70.38 & 1974 & SI & Oil \\
\hline Tundrinskoye & $O B$ & 61.27 & 72.08 & 1981 & SI & Oil \\
\hline Tungolskoye & VA & 60.33 & 80.49 & 1973 & SI & Oil \\
\hline Tunkorskoye & FR & 62.36 & 68.30 & 1989 & SI & Oil \\
\hline Tutlimskoye (Tutlym) & OB & 62.05 & 72.07 & 1966 & DV & Oil \\
\hline Tyanovskoye & OB & 62.98 & 72.34 & 1986 & DV & Oil \\
\hline Tyumenskoye & OB & 61.65 & 77.62 & 1971 & PS & Oil \\
\hline Ubinskoye & UR & 60.74 & 64.87 & 1964 & PP & Oil \\
\hline Ubinskoye Lesser & UR & 60.82 & 64.83 & 1967 & PP & Oil \\
\hline Ubinskoye Servenoye & UR & 60.82 & 64.83 & 1964 & PP & Oil \\
\hline Ubinskoye Yuzhnoye & UR & 60.82 & 64.83 & 1965 & PP & Oil \\
\hline Ubinskoye Zapadnoye & UR & 60.82 & 64.83 & 1966 & PP & Oil \\
\hline Udachnoye & OB & 60.50 & 71.83 & & SI & Oil \\
\hline Udmurtskoye Yuzhnoye & UKN & & & 1992 & SI & Oil \\
\hline Ugutskoye & OB & 60.49 & 74.13 & 1985 & PS & Oil \\
\hline Ugutskoye Zapadnoye & OB & 60.46 & 73.73 & 1984 & PP & Oil \\
\hline Umseyskoye & NP & 64.08 & 74.39 & 1982 & PP & Oil \\
\hline Umseyskoye Vostochnoye & NP & 64.19 & 74.61 & 1988 & SI & Oil \\
\hline Unlorskoye & UKN & & & 1989 & $\mathrm{SI}$ & Oil \\
\hline Urengoyskoye (Pestsovoye) & NP & 66.95 & 75.36 & 1970 & $\mathrm{SI}$ & Gas \\
\hline \multicolumn{7}{|l|}{ Urengoyskoye (Samburg, } \\
\hline $\begin{array}{l}\text { Yevo-Yakha,Yen-Yakha, } \\
\text { Urengoy Sev.,Pestsovoye) }\end{array}$ & NP & 66.05 & 76.95 & 1966 & PP & Gas \\
\hline Urengoyskoye Severnoye & NP & 67.54 & 76.55 & 1970 & PP & Gas \\
\hline Urengoyskoye Vostochnoye & NP & 66.08 & 77.49 & 1978 & UKN & Gas \\
\hline Urmanskoye & $\mathrm{KA}$ & 57.62 & 78.45 & 1974 & SI & Oil \\
\hline Urnenskoye & KA & 58.66 & 73.38 & 1970 & SI & Oil \\
\hline \multicolumn{7}{|l|}{ Uryevskoye(-Potochnoye) } \\
\hline (Pokachev-Uryev) & OB & 61.42 & 75.45 & 1971 & PS & Oil \\
\hline Usanovskoye & $\mathrm{KA}$ & 58.56 & 73.68 & 1971 & $\mathrm{SI}$ & Oil \\
\hline Ust Chaselskoye & PT & 65.12 & 81.10 & 1981 & SI & Oil \\
\hline Ust Kharampur & PT & 64.30 & 78.19 & 1983 & PP & Oil \\
\hline Ust'-Sil'ginskoye & PA & 58.87 & 80.00 & 1961 & $\mathrm{SI}$ & Gas \\
\hline Ust-Balyk Zapadnoye & $\mathrm{OB}$ & 61.10 & 72.35 & 1985 & SI & Oil \\
\hline Ust-Balyk-Mamontovo & OB & 61.09 & 72.57 & 1961 & PS & Oil \\
\hline Ust-Kotukhtinskoye & OB & 62.50 & 76.00 & 1990 & SI & Oil \\
\hline Ust-Koyukhtaskoye & $O B$ & & & & SI & Oil \\
\hline
\end{tabular}


Table 1D. Basic Field Information, West Siberian Basin (Sorted Alphabetically by Field Name) (Continued)

\begin{tabular}{|c|c|c|c|c|c|c|}
\hline Field Name & Region & $\begin{array}{l}\text { North } \\
\text { Latitude } \\
\text { (degrees) }\end{array}$ & $\begin{array}{c}\text { East } \\
\text { Latitude } \\
\text { (degrees) }\end{array}$ & $\begin{array}{c}\text { Discovery } \\
\text { Date }\end{array}$ & $\begin{array}{c}\text { Producing } \\
\text { Status }\end{array}$ & $\begin{array}{l}\text { Primary } \\
\text { Product }\end{array}$ \\
\hline Ust-Yuribeyskoye & YA & 68.86 & 70.07 & 1989 & SI & Gas \\
\hline Utrenneye & GY & 70.95 & 74.63 & 1980 & DV & Gas \\
\hline Utrenneye Severnoye & GY & 71.07 & 74.07 & 1979 & SI & Gas \\
\hline Uzbekskoye & UR & 60.27 & 64.22 & 1988 & PP & Oil \\
\hline Uzbekskoye Severnoye & UR & 60.27 & 64.22 & 1989 & PP & Oil \\
\hline Uzbekskoye-Sredne-Chanchar & UR & 60.53 & 64.22 & 1988 & PS & Oil \\
\hline Uzbelskoye Yuzhnoye & UR & 60.27 & 64.22 & 1988 & SI & Oil \\
\hline Vachimskoye & OB & 61.81 & 72.62 & 1971 & PS & Oil \\
\hline Vadelypskoye & $\mathrm{OB}$ & 60.15 & 71.06 & 1989 & SI & Oil \\
\hline Vakh River & VA & & & 1965 & DV & Oil \\
\hline Vakh Severnoye & VA & 60.98 & 78.96 & 1967 & SI & Oil \\
\hline Vakh Yuzhnoye & VA & 60.85 & 78.98 & & SI & Oil \\
\hline Valyuninskoye Vosstochnoye & UKV & & & 1988 & SI & Oil \\
\hline Van'yeganskoye & NP & 61.85 & 77.23 & 1974 & PS & Oil \\
\hline Vankorskoye & UKIV & & & 1990 & SI & Oil \\
\hline Var'yeganskoye & NP & 62.11 & 77.57 & 1967 & PS & Oil \\
\hline Var'yeganskoye Severnoye & NP & 62.44 & 77.40 & 1971 & PS & Oil \\
\hline Var'yeganskoye Yuzhnoye & NP & 62.20 & 76.73 & 1982 & SI & Oil \\
\hline Var'yeganskoye Zapadnoye & NP & 62.31 & 76.69 & 1981 & PS & Oil \\
\hline Vartov-Sovetskoye & $\mathrm{OB}$ & 60.81 & 77.09 & 1962 & PS & Oil \\
\hline Vartovskoye & VA & 60.28 & 79.88 & 1968 & SI & Oil \\
\hline Vartovskoye-Sosino & $\mathrm{OB}$ & 60.77 & 77.35 & 1962 & DV & Oil \\
\hline Varyngskoye & PA & 62.67 & 80.17 & & SI & Oil \\
\hline Vasyuganskoye Severnoye & VA & 59.37 & 78.38 & 1964 & PP & Gas \\
\hline Vat'yeganskoye & $\mathrm{OB}$ & 62.15 & 75.32 & 1970 & PP & Oil \\
\hline Vat'yeganskoye Severnoye & $\mathrm{OB}$ & 62.40 & 75.30 & 1983 & Si & Oil \\
\hline Vat'yeganskoye Yuzhnoye & $\mathrm{OB}$ & 62.03 & 75.02 & 1971 & DV & Oil \\
\hline Vataskoye & $\mathrm{OB}$ & 61.17 & 75.78 & & SI & Oil \\
\hline Vataskoye Severnaya & $\mathrm{OB}$ & 61.20 & 75.80 & 1980 & PP & Oil \\
\hline Vatinskoye & OB & 61.25 & 75.90 & 1964 & PS & Oil \\
\hline Vengapur & NP & 63.09 & 76.59 & 1968 & PP & Gas \\
\hline Vengapur Severnoye & NP & 63.20 & 76.70 & 1992 & Si & Oil \\
\hline Vengapur Yuzhnoye & NP & 62.63 & 76.82 & 1973 & PP & Oil \\
\hline Vengapur Zapadnoye & NP & 63.17 & 76.35 & 1992 & Si & Oil \\
\hline \multicolumn{7}{|l|}{ Vengayakha } \\
\hline (Vengayakha Vost.) & NP & 63.97 & 76.90 & 1968 & PS & Gas \\
\hline Verkhne Chasel'kaskoye & PT & 65.20 & 80.40 & 1980 & SI & Oil \\
\hline Verkhne Nadymskoye & OB & 63.40 & 72.88 & 1992 & SI & Oil \\
\hline Verkhne-Kolikyeganskoye & PT & 62.42 & 80.15 & 1981 & PS & Oil \\
\hline \multicolumn{7}{|l|}{ Verkhne-Lyaminskoye } \\
\hline (Upper Lyama) & FR & 62.15 & 70.54 & 1970 & SI & Oil \\
\hline Verkhne-Salatskoye & VA & 58.48 & 78.04 & 1967 & SI & Oil \\
\hline Verkhnekambarskoye & VA & 57.50 & 80.28 & 1971 & SI & Gas \\
\hline Verkhnelem'inskoye & UR & 61.09 & 64.13 & 1966 & PS & Oil \\
\hline Verkhnepurpey & NP & 64.57 & 75.50 & 1976 & PP & Gas \\
\hline Verkhnesalymskoye & OB & 59.99 & 70.97 & 1966 & DV & Oil \\
\hline Verkhneshapshinskoye & OB & 60.82 & 70.34 & 1972 & SI & Oil \\
\hline Verkhnesuprinskoye & UR & 61.25 & 64.30 & 1986 & Si & Oil \\
\hline Verkhnetarskoye & $\mathrm{KA}$ & 56.74 & 78.75 & 1971 & PP & Oil \\
\hline Verkhnetiuteyskoye & YA & 70.77 & 69.89 & 1982 & SI & Gas \\
\hline Verkhniy Kazymskoye & FR & & & & SI & Oil \\
\hline
\end{tabular}


Table 1D. Basic Field Information, West Siberian Basin (Sorted Alphabetically by Field Name) (Continued)

\begin{tabular}{|c|c|c|c|c|c|c|}
\hline Field Name & Region & $\begin{array}{l}\text { North } \\
\text { Latitude } \\
\text { (degrees) }\end{array}$ & $\begin{array}{c}\text { East } \\
\text { Latitude } \\
\text { (degrees) }\end{array}$ & $\begin{array}{c}\text { Discovery } \\
\text { Date }\end{array}$ & $\begin{array}{c}\text { Producing } \\
\text { Status }\end{array}$ & $\begin{array}{l}\text { Primary } \\
\text { Product }\end{array}$ \\
\hline Verkhniy Kazymskoye & OB & 63.60 & 70.93 & 1990 & SI & Oil \\
\hline Verkhnyaya Kondaskoye & UR & 61.40 & 63.88 & 1963 & SI & Gas \\
\hline Vershinnoye & OB & 61.57 & 73.07 & 1964 & DV & Oil \\
\hline Veselovskoye & KA & 56.52 & 78.15 & 1965 & $\mathrm{SI}$ & Gas \\
\hline Vesennee & KA & 59.08 & 76.00 & 1973 & SI & Oil \\
\hline Vesenneye Zapadnoye & KA & & & & SI & Oil \\
\hline Vladigorskoye Yuzhnoye & OB & 60.50 & 71.50 & & SI & Oil \\
\hline Vonterskoye & VA & 61.75 & 79.13 & 1982 & SI & Oil \\
\hline Vostochnoye(Novosibirsk) & KA & 56.70 & 79.29 & 1986 & SI & Oil \\
\hline Vyintoy & OB & 62.90 & 75.78 & 1982 & SI & Oil \\
\hline Vyintoy Vostochnoye & $\mathrm{OB}$ & 62.86 & 75.93 & 1989 & SI & Oil \\
\hline Vyintoy Yuzhnoye & $\mathrm{OB}$ & 62.80 & 75.80 & 1988 & SI & Oil \\
\hline XXVII CPSU Congress & OB & 60.68 & 74.53 & & SI & Oil \\
\hline Yagunskoye & OB & 62.36 & 74.32 & 1978 & PS & Oil \\
\hline Yagunskoye Severnoye & OB & 62.70 & 74.45 & 1982 & DV & Oil \\
\hline Yagunskoye Vostochnoye & OB & 62.16 & 74.34 & 1982 & SI & Oil \\
\hline Yagunskoye Yuzhnoye & OB & 62.20 & 74.30 & 1979 & PS & Oil \\
\hline Yagyl'yakh & KA & 57.74 & 75.20 & 1982 & SI & Oil \\
\hline Yakhlaskoye & UR & 61.40 & 65.43 & 1971 & PS & Oil \\
\hline Yakhturskoye Severnoye & PT & 63.75 & 79.00 & & SI & Oil \\
\hline Yamburgskoye & NP & 67.98 & 75.84 & 1969 & PP & Gas \\
\hline Yamskoye & OB & 60.33 & 71.50 & & SI & Oil \\
\hline Yamsovey & NP & 65.56 & 75.32 & 1970 & DV & Gas \\
\hline Yangtaskoye Severnaya & NP & 64.23 & 74.94 & 1985 & SI & Oil \\
\hline Yaraynerskoye & NP & 63.17 & 77.79 & 1973 & PP & Oil \\
\hline Yaraynerskoye Severnoye & NP & 63.17 & 77.90 & 1987 & SI & Oil \\
\hline Yaraynerskoye Vostochnoye & NP & 63.08 & 77.89 & 1987 & SI & Oil \\
\hline Yaraynerskoye Yuzhnoye & NP & 62.75 & 78.01 & 1988 & SI & Oil \\
\hline Yareyskoye & NP & 65.18 & 75.85 & 1989 & SI & Gas \\
\hline Yarovoye & PT & 66.00 & 79.50 & 1991 & SI & Gas \\
\hline Yaroyakhskoye & PT & 66.23 & 78.75 & 1984 & PP & Gas \\
\hline Yaunlorskoye & OB & 61.52 & 72.93 & 1967 & PS & Oil \\
\hline Yefremovo & OB & 60.60 & 73.00 & 1989 & PP & Oil \\
\hline Yegur'yakh & OB & 61.72 & 76.40 & 1988 & SI & Oil \\
\hline Yegur'yakh Severnoye & OB & 61.77 & 76.31 & 1987 & SI & Oil \\
\hline Yegur'yakh Yuzhnoye & OB & 61.70 & 76.27 & 1990 & SI & Oil \\
\hline \multicolumn{7}{|l|}{ Yelizarovskoye } \\
\hline (Krasnoleninskoye) & FR & 61.48 & 67.77 & 1963 & SI & Oil \\
\hline Yelleyskoye(Yelley) & $\mathrm{KA}$ & 57.60 & 77.68 & 1983 & SI & Oil \\
\hline Yelovoye Vostochnoye & OB & 61.37 & 74.09 & 1987 & PP & Oil \\
\hline \multicolumn{7}{|l|}{ Yemyegovskoye } \\
\hline (Krasnoleninskoye) & FR & 61.75 & 66.42 & 1971 & DV & Oil \\
\hline Yendryskoye & FR & 59.97 & 69.28 & 1992 & SI & Oil \\
\hline Yenyakha & NP & 67.00 & 76.50 & 1976 & SI & Oil \\
\hline Yermakovo & OB & 60.79 & 76.09 & 1974 & PS & Oil \\
\hline Yermakovo Severnoye & OB & 60.80 & 76.10 & & SI & Oil \\
\hline Yershovskoye (Tyumen) & OB & 61.13 & 77.79 & 1979 & PS & Oil \\
\hline Yesetinskoye & PT & 66.42 & 77.58 & & SI & Oil \\
\hline Yesetinskoye Severnoye & PT & 66.50 & 77.50 & & Sl & Oil \\
\hline Yetypurskoye & NP & 63.95 & 77.63 & 1971 & DV & Gas \\
\hline Yevo-Yakha & NP & 65.85 & 77.30 & 1980 & SI & Gas \\
\hline
\end{tabular}


Table 1D. Basic Field Informaticn, West Siberian Basin (Sorted Alphabetically by Field Name) (Continued)

\begin{tabular}{lcccccc}
\hline Field Name & Region & $\begin{array}{c}\text { North } \\
\text { Latitude } \\
\text { (degrees) }\end{array}$ & $\begin{array}{c}\text { East } \\
\text { Latitude } \\
\text { (degrees) }\end{array}$ & $\begin{array}{c}\text { Discovery } \\
\text { Date }\end{array}$ & $\begin{array}{c}\text { Producing } \\
\text { Status }\end{array}$ & $\begin{array}{c}\text { Primary } \\
\text { Product }\end{array}$ \\
\hline Yubileynoye (Tyumen) & $\mathrm{NI}$ & 65.99 & 75.76 & 1969 & $\mathrm{PP}$ & Gas \\
Yubileynoye Vostochnoye & $\mathrm{NI}$ & 65.88 & 76.17 & 1988 & $\mathrm{SI}$ & Gas \\
Yugansk & $\mathrm{Ol}$ & & & 1975 & $\mathrm{SI}$ & Oil \\
Yumantyl' & $\mathrm{NP}$ & 65.06 & 72.89 & 1988 & $\mathrm{SI}$ & Oil \\
Yur'yevskoye Severnoye & $\mathrm{OB}$ & 61.99 & 72.98 & 1988 & $\mathrm{SI}$ & Oil \\
Yurkharovskoye & $\mathrm{NP}$ & 67.78 & 77.08 & 1970 & $\mathrm{SI}$ & Gas \\
Yutym Severnoye & $\mathrm{KA}$ & 59.00 & 74.16 & 1989 & $\mathrm{SI}$ & Oil \\
Yutyrmalskoye & $\mathrm{PT}$ & 64.82 & 81.41 & 1988 & $\mathrm{SI}$ & Gas \\
Yuzhnoye-1 & $\mathrm{OB3}$ & 60.63 & 75.91 & 1986 & $\mathrm{PP}$ & Oil \\
Yuzhnoye-2 & $\mathrm{OB3}$ & 60.62 & 76.01 & 1987 & $\mathrm{SI}$ & Oil \\
ZaOzernoye & $\mathrm{FFi}$ & 59.97 & 68.10 & 1987 & $\mathrm{SI}$ & Oil \\
Zapolyarnoye & $\mathrm{PT}$ & 66.87 & 79.63 & 1965 & $\mathrm{DV}$ & Gas \\
Zapolyarnoye Zapadnoye & $\mathrm{PT}$ & 66.70 & 78.78 & 1979 & $\mathrm{SI}$ & Gas \\
Zimneyeskoye & $\mathrm{GI}$ & 69.20 & 83.70 & 1977 & $\mathrm{DV}$ & Gas
\end{tabular}

Notes: $P P=P r o d u c i n g ~ P r i m a r y, ~ P S=P$ roducing Secondary, $D V=$ Developing, $S I=S h u t$ in, $A B N D=A b a n d o n e d, U K N=U n k n o w n$ $\mathrm{GC}=$ Gas Condensate, $\mathrm{YA}=$ Yamal, $\mathrm{G} Y=$ Gydian, $N P=$ Nadym-Pur, $P T=P u r-T a z, F R=$ Frolov, UR=Urals, $K A=K a y m y s o v, V A=V a s y u g a n$, $\mathrm{PA}=$ Padugin, $\mathrm{OB}=$ Middle $\mathrm{Ob}$. Alternate field names or field combinations in parenthesis.

Source: Energy information Administra tion, Office of Oil and Gas. 
Table 2D. Calculated Crude Oil, Natural Gas, and Condensate Recovery by Field, West Siberian Basin (Sorted Alphabetically by Field Name)

\begin{tabular}{|c|c|c|c|c|}
\hline Field Name & $\begin{array}{l}\text { Ultimate } \\
\text { Crude Oil } \\
\text { (million } \\
\text { barrels) } \\
\end{array}$ & $\begin{array}{l}\text { Associated- } \\
\text { Disolved Gas } \\
\text { (billion } \\
\text { cubic feet) } \\
\end{array}$ & $\begin{array}{l}\text { Nonassociated } \\
\text { Gas } \\
\text { (billion } \\
\text { cubic feet) } \\
\end{array}$ & $\begin{array}{l}\text { Condensate } \\
\text { (million } \\
\text { barrels) }\end{array}$ \\
\hline Achimovskoye (Achimov) & 210.42 & 62.75 & & \\
\hline Aganskoye & 1792.72 & 523.33 & & \\
\hline Aganskoye Yuzhnoye & 12.74 & 4.00 & & \\
\hline Aganskoye Zapadnoye & 1.53 & 0.48 & & \\
\hline Akaytemskoye & & & 15.00 & \\
\hline Alekhinskoye & 651.33 & 194.60 & & \\
\hline Alenkinskoye & 11.37 & 3.24 & & \\
\hline Alyasovskoye Severnoye & & & 36.18 & 0.44 \\
\hline Alyasovskoye Yuzhnoye & & & 48.52 & 0.55 \\
\hline Anomalnoye & 2.00 & 1.00 & & \\
\hline Antipayutaskoye & & & 12294.01 & \\
\hline Apakapurskoye & 80.93 & 63.53 & & \\
\hline Aprel'skoye & 51.92 & 14.07 & & \\
\hline Archinskoye & 59.72 & 22.04 & & \\
\hline Ariolskoye & 38.56 & 14.65 & & \\
\hline Arkticheskoye & & & 7831.83 & 77.07 \\
\hline Asomkinskoye & 22.95 & 6.24 & & \\
\hline Asomkinskoye Vostochnoye & 7.56 & 2.81 & & \\
\hline Asomkinskoye Yuzhnoye & 10.40 & 2.83 & & \\
\hline Asomkinskoye Zapadnoye & 88.08 & 36.55 & & \\
\hline Ay-Yaunskoye & 524.22 & 89.12 & 790.74 & \\
\hline Ayeganskoye & 33.74 & 22.82 & & \\
\hline Aykuruskoye & 144.08 & 54.46 & & \\
\hline Aypim Lobat-Yuganskoye (Ai Pim) & 486.10 & 61.94 & & \\
\hline Ayvasedopurskoye Severnoye & & & & \\
\hline (Tarasovskoye Sev.) & 46.20 & 36.54 & & \\
\hline Bakhilovskoye & 315.72 & 178.49 & & \\
\hline Balykskoye Yuzhnoye & 317.37 & 93.10 & & \\
\hline Barsukovskoye & & & 4531.10 & 222.02 \\
\hline Barsukov Zapadnoye & 2.49 & 2.23 & & \\
\hline Baydaratskoye & & & 344.72 & \\
\hline Beloyarskoye & & & 65.27 & 1.91 \\
\hline Beregovoye & 130.13 & 102.15 & 5777.28 & \\
\hline Berezovskoye (Tyumen) & & & 336.47 & 3.70 \\
\hline Bittemskoye & 74.13 & 21.94 & & \\
\hline Bol'shoye & 131.39 & 65.35 & & \\
\hline $\begin{array}{l}\text { Bol'shoye Kruzenshternskoye } \\
\text { (Kruzenshternskoye) }\end{array}$ & & & 20287.40 & \\
\hline Boloshekotukhtinskoye(Kotukhta) & 19.90 & 5.23 & & \\
\hline Bovanenkoskoye & & & 99681.21 & 217.10 \\
\hline Bovanenkoskoye Severnoye & & & 194.03 & \\
\hline Bovanenkoskoye Vostochnoye & & & 892.22 & \\
\hline Bugornaya-Vostochnaya & & & 174.70 & \\
\hline Bystrinskoye (Bystrin) & 1261.34 & 250.17 & & \\
\hline Chakhloneyskoye & 2.37 & 0.74 & & \\
\hline Chancharskoye Severnoye & 12.51 & 4.35 & & \\
\hline Chaselskoye Severnoye & & & 241.86 & \\
\hline Chatylkynskoye & 52.51 & 29.57 & & \\
\hline Chebachyeskoye & 297.55 & 109.80 & & \\
\hline Cheremshanskoye Yuzhnoye & 20.24 & 3.95 & & \\
\hline
\end{tabular}


Table 2D. Calculated Crude Oil, Natural Gas, and Condensate Recovery by Field, West Siberian Basin (Sorted Alphab itically by Field Name) (Continued)

\begin{tabular}{|c|c|c|c|c|}
\hline Field Name & $\begin{array}{l}\text { Ultimate } \\
\text { Crude Oil } \\
\text { (million } \\
\text { barrels) }\end{array}$ & $\begin{array}{l}\text { Associated- } \\
\text { Disolved Gas } \\
\text { (billion } \\
\text { cubic feet) }\end{array}$ & $\begin{array}{l}\text { Nonassociated } \\
\text { Gas } \\
\text { (billion } \\
\text { cubic feet) } \\
\end{array}$ & $\begin{array}{c}\text { Condensate } \\
\text { (million } \\
\text { barrels) }\end{array}$ \\
\hline Chernichnoye & 26.91 & 15.25 & & \\
\hline Chernogorskoye & 199.52 & 74.97 & & \\
\hline Chistinnoye & 61.05 & 16.02 & & \\
\hline Chkalovskoye & 23.57 & 15.24 & 221.77 & 4.44 \\
\hline Chuelskoye & & & 174.13 & 1.92 \\
\hline Chukhlorskoye & 22.13 & 8.94 & & \\
\hline Chumpaskoye & 205.63 & 52.93 & & \\
\hline Chupal'skoye & 241.87 & 68.93 & & \\
\hline Chupal'skoye Severnoye & 160.20 & 45.66 & & \\
\hline Chvorovoye (Vasyuganskiy) & 3.81 & 1.44 & & \\
\hline Danilovskoye & 89.21 & 28.73 & & \\
\hline Danilovskoye Severnoye & 12.51 & 4.35 & & \\
\hline Danilovskoye Vostochnoye & 12.51 & 4.35 & & \\
\hline Danilovskoye Zapadnoye & 12.51 & 4.35 & & \\
\hline Dekabr'skoye & 4.17 & 1.70 & & \\
\hline Deminskoye & & & 149.82 & 1.78 \\
\hline Demyanskoye Severnoye & 20.66 & 3.39 & & \\
\hline Dobrovol'skoye & 54.08 & 26.93 & & \\
\hline Druzhnoye & 1354.11 & 264.67 & & \\
\hline Duklinskoye & 27.37 & 10.35 & & \\
\hline Dunayevskoye & 24.55 & 7.71 & & \\
\hline Dvoynoye & 5.01 & 1.89 & & \\
\hline Em-Yakhtinskoye & & & 478.28 & \\
\hline Enitorskoye & 39.05 & 14.76 & & \\
\hline Enitorskoye Yuzhnoye & 11.17 & 6.87 & & \\
\hline Erginskoye & 94.61 & 14.76 & & \\
\hline Erginskoye Vostochnoye & 255.96 & 73.79 & & \\
\hline Fainskoye & 132.04 & 48.99 & & \\
\hline Fedorovskoye & 1792.45 & 808.46 & 1133.65 & 20.41 \\
\hline Fedyushkinskoye & 113.32 & 13.37 & & \\
\hline Fedyushkinskoye Severnoye & 2.71 & 0.35 & & \\
\hline Festivalnoye (Tomsk)(Aykagol'skoj'e) & 236.55 & 52.08 & & \\
\hline Festivalnoye (Tyumen)(Kamy) & 40.16 & 8.83 & & \\
\hline Festivalnoye Yuzhno & 7.36 & 2.78 & & \\
\hline Filippovskoye & 10.58 & 3.33 & & \\
\hline Fobosskoye & 38.07 & 12.60 & & \\
\hline Frolovskoye Vostochnoye & 108.67 & 33.43 & & \\
\hline Galleyskoye & 3.77 & 1.27 & & \\
\hline Galyanovskoye & 439.81 & 183.40 & & \\
\hline Gaz-Sale & & & 257.34 & 9.01 \\
\hline Geofizicheskoye & & & 4832.79 & 11.79 \\
\hline Gerasimovskoye & 49.67 & 18.50 & 106.29 & 3.11 \\
\hline Glukhovskoye & 4.09 & 1.55 & & \\
\hline Golevoyeskoye & 17.01 & 7.36 & & \\
\hline Gornoye (Tyumen) & & & 89.36 & 0.98 \\
\hline Gorshkovskoye Zapadnoye & 70.03 & 21.64 & & \\
\hline Gorstovoye & 7.67 & 2.39 & & \\
\hline Gribnoye & 72.09 & 27.33 & & \\
\hline Grushevoye & 28.49 & 7.49 & & \\
\hline Gubkinskoye Severnoye & 342.50 & 313.76 & 624.07 & 30.58 \\
\hline
\end{tabular}


Table 2D. Calculated Crude Oil, Natural Gas, and Condensate Recovery by Field, West Siberian Basin (Sorted Alphabetically by Field Name) (Continued)

\begin{tabular}{|c|c|c|c|c|}
\hline Field Name & $\begin{array}{l}\text { Ultimate } \\
\text { Crude Oil } \\
\text { (million } \\
\text { barrels) }\end{array}$ & $\begin{array}{l}\text { Associated- } \\
\text { Disolved Gas } \\
\text { (billion } \\
\text { cubic feet) } \\
\end{array}$ & $\begin{array}{l}\text { Nonassociated } \\
\text { Gas } \\
\text { (billion } \\
\text { cubic feet) } \\
\end{array}$ & $\begin{array}{c}\text { Condensate } \\
\text { (million } \\
\text { barrels) }\end{array}$ \\
\hline Gubkinskoye (Gubkin Sev., Prisklonoye) & 0.22 & 0.17 & 10580.14 & 0.16 \\
\hline Gun-Yeganskoye & 98.13 & 38.04 & & \\
\hline Gustorechenskoye & 25.27 & 9.55 & & \\
\hline Gydanskoye & & & 1626.86 & \\
\hline lgol'sko-Talovoye & 143.75 & 31.77 & & \\
\hline Igrim Severnoye & & & 123.20 & 1.36 \\
\hline Igrim Yuzhnoye & & & 95.25 & 1.05 \\
\hline Ikilorskoye & 250.18 & 86.82 & & \\
\hline Imlorskoye & 24.55 & 7.81 & & \\
\hline Imlorskoye Zpapadnny & 24.55 & 7.81 & & \\
\hline Ingaskoye (Inginsk)(Krasnoleninskoye) & 18.22 & 6.72 & & \\
\hline Ininskoye & 5.14 & 1.94 & & \\
\hline lokhturskoye Severnoye & 22.67 & 12.84 & & \\
\hline Istochnoye & 24.55 & 7.80 & & \\
\hline It'yakhskoye & 9.11 & 3.36 & & \\
\hline Izvestinskoye & 64.63 & 57.91 & & \\
\hline Kalchinskoye & 33.07 & 5.52 & & \\
\hline Kalchinskoye Severnoye & 11.12 & 9.82 & & \\
\hline Kalinovoye & 191.60 & 2912.44 & 455.90 & 17.49 \\
\hline Kalinovoye Severnoye & 30.39 & 12.40 & 533.59 & 28.71 \\
\hline Kalinovoye Vostochnoye & 0.22 & 0.10 & & \\
\hline Kamennomysskoye & & & 1363.72 & \\
\hline Kamennoye(Krasnoleninskoye) & 58.88 & 14.80 & & \\
\hline Kamynskoye & 153.88 & 53.41 & & \\
\hline Kamynskoye Severnoye & 254.88 & 80.14 & & \\
\hline Kamynskoye Yuzhnoye & 60.66 & 19.09 & & \\
\hline Karabashskoye(Leninskoye) & & & 20.42 & 0.22 \\
\hline Karamovskoye & 383.90 & 81.84 & & \\
\hline Karamovskoye Severnoye & 31.41 & 7.10 & & \\
\hline Karasevskoye (Tomsk) & 30.89 & 11.68 & & \\
\hline Karasevskoye (Tyumen) & 54.30 & 48.65 & & \\
\hline Karasevskoye Severnoye & 10.47 & 3.96 & & \\
\hline Karasevskoye Zapadnoye & 11.12 & 9.82 & & \\
\hline Karayskoye (Karayskoye) & 25.11 & 6.23 & & \\
\hline Karayskoye Zapadnoye & 17.97 & 6.79 & & \\
\hline Karempostskoye & 8.53 & 4.11 & & \\
\hline Kartop'ya & 40.43 & 27.98 & & \\
\hline Kartopya Zapadnoye & 0.40 & 0.09 & & \\
\hline Kartopya-Okhanskoye & 8.49 & 1.80 & & \\
\hline Karyaunskoye & 3.82 & 1.09 & & \\
\hline Katyl'ginskoye & 150.91 & 35.13 & & \\
\hline Katyl'ginskoye Zapadnoye & 21.37 & 4.86 & & \\
\hline Kayumovskoye & 14.11 & 6.65 & & \\
\hline Kazanskoye & & & 1702.66 & 26.35 \\
\hline Kazantsevskoye(UstYenisey) & & & 409.87 & \\
\hline Kazymskoye Severnoye & & & 292.43 & 3.22 \\
\hline Kechimovskoye & 24.55 & 7.81 & & \\
\hline Kechimovskoye Yuzhnoye & 24.55 & 7.81 & & \\
\hline Ketovskoye & 216.48 & 47.73 & & \\
\hline Khadyryakhaskoye & & & 434.66 & \\
\hline
\end{tabular}


Table 2D. Calculated Crude Oil, Natural Gas, and Condensate Recovery by Field, West Siberian Basin (Sorted Alphabetically by Field Name) (Continued)

\begin{tabular}{|c|c|c|c|c|}
\hline Field Name & $\begin{array}{l}\text { Ultimate } \\
\text { Crude Oil } \\
\text { (million } \\
\text { barrels) }\end{array}$ & $\begin{array}{l}\text { Associated- } \\
\text { Disolved Gas } \\
\text { (billion } \\
\text { cubic feet) }\end{array}$ & $\begin{array}{l}\text { Nonassociated } \\
\text { Gas } \\
\text { (billion } \\
\text { cubic feet) }\end{array}$ & $\begin{array}{l}\text { Condensate } \\
\text { (million } \\
\text { barrels) }\end{array}$ \\
\hline
\end{tabular}

Khadyryakhaskoye Yuzhnaya

Khalmerpayuta

Khambateyskoye

Khancheyskoye (or Khangey)

Khanty-Mansiyskoye (Tsentralnoye)

Kharam-Pur Yuzhnoye

Kharampur (Kharampur Yuz.)

Kharampur Zapadnoye

Kharasaveyskoye

Kharvutinskoye

Khay-Yakhinskoye

Khokhlovskoye

Khokhryakov

Khokhryakov Severnoye

Kholmistoye

Kholmogoryskoye

Khorlorskoye

Khorlorskoye Verkhniy

Khulturskoye

Khulymskoye Yuzhnoye

Khvoynoye

Kinyaminskoye Yuzhnoye

Kinyaminskoye

Kislorskoye

Kiyevyeganskoye

Klyuchevskoye (Tomsk)

Kochevskoye Severnoye

Kochevskoye(Tevlin-Konitlor)

Kogolymskoye

Kogolymskoye Severnoye

Kogolymskoye Yuzhnoye

Kolikyeganskoye

Kolikyeganskoye Vostochnoye

Kolotuchnoye

Komar'inskoye

Komsomol'skoye (Barsukovskoye)

Komsomolskoye Severnoye

Kondakovskoye (Tomsk)

Kondinskoye Vostochnaya

Konitlorskoye Severnoye

Konitlorskoye Vostochnoye

Konitlorskoye Yuzhnoye

Konitlorskoye Zapadnoye

Konitlorskoye(Tevlin-Konitlor)

Koshilsko-Vakhskoye

Kotukhtaskoye Zapadnoye

Krapivinskoye

Krapivinskoye Severnoye

Krapivinskoye Vostochnoye

Krasnoleninskoye
15.31

171.59

97.67

634.43

32.94

57.06

7.55

6.24

353.42

187.28

23.73

722.86

41.05

24.55

72.22

69.33

13.99

9.35

2.00

16.21

19.95

28.82

24.55

128.88

433.46

27.02

13.25

13.24

11.17

293.43

30.59

9.43

11.17

221.37

20.39

818.68

100.93

101.64

388.68

93.80

150.28

17.31

34.22
12.02

39.06

103.54

485.37

18.66

28.42

4.16

2.47

146.32

189.23

8.56

190.78

11.70

7.73

25.09

21.85

6.03

4.09

1.00

5.45

8.84

10.66

7.74

40.61

129.73

8.53

4.19

5.01

6.87

110.92

9.67

4.45

6.87

107.95

6.45

373.08

31.92

31.94

239.04

29.65

50.50

3.25

5.99
23190.35

4052.30

106.76

528.42

98.62

1.13

3080.19

17927.84

14.82

16783.40

346.91

135.51

2.44

77.22

2.44

4.10 
Table 2D. Calculated Crude Oil, Natural Gas, and Condensate Recovery by Field, West Siberian Basin (Sorted Alphabetically by Field Name) (Continued)

\begin{tabular}{|c|c|c|c|c|}
\hline Field Name & $\begin{array}{l}\text { Ultimate } \\
\text { Crude Oil } \\
\text { (million } \\
\text { barrels) } \\
\end{array}$ & $\begin{array}{c}\text { Associated- } \\
\text { Disolved Gas } \\
\text { (billion } \\
\text { cubic feet) } \\
\end{array}$ & $\begin{array}{l}\text { Nonassociated } \\
\text { Gas } \\
\text { (billion } \\
\text { cubic feet) } \\
\end{array}$ & $\begin{array}{l}\text { Condensat } \\
\text { (million } \\
\text { barrels) }\end{array}$ \\
\hline Krasnoyarskoye Zapadnoye & 16.12 & 6.09 & & \\
\hline Kraynyeye & 165.21 & 82.28 & & \\
\hline Kruzenshternskoye Yuzhnoye & & & 3511.07 & \\
\hline Kudrinsk & 10.39 & 2.96 & & \\
\hline Kul'yeganskoye (Tyumen) & 18.85 & 4.54 & & \\
\hline Kulginskoye & 2.00 & 1.00 & & \\
\hline Kulyeganskoye(Tomsk) & 19.52 & 5.08 & & \\
\hline Kurraganskoye & 27.17 & 8.81 & & \\
\hline Kurraganskoye Yuzhnoye & 7.05 & 2.15 & & \\
\hline Kustovoye Yuzhnoye & 3.57 & 1.13 & & \\
\hline Kvartovoye & 80.38 & 8.68 & & \\
\hline Kynskoye & & & 55.40 & \\
\hline Kysomskoye & 7.07 & 2.0 & & \\
\hline Larkinskoye & 35.68 & 11.26 & & \\
\hline Larlomin Yuzhnoye & 11.12 & 9.82 & & \\
\hline Larlomkinskoye & 5.12 & 1.33 & & \\
\hline Lasyeganskoye(Pokachev-Ur'yev) & 232.36 & 59.93 & & \\
\hline Lazarevskoye & 12.51 & 4.35 & & \\
\hline Lebyazhyeskoye & & & 691.73 & 7.61 \\
\hline Ledovoye Severnoye (Tomsk) & 24.55 & 7.75 & & \\
\hline Ledovoye (Tomsk) & 21.43 & 7.95 & & \\
\hline Ledyanoye & 9.01 & 2.69 & & \\
\hline Lem'inskoye Vostochnoye & 11.74 & 4.08 & & \\
\hline Lem'inskoye Zapadnoye & 11.74 & 4.08 & & \\
\hline Leminskoye (Lemya) & 5.05 & 1.86 & & \\
\hline $\begin{array}{l}\text { Lempinskoye Zapadno(Pravdinsk-Salym) } \\
\text { Leningradskoye }\end{array}$ & 45.10 & 16.73 & & \\
\hline Leninskoye(Karabashskoye) & & & 52.32 & 0.58 \\
\hline Lenzitskoye & 163.80 & 83.87 & & \\
\hline Limbayakhaskoye & 42.13 & 23.78 & & \\
\hline Lineynoye & 6.77 & 2.10 & & \\
\hline Lokosovo & 565.99 & 143.64 & & \\
\hline Lomovoye & 118.92 & 66.41 & & \\
\hline Lontyn'yakh & 16.14 & 3.44 & & \\
\hline Lopukhovskoye & 12.51 & 4.35 & & \\
\hline Lorbinskoye & 8.11 & 1.15 & & \\
\hline Loryeganskoye & 27.29 & 3.86 & & \\
\hline Losevoye & 9.92 & 4.89 & & \\
\hline Lovinskoye & 55.97 & 25.74 & & \\
\hline Lovinskoye Zapadnoye & 158.51 & 58.49 & & \\
\hline Lower Tabaganskoye & 20.85 & 129.04 & 55.73 & 1.63 \\
\hline Luginetskoye & & & 386.86 & 11.33 \\
\hline Luginetskoye Zapadnoye & 11.17 & 6.87 & & \\
\hline Lyantorskoye (Taybinskoye) & 2321.63 & 685.97 & & \\
\hline Lykhminskoye & 4.09 & 0.92 & & \\
\hline Maksimkinskoye & 2.00 & 1.00 & & \\
\hline Malo Kolikyeganskoye & 11.17 & 6.87 & & \\
\hline Malo-Aganskoye Yuzhnoye & 5.61 & 1.77 & & \\
\hline Malo-Perevalnoye & 24.55 & 7.75 & & \\
\hline Malo-Tolumskoye & 1.81 & 0.63 & & \\
\hline
\end{tabular}


Table 2D. Calculated Crude Oil, Natural Gas, and Condensate Recovery by Field, West Siberian Basin (Sorted Alphabetically by Field Name) (Continued)

\begin{tabular}{|c|c|c|c|c|}
\hline Field Name & $\begin{array}{l}\text { Ultimate } \\
\text { Crude Oil } \\
\text { (million } \\
\text { barrels) } \\
\end{array}$ & $\begin{array}{l}\text { Associated- } \\
\text { Disolved Gas } \\
\text { (billion } \\
\text { cubic feet) }\end{array}$ & $\begin{array}{l}\text { Nonassociated } \\
\text { Gas } \\
\text { (billion } \\
\text { cubic feet) } \\
\end{array}$ & $\begin{array}{c}\text { Condensate } \\
\text { (million } \\
\text { barrels) }\end{array}$ \\
\hline Malobalykskoye & 537.35 & 130.98 & & \\
\hline Malochernogorskoye & 105.21 & 39.19 & & \\
\hline Malodanilovskoye & 12.51 & 4.35 & & \\
\hline Maloichskoye & 36.10 & 12.18 & & \\
\hline Maloklyuchevoye & 85.38 & 56.79 & & \\
\hline Malokustovoye & 6.12 & 1.93 & & \\
\hline Maloledyanoye & 23.47 & 4.89 & & \\
\hline Malonovogodneye & 4.79 & 4.29 & & \\
\hline Malopokachevskoye & 24.55 & 7.75 & & \\
\hline Malopotanayskoye & 1.81 & 0.63 & & \\
\hline Malopriobskoye & 32.42 & 10.89 & & \\
\hline Malopyakutaskoye & 67.29 & 21.27 & & \\
\hline Malorechenskoye & 198.18 & 94.12 & & \\
\hline Malovar'yeganskoye & 10.19 & 8.56 & & \\
\hline Malovat'yeganskoye & 6.12 & 1.93 & & \\
\hline Maloveselovskoye & 1.94 & 0.35 & & \\
\hline Maloyagunskoye & 24.55 & 7.75 & & \\
\hline Maloyamalskoye(Lesser Yamal) & & & 604.73 & \\
\hline Maloyuganskoye Severnoye & 24.55 & 7.75 & & \\
\hline Maloyuganskoye & 171.27 & 116.68 & & \\
\hline Malyginskoye & & & 2865.93 & \\
\hline Mamontovskoye(Ust-Balyk) & 616.20 & 153.57 & & \\
\hline Mangazeyskoye & 45.18 & 14.64 & & \\
\hline Maslikhovskoye & 18.22 & 6.45 & & \\
\hline Matyushkinskoye & 8.64 & 2.20 & & \\
\hline Mayskoye (W Siberia) & 123.41 & 35.78 & & \\
\hline Medvezhyeskoye & 0.11 & 0.09 & 54896.48 & \\
\hline Megionskoye & 630.17 & 193.79 & & \\
\hline Meretayakhskoye & 95.83 & 85.86 & & \\
\hline Messoyakhskoye Vostochnaya & 179.01 & 21.66 & 495.65 & \\
\hline Messoyakhskoye Yuzhnaya & & & 792.63 & \\
\hline Messoyakhskoye Zapadnaya & 211.06 & 165.68 & & \\
\hline $\begin{array}{l}\text { Messoyakhskoye (Norilisk City1970) } \\
\text { (Yenisey-Khatanga) }\end{array}$ & & & 843.28 & \\
\hline Mezhovskoye & 119.27 & 36.85 & & \\
\hline Mezhovskoye Vostochnoye & 50.57 & 20.74 & & \\
\hline Minchimkskoye & 111.75 & 34.61 & & \\
\hline Minchimkskoye Severnaya & 0.29 & 0.07 & & \\
\hline Minkhovskoye & & & 263.34 & \\
\hline Minkhovskoye Vostochnoye & & & 409.87 & \\
\hline Mirnoye & & & 861.53 & 25.24 \\
\hline Mogutlorskoye & 17.84 & 5.64 & & \\
\hline Mogutlorskoye Zapadnoye & 13.25 & 4.19 & & \\
\hline Moiseyevskoye & 29.25 & 6.58 & & \\
\hline Moiseyevskoye Zapadnoye & 9.53 & 3.60 & & \\
\hline Mokhovoye Vostochnoye & 91.64 & 21.46 & & \\
\hline Mokhtikovskoye & 23.67 & 9.23 & & \\
\hline Mortym'yaskoye Severnoye & 92.65 & 30.22 & & \\
\hline Mortym'yaskoye Yuzhnoye & 22.41 & 9.40 & & \\
\hline Mortym'yaskoye Zapadnoye 1 & 12.51 & 4.35 & & \\
\hline
\end{tabular}


Table 2D. Calculated Crude Oil, Natural Gas, and Condensate Recovery by Field, West Siberian Basin (Sorted Alphabetically by Field Name) (Continued)

\begin{tabular}{llclc}
\hline & Ultimate & Associated- & Nonassociated & \\
& Crude Oil & Disolved Gas & Gas & Condensate \\
(million & (billion & (billion & (million \\
Field Name & barrels) & cubic feet) & cubic feet) & barrels) \\
\hline
\end{tabular}

Mortym'yaskoye Zapadnoye 2

Mortym'yaskoye Zapadnoye 3

Multanovskoye

Mulym'yaskoye

Mulymyaskoye Srednyaya

Mulymyaskoye Zapadnaya

Muravlenko

Muryaunskoye

Mykhlorskoye

Mykhpayskoye(Samotlor)

Myldzhinskoye

Myldzhinskoye Yuzhnoye

Nadymskoye

Nakhodkaskoye

Nalim'yeskoye

Nazinskoye Yuzhnoye

Nazymskoye

Neponyatnoye

Nerstinskoye

Ney-To (Neytinskoye)

Nezhdannoye

12.51

cubic feet)

(billion

barrels)

Nikol'skoye (Tomsk)

Nikol'skoye (Tyumen)

Nivagalskoye(Pokachev-Ur'yev)

Nizhne Khetskoye (Yenisey-Khatanga)

Nizhne Tabaganskoye

Nizhne-Shapshinskoye

Nizhne-Sortymskoye

Nizhne-Tobolyanskoye

Nizhnevartovsk

Nizhniy Keumskoye

Nong'yeganskoye

Nong'yeganskoye Vostochnoye

18.38

4.35

41.91

4.28

18.79

15.84

16.91

5.92

1.35

6.24

816.81

2.00

3.89

304.48

35.00

0.47

376.16

1.00

1.10

86.03

9.97

8959.91

199.55

17.26

6.53

17.75

3.73

80.11

26.92

64.57

57.86

$6.26 \quad 4.91$

$\begin{array}{ll}4.37 & 1.62\end{array}$

$\begin{array}{ll}9.40 & 2.88\end{array}$

$11.17 \quad 6.87$

1487.92

384.76

111.58

24.55

161.42

1.13

24.44

11.12

1337.97

25.49

Novoaganskoye

Novochaselskoye

Novogodneyeskoye

Novogodneyeskoye Zapadnoye

79.67

260.28

143.20

2.95

Novomolodezhnoye

232.65

224.34

134.69

Novoportovskoye

438.01

Novopurpeyskoye

Novoyendyrskoye

Novyy-Tutymskoye

160.7

11.12

Noyabr'skoye Zapadnoye

249.30

42.14

7.82

48.68

0.12

7.72

9.82

580.93

8.05

71.38

146.90

86.94

2.37

132.71

363.29

30.20

154.15

59.30

9.82

72.91

629.14

1227.61

3857.11

Nulin-Turskoye

Nurminskoye

Nydinskoye

Ob River Area

Okhanskoye

112.69

12.51

Okhteurskoye Vostochnoye

11.17

943.95

3.74

58.71

0.10

100.41

6422.57

151.58

10.66

0.12

3437.06

14.75

33.18

110.41

4.35

6.87 
Table 2D. Calculated Crude Oil, Natural Gas, and Condensate Recovery by Field, West Siberian Basin (Sorted Alphabitically by Field Name) (Continued)

\begin{tabular}{|c|c|c|c|c|}
\hline Field Name & $\begin{array}{l}\text { Ultimate } \\
\text { Crude Oil } \\
\text { (million } \\
\text { barrels) } \\
\end{array}$ & $\begin{array}{l}\text { Associated- } \\
\text { Disolved Gas } \\
\text { (billion } \\
\text { cubic feet) } \\
\end{array}$ & $\begin{array}{l}\text { Nonassociated } \\
\text { Gas } \\
\text { (billion } \\
\text { cubic feet) } \\
\end{array}$ & $\begin{array}{l}\text { Condensate } \\
\text { (million } \\
\text { barrels) } \\
\end{array}$ \\
\hline Okhteurskoye Yuzhnny & 24.16 & 8.12 & & \\
\hline Ol'khovskoye (Tyumen) & 427.54 & 50.02 & & \\
\hline Olen'yeskoye & 1089.17 & 351.80 & & \\
\hline Olen'yeskoye Severnoye & 27.24 & 11.47 & & \\
\hline Ombinskoye & 22.20 & 8.24 & & \\
\hline Ontokhskoye & 344.37 & 135.68 & & \\
\hline Orekhovskoye Severnoye & 24.55 & 7.82 & & \\
\hline Orekhovoskoye & 19.78 & 7.34 & & \\
\hline Osomkinskoye Zapadnoye & 24.55 & 7.82 & & \\
\hline Ostaninskoye & 76.80 & 38.55 & 1451.68 & 52.48 \\
\hline Ostaninskoye Severnoye & 4.89 & 2.54 & & \\
\hline Ostaninskoye Zapadnoye & 14.27 & 6.73 & & \\
\hline Ostrovnoye & 5.55 & 2.37 & & \\
\hline Ostrovnoye Severnoye & 8.03 & 1.46 & & \\
\hline Ostrovnoye Yuzhnoye & 24.55 & 7.76 & & \\
\hline Otdelnoye & 43.50 & 8.53 & & \\
\hline Ozernoye (Tomsk) & 15.77 & 8.12 & & \\
\hline Ozernoye (Vostochnoye \& Zapadncye) & & & 8.07 & 0.09 \\
\hline Pal'nikovskoye & 8.35 & 3.10 & & \\
\hline Palyanovskoye & 280.53 & 42.63 & & \\
\hline Pangodyskoye & 170.59 & 75.75 & 1726.22 & \\
\hline Parusovoye & 70.54 & 55.37 & & \\
\hline Paul-Turskoye & & & 8.98 & 0.10 \\
\hline Pavlovskoye (Tomsk) & 18.16 & 16.03 & & \\
\hline Paysyataskoye & 161.67 & 605.94 & & \\
\hline Paytykhskoye & 86.52 & 29.07 & & \\
\hline Pelyatkinskoye (Yenisey-Khatanga) & & & 1985.80 & \\
\hline Perekatnoye & & & 211.90 & \\
\hline Pereval'noye Vostochnoye & 196.65 & 46.61 & & \\
\hline Perevalnoye Yuzhnoye & 24.55 & 7.76 & & \\
\hline Permyakovskoye & 150.44 & 30.42 & & \\
\hline Pervomayskoye (Tomsk) & 108.85 & 28.19 & & \\
\hline Peschanoye & 13.19 & 3.50 & & \\
\hline Pestsovoye Zapadnoye & & & 2885.48 & \\
\hline Petelinskoye & 202.21 & 37.11 & & \\
\hline Pil'tanskoye & 24.55 & 7.76 & & \\
\hline Pindzhinskoye & 63.01 & 7.25 & & \\
\hline Pionerskoye & 11.17 & 6.87 & & \\
\hline Pogranichnoye (Tyumen) & 225.97 & 51.36 & & \\
\hline $\begin{array}{l}\text { Pokachevsko-Ur'yevskoye (Akhskoye, } \\
\text { Lasyeganskoye, Nivagalskoye, } \\
\text { Potochnoye, Potochnoye Severnoy,e, } \\
\text { Pokachevskoye Yuzhnoye, }\end{array}$ & & & & \\
\hline Ur'yevskoye) & 5281.87 & 1507.62 & & \\
\hline $\begin{array}{l}\text { Pokachevskoye Severnoye } \\
\text { (Pokachev-Ur'yev) }\end{array}$ & & & & \\
\hline Pokachevskoye Vostochnoye & 16.82 & 5.32 & & \\
\hline Pokachevskoye Yuzhnoye(Pokachev-Ur & Jr'yev) & & & \\
\hline Pokamasovskoye & 357.53 & 144.38 & & \\
\hline Pokamasovskoye Yuzhnoye & 24.55 & 7.81 & & \\
\hline
\end{tabular}


Table 2D. Calculated Crude Oil, Natural Gas, and Condensate Recovery by Field, West Siberian Basin (Sorted Alphabetically by Field Name) (Continued)

\begin{tabular}{|c|c|c|c|c|}
\hline Field Name & $\begin{array}{l}\text { Ultimate } \\
\text { Crude Oil } \\
\text { (million } \\
\text { barrels) }\end{array}$ & $\begin{array}{l}\text { Associated- } \\
\text { Disolved Gas } \\
\text { (billion } \\
\text { cubic feet) }\end{array}$ & $\begin{array}{l}\text { Nonassociated } \\
\text { Gas } \\
\text { (billion } \\
\text { cubic feet) } \\
\end{array}$ & $\begin{array}{c}\text { Condensate } \\
\text { (million } \\
\text { barrels) }\end{array}$ \\
\hline $\begin{array}{l}\text { Pokamasovskoye Zapadnoye } \\
\text { Pokhromskoye }\end{array}$ & 24.55 & 7.81 & 889.34 & 9.78 \\
\hline Pokurskoye Severskoye & 398.12 & 79.43 & & \\
\hline Poludennoye (Tomsk) & 74.80 & 18.48 & & \\
\hline Poludennoye (Tyumen) & 622.66 & 104.82 & & \\
\hline Poludennoye Severnoye & 11.17 & 6.87 & & \\
\hline Polun'yakhskoye & 11.12 & 9.82 & & \\
\hline Pomaliyakhskoye Severnoye & 6.20 & 1.77 & & \\
\hline Pon'zhevoye & 4.37 & 0.59 & & \\
\hline Poselkovoye & 6.14 & 1.38 & & \\
\hline Posnokortskoye & 2.00 & 1.00 & & \\
\hline Potanayskoye & 95.50 & 90.25 & & \\
\hline Potanayskoye Severnoye & 3.32 & 1.41 & & \\
\hline Potanayskoye Vostochnoye & 1.81 & 0.63 & & \\
\hline Potanayskoye Yuzhnoye & 15.87 & 6.69 & & \\
\hline Potochnoye Severnoye(Poka-Ury) & 376.54 & 107.31 & & \\
\hline Potochnoye(Poka-Ury) & 337.15 & 84.66 & & \\
\hline Pottymskoye & 26.84 & 3.25 & & \\
\hline Povkhovskoye & 2100.71 & 797.07 & & \\
\hline Povkhovskoye Severnoye & 24.55 & 7.76 & & \\
\hline Povkhovskoye Yuzhnoye & 24.55 & 7.76 & & \\
\hline Pravdinsk-Salymskoye & 2255.19 & 656.06 & & \\
\hline Pridorozhnoye Vostochnoye & 24.55 & 7.82 & & \\
\hline Priobskoye & 4219.82 & 1202.65 & & \\
\hline Priobskoye Severnoye & 6.81 & 2.29 & & \\
\hline Priobskoye Zapadnoye & 1.30 & 0.40 & & \\
\hline Prirakhtovskoye & 5.03 & 1.86 & & \\
\hline Prisklonovoye & 32.23 & 28.88 & & \\
\hline Promezhutochnoye & 24.55 & 7.82 & & \\
\hline Protochnoye & 49.63 & 9.53 & & \\
\hline Protochnoye Severnoye & 2.64 & 0.48 & & \\
\hline Protochnoye Yuzhnoye & 1.76 & 0.32 & & \\
\hline Puglalymskoye & 141.34 & 431.08 & & \\
\hline Pulpuyakhskove & 185.03 & 92.14 & & \\
\hline Punginskoye & & & 544.84 & 5.99 \\
\hline Purovskoye Severnoye & & & 923.65 & \\
\hline Purpeyskoye Yuzhnoye & 12.97 & 5.22 & & \\
\hline Purpeyskoye Zapadnoye & 35.85 & 32.12 & & \\
\hline Pyakutaskoye & 45.88 & 14.50 & & \\
\hline Pyakutaskoye Vostochnoye & 61.82 & 17.62 & & \\
\hline Pyakyakhinskoye & & & 1494.14 & \\
\hline Pyamaliyakhskoye Severnoye & 64.43 & 57.73 & & \\
\hline Pylinskoye & 32.94 & 23.98 & & \\
\hline Pylinskoye Zapadnoye & 24.55 & 7.75 & & \\
\hline Pyrey (Pyreynoye) & & & 77.79 & \\
\hline Pyreynoye Yuzhnove & 342.08 & 170.35 & 1124.35 & \\
\hline Rakitinskoye & 148.49 & 28.21 & & \\
\hline Ravenskoye & 36.00 & 13.35 & & \\
\hline Ravninnoye & 66.25 & 37.39 & & \\
\hline Rechnoye & & & 5.65 & 0.11 \\
\hline
\end{tabular}


Table 2D. Calculated Crude Oil, Natural Gas, and Condensate Recovery by Field, West Siberian Basin (Sorted Alphabetically by Field Name) (Continued)

\begin{tabular}{|c|c|c|c|c|}
\hline Field Name & $\begin{array}{l}\text { Ultimate } \\
\text { Crude Oil } \\
\text { (million } \\
\text { barrels) } \\
\end{array}$ & $\begin{array}{l}\text { Associated- } \\
\text { Disolved Gas } \\
\text { (billion } \\
\text { cubic feet) } \\
\end{array}$ & $\begin{array}{l}\text { Nonassociated } \\
\text { Gas } \\
\text { (billion } \\
\text { cubic feet) } \\
\end{array}$ & $\begin{array}{l}\text { Condensate } \\
\text { (million } \\
\text { barrels) }\end{array}$ \\
\hline Rodnikovoye & 352.28 & 100.40 & & \\
\hline Rogozhnikovskoye & 1388.21 & 246.20 & & \\
\hline Rogozhnikovskoye Severnoye & 32.42 & 10.89 & & \\
\hline Rogozhnikovskoye Yuzhnoye & 14.42 & 4.84 & & \\
\hline Rogozhnikovskoye Zapadnoye & 32.42 & 10.89 & & \\
\hline Romanovskoye & 103.86 & 21.91 & & \\
\hline Roslaviskoye & 76.46 & 32.50 & & \\
\hline Rostovtsevskoye & & & 629.14 & \\
\hline Rubinovoye & 3.07 & 0.70 & & \\
\hline Ruch'yevskoye & 2.76 & 1.20 & & \\
\hline Ruf'yeganskoye & 4.78 & 1.72 & & \\
\hline \multicolumn{5}{|l|}{ Rusanovskoye } \\
\hline Russkinskoye(Tevlin-Konit.) & 71.68 & 21.91 & & \\
\hline Russkorechenskoye & 123.04 & 69.44 & & \\
\hline Russkoye & 2702.07 & 402.61 & 2804.31 & \\
\hline Russkoye Yuzhnoye & & & 16121.27 & \\
\hline Ryamnoye & 6.10 & 2.76 & & \\
\hline Rybalnoye & 19.77 & 7.47 & & \\
\hline Sakhalinskoye (Tyumen) & 90.49 & 22.10 & & \\
\hline Sakhalinskoye Vostochnoye & 60.46 & 17.78 & & \\
\hline Salekaptskoye & 189.29 & 106.84 & & \\
\hline Salymskoye & 24.55 & 7.75 & & \\
\hline Salymskoye Central (Srednesalym) & 104.32 & 29.73 & & \\
\hline Salymskoye Severnny & 163.66 & 46.64 & & \\
\hline Salymskoye Vostochnoye & 19.88 & 6.28 & & \\
\hline Salymskoye Zapadnoye & 65.25 & 20.64 & & \\
\hline Samburgskoye Yuzhnoye(Urengoy) & 157.46 & 78.42 & & \\
\hline Samburgskoye (Urengoy) & 692.04 & 344.63 & & \\
\hline \multicolumn{5}{|c|}{ Samotlorskoye (Vata, Megion, Pokur Sev., } \\
\hline Mykhpay, Orekhovo Sev.) & 24660.99 & 11879.84 & 3161.97 & \\
\hline Sandibinskoye & 63.30 & 29.69 & & \\
\hline Saporkinskoye & 36.91 & 10.52 & 47.20 & 0.85 \\
\hline Sardakovskoye Yuzhnoye & 15.29 & 4.83 & & \\
\hline Savuyskoye & 291.32 & 83.90 & & \\
\hline Saygataskoye & 150.53 & 36.46 & & \\
\hline Selimkhanov & 116.57 & 45.08 & 16.38 & 0.48 \\
\hline Selivonikskoye & 10.54 & 6.38 & & \\
\hline Seliyarovskoye & 12.97 & 10.89 & & \\
\hline Seliyarovskoye Severnoye & 48.98 & 8.82 & & \\
\hline $\begin{array}{l}\text { Semakovskoye-Anderpayuta } \\
\text { Semividovskoye Vostochnoye }\end{array}$ & & & 30198.29 & \\
\hline $\begin{array}{l}\text { Severnoye } \\
\text { Seyakhinskoye Zapadnoye }\end{array}$ & 241.61 & 80.63 & $\begin{array}{r}782.87 \\
2298.15\end{array}$ & 15.54 \\
\hline Shapshinskoye & 124.62 & 35.52 & & \\
\hline Shchuch'yeskoye & 41.42 & 24.11 & & \\
\hline Sheburskoye Vostochnoye & 12.04 & 1.69 & & \\
\hline Shinginskoye & 12.30 & 5.30 & & \\
\hline Shirokovskoye & 89.77 & 25.80 & & \\
\hline Shirotnoye & 47.32 & 17.89 & & \\
\hline Shtomovoye & & & 15.00 & \\
\hline
\end{tabular}


Table 2D. Calculated Crude Oil, Natural Gas, and Condensate Recovery by Field, West Siberian Basin (Sorted Alphabetically by Field Name) (Continued)

\begin{tabular}{|c|c|c|c|c|}
\hline Field Name & $\begin{array}{l}\text { Ultimate } \\
\text { Crude Oil } \\
\text { (million } \\
\text { barrels) } \\
\end{array}$ & $\begin{array}{l}\text { Associated- } \\
\text { Disolved Gas } \\
\text { (billion } \\
\text { cubic feet) } \\
\end{array}$ & $\begin{array}{l}\text { Nonassociated } \\
\text { Gas } \\
\text { (billion } \\
\text { cubic feet) }\end{array}$ & $\begin{array}{c}\text { Condensate } \\
\text { (million } \\
\text { barrels) }\end{array}$ \\
\hline Shukhtungortskoye Vostochnny & & & 149.86 & 1.65 \\
\hline Shukhtungortskoye Zapadnoye & & & 92.74 & 1.02 \\
\hline Shukhtungortskoye & & & 135.96 & 1.50 \\
\hline Shushminskoye & 65.94 & 23.96 & & \\
\hline Shushminskoye Severnoye & 6.49 & 2.40 & & \\
\hline Shushminskoye Yuzhnoye & 12.51 & 4.36 & & \\
\hline Siktorskoye Severnoye & 49.65 & 46.88 & & \\
\hline Sil'ginskoye Severnoye & & & 244.63 & 7.17 \\
\hline Slavinskoye & 12.51 & 4.38 & & \\
\hline Smolyanoye & 6.43 & 2.43 & & \\
\hline Snezhnoye & 37.04 & 14.00 & & \\
\hline Sobolinoye & 183.05 & 28.56 & & \\
\hline Soimlorskoye Severnoye & 87.66 & 36.56 & & \\
\hline Sokhtymskoye & 2.00 & 1.00 & & \\
\hline Soleninskoye Severnoye(UstYenisey) & & & 409.87 & \\
\hline Soleninskoye Yuzhno (Ust Yenisey) & & & 561.30 & 12.30 \\
\hline Soletskoye & & & 1893.51 & \\
\hline Solkinskoye Zapadnoye & 7.06 & 1.61 & & \\
\hline Solonovskoye & 10.60 & 4.45 & & \\
\hline Sorominskoye & 5.13 & 1.90 & & \\
\hline Sorominskoye Severnoye & 2.55 & 0.81 & & \\
\hline Sorominskoye Zapadnoye & 0.51 & 0.16 & & \\
\hline Sortymskoye & 24.55 & 7.77 & & \\
\hline Sorymskoye & 33.08 & 8.27 & & \\
\hline Sosnovomysskoye(Krasnoleninskoye) & 140.33 & 51.78 & & \\
\hline Sote-Yuganskoye Severnoye & & & 10.52 & 0.12 \\
\hline Sote-Yuganskoye Yuzhnoye & & & 91.37 & 1.01 \\
\hline Sote-Yuganskoye & & & & \\
\hline Sovetskoye & 6050.59 & 1579.28 & & \\
\hline Sporishevskoye & 2.00 & 1.00 & & \\
\hline Srede-Kharampur & 7.55 & 4.14 & & \\
\hline Sredne Khulymskoye & 354.46 & 101.02 & & \\
\hline Sredne-Imurskoye & 2.00 & 1.00 & & \\
\hline Sredne-Iterskoye & 24.55 & 7.82 & & \\
\hline Sredne-Shapshinskoye & 24.55 & 7.82 & & \\
\hline Sredne-Vasyuganskoye & 254.82 & 75.53 & 93.65 & 2.74 \\
\hline Sredne-Vatlorskoye & 64.22 & 16.12 & & \\
\hline Sredneasomkinskoye & 34.15 & 10.81 & & \\
\hline Srednebalyk & 104.79 & 14.73 & 584.50 & 10.52 \\
\hline Srednechernogorskoye & 22.83 & 8.63 & & \\
\hline Srednekondinskoye & 2.00 & 1.00 & & \\
\hline Srednenazymskoye & 136.59 & 96.32 & & \\
\hline Srednenyurol'skoye & 132.64 & 23.88 & & \\
\hline Srednesil'ginskoye & & & 40.39 & 0.32 \\
\hline Sredneteterevskoye & 12.51 & 4.36 & & \\
\hline Sredneugutskoye & 24.55 & 7.78 & & \\
\hline Sredneyamalskoye & & & 16678.72 & 26.02 \\
\hline Sredniy Lykhmskoye & 72.10 & 24.22 & & \\
\hline Sredne Nazymskoye & & & & \\
\hline Stakhanovskoye & 661.27 & 243.96 & & \\
\hline
\end{tabular}


Table 2D. Calculated Crude Oil, Natural Gas, and Condensate Recovery by Field, West Siberian Basin (Sorted Alphab etically by Field Name) (Continued)

\begin{tabular}{|c|c|c|c|c|}
\hline Field Name & $\begin{array}{l}\text { Ultimate } \\
\text { Crude Oil } \\
\text { (million } \\
\text { barrels) } \\
\end{array}$ & $\begin{array}{l}\text { Associated- } \\
\text { Disolved Gas } \\
\text { (billion } \\
\text { cubic feet) } \\
\end{array}$ & $\begin{array}{l}\text { Nonassociated } \\
\text { Gas } \\
\text { (billion } \\
\text { cubic feet) } \\
\end{array}$ & $\begin{array}{l}\text { Condensate } \\
\text { (million } \\
\text { barrels) } \\
\end{array}$ \\
\hline Stakhanovskoye Severnoye & 42.13 & 23.78 & & \\
\hline Stavropolskoye & 2.00 & 1.00 & & \\
\hline Stolbovoye & 82.71 & 23.16 & & \\
\hline Strezhevoye & 28.63 & 7.19 & & \\
\hline Strezhevoye Vostochnoye & 3.06 & 0.97 & & \\
\hline Studenoye & 40.28 & 21.71 & & \\
\hline Sugmutskoye & 3327.14 & 768.57 & & \\
\hline Surgutskoye Severnoye & 431.28 & 85.18 & 1137.75 & 20.48 \\
\hline Surgutskoye Vostochnny & & & & \\
\hline (Federovo-Surgut) & 125.68 & 34.08 & & \\
\hline Surgutskoye Yuzhnny(Federovo) & 1540.86 & 356.26 & & \\
\hline Surgutskoye Zapadnoye & & & & \\
\hline (Federovo-Surgut) & 787.05 & 177.33 & & \\
\hline Surprinskoye Vostochnoye & 2.00 & 1.00 & & \\
\hline Sutorlinskoye & 42.23 & 12.04 & & \\
\hline Sutorminskoye & 2479.98 & 1364.58 & & \\
\hline Sutorminskoye Yuzhnoye & 24.68 & 22.11 & & \\
\hline Sutorminskoye Zapadnny & 39.13 & 19.49 & & \\
\hline Suzunskoye & 389.37 & 193.90 & 2424.70 & \\
\hline Syadorskoye (Syadorakha) & & & 413.15 & \\
\hline Symor'yakhskoye & 12.51 & 4.36 & & \\
\hline Syn'yeganskoye & 54.46 & 21.27 & & \\
\hline Syskonsyninskoye & & & 1513.39 & 16.65 \\
\hline Syskonsynyaskoye Vostochnaya & & & 242.79 & 2.67 \\
\hline Syskonsynyaskoye Yuzhnaya & & & 91.41 & 1.01 \\
\hline Syskonsynyaskoye Zapadnaya & & & 188.38 & 2.07 \\
\hline Tabaganskoye Yuzhnoye & 4.71 & 2.22 & & \\
\hline Tagayskoye & 152.48 & 25.62 & & \\
\hline Tagrinskoye & 374.81 & 71.82 & & \\
\hline Tagul'skoye & 95.64 & 17.79 & & \\
\hline Tal'nikovoye & 56.83 & 20.97 & & \\
\hline Talinskoye & 299.39 & 110.47 & & \\
\hline Talinskoye Zapadnoye & 32.42 & 10.89 & & \\
\hline Tambayeyskoye Yuzhnoye & 2.76 & 1.02 & & \\
\hline Tambeyskoye Severnoye & & & 1932.39 & 22.80 \\
\hline Tambeyskoye Yuzhnoye & & & 2177.27 & \\
\hline Tambeyskoye Zapadnoye & & & 1946.63 & \\
\hline Tanlovskoye Yuzhnoye & 143.29 & 128.39 & & \\
\hline Tanusalinskoye & & & 331.01 & \\
\hline Taplorskoye & 3.70 & 1.37 & 175.55 & 3.16 \\
\hline Tapskoye & 109.22 & 60.90 & & \\
\hline Tarasovskoye (Ayvasedopurskoye) & 4117.24 & 3191.67 & 2675.57 & 15.33 \\
\hline Tarkhovskoye Severnoye & 8.08 & 2.93 & & \\
\hline Tarkhovskoye Yuzhnoye & 2.22 & 0.80 & & \\
\hline Tarkhovskoye Zapadnoye & 5.54 & 2.53 & & \\
\hline Tarko-Sale Vostochnoye & 422.77 & 131.68 & 4122.40 & 26.90 \\
\hline Tarko-Sale Yuzhnoye & 79.63 & 71.35 & & \\
\hline Tarko-Sale Zapadnoye & 80.15 & 39.92 & 2709.00 & \\
\hline Tarskoye Vostochnoye & 1.60 & 0.71 & & \\
\hline Tasiyskoye & & & 1853.87 & \\
\hline
\end{tabular}


Table 2D. Calculated Crude Oil, Natural Gas, and Condensate Recovery by Field, West Siberian Basin (Sorted Alphabetically by Field Name) (Continued)

\begin{tabular}{|c|c|c|c|c|}
\hline Field Name & $\begin{array}{l}\text { Ultimate } \\
\text { Crude Oil } \\
\text { (million } \\
\text { barrels) } \\
\end{array}$ & $\begin{array}{l}\text { Associated- } \\
\text { Disolved Gas } \\
\text { (billion } \\
\text { cubic feet) } \\
\end{array}$ & $\begin{array}{l}\text { Nonassociated } \\
\text { Gas } \\
\text { (billion } \\
\text { cubic feet) } \\
\end{array}$ & $\begin{array}{c}\text { Condensate } \\
\text { (million } \\
\text { barrels) }\end{array}$ \\
\hline Tavlovskoye Yuzhnoye & 129.02 & 115.60 & & \\
\hline Tay-Das (Dasskoye) & 3.94 & 1.49 & & \\
\hline Tay-Das Vostochnoye & 11.12 & 9.82 & & \\
\hline Taybinskoye (Lyantor) & & & 178.02 & 3.20 \\
\hline Taylakovskoye & 15.23 & 5.76 & & \\
\hline Taytymskoye & 23.99 & 8.85 & & \\
\hline Tazovskoye & 462.50 & 363.06 & 4278.68 & 50.49 \\
\hline Tazovskoye Vostochnoye & & & 2603.30 & \\
\hline Tekto-Kharampur & 2.00 & 1.00 & & \\
\hline Teplin-Russkinskoye & 230.83 & 85.64 & & \\
\hline Teplovskoye & 867.99 & 185.66 & & \\
\hline Terel'skoye & & & 869.32 & \\
\hline Termokarstovoye & & & 918.46 & 45.00 \\
\hline Teterevo-Mortyminskoye & 341.37 & 120.71 & 888.28 & 9.77 \\
\hline Teterevskoye Severnoye(Mortym) & 62.80 & 22.21 & & \\
\hline Teterevskoye Vostochnoye(Mortymin) & 12.69 & 1.76 & & \\
\hline Teterevskoye Yuzhnoye(Mortymin) & 146.62 & 54.39 & 80.70 & 0.89 \\
\hline Tevlin-Konitlorskoye & 530.15 & 167.95 & & \\
\hline Tevlinskoye & 350.49 & 99.89 & & \\
\hline Tevrizskoye & & & 124.86 & 2.25 \\
\hline Tevrizskoye Vostochnoye & & & 75.19 & 1.35 \\
\hline Tochinskoye & 19.86 & 7.37 & & \\
\hline Tolkinskoye & & & 364.13 & 8.74 \\
\hline Tolumskoye Vostochnoye & 29.69 & 10.95 & & \\
\hline Tolum-Semividovskoye & & & & \\
\hline Tolumskoye Servernoye & 40.97 & 7.73 & & \\
\hline Tolumskoye Yuzhnoye & 25.42 & 5.00 & & \\
\hline Tonchinskoye & 24.55 & 7.78 & & \\
\hline Tortasinskoye & 66.90 & 18.06 & & \\
\hline Totayakhinskoye & & & 1563.24 & \\
\hline Travyanoye & 49.65 & 9.82 & & \\
\hline Trekhbugornoye & & & 2822.40 & 26.69 \\
\hline Trekhozernoye & 161.19 & 45.83 & & \\
\hline Trekhozernoye Severnoye & 23.10 & 11.97 & & \\
\hline Triyurtinskoye & 2.00 & 1.00 & & \\
\hline Triyurtinskoye Vostochnoye & 2.00 & 1.00 & & \\
\hline Trom-Yeganskoye & 236.21 & 65.14 & & \\
\hline Trom-Yeganskoye Severnoye & 9.78 & 3.10 & & \\
\hline Trom-Yeganskoye Vostochnoye & 12.00 & 3.81 & & \\
\hline Tsentralnoye (Khanty-Mansiyskoye) & 37.32 & 18.73 & & \\
\hline Tugiyanskoye & & & 2.13 & 0.02 \\
\hline Tugrovskoye Severnoye & 59.82 & 22.07 & & \\
\hline Tugrovskoye Vostochnoye & 78.70 & 26.44 & & \\
\hline Tugrovskoye Zapadnoye & 32.42 & 10.89 & & \\
\hline Tukanskoye & 226.04 & 85.44 & & \\
\hline Tul'yeganskoye & 3.38 & 2.08 & & \\
\hline Tumannoye & 12.06 & 3.68 & & \\
\hline Tundrinskoye & 35.42 & 16.15 & & \\
\hline Tungolskoye & 6.30 & 1.68 & & \\
\hline Tunkorskoye & 7.53 & 2.53 & & \\
\hline
\end{tabular}


Table 2D. Calculated Crude Oil, Natural Gas, and Condensate Recovery by Field, West Siberian Basin (Sorted Alphabetically by Field Name) (Continued)

\begin{tabular}{|c|c|c|c|c|}
\hline Field Name & $\begin{array}{l}\text { Ultimate } \\
\text { Crude Oil } \\
\text { (million } \\
\text { barrels) } \\
\end{array}$ & $\begin{array}{l}\text { Associated- } \\
\text { Disolved Gas } \\
\text { (billion } \\
\text { cubic feet) } \\
\end{array}$ & $\begin{array}{l}\text { Nonassociated } \\
\text { Gas } \\
\text { (billion } \\
\text { cubic feet) } \\
\end{array}$ & $\begin{array}{l}\text { Condensate } \\
\text { (million } \\
\text { barrels) } \\
\end{array}$ \\
\hline Tutlimskoye (Tutlym) & 33.10 & 9.43 & & \\
\hline Tyanovskoye & 1237.75 & 2.00 & & \\
\hline Tyumenskoye & 244.63 & 63.34 & 158.18 & \\
\hline Ubinskoye & 6.40 & 2.36 & & \\
\hline Ubinskoye Lesser & 5.57 & 1.08 & & \\
\hline Ubinskoye Servenoye & 7.60 & 1.47 & & \\
\hline Ubinskoye Yuzhnoye & 3.83 & 0.55 & & \\
\hline Ubinskoye Zapadnoye & 5.20 & 1.00 & & \\
\hline Udachnoye & 24.55 & 7.82 & & \\
\hline Udmurtskoye Yuzhnoye & 2.00 & 1.00 & & \\
\hline Ugutskoye & 184.69 & 48.51 & & \\
\hline Ugutskoye Zapadnoye & 15.68 & 6.47 & & \\
\hline Umseyskoye & 247.05 & 90.93 & & \\
\hline Umseyskoye Vostochnoye & 9.55 & 8.56 & & \\
\hline Unlorskoye & 2.00 & 1.00 & & \\
\hline Urengoyskoye (Pestsovoye) & 293.56 & 230.44 & 4955.25 & \\
\hline \multicolumn{5}{|c|}{ Urengoyskoye (Samburg,Yevo-Yakna, } \\
\hline Yen-Yakha,Urengoy Sev.,Pestsovoye) & 6617.30 & 404.15 & 269586.82 & 1858.08 \\
\hline Urengoyskoye Severnoye & & & 23117.35 & 41.78 \\
\hline Urengoyskoye Vostochnoye & & & 1115.97 & 39.06 \\
\hline Urmanskoye & 225.63 & 85.29 & & \\
\hline Urnenskoye & 16.32 & 10.41 & & \\
\hline \multicolumn{5}{|l|}{ Uryevskoye(-Potochnoye) } \\
\hline (Pokachev-Ur'yev) & 735.80 & 205.17 & & \\
\hline Usanovskoye & 63.40 & 23.97 & & \\
\hline Ust Chaselskoye & 211.21 & 105.18 & 394.35 & 15.40 \\
\hline Ust Kharampur & 52.60 & 28.82 & & \\
\hline Ust'-Sil'ginskoye & & & 489.43 & 11.26 \\
\hline Ust-Balykskoye Zapadnoye & 2.55 & 0.81 & & \\
\hline Ust-Balykskoye-Mamontovo & 2134.36 & 454.22 & & \\
\hline Ust-Kotukhtinskoye & 24.55 & 7.76 & & \\
\hline Ust-Koyukhtaskoye & 24.55 & 7.79 & & \\
\hline Ust-Yuribeyskoye & & & 524.54 & \\
\hline Utrenneye & & & 7041.36 & \\
\hline Utrenneye Severnoye & & & 1783.42 & \\
\hline Uzbekskoye & 191.95 & 70.83 & & \\
\hline Uzbekskoye Severnoye & 12.51 & 4.36 & & \\
\hline Uzbekskoye-Sredne-Chanchar & 17.01 & 5.93 & & \\
\hline Uzbelskoye Yuzhnoye & 12.51 & 4.36 & & \\
\hline Vachimskoye & 515.79 & 173.57 & & \\
\hline Vadelypskoye & 73.91 & 23.44 & & \\
\hline Vakh River & 38.57 & 12.65 & & \\
\hline Vakh Severnoye & 0.71 & 0.27 & & \\
\hline Vakh Yuzhnoye & 32.01 & 6.80 & & \\
\hline Valyuninskoye Vosstochnoye & 2.00 & 1.00 & & \\
\hline Van'yeganskoye & 1135.66 & 457.64 & 1264.33 & 34.66 \\
\hline Vankorskoye & 2.00 & 1.00 & & \\
\hline Var'yeganskoye & 2091.55 & 8336.78 & 496.21 & \\
\hline Var'yeganskoye Severnoye & 1292.93 & 1699.88 & 412.54 & 8.25 \\
\hline Var'yeganskoye Yuzhnoye & 73.70 & 61.44 & & \\
\hline
\end{tabular}


Table 2D. Calculated Crude Oil, Natural Gas, and Condensate Recovery by Field, West Siberian Basin (Sorted Alphabetically by Field Name) (Continued)

\begin{tabular}{|c|c|c|c|c|}
\hline Field Name & $\begin{array}{l}\text { Ultimate } \\
\text { Crude Oil } \\
\text { (million } \\
\text { barrels) } \\
\end{array}$ & $\begin{array}{l}\text { Associated- } \\
\text { Disolved Gas } \\
\text { (billion } \\
\text { cubic feet) } \\
\end{array}$ & $\begin{array}{l}\text { Nonassociated } \\
\text { Gas } \\
\text { (billion } \\
\text { cubic feet) } \\
\end{array}$ & $\begin{array}{l}\text { Condensate } \\
\text { (million } \\
\text { barrels) }\end{array}$ \\
\hline Var'yeganskoye Zapadnoye & 213.47 & 112.01 & & \\
\hline Vartov-Sovetskoye & 272.70 & 101.17 & & \\
\hline Vartovskoye & 6.03 & 57.51 & & \\
\hline Vartovskoye-Sosino & 3001.85 & 1079.54 & & \\
\hline Varyngskoye & 97.64 & 36.91 & & \\
\hline Vasyuganskoye Severnoye & & & 390.179 & 1.951 \\
\hline Vat'yeganskoye & 3987.53 & 1087.74 & & \\
\hline Vat'yeganskoye Severnoye & 29.68 & 8.35 & & \\
\hline Vat'yeganskoye Yuzhnoye & 17.40 & 6.46 & & \\
\hline Vataskoye & 86.66 & 27.48 & & \\
\hline Vataskoye Severnaya & 24.55 & 7.79 & & \\
\hline Vatinskoye & 1130.17 & 306.23 & & \\
\hline Vengapurskoye & 595.91 & 1814.72 & 5722.36 & \\
\hline Vengapurskoye Severnoye & 64.39 & 57.69 & & \\
\hline Vengapurskoye Yuzhnoye & 899.51 & 365.95 & & \\
\hline Vengapurskoye Zapadnoye & 64.39 & 57.69 & & \\
\hline Vengayakhaskoye (Vengayakha Vost.) & 501.34 & 189.42 & 3635.31 & \\
\hline Verkhne Chasel'kaskoye & 13.04 & 10.23 & & \\
\hline Verkhne Nadymskoye & 24.55 & 7.79 & & \\
\hline Verkhne-Kolikyeganskoye & 4896.64 & 3040.00 & 3615.02 & 4.49 \\
\hline Verkhne-Lyaminskoye (Upper Lyama) & 57.59 & 29.84 & & \\
\hline Verkhne-Salatskoye & 17.19 & 24.95 & 49.35 & 1.45 \\
\hline Verkhnekambarskoye & & & 932.95 & 18.86 \\
\hline Verkhnelem'inskoye & 36.83 & 13.59 & & \\
\hline Verkhnepurpeyskoye & 201.17 & 100.18 & 330.67 & \\
\hline Verkhnesalymskoye & 400.07 & 130.31 & & \\
\hline Verkhneshapshinskoye & 62.34 & 23.13 & & \\
\hline Verkhnesuprinskoye & 2.00 & 1.00 & & \\
\hline Verkhnetarskoye & 49.06 & 29.59 & & \\
\hline Verkhnetiuteyskoye & & & 751.10 & \\
\hline Verkhniy Kazymskoye & 32.42 & 10.89 & & \\
\hline Verkhniy Kazymskoye & 23.28 & 7.40 & & \\
\hline Verkhnyaya Kondaskoye & & & 146.14 & 1.61 \\
\hline Vershinnoye & 9.94 & 3.35 & & \\
\hline Veselovskoye & & & 18.03 & 0.29 \\
\hline Vesennee & 9.63 & 2.77 & & \\
\hline Vesenneye Zapadnoye & 11.12 & 9.82 & & \\
\hline Vladigorskoye Yuzhnoye & 24.55 & 7.82 & & \\
\hline Vonterskoye & 80.62 & 122.22 & & \\
\hline Vostochnoye(Novosibirsk) & 31.90 & 28.17 & & \\
\hline Vyintoyskoye & 94.26 & 27.32 & & \\
\hline Vyintoyskoye Vostochnoye & 21.41 & 6.81 & & \\
\hline Vyintoyskoye Yuzhnoye & 1.53 & 0.49 & & \\
\hline XXVII CPSU Congress & 160.06 & 50.94 & & \\
\hline Yagunskoye & 142.73 & 45.45 & & \\
\hline Yagunskoye Severnoye & 21.92 & 6.98 & & \\
\hline Yagunskoye Vostochnoye & 18.94 & 5.82 & & \\
\hline Yagunskoye Yuzhnoye & 1151.14 & 320.71 & & \\
\hline Yagyl'yakh & 11.12 & 9.82 & & \\
\hline Yakhlaskoye & 509.74 & 238.08 & & \\
\hline
\end{tabular}


Table 2D. Calculated Crude Oil, Natural Gas, and Condensate Recovery by Field, West Siberian Basin (Sorted Alphabetically by Field Name) (Continued)

\begin{tabular}{|c|c|c|c|c|}
\hline Field Name & $\begin{array}{l}\text { Ultimate } \\
\text { Crude Oil } \\
\text { (million } \\
\text { barrels) } \\
\end{array}$ & $\begin{array}{l}\text { Associated- } \\
\text { Disolved Gas } \\
\text { (billion } \\
\text { cubic feet) }\end{array}$ & $\begin{array}{l}\text { Nonassociated } \\
\text { Gas } \\
\text { (billion } \\
\text { cubic feet) } \\
\end{array}$ & $\begin{array}{l}\text { Condensate } \\
\text { (million } \\
\text { barrels) }\end{array}$ \\
\hline Yakhturskoye Severnoye & 7.55 & 4.14 & & \\
\hline Yamburgskoye & & & 117806.60 & 432.63 \\
\hline Yamskoye & 2.00 & 1.00 & & \\
\hline Yamsovey & & & 9937.19 & 22.51 \\
\hline Yangtaskoye Severnaya & 135.82 & 32.48 & & \\
\hline Yaraynerskoye & 323.58 & 167.74 & & \\
\hline Yaraynerskoye Severnoye & 8.19 & 18.80 & & \\
\hline Yaraynerskoye Vostochnoye & 13.12 & 30.10 & & \\
\hline Yaraynerskoye Yuzhnoye & 18.36 & 8.01 & & \\
\hline Yareyskoye & & & 138.81 & \\
\hline Yarovoye & & & 241.86 & \\
\hline Yaroyakhaskoye & & & 7271.16 & 254.49 \\
\hline Yaunlorskoye & 820.12 & 225.96 & 8.09 & 0.15 \\
\hline Yefremovoskoye & 95.66 & 27.26 & & \\
\hline Yegur'yakhskoye & 20.17 & 7.93 & & \\
\hline Yegur'yakhskoye Severnoye & 2.56 & 1.02 & & \\
\hline Yegur'yakhskoye Yuzhnoye & 61.79 & 26.20 & & \\
\hline Yelizarovskoye (Krasnoleninskoye) & 39.83 & 10.32 & & \\
\hline Yelleyskoye (Yelley) & 0.56 & 0.21 & & \\
\hline Yelovoye Vostochnoye & 62.70 & 19.96 & & \\
\hline Yemyegovskoye(Krasnoleninskoye) & 44.33 & 13.87 & & \\
\hline Yendryskoye & 211.45 & 78.03 & & \\
\hline Yenyakhaskoye & 270.37 & 134.64 & 1268.31 & \\
\hline Yermakovo & 993.86 & 275.74 & & \\
\hline Yermakovo Severnoye & 24.55 & 7.81 & & \\
\hline Yershovskoye (Tyumen) & 159.56 & 51.93 & & \\
\hline Yesetinskoye & 7.55 & 4.19 & & \\
\hline Yesetinskoye Severnoye & 7.55 & 4.14 & & \\
\hline Yetypurskoye & 143.62 & 94.44 & 4686.52 & \\
\hline Yevo-Yakhaskoye & & & 184.04 & \\
\hline Yubileynoye (Tyumen) & 115.94 & 57.74 & 6903.56 & \\
\hline Yubileynoye Vostochnoye & & & 314.43 & \\
\hline Yuganskskoye & 24.55 & 7.81 & & \\
\hline Yumantyl'skoye & 64.36 & 57.67 & & \\
\hline Yur'yevskoye Severnoye & 474.39 & 155.82 & & \\
\hline Yurkharovskoye & & & 5491.03 & 5.50 \\
\hline Yutymskoye Severnoye & 2.00 & 1.00 & & \\
\hline Yutyrmalskoye & & & 311.54 & 3.43 \\
\hline Yuzhnoye-1 & 289.91 & 144.11 & & \\
\hline Yuzhnoye-2 & 57.09 & 18.17 & & \\
\hline Zaozernoye & 383.48 & 127.70 & & \\
\hline Zapolyarnoye & & & 78082.95 & 650.24 \\
\hline Zapolyarnoye Zapadnoye & & & 871.55 & \\
\hline Zimneyeskoye & & & 446.99 & 0.63 \\
\hline Total & 161136.58 & 73220.33 & 1033227.14 & 5017.26 \\
\hline
\end{tabular}

Note: Alternate field names or field combinat ons in parenthesis. Source: Energy information Administration, Ciffice of Oil and Gas 
Table 3D. Basic Field Information, Yamal Region, West Siberian Basin (Sorted Alphabetically by Field Name)

\begin{tabular}{lccccc}
\hline Field Name & $\begin{array}{c}\text { North } \\
\text { Latitude } \\
\text { (degrees) }\end{array}$ & $\begin{array}{c}\text { East } \\
\text { Latitude } \\
\text { (degrees) }\end{array}$ & $\begin{array}{c}\text { Discovery } \\
\text { Date }\end{array}$ & $\begin{array}{c}\text { Producing } \\
\text { Status }\end{array}$ & $\begin{array}{c}\text { Primary } \\
\text { Product }\end{array}$ \\
\hline Arkticheskoye & 69.74 & 70.74 & 1968 & DV & Gas \\
Baydaratskoye & 69.72 & 67.94 & 1987 & SI & Gas \\
Bol'shoye Kruzenshternskoye & 70.00 & 69.00 & 1976 & DV & Gas \\
(Kruzenshternskoye) & 70.40 & 68.50 & 1971 & PP & Gas \\
Bovanenko & 70.83 & 68.12 & 1988 & SI & Gas \\
Bovanenko Severnoye & 70.73 & 69.22 & 1983 & SI & Gas \\
Bovanenko Vostochnoye & 68.41 & 73.34 & 1981 & DV & Gas \\
Kamennomyskoye & 71.15 & 67.12 & 1974 & PP & Gas \\
Kharasaveyskoye & 70.60 & 67.20 & 1980 & SI & Gas \\
Kruzenshternskoye Yuzhnoye & 65.50 & 72.20 & 1990 & SI & Gas \\
Leningradskoye & 68.32 & 71.60 & 1975 & DV & Gas \\
Maloyamalskoye(Lesser Yamal) & 72.20 & 70.44 & 1979 & PP & Gas \\
Malyginskoye & 70.20 & 68.50 & & SI & Gas \\
Nerstinskoye & 70.06 & 70.16 & 1975 & DV & Gas \\
Ney-To (Neytinskoye) & 67.88 & 72.43 & 1964 & DV & Gas \\
Novoportovskoye & 68.77 & 71.77 & 1970 & SI & Gas \\
Nurminskoye & 68.43 & 72.40 & 1986 & DV & Gas \\
Rostovtsevskoye & 73.40 & 65.50 & 1989 & SI & Gas \\
Rusanovskoye & 70.85 & 70.86 & 1989 & SI & Gas \\
Seyakhinskoye Zapadnoye & 69.06 & 71.16 & 1970 & DV & Gas \\
Sredneyamalskoye & 71.60 & 69.16 & 1982 & SI & Gas \\
Syadorskoye (Syadorakha) & 71.83 & 71.55 & 1982 & SI & Gas \\
Tambeyskoye Severnoye & 71.21 & 71.95 & 1974 & DV & Gas \\
Tambeyskoye Yuzhnoye & 71.54 & 70.97 & 1985 & SI & Gas \\
Tambeyskoye Zapadnoye & 71.98 & 72.01 & 1988 & SI & Gas \\
Tasiyskoye & 68.86 & 70.07 & 1989 & SI & Gas \\
Ust-Yuribeyskoye & 70.77 & 69.89 & 1982 & SI & Gas \\
Verkhnetiuteyskoye & & & & &
\end{tabular}

Notes: PP=Producing Primary, PS=Producing Secondary, DV=Developing, Sl=Shut In, ABND=Abandoned. Alternate field names or combinations in parenthesis.

Source: Energy information Administration, Office of Oil and Gas. 
Table 4D. Calculated Crude Oil, Natural Gas, and Condensate Recovery by Field, Yamal Region, West Siberian Basin (Sorted Alphabetically by Field Name)

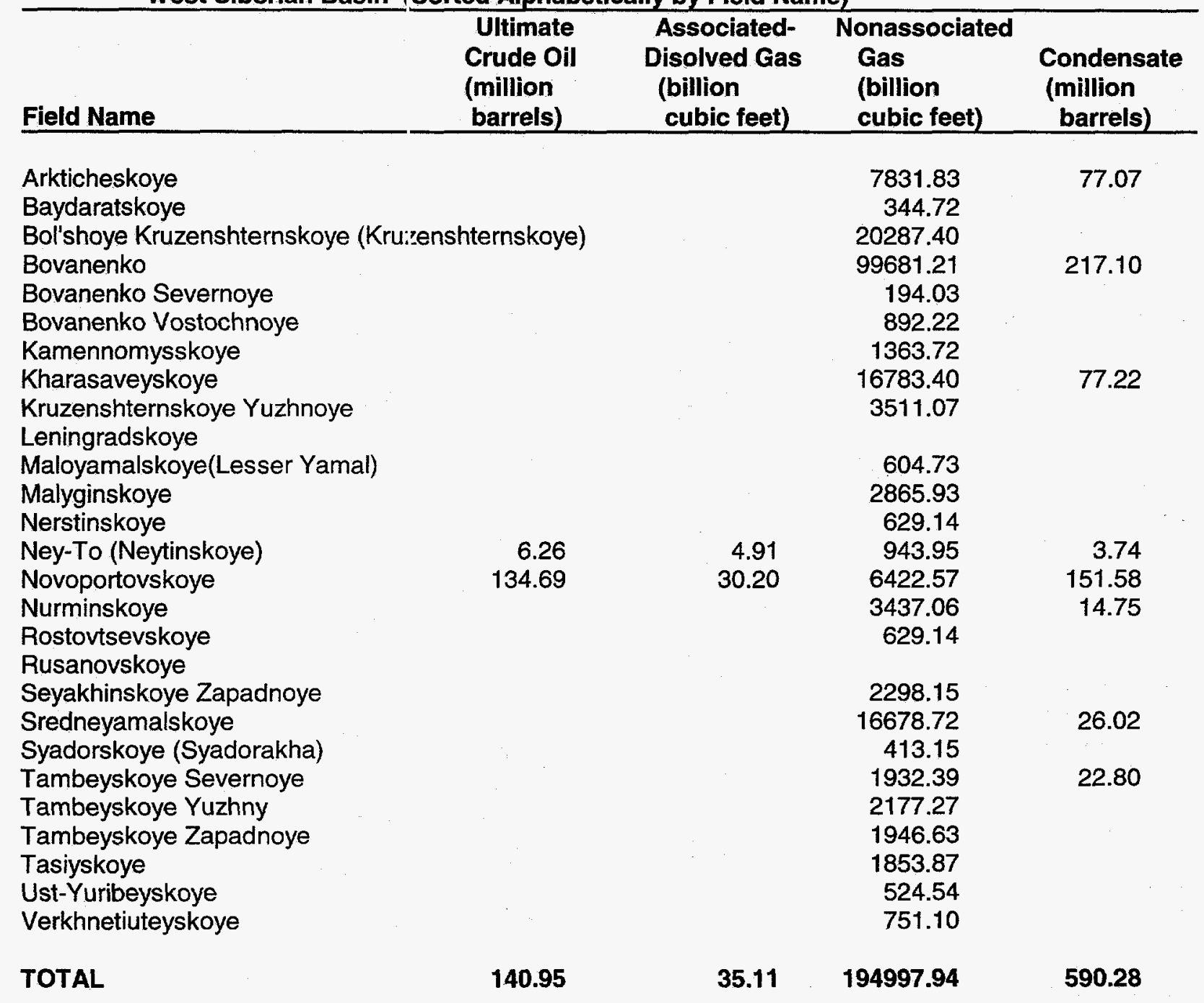

Notes: Alternate field names or combinat ons in parenthesis.

Source: Energy Information Administration, Office of Oil and Gas. 
Table 5D. Basic Field Information, Gydan Region, West Siberian Basin (Sorted Alphabetically by Field Name)

\begin{tabular}{|c|c|c|c|c|c|}
\hline Field Name & $\begin{array}{l}\text { North } \\
\text { Latitude } \\
\text { (degrees) }\end{array}$ & $\begin{array}{l}\text { East } \\
\text { Latitude } \\
\text { (degrees) }\end{array}$ & $\begin{array}{c}\text { Discovery } \\
\text { Date }\end{array}$ & $\begin{array}{l}\text { Producing } \\
\text { Status }\end{array}$ & $\begin{array}{l}\text { Primary } \\
\text { Product }\end{array}$ \\
\hline Antipayutaskoye & 68.93 & 77.38 & 1978 & SI & Gas \\
\hline Bugornaya-Vostochnaya & 69.60 & 74.60 & 1990 & S! & Gas \\
\hline Em-Yakhtinskoye & 68.83 & 76.45 & 1976 & SI & GC \\
\hline Geofizicheskoye & 69.86 & 73.69 & 1975 & SI & Gas \\
\hline Gydanskoye & 70.44 & 76.30 & 1978 & SI & Gas \\
\hline Kazantsevskoye(UstYenisey) & 69.70 & 83.30 & 1969 & SI & Gas \\
\hline Khambateyskoye & 68.77 & 72.90 & 1987 & SI & Gas \\
\hline Messoyakhaskoye Yuzhnoye & 68.06 & 79.40 & 1986 & Sl & Gas \\
\hline Messoyakhaskoye Zapadnoye & 68.50 & 79.12 & 1982 & SI & Oil \\
\hline \multicolumn{6}{|l|}{ Messoyakhskoye (Norilisk City1970) } \\
\hline (Yenisey-Khatanga) & 69.20 & 82.40 & 1967 & PP. & Gas \\
\hline Minkhovskoye & 69.37 & 76.02 & 1989 & SI & Gas \\
\hline Minkhovskoye Vostochnoye & 69.37 & 76.02 & 1991 & Sl & Gas \\
\hline \multicolumn{6}{|l|}{ Nizhne Khetskoye } \\
\hline (Yenisey-Khatanga) & 69.50 & 84.50 & 1966 & ABND & Gas \\
\hline Parusovoye & 68.44 & 74.67 & 1985 & PP & Oil \\
\hline Pelyatkinskoye (Yenisey-Khatanga) & 69.60 & 81.80 & 1977 & DV & Gas \\
\hline Semakovskoye-Anderpayuta & 68.90 & 75.53 & 1971 & SI & Gas \\
\hline Soleninskoye Severnoye(UstYenisey) & 69.24 & 81.48 & 1971 & PP & Gas \\
\hline Soleninskoye Yuzhno (Ust Yenisey) & 69.10 & 81.70 & 1969 & PP & Gas \\
\hline Soletskoye & 69.72 & 75.21 & 1984 & SI & Gas \\
\hline Totayakhinskoye & 69.14 & 76.52 & 1984 & DV & Gas \\
\hline Trekhbugornoye & 69.56 & 74.39 & 1990 & SI & Gas \\
\hline Utrenneyeskoye & 70.95 & 74.63 & 1980 & DV & Gas \\
\hline Utrenneyeskoye Severnoye & 71.07 & 74.07 & 1979 & SI & Gas \\
\hline Zimneyeskoye & 69.20 & 83.70 & 1977 & DV & Gas \\
\hline
\end{tabular}

Notes: PP=Producing Primary, PS=Producing Secondary, DV=Developing, SI=Shut in, ABND=Abandoned, GC=Gas Condensate. Alternate field names or combinations in parenthesis.

Source: Energy information Administration, Office of Oil and Gas. 
Table 6D. Calculated Crude Oil, Natural Gas, and Condensate Recovery by Field, Gydan Region, West Siberian Basin (Sorted Alphabetically by Field Name)

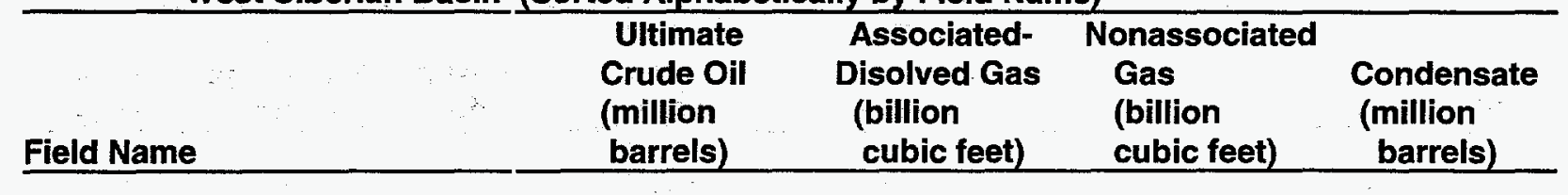

Antipayutaskoye

12294.01

$\begin{array}{ll}\text { Bugornaya-Vostochnaya } & 174.70\end{array}$

$\begin{array}{lr}\text { Em-Yakhtinskoye } & 478.28\end{array}$

$\begin{array}{lr}\text { Geofizicheskoye } & 4832.79\end{array}$

Gydanskoye

1626.86

Kazantsevskoye(UstYenisey) $\quad 409.87$

Khambateyskoye $\quad 528.42$

Messoyakhaskoye Yuzhnoye

792.63

Messoyakha Zapadnoye

211.06

165.68

Messoyakhskoye (Norilisk City1970)

(Yenisey-Khatanga)

Minkhovskoye

Minkhovskoye Vostochnoye

Nizhne Khetskoye (Yenisey-Khatanga)

Parusovoye

70.54

843.28

263.34

409.87

58.71

11.79

Pelyatkinskoye (Yenisey-Khatangél)

Semakovskoye-Anderpayuta

Soleninskoye Severnoye(UstYenis ey)

Soleninskoye Yuzhno (Ust Yenisey)

Soletskoye

Totayakhinskoye

Trekhbugornoye

Utrenneyeskoye

Utrenneyeskoye Severnoye

Zimneyeskoye

55.37

1985.80

30198.29

409.87

561.30

1893.51

1563.24

2822.40

7041.36

1783.42

446.99

12.30

26.69

281.60

221.06

71418.92

0.10

TOTAL

Notes: Alternate field names or combinetions in parenthesis.

Source: Energy Information Administration, Office of Oil and Gas. 
Table 7D. Basic Field Information, Nadym-Pur Region, West Siberian Basin (Sorted Alphabetically by Field Name)

\begin{tabular}{|c|c|c|c|c|c|}
\hline Field Name & $\begin{array}{c}\text { North } \\
\text { Latitude } \\
\text { (degrees) }\end{array}$ & $\begin{array}{c}\text { East } \\
\text { Latitude } \\
\text { (degrees) }\end{array}$ & $\begin{array}{c}\text { Discovery } \\
\text { Date }\end{array}$ & $\begin{array}{l}\text { Producing } \\
\text { Status }\end{array}$ & $\begin{array}{l}\text { Primary } \\
\text { Product }\end{array}$ \\
\hline Apakapurskoye & 63.78 & 76.44 & 1989 & $\mathrm{SI}$ & Oil \\
\hline Ayeganskoye & 61.86 & 77.42 & 1985 & PS & Oil \\
\hline \multicolumn{6}{|l|}{ Ayvasedopur Severnoye } \\
\hline (Tarasovskoye Sev.) & 64.60 & 77.67 & 1990 & SI & Oil \\
\hline Barsukovskoye & 64.42 & 75.50 & & PP & Gas \\
\hline Barsukovskoye Zapadnoye & 64.25 & 75.50 & & & Oil \\
\hline Dobrovol'skoye & 65.37 & 77.45 & 1990 & SI & Oil \\
\hline Gubkinskoye Severnoye & 65.00 & 76.70 & 1980 & SI & Oil \\
\hline \multicolumn{6}{|l|}{ Gubkinskoye (Gubkin Sev., } \\
\hline Prisklonoye) & 65.00 & 76.70 & 1965 & PP & Gas \\
\hline Izvestinskoye & 64.52 & 76.21 & 1990 & PP & Oil \\
\hline Karasevskoye (Tyumen) & 64.73 & 73.86 & 1989 & SI & Oil \\
\hline Kharvutinskoye & 67.29 & 74.18 & 1976 & PP & Oil \\
\hline Komsomol'skoye (Barsukovskoye) & 64.44 & 75.98 & 1966 & PS & Gas \\
\hline Komsomolskoye Severnoye & 64.73 & 75.35 & 1969 & PP & Gas \\
\hline Kraynyeyeskoye & 63.75 & 74.33 & 1982 & PS & Oil \\
\hline Lenzitskoye & 66.32 & 72.87 & 1984 & SI & Oil \\
\hline Malonovogodneye & 61.18 & 77.08 & 1980 & SI & Oil \\
\hline Malovar'yeganskoye & 62.20 & 77.02 & 1986 & SI & Oil \\
\hline Medvezhyeskoye & 66.23 & 74.00 & 1966 & PP & Gas \\
\hline Meretayakhaskoye & 64.61 & 74.59 & 1986 & SI & Oil \\
\hline Muravlenkoskoye & 63.99 & 74.95 & 1978 & PS & Oil \\
\hline Nadymskoye & 65.50 & 72.97 & 1972 & SI & Gas \\
\hline Nakhodkaskoye & 68.02 & 78.17 & 1974 & SI & Gas \\
\hline Neponyatnoye & 66.80 & 77.77 & 1986 & SI & Oil \\
\hline Novoaganskoye & 61.83 & 78.13 & 1985 & Sl & Oil \\
\hline Novogodneyeskoye & 63.49 & 76.92 & 1976 & PS & Oil \\
\hline Novogodneyeskoye Zapadnoye & 63.47 & 76.41 & 1987 & SI & Oil \\
\hline Novomolodezhnoye & 61.60 & 78.08 & 1977 & PS & Oil \\
\hline Novopurpeyskoye & 64.20 & 75.43 & 1983 & PS & Oil \\
\hline Nydinskoye & & & 1981 & SI & Gas \\
\hline Pangodyskoye & 65.56 & 74.53 & 1979 & SI & Gas \\
\hline Paysyataskoye & 64.30 & 73.90 & 1988 & SI & Oil \\
\hline Pestsovoye Zapadnoye & 66.91 & 74.73 & 1985 & PP & Gas \\
\hline Prisklonovoye & 65.18 & 76.97 & & & Oil \\
\hline Pulpuyakhskoye & 63.83 & 73.67 & 1977 & SI & Oil \\
\hline Purpeyskove Yuzhnove & 64.17 & 74.28 & 1984 & SI & Oil \\
\hline Purpeyskoye Zapadnoye & 64.59 & 75.54 & 1987 & PP & Oil \\
\hline Pyamaliyakhskoye Severnoye & 64.00 & 74.20 & 1982 & PS & Oil \\
\hline Pyreynoye & 65.62 & 77.69 & 1976 & DV & Gas \\
\hline Pyreynoye Yuzhnoye & 65.62 & 77.69 & 1980 & SI & Oil \\
\hline Ruch'yevskoye & 63.30 & 78.12 & 1987 & SI & Oil \\
\hline Samburgskoye Yuzhnoye(Urengoy) & 66.81 & 77.37 & 1979 & $\mathrm{SI}$ & Oil \\
\hline Samburgskoye (Urengoy) & 66.81 & 77.37 & 1975 & DV & Oil \\
\hline Sandibinskoye & 66.76 & 73.20 & 1982 & $\mathrm{PP}$ & $\mathrm{Oil}$ \\
\hline Selivonikskoye & 62.73 & 76.56 & 1988 & SI & Oil \\
\hline Sutorminskoye & 63.75 & 74.55 & 1975 & PS & Oil \\
\hline Sutorminskoye Yuzhnoye & 63.48 & 74.78 & 1988 & $\mathrm{SI}$ & Oil \\
\hline Sutorminskoye Zapadnoye & 64.00 & 74.58 & & & Oil \\
\hline Tagrinskoye & 62.32 & 78.21 & 1975 & PS & Oil \\
\hline Tanlovskoye Yuzhnoye & 64.49 & 75.20 & 1976 & PP & Oil \\
\hline
\end{tabular}


Table 7D. Basic Field Information, Nadym-Pur Region, West Siberian Basin (Sorted Alphabetically by Field Name) (Continued)

\begin{tabular}{|c|c|c|c|c|c|}
\hline Field Name & $\begin{array}{l}\text { North } \\
\text { Latitude } \\
\text { (degrees) }\end{array}$ & $\begin{array}{c}\text { East } \\
\text { Latitude } \\
\text { (degrees) }\end{array}$ & $\begin{array}{c}\text { Discovery } \\
\text { Date }\end{array}$ & $\begin{array}{l}\text { Producing } \\
\text { Status }\end{array}$ & $\begin{array}{l}\text { Primary } \\
\text { Product }\end{array}$ \\
\hline Tanusalinskoye & 66.88 & 73.80 & 1987 & SI & Gas \\
\hline Tarasovskoye (Ayvasedopurskoye) & 64.47 & 77.73 & 1967 & PS & Oil \\
\hline Tarko-Sale Vostochnoye & 65.05 & 78.10 & 1971 & DV & Gas \\
\hline Tarko-Sale Yuzhnoye & 63.97 & 78.59 & 1984 & SI & Oil \\
\hline Tarko-Sale Zapadnoye & 64.79 & 77.20 & 1972 & PP & Gas \\
\hline Tavlovskoye Yuzhnoye & 64.57 & 75.08 & & SI & Oil \\
\hline Umseyskoye & 64.08 & 74.39 & 1982 & PP & Oil \\
\hline Umseyskoye Vostochnoye & 64.19 & 74.61 & 1988 & SI & Oil \\
\hline Urengoyskoye (Pestsovoye) & 66.95 & 75.36 & 1970 & SI & Gas \\
\hline \multicolumn{6}{|c|}{$\begin{array}{l}\text { Urengoyskoye (Samburg, Yevo-Yakna, } \\
\text { Yen-Yakha, Urengoy Sev., }\end{array}$} \\
\hline Pestsovoye) & 66.05 & 76.95 & 1966 & PP & Gas \\
\hline Urengoyskoye Severnoye & 67.54 & 76.55 & 1970 & PP & Gas \\
\hline Urengoyskoye Vostochnoye & 66.08 & 77.49 & 1978 & UK & Gas \\
\hline Van'yeganskoye & 61.85 & 77.23 & 1974 & PS & Oil \\
\hline Var'yeganskoye & 62.11 & 77.57 & 1967 & PS & Oil \\
\hline Var'yeganskoye Severnoye & 62.44 & 77.40 & 1971 & PS & Oil \\
\hline Var'yeganskoye Yuzhnoye & 62.20 & 76.73 & 1982 & SI & Oil \\
\hline Var'yeganskoye Zapadnoye & 62.31 & 76.69 & 1981 & PS & Oil \\
\hline Venqapurskove & 63.09 & 76.59 & 1968 & PP & Gas \\
\hline Vengapurskoye Severnoye & 63.20 & 76.70 & 1992 & SI & Oil \\
\hline Vengapurskoye Yuzhnoye & 62.63 & 76.82 & 1973 & PP & Oil \\
\hline Vengapurskoye Zapadnoye & 63.17 & 76.35 & 1992 & Si & Oil \\
\hline Vengayakha (Vengayakha Vost.) & 63.97 & 76.90 & 1968 & PS & Gas \\
\hline Verkhnepurpey & 64.57 & 75.50 & 1976 & PP & Gas \\
\hline Yamburgskoye & 67.98 & 75.84 & 1969 & PP & Gas \\
\hline Yamsoveyskoye & 65.56 & 75.32 & 1970 & DV & Gas \\
\hline Yangtaskoye Severnaya & 64.23 & 74.94 & 1985 & Si & Oil \\
\hline Yaraynerskoye & 63.17 & 77.79 & 1973 & PP & Oil \\
\hline Yaraynerskoye Severnoye & 63.17 & 77.90 & 1987 & SI & Oil \\
\hline Yaraynerskoye Vostochnoye & 63.08 & 77.89 & 1987 & SI & Oil \\
\hline Yaraynerskoye Yuzhnoye & 62.75 & 78.01 & 1988 & SI & Oil \\
\hline Yareyskove & 65.18 & 75.85 & 1989 & SI & Gas \\
\hline Yenyakhaskoye & 67.00 & 76.50 & 1976 & SI & Oil \\
\hline Yetypurskoye & 63.95 & 77.63 & 1971 & DV & Gas \\
\hline Yevo-Yakhaskoye & 65.85 & 77.30 & 1980 & SI & Gas \\
\hline Yubileynoye (Tyumen) & 65.99 & 75.76 & 1969 & PP & Gas \\
\hline Yubileynoye Vostochnoye & 65.88 & 76.17 & 1988 & SI & Gas \\
\hline Yumantyl'skoye & 65.06 & 72.89 & 1988 & SI & Oil \\
\hline Yurkharovskoye & 67.78 & 77.08 & 1970 & SI & Gas \\
\hline
\end{tabular}

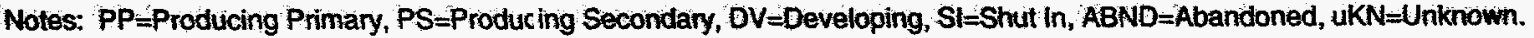
Altemate field names or combinations in pare nthesis.

Source: Energy information Administration, Office of Oil and Gas. 
Table 8D. Calculated Crude Oil, Natural Gas, and Condensate Recovery by Field, Nadym-Pur Region, West Siberian Basin (Sorted Alphabetically by Field Name)

\begin{tabular}{|c|c|c|c|c|}
\hline Field Name & $\begin{array}{l}\text { Ultimate } \\
\text { Crude Oil } \\
\text { (million } \\
\text { barrels) } \\
\end{array}$ & $\begin{array}{l}\text { Associated- } \\
\text { Disolved Gas } \\
\text { (billion } \\
\text { cubic feet) }\end{array}$ & $\begin{array}{l}\text { Nonassociated } \\
\text { Gas } \\
\text { (billion } \\
\text { cubic feet) } \\
\end{array}$ & $\begin{array}{c}\text { Condensate } \\
\text { (million } \\
\text { barrels) }\end{array}$ \\
\hline Apakapurskoye & 80.93 & 63.53 & & \\
\hline Ayeganskoye & 33.74 & 22.82 & & \\
\hline Ayvasedopur Severnoye & & & & \\
\hline (Tarasovskoye Sev.) & 46.20 & 36.54 & & \\
\hline Barsukovskoye & & & $4,531.10$ & 222.02 \\
\hline Barsukovskoye Zapadnoye & 2.49 & 2.23 & & \\
\hline Dobrovol'skoye & 54.08 & 26.93 & & - \\
\hline Gubkinskoye Severnoye & 342.50 & 313.76 & 624.07 & 30.58 \\
\hline Gubkinskoye (Gubkin Sev., & & & & \\
\hline Prisklonoye) & 0.22 & 0.17 & $10,580.14$ & 0.16 \\
\hline Izvestinskoye & 64.63 & 57.91 & & \\
\hline Karasevskoye (Tyumen) & 54.30 & 48.65 & & \\
\hline Kharvutinskoye & 57.06 & 28.42 & 346.91 & \\
\hline Komsomol'skoye (Barsukovskoye) & & & $23,190.35$ & \\
\hline Komsomolskoye Severnoye & & & $4,052.30$ & 4.10 \\
\hline Kraynyeyeskoye & 165.21 & 82.28 & & \\
\hline Lenzitskoye & 163.80 & 83.87 & & \\
\hline Malonovogodneye & 4.79 & 4.29 & & \\
\hline Malovar'yeganskoye & 10.19 & 8.56 & & \\
\hline Medvezhyeskoye & 0.11 & 0.09 & $54,896.48$ & \\
\hline Meretayakhaskoye & 95.83 & 85.86 & & \\
\hline Muravlenkoskoye & 816.81 & 376.16 & $5,185.13$ & \\
\hline Nadymskoye & & & $1,227.61$ & \\
\hline Nakhodkaskoye & & & $3,857.11$ & \\
\hline Neponyatnoye & 64.57 & 57.86 & & \\
\hline Novoaganskoye & 79.67 & 71.38 & & \\
\hline Novogodneyeskoye & 143.20 & 86.94 & 100.41 & \\
\hline Novogodneyeskoye Zapadnoye & 2.95 & 2.37 & & \\
\hline Novomolodezhnoye & 232.65 & 132.71 & & \\
\hline Novopurpeyskoye & 438.01 & 154.15 & & \\
\hline Nydinskoye & & & 110.41 & \\
\hline Pangodyskoye & 170.59 & 75.75 & $1,726.22$ & \\
\hline Paysyataskoye & 161.67 & 605.94 & & \\
\hline Pestsovoye Zapadnoye & & & $2,885.48$ & \\
\hline Prisklonovoye & 32.23 & 28.88 & & \\
\hline Pulpuyakhskoye & 185.03 & 92.14 & & \\
\hline Purpeyskoye Yuzhnoye & 12.97 & 5.22 & & \\
\hline Purpeyskoye Zapadnoye & 35.85 & 32.12 & & \\
\hline Pyamaliyakhskoye Severnoye & 64.43 & 57.73 & & \\
\hline Pyreynoye & & & 77.80 & \\
\hline Pyreynoye Yuzhnoye & 342.08 & 170.35 & $1,124.35$ & \\
\hline Ruch'yevskoye & 2.76 & 1.20 & & \\
\hline Samburgskoye Yuzhnoye(Urengoy) & 157.46 & 78.42 & & \\
\hline Samburgskoye (Urengoy) & 692.04 & 344.63 & & \\
\hline Sandibinskoye & 63.30 & 29.69 & & \\
\hline Selivonikskoye & 10.54 & 6.38 & & \\
\hline Sutorminskoye & $2,479.98$ & $1,364.58$ & & \\
\hline Sutorminskoye Yuzhnoye & 24.68 & 22.11 & & \\
\hline Sutorminskoye Zapadnny & 39.13 & 19.49 & & \\
\hline
\end{tabular}


Table 8D. Calculated Crude Oil, Natural Gas, and Condensate Recovery by Field, Nadym-Pur Region, West Siberian Basin (Sorted Alphabetically by Field Name) (Continued)

\begin{tabular}{|c|c|c|c|c|}
\hline Field Name & $\begin{array}{l}\text { Ultimate } \\
\text { Crude Oil } \\
\text { (million } \\
\text { barrels) } \\
\end{array}$ & $\begin{array}{l}\text { Associated- } \\
\text { Disolved Gas } \\
\text { (billion } \\
\text { cubic feet) }\end{array}$ & $\begin{array}{l}\text { Nonassociated } \\
\text { Gas } \\
\text { (billion } \\
\text { cubic feet) } \\
\end{array}$ & $\begin{array}{c}\text { Condensate } \\
\text { (million } \\
\text { barrels) }\end{array}$ \\
\hline Tagrinskoye & 374.81 & 71.82 & & \\
\hline Tanlovskoye Yuzhnoye & 143.29 & 128.39 & & \\
\hline Tanusalinskoye & & & 331.01 & \\
\hline Tarasovskoye (Ayvasedopurskoye) & $4,117.24$ & $3,191.67$ & $2,675.57$ & 15.33 \\
\hline Tarko-Sale Vostochnoye & 422.77 & 131.68 & $4,122.40$ & 26.90 \\
\hline Tarko-Sale Yuzhnoye & 79.63 & 71.35 & & \\
\hline Tarko-Sale Zapadnoye & 80.15 & 39.92 & $2,709.00$ & \\
\hline Tavlovskoye Yuzhnoye & 129.02 & 115.60 & & \\
\hline Umseyskoye & 247.05 & 90.93 & & \\
\hline Umseyskoye Vostochnoye & 9.55 & 8.56 & & \\
\hline Urengoyskoye (Pestsovoye) & 293.56 & 230.44 & $4,955.25$ & \\
\hline \multicolumn{5}{|l|}{$\begin{array}{l}\text { Urengoyskoye (Samburg, Yevo-Yakha, } \\
\text { Yen-Yakha,Urengoy Sev., }\end{array}$} \\
\hline Pestsovoye) & $6,617.30$ & 404.15 & $269,586.82$ & $1,858.08$ \\
\hline Urengoyskoye Severnoye & & & $23,117.35$ & 41.78 \\
\hline Urengoyskoye Vostochnoye & & & $1,115.97$ & 39.06 \\
\hline Van'yeganskoye & $1,135.66$ & 457.64 & $1,264.33$ & 34.66 \\
\hline Var'yeganskoye & $2,091.55$ & $8,336.78$ & 496.21 & \\
\hline Var'yeganskoye Severnoye & $1,292.93$ & $1,699.88$ & 412.54 & 8.25 \\
\hline Var'yeganskoye Yuzhnoye & 73.70 & 61.44 & & \\
\hline Var'yeganskoye Zapadnoye & 213.47 & 112.01 & & \\
\hline Vengapurskoye & 595.91 & $1,814.72$ & $5,722.36$ & \\
\hline Vengapurskoye Severnoye & 64.39 & 57.69 & & \\
\hline Vengapurskoye Yuzhnoye & 899.51 & 365.95 & & \\
\hline Vengapurskoye Zapadnoye & 64.39 & 57.69 & & \\
\hline Vengayakha (Vengayakha Vost.) & 501.34 & 189.42 & $3,635.31$ & \\
\hline Verkhnepurpey & 201.17 & 100.18 & 330.67 & \\
\hline Yamburgskoye & & & $117,806.60$ & 432.63 \\
\hline Yamsoveyskoye & & & $9,937.19$ & 22.51 \\
\hline Yangtaskoye Severnaya & 135.82 & 32.48 & & \\
\hline Yaraynerskoye & 323.58 & 167.74 & & \\
\hline Yaraynerskoye Severnoye & 8.19 & 18.80 & & \\
\hline Yaraynerskoye Vostochnoye & 13.12 & 30.10 & & \\
\hline Yaraynerskoye Yuzhnoye & 18.36 & 8.01 & & \\
\hline Yareyskoye & & & 138.81 & \\
\hline Yenyakhaskoye & 270.37 & 134.64 & $1,268.31$ & \\
\hline Yetypurskoye & 143.62 & 94.44 & $4,686.52$ & \\
\hline Yevo-Yakhaskoye & & & 184.04 & \\
\hline Yubileynoye (Tyumen) & 115.94 & 57.74 & $6,903.56$ & \\
\hline Yubileynoye Vostochnoye & & & 314.43 & \\
\hline Yumantyl'skoye & 64.36 & 57.67 & & \\
\hline Yurkharovskoye & & & $5,491.03$ & 5.50 \\
\hline TOTAL & $28,170.44$ & $23,021,65$ & $581,721.12$ & $2,741.56$ \\
\hline
\end{tabular}

Notes: Alternate field names or combinatio 1 in parenthesis.

Source: Energy Information Administration, Office of Oil and Gas. 
Table 9D. Basic Field Information, Pur-Taz Region, West Siberian Basin (Sorted Alphabetically by Field Name)

\begin{tabular}{|c|c|c|c|c|c|}
\hline Field Name & $\begin{array}{c}\text { North } \\
\text { Latitude } \\
\text { (degrees) }\end{array}$ & $\begin{array}{c}\text { East } \\
\text { Latitude } \\
\text { (degrees) }\end{array}$ & $\begin{array}{c}\text { Discovery } \\
\text { Date }\end{array}$ & $\begin{array}{c}\text { Producing } \\
\text { Status }\end{array}$ & $\begin{array}{l}\text { Primary } \\
\text { Product }\end{array}$ \\
\hline Bakhilovskoye & 62.47 & 79.65 & 1983 & PS & Oil \\
\hline Beregovoye & 65.87 & 78.97 & 1982 & SI & Gas \\
\hline Chaselskoye Severnoye & 66.04 & 79.33 & 1987 & SI & Gas \\
\hline Chatylkynskoye & 63.44 & 80.99 & 1989 & SI & Oil \\
\hline Chernichnoye & 65.54 & 81.97 & 1985 & $\mathrm{SI}$ & Oil \\
\hline Festivalnoye (Tyumen)(Kamy) & 63.73 & 79.48 & 1985 & DV & Oil \\
\hline Gaz-Sale & 67.40 & 80.43 & 1989 & SI & Gas \\
\hline lokhturskoye Severnoye & 63.72 & 79.14 & 1987 & SI & Oil \\
\hline Khadyryakhaskoy & 65.30 & 79.53 & 1989 & $\mathrm{SI}$ & Gas \\
\hline Khadyryakhaskoye Yuzhnaya & 65.03 & 79.98 & 1990 & SI & Oil \\
\hline Khalmerpayutaskoye & 67.75 & 81.15 & 1989 & SI & Gas \\
\hline Khancheyskoye (or Khangey) & 64.82 & 79.41 & 1990 & SI & Gas \\
\hline Kharam-Pur Yuzhnoye & 63.85 & 79.87 & 1981 & SI & Gas \\
\hline Kharampur (Kharampur Yuz.) & 64.22 & 79.65 & 1978 & PS & Oil \\
\hline Kharampur Zapadnoye & 64.17 & 78.92 & 1987 & SI & Oil \\
\hline Khay-Yakhinskoy & 66.27 & 77.67 & & SI & Oil \\
\hline Kholmistoye & 63.26 & 80.11 & 1988 & SI & Oil \\
\hline Kynskoye & 65.15 & 80.58 & 1982 & $\mathrm{SI}$ & Oil \\
\hline Limbayakhaskoye & 67.20 & 80.40 & 1991 & $\mathrm{SI}$ & Oil \\
\hline Mangazeyskoye & 66.80 & 82.67 & 1987 & SI & Oil \\
\hline Messoyakhaskoye Vostochnaya & 68.60 & 80.12 & 1989 & SI & Oil \\
\hline Novochaselskoye & 65.42 & 80.17 & 1989 & SI & Oil \\
\hline Perekatnoye & 67.74 & 78.69 & 1988 & SI & Gas \\
\hline Purovskoye Severnoye & 66.54 & 78.33 & 1986 & SI & Gas \\
\hline Pyakyakhinskoye & 67.84 & 80.13 & 1989 & SI & Gas \\
\hline Ravninnoye & 63.33 & 79.52 & 1987 & SI & Oil \\
\hline Russkorechenskoye & 67.14 & 81.82 & 1985 & SI & Oil \\
\hline Russkoye & 66.75 & 80.44 & 1968 & DV & Oil \\
\hline Russkoye Yuzhnoye & 65.93 & 80.38 & 1969 & DV & Gas \\
\hline Salekaptskoye & 67.50 & 78.30 & 1986 & SI & Oil \\
\hline Srede-Kharampur & 64.10 & 73.63 & & SI & Oil \\
\hline Stakhanovskoye & 63.41 & 78.52 & 1988 & SI & Oil \\
\hline Stakhanovskoye Severnoye & & & & SI & Oil \\
\hline Suzunskoye & 68.34 & 83.60 & 1971 & SI & Oil \\
\hline Tagul'skoye & 67.75 & 82.78 & 1988 & SI & Oil \\
\hline Tapskoye & 64.58 & 78.82 & 1986 & SI & Oil \\
\hline Tazskoye & 67.39 & 78.92 & 1962 & PP & Oil \\
\hline Tazovskoye Vostochnoye & 67.32 & 79.63 & 1980 & SI & Gas \\
\hline Tekto-Kharampur & 63.87 & 79.83 & 1990 & SI & Oil \\
\hline Terel'skoye & 64.38 & 80.04 & 1986 & SI & Gas \\
\hline Termokarstovoye & 65.43 & 82.54 & 1988 & SI & Gas \\
\hline Tolkinskoye & 64.33 & 82.28 & 1989 & SI & GC \\
\hline Ust Chaselskoye & 65.12 & 81.10 & 1981 & SI & Oil \\
\hline Ust Kharampur & 64.30 & 78.19 & 1983 & PP & Oil \\
\hline Verkhne Chasel'kaskoye & 65.20 & 80.40 & 1980 & SI & Oil \\
\hline Verkhne-Kolikyeganskoye & 62.42 & 80.15 & 1981 & PS & Oil \\
\hline Yakhturskoye Severnoye & 63.75 & 79.00 & & SI & Oil \\
\hline Yarovoye & 66.00 & 79.50 & 1991 & SI & Gas \\
\hline Yaroyakhaskoye & 66.23 & 78.75 & 1984 & PP & Gas \\
\hline Yesetinskoye & 66.42 & 77.58 & & SI & Oil \\
\hline Yesetinskoye Severnoye & 66.50 & 77.50 & & SI & Oil \\
\hline
\end{tabular}


Table 9D. Basic Field Information, Pur-Taz Region, West Siberian Basin (Sorted Alphabetically by Field Name) (Continued)

\begin{tabular}{llllll}
\hline Field Name & $\begin{array}{c}\text { North } \\
\text { Latitude } \\
\text { (degrees) }\end{array}$ & $\begin{array}{c}\text { East } \\
\text { Latitude } \\
\text { (degrees) }\end{array}$ & $\begin{array}{c}\text { Discovery } \\
\text { Date }\end{array}$ & $\begin{array}{c}\text { Producing } \\
\text { Status }\end{array}$ & $\begin{array}{c}\text { Primary } \\
\text { Product }\end{array}$ \\
\hline & & & & & \\
Yutyrmalskoye & 64.82 & 81.41 & 1988 & $\mathrm{SI}$ & Gas \\
Zapolyarnoye & 66.87 & 79.63 & 1965 & $\mathrm{DV}$ & Gas \\
Zapolyarnoye Zapadnoye & 66.70 & 78.78 & 1979 & $\mathrm{SI}$ & Gas
\end{tabular}

Notes: PP=Producing Primary, PS=Producing Secondary, DV=Developing, Sl=Shut in, $A B N D=A b a n d o n e d$. Alternate field names or combined field names in parenthesis.

Source: Energy information Administration Office of Oil and Gas. 
Table 10D. Calculated Crude Oil, Natural Gas, and Condensate Recovery by Field, Pur-Taz Region, West Siberian Basin (Sorted Alphabetically by Field Name)

\begin{tabular}{|c|c|c|c|c|}
\hline Field Name & $\begin{array}{l}\text { Ultimate } \\
\text { Crude Oil } \\
\text { (million } \\
\text { barrels) } \\
\end{array}$ & $\begin{array}{l}\text { Associated- } \\
\text { Disolved Gas } \\
\text { (billion } \\
\text { cubic feet) }\end{array}$ & $\begin{array}{l}\text { Nonassociated } \\
\text { Gas } \\
\text { (billion } \\
\text { cubic feet) } \\
\end{array}$ & $\begin{array}{c}\text { Condensate } \\
\text { (million } \\
\text { barrels) }\end{array}$ \\
\hline Bakhilovskoye & & & 315.72 & 178.49 \\
\hline $\begin{array}{l}\text { Beregovoye } \\
\text { Chaselskoye Severnoye }\end{array}$ & 130.13 & 102.15 & $\begin{array}{r}5,777.28 \\
241.86\end{array}$ & \\
\hline Chatylkynskoye & 52.51 & 29.57 & & \\
\hline Chernichnoye & 26.91 & 15.25 & & \\
\hline Festivalnoye (Tyumen)(Kamy) & 40.16 & 8.83 & & \\
\hline Gaz-Sale & & & 257.34 & 9.01 \\
\hline lokhturskoye Severnoye & 22.67 & 12.84 & & \\
\hline Khadyryakhaskoye & & & 434.66 & \\
\hline Khadyryakhaskoye Yuzhnaya & 15.31 & 12.02 & & \\
\hline Khalmerpayutaskoye & & & 106.76 & \\
\hline Khancheyskoye (or Khangey) & & & 98.62 & 1.13 \\
\hline Kharam-Pur Yuzhnoye & 97.67 & 103.54 & $3,080.19$ & \\
\hline Kharampur (Kharampur Yuz.) & 634.43 & 485.37 & $17,927.84$ & 14.82 \\
\hline Kharampur Zapadnoye & 32.94 & 18.66 & & \\
\hline Khay-Yakhinskoye & 7.55 & 4.16 & & \\
\hline Kholmistoye & 23.73 & 8.56 & & \\
\hline Kynskoye & & & 55.40 & \\
\hline Limbayakhaskoye & 42.13 & 23.78 & & \\
\hline Mangazeyskoye & 45.18 & 14.64 & & \\
\hline Messoyakhaskoye Vostochnaya & 179.01 & 21.66 & 495.65 & \\
\hline Novochaselskoye & 260.28 & 146.90 & & \\
\hline Perekatnoye & & & 211.90 & \\
\hline Purovskoye Severnoye & & & 923.65 & \\
\hline Pyakyakhinskoye & & & $1,494.14$ & \\
\hline Ravninnoye & 66.25 & 37.39 & & \\
\hline Russkorechenskoye & 123.04 & 69.44 & & \\
\hline Russkoye & $2,702.07$ & 402.61 & $2,804.31$ & \\
\hline Russkoye Yuzhnoye & & & $16,121.27$ & \\
\hline Salekaptskoye & 189.29 & 106.84 & & \\
\hline Srede-Kharampur & 7.55 & 4.14 & & \\
\hline Stakhanovskoye & 661.27 & 243.96 & & \\
\hline Stakhanovskoye Severnoye & 42.13 & 23.78 & & \\
\hline Suzunskoye & 389.37 & 193.90 & $2,424.70$ & \\
\hline Tagul'skoye & 95.64 & 17.79 & & \\
\hline Tapskoye & 109.22 & 60.90 & & \\
\hline Tazskoye & 462.50 & 363.06 & $4,278.68$ & 50.49 \\
\hline Tazovskoye Vostochnoye & & & $2,603.30$ & \\
\hline Tekto-Kharampur & 2.00 & 1.00 & & \\
\hline Terel'skoy & & & 869.32 & \\
\hline Termokarstovoye & & & 918.46 & 45.00 \\
\hline Tolkinskoye & & & 364.13 & 8.74 \\
\hline Ust Chaselskoye & 211.21 & 105.18 & 394.35 & 15.40 \\
\hline Ust Kharampur & 52.60 & 28.82 & & \\
\hline Verkhne Chasel'kaskoye & 13.04 & 10.23 & & \\
\hline Verkhne-Kolikyeganskoye & $4,896.64$ & $3,040.00$ & $3,615.02$ & 4.49 \\
\hline Yakhturskoye Severnoye & 7.55 & 4.14 & & \\
\hline Yarovoye & & & 241.86 & \\
\hline Yaroyakhaskoye & & & $7,271.16$ & 254.49 \\
\hline Yesetinskoye & 7.55 & 4.19 & & \\
\hline
\end{tabular}


Table 10D. Calculated Crude Oil, Natural Gas, and Condensate Recovery by Field, Pur-Taz Region, West Siberian Basin (Sorted Alphabetically by Field Name) (Continued)

\begin{tabular}{lcccc}
\hline & $\begin{array}{c}\text { Ultimate } \\
\text { Crude Oil } \\
\text { (million } \\
\text { barrels) }\end{array}$ & $\begin{array}{c}\text { Associated- } \\
\text { Disolved Gas } \\
\text { (billion } \\
\text { cubic feet) }\end{array}$ & $\begin{array}{c}\text { Nonassociated } \\
\text { Gas } \\
\text { (billion } \\
\text { cubic feet) }\end{array}$ & $\begin{array}{c}\text { Condensate } \\
\text { (million } \\
\text { barrels) }\end{array}$ \\
\hline $\begin{array}{l}\text { Yesetinskoye Severnoye } \\
\text { Yutyrmalskoye }\end{array}$ & 7.55 & 4.14 & & \\
$\begin{array}{l}\text { Zapolyarnoye } \\
\text { Zapolyarnoye Zapadnoye }\end{array}$ & & & 311.54 & 3.43 \\
Total & & & $78,082.95$ & 650.24 \\
& $11,972.80$ & $5,907.93$ & $\mathbf{1 5 2 , 2 7 7 . 8 9}$ & $\mathbf{1 , 0 5 7 . 2 3}$
\end{tabular}

Notes: Alternate field names or combinations in parenthesis.

Source: Energy Information Administration Office of Oil and Gas. 
Table 11D. Basic Field Information, Frolov Region, West Siberian Basin (Sorted Alphabetically by Field Name)

\begin{tabular}{|c|c|c|c|c|c|}
\hline Field Name & $\begin{array}{c}\text { North } \\
\text { Latitude } \\
\text { (degrees) }\end{array}$ & $\begin{array}{l}\text { East } \\
\text { Latitude } \\
\text { (degrees) }\end{array}$ & $\begin{array}{c}\text { Discovery } \\
\text { Date }\end{array}$ & $\begin{array}{l}\text { Producing } \\
\text { Status }\end{array}$ & $\begin{array}{l}\text { Primary } \\
\text { Product }\end{array}$ \\
\hline Aprel'skoye & 62.38 & 68.63 & 1982 & SI & Oil \\
\hline Bol'shoye & 62.90 & 67.27 & 1984 & SI & Oil \\
\hline Dekabr'skoye & 62.02 & 70.25 & 1969 & sI & Oil \\
\hline Erginskoye & 60.70 & 69.29 & 1983 & SI & Oil \\
\hline Erginskoye Vostochnoye & 60.69 & 69.82 & 1988 & SI & Oil \\
\hline Frolovskove Vostochnove & 60.90 & 69.81 & 1987 & SI & Oil \\
\hline Galleyskoye & 61.77 & 66.27 & & & Oil \\
\hline Galyanovskoye & 61.50 & 68.29 & 1982 & SI & Oil \\
\hline Gorshkovskoye Zapadnoye & 61.62 & 70.19 & 1988 & SI & Oil \\
\hline Ingaskoye (Inginsk)(Krasnoleninskoye) & e) 61.57 & 66.57 & 1975 & SI & Oil \\
\hline It'yakhskoye & 62.30 & 68.97 & 1992 & SI & Oil \\
\hline Krasnoleninskoye & 61.65 & 67.32 & 1962 & PS & Oil \\
\hline Karempostskoye & 62.18 & 66.18 & 1986 & SI & Oil \\
\hline Kazymskoye Severnoye & 63.98 & 67.41 & 1965 & SI & Gas \\
\hline Khanty-Mansiyskoye (Tsentralnoye) & 61.04 & 69.21 & 1986 & Si & Oil \\
\hline Kislorskoye & 63.65 & 66.55 & 1993 & SI & Oil \\
\hline Krasnoleninskoye & 61.70 & 66.77 & 1962 & PS & Oil \\
\hline Lebyazhyeskoye & 61.98 & 66.91 & 1981 & SI & Oil \\
\hline Lorbinskoye & 61.52 & 67.83 & 1966 & PS & Oil \\
\hline Lykhminskoye & 63.25 & 65.82 & 1982 & si & Oil \\
\hline Malopriobskoye & & & & & Oil \\
\hline Nazymskoye & 62.48 & 67.89 & 1988 & SI & Oil \\
\hline Novoyendyrskoye & 61.85 & 67.87 & 1977 & SI & Oil \\
\hline Ol'khovskoye (Tyumen) & 63.20 & 67.86 & 1986 & $\mathrm{SI}$ & Oil \\
\hline Ontokhskoye & 60.81 & 66.15 & 1989 & SI & Oil \\
\hline Palyanovskoye & 61.75 & 65.92 & 1972 & PP & Oil \\
\hline Paytykhskoye & 61.26 & 65.37 & 1987 & SI & Oil \\
\hline Peschanoye & 62.23 & 65.95 & 1987 & SI & Oil \\
\hline Pottymskoye & 61.22 & 66.99 & 1988 & Sl & Oil \\
\hline Priobskoye & 61.13 & 70.46 & 1982 & PS & Oil \\
\hline Priobskoye Severnoye & 61.56 & 70.50 & 1988 & SI & Oil \\
\hline Priobskoye Zapadnove & 61.59 & 70.37 & 1988 & SI & Oil \\
\hline Prirakhtovskoye & 57.36 & 72.21 & 1975 & SI & Oil \\
\hline Rogozhnikovskoye & 62.21 & 67.29 & 1988 & SI & Oil \\
\hline Rogozhnikovskoye Severnoye & 62.30 & 67.20 & 1990 & SI & Oil \\
\hline Rogozhnikovskoye Yuzhnoye & 62.10 & 67.50 & 1990 & SI & Oil \\
\hline Rogozhnikovskoye Zapadnoye & 62.20 & 67.20 & & SI & Oil \\
\hline Seliyarovskoye & 61.50 & 70.17 & & SI & Oil \\
\hline Seliyarovskoye Severnoye & 61.81 & 69.49 & 1988 & SI & Oil \\
\hline Sheburskoye Vostochnoye & 60.32 & 66.98 & 1990 & SI & Oil \\
\hline Sosnovomysskoye (Krasnoleninskoye) & 62.06 & 66.41 & 1975 & SI & Oil \\
\hline Sote-Yuganskoye Severnoye & 62.30 & 64.50 & 1963 & PP & Gas \\
\hline Sote-Yuganskoye Yuzhnoye & 62.19 & 64.55 & 1964 & PP & Gas \\
\hline Sote-Yuganskoye & 62.25 & 64.50 & 1963 & SI & Gas \\
\hline Srednenazymskoye & 61.95 & 68.34 & 1978 & SI & Oil \\
\hline Sredniy Lykhmskoye & 63.51 & 66.44 & 1982 & SI & Oil \\
\hline Srednenazymskoye & 61.98 & 68.35 & 1978 & SI & Oil \\
\hline Syn'yeganskoye & 61.65 & 69.45 & 1984 & SI & Oil \\
\hline Talinskoye & 62.00 & 66.55 & & SI & Oil \\
\hline Talinskoye Zapadnoye & 62.00 & 66.50 & 1992 & SI & Oil \\
\hline Taytymskoye & 57.96 & 73.45 & 1975 & SI & Oil \\
\hline
\end{tabular}


Table 11D. Basic Field Informaticn, Frolov Region, West Siberian Basin (Sorted Alphabetically by Field Name) (Continued)

\begin{tabular}{lccccc}
\hline Field Name & $\begin{array}{c}\text { North } \\
\text { Latitude } \\
\text { (degrees) }\end{array}$ & $\begin{array}{c}\text { East } \\
\text { Latitude } \\
\text { (degrees) }\end{array}$ & $\begin{array}{c}\text { Discovery } \\
\text { Date }\end{array}$ & $\begin{array}{c}\text { Producing } \\
\text { Status }\end{array}$ & $\begin{array}{c}\text { Primary } \\
\text { Product }\end{array}$ \\
\hline Tevrizskoye & 57.55 & 72.29 & 1971 & $\mathrm{SI}$ & Gas \\
Tevrizskoye Vostochnoye & 57.52 & 72.30 & & $\mathrm{SI}$ & Gas \\
Tortasinskoye & 62.19 & 69.59 & 1989 & $\mathrm{SI}$ & Oil \\
Tsentralnoye (Khanty-Mansiyskoye) & 62.62 & 67.55 & 1987 & $\mathrm{SI}$ & Oil \\
Tugrovskoye Severnoye & 61.88 & 64.75 & 1992 & $\mathrm{SI}$ & Oil \\
Tugrovskoye Vostochnoye & 61.70 & 64.80 & 1989 & $\mathrm{SI}$ & Gas \\
Tugrovskoye Zapadnoye & & & & $\mathrm{SI}$ & Oil \\
Tumannoye & 61.85 & 70.38 & 1974 & $\mathrm{SI}$ & Oil \\
Tunkorskoye & 62.36 & 68.30 & 1989 & $\mathrm{SI}$ & Oil \\
Verkhne-Lyaminskoye (Upper Lyamia) & 62.15 & 70.54 & 1970 & $\mathrm{SI}$ & Oil \\
Verkhniy Kazymskoye & & & & $\mathrm{SI}$ & Oil \\
Yelizarovskoye(Krasnoleninskoye) & 61.48 & 67.77 & 1963 & $\mathrm{SI}$ & Oil \\
Yemyegovskoye(Krasnoleninskoye) & 61.75 & 66.42 & 1971 & $\mathrm{DV}$ & Oil \\
Yendryskoye & 59.97 & 69.28 & 1992 & $\mathrm{SI}$ & Oil \\
Zaozernoye & 59.97 & 68.10 & 1987 & $\mathrm{SI}$ & Oil
\end{tabular}

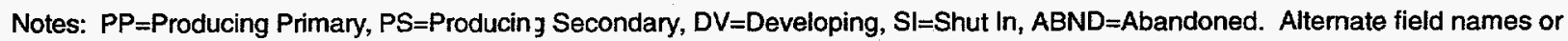
combined field names in parenthesis.

Source: Energy information Administration, Dffice of Oil and Gas. 
Table 12D. Calculated Crude Oil, Natural Gas, and Condensate Recovery by Field, Frolov Region, West Siberian Basin (Sorted Alphabetically by Field Name)

\begin{tabular}{|c|c|c|c|c|}
\hline Field Name & $\begin{array}{l}\text { Ultimate } \\
\text { Crude Oil } \\
\text { (million } \\
\text { barrels) } \\
\end{array}$ & $\begin{array}{l}\text { Associated- } \\
\text { Disolved Gas } \\
\text { (billion } \\
\text { cubic feet) }\end{array}$ & $\begin{array}{l}\text { Nonassociated } \\
\text { Gas } \\
\text { (billion } \\
\text { cubic feet) } \\
\end{array}$ & $\begin{array}{l}\text { Condensate } \\
\text { (million } \\
\text { barrels) }\end{array}$ \\
\hline Aprel'skoye & 51.92 & 14.07 & & \\
\hline Bol'shoye & 131.39 & 65.35 & & \\
\hline Dekabr'skoye & 4.17 & 1.70 & & \\
\hline Erginskoye & 94.61 & 14.76 & & \\
\hline Erginskoye Vostochnoye & 255.96 & 73.79 & & \\
\hline Frolovskoye Vostochnoye & 108.67 & 33.43 & & \\
\hline Galleyskoye & 3.77 & 1.27 & & \\
\hline Galyanovskoye & 439.81 & 183.40 & & \\
\hline Gorshkovskoye Zapadnoye & 70.03 & 21.64 & & \\
\hline Ingaskoye (Inginsk)(Krasnoleninskoye) & 18.22 & 6.72 & & \\
\hline It'yakhskoye & 9.11 & 3.36 & & \\
\hline Kamennoye(Krasnoleninskoye) & 58.88 & 14.80 & & \\
\hline Karempostskoye & 8.53 & 4.11 & & \\
\hline Kazymskoye Severnoye & & & 292.43 & 3.22 \\
\hline Khanty-Mansiyskoye (Tsentrainoye) & 171.59 & 39.06 & & \\
\hline Kislorskoye & 16.21 & 5.45 & & \\
\hline \multicolumn{5}{|l|}{ Krasnoleninskoye } \\
\hline Lebyazhyeskoye & & & 691.73 & 7.61 \\
\hline Lorbinskoye & 8.11 & 1.15 & & \\
\hline Lykhminskoye & 4.09 & 0.92 & & \\
\hline Malopriobskoye & 32.42 & 10.89 & & \\
\hline Nazymskoye & 80.11 & 26.92 & & \\
\hline Novoyendyrskoye & 160.70 & 59.30 & & \\
\hline Ol'khovskoye (Tyumen) & 427.54 & 50.02 & & \\
\hline Ontokhskoye & 344.37 & 135.68 & & \\
\hline Palyanovskoye & 280.53 & 42.63 & & \\
\hline Paytykhskoye & 86.52 & 29.07 & & \\
\hline Peschanoye & 13.19 & 3.50 & & \\
\hline Pottymskoye & 26.84 & 3.25 & & \\
\hline Priobskoye & $4,219.82$ & $1,202.65$ & & \\
\hline Priobskoye Severnoye & 6.81 & 2.29 & & \\
\hline Priobskoye Zapadnoye & 1.30 & 0.40 & & \\
\hline Prirakhtovskoye & 5.03 & 1.86 & & \\
\hline Rogozhnikovskoye & $1,388.21$ & 246.20 & & \\
\hline Rogozhnikovskoye Severnoye & 32.42 & 10.89 & & \\
\hline Rogozhnikovskoye Yuzhnoye & 14.42 & 4.84 & & \\
\hline Rogozhnikovskoye Zapadnoye & 32.42 & 10.89 & & \\
\hline Seliyarovskoye & 12.97 & 10.89 & & \\
\hline Seliyarovskoye Severnoye & 48.98 & 8.82 & & \\
\hline Sheburskoye Vostochnoye & 12.04 & 1.69 & & \\
\hline Sosnovomysskoye(Krasnoleninskoye) & 140.33 & 51.78 & & \\
\hline Sote-Yugan Severnoye & & & 10.52 & 0.12 \\
\hline Sote-Yugan Yuzhnoye & & & 91.37 & 1.01 \\
\hline \multicolumn{5}{|l|}{ Sote-Yuganskoye } \\
\hline Srednenazymskoye & 136.59 & 96.32 & & \\
\hline Sredniy Lykhmskoye & 72.10 & 24.22 & & \\
\hline \multicolumn{5}{|l|}{ Srednenazymskoye } \\
\hline Syn'yeganskoye & 54.46 & 21.27 & & \\
\hline Talinskoye & 299.39 & 110.47 & & \\
\hline Talinskoye Zapadnoye & 32.42 & 10.89 & & \\
\hline
\end{tabular}


Table 12D. Calculated Crude Oil, Natural Gas, and Condensate Recovery by Field, Frolov Region, West Siberian Basin (Sorted Alphabetically by Field Name) (Continued)

\begin{tabular}{lcccc}
\hline & $\begin{array}{c}\text { Uitimate } \\
\text { Crude Oil } \\
\text { (million } \\
\text { barrels) }\end{array}$ & $\begin{array}{c}\text { Associated- } \\
\text { Disolved Gas } \\
\text { (billion } \\
\text { cubic feet) }\end{array}$ & $\begin{array}{c}\text { Nonassociated } \\
\text { Gas } \\
\text { (billion } \\
\text { cubic feet) }\end{array}$ & $\begin{array}{c}\text { Condensate } \\
\text { (million } \\
\text { barrels) }\end{array}$ \\
\hline Taytymskoye & 23.99 & 8.85 & & \\
Tevrizskoye & & & 124.86 & 2.25 \\
Tevrizskoye Vostochnoye & 66.90 & 18.06 & 75.19 & 1.35 \\
Tortasinskoye & 37.32 & 18.73 & & \\
Tsentralnoye (Khanty-Mansiyskoye) & 59.82 & 22.07 & & \\
Tugrovskoye Severnoye & 78.70 & 26.44 & & \\
Tugrovskoye Vostochnoye & 32.42 & 10.89 & & \\
Tugrovskoye Zapadnoye & 12.06 & 3.68 & & \\
Tumannoye & 7.53 & 2.53 & & \\
Tunkorskoye & 57.59 & 29.84 & & \\
Verkhne-Lyaminskoye (Upper Lyarra) & 32.42 & 10.89 & & \\
Verkhniy Kazymskoye & 39.83 & 10.32 & & \\
Yelizarovskoye (Krasnoleninskoye) & 44.33 & 13.87 & & \\
Yemyegovskoye (Krasnoleninskoye) & 211.45 & 78.03 & & \\
Yendryskoye & 383.48 & 127.70 & & \\
Zaozernoye & & & & \\
& & & & \\
Total & $\mathbf{1 0 , 5 0 4 . 8 3}$ & $\mathbf{3 , 0 4 4 . 5 5}$ & $\mathbf{1 , 2 8 6 . 0 9}$ & \\
\end{tabular}

Notes: Alternate field names or combinations in parenthesis.

Source: Energy Information Administration, Office of Oil and Gas. 
Table 13D. Basic Field Information, Urals Region, West Siberian Basin (Sorted Alphabetically by Field Name)

\begin{tabular}{|c|c|c|c|c|c|}
\hline Field Name & $\begin{array}{l}\text { North } \\
\text { Latitude } \\
\text { (degrees) }\end{array}$ & $\begin{array}{l}\text { East } \\
\text { Latitude } \\
\text { (degrees) }\end{array}$ & $\begin{array}{c}\text { Discovery } \\
\text { Date }\end{array}$ & $\begin{array}{l}\text { Producing } \\
\text { Status }\end{array}$ & $\begin{array}{l}\text { Primary } \\
\text { Product }\end{array}$ \\
\hline Alyasovskoye Severnoye & 64.09 & 65.49 & 1956 & SI & Gas \\
\hline Alyasovskoye Yuzhnoye & 64.06 & 65.44 & 1956 & SI & Gas \\
\hline Berezovskoye (Tyumen) & 63.94 & 65.04 & 1953 & PP & Gas \\
\hline Chancharskoye Severnoye & 60.61 & 64.16 & & Si & Oil \\
\hline Chuelskoye & 63.86 & 65.93 & 1958 & $\mathrm{SI}$ & Gas \\
\hline Danilovskoye & 60.93 & 64.11 & 1966 & PS & Oil \\
\hline Danilovskoye Severnoye & 61.07 & 63.95 & 1983 & PS & Oil \\
\hline Danilovskoye Vostochnoye & 61.00 & 64.00 & 1983 & PP & Oil \\
\hline Danilovskoye Zapadnoye & 61.00 & 64.00 & 1966 & PP & Oil \\
\hline Deminskoye & 64.00 & 65.00 & 1955 & Si & Gas \\
\hline Filippovskoye & 60.91 & 64.83 & 1967 & PS & Oil \\
\hline Gornoye (Tyumen) & 62.40 & 63.50 & 1962 & DV & Gas \\
\hline Igrimskoye Severnoye & 63.13 & 64.44 & 1959 & ABND & Gas \\
\hline Igrimskoye Yuzhnoye & 63.09 & 64.34 & 1961 & PP & Gas \\
\hline Karabashskoye(Leninskoye) & 58.64 & 65.92 & 1964 & Si & Gas \\
\hline Kartop'ya & 61.10 & 65.31 & 1967 & SI & Oil \\
\hline Kartopya Zapadnoye & 60.13 & 65.28 & 1967 & SI & Oil \\
\hline Kartopya-Okhanskoye & 61.05 & 65.55 & 1967 & PS & Oil \\
\hline Kayumovskoye & 60.78 & 65.39 & 1971 & SI & Oil \\
\hline Khulturskoye & 60.48 & 64.10 & & si & Oil \\
\hline Lazarevskoye & 61.06 & 64.93 & 1984 & PS & Oil \\
\hline Lem'inskoye Vostochnoye & 61.00 & 63.83 & 1964 & SI & Oil \\
\hline Lem'inskoye Zapadnoye & 61.00 & 63.66 & 1965 & SI & Oil \\
\hline Leminskoye (Lemya) & 60.88 & 63.91 & 1964 & DV & Oil \\
\hline Leninskoye(Karabashskoye) & 58.67 & 66.33 & 1964 & PP & Gas \\
\hline Lopukhovskoye & 60.90 & 63.55 & & UKN & Oil \\
\hline Lovinskove & 61.30 & 65.19 & 1982 & PS & Oil \\
\hline Lovinskoye Zapadnoye & 61.25 & 65.00 & 1982 & SI & Oil \\
\hline Malo-Tolumskoye & 60.51 & 65.29 & 1978 & PP & Oil \\
\hline Malodanilovskoye & & & 1966 & SI & Oil \\
\hline Malopotanayskoye & 61.36 & 65.75 & 1989 & SI & Oil \\
\hline Mortym'yaskoye Severnoye & 60.40 & 64.80 & 1977 & PP & Oil \\
\hline Mortym'yaskoye Yuzhnoye & 60.40 & 64.80 & 1962 & PP & Oil \\
\hline Mortym'yaskoye Zapadnoye 1 & 60.40 & 64.80 & 1962 & PP & Oil \\
\hline Mortym'yaskoye Zapadnoye 2 & 60.40 & 64.80 & 1962 & PP & Oil \\
\hline Mortym'yaskoye Zapadnoye 3 & 60.40 & 64.80 & 1962 & PP & Oil \\
\hline Mulym'yaskoye & 60.24 & 64.42 & 1960 & PS & Oil \\
\hline Mulymyaskoye Srednyaya & 60.62 & 64.77 & 1963 & SI & Oil \\
\hline Mulymyaskoye Zapadnaya & 60.24 & 64.42 & 1960 & PP & Oil \\
\hline Nulin-Turskoye & 62.95 & 64.22 & 1961 & si & Gas \\
\hline Okhanskoye & 61.03 & 65.68 & 1967 & SI & Oil \\
\hline Ozernoye (Vostochnoye \& Zapadnoye) & 62.25 & 63.50 & 1963 & DV & Gas \\
\hline Paul-Turskoye & 63.09 & 64.16 & 1960 & SI & Gas \\
\hline Pokhromskoye & 64.08 & 65.83 & 1960 & PP & Gas \\
\hline Potanayskoye & 61.17 & 65.62 & 1965 & SI & Oil \\
\hline Potanayskoye Severnoye & 61.22 & 65.60 & 1965 & SI & Oil \\
\hline Potanayskoye Vostochnoye & 61.17 & 65.62 & 1990 & SI & Oil \\
\hline Potanayskoye Yuzhnoye (Potanaysk & 61.13 & 65.68 & 1966 & SI & Oil \\
\hline Punginskoye & 62.76 & 64.44 & 1961 & PP & Gas \\
\hline Semividovskoye Vostochnoye & 60.70 & 65.19 & 1967 & PS & Oil \\
\hline Shukhtungortskoye Vostochnny & 62.32 & 64.15 & 1963 & DV & Gas \\
\hline
\end{tabular}


Table 13D. Basic Field Information, Urals Region, West Siberian Basin (Sorted Alphabetically by Field Name) (Continued)

\begin{tabular}{|c|c|c|c|c|c|}
\hline Field Name & $\begin{array}{l}\text { North } \\
\text { Latitude } \\
\text { (degrees) }\end{array}$ & $\begin{array}{c}\text { East } \\
\text { Latitude } \\
\text { (degrees) }\end{array}$ & $\begin{array}{c}\text { Discovery } \\
\text { Date }\end{array}$ & $\begin{array}{c}\text { Producing } \\
\text { Status } \\
\end{array}$ & $\begin{array}{l}\text { Primary } \\
\text { Product }\end{array}$ \\
\hline Shukhtungortskoye Zapadnoye & 62.45 & 64.00 & 1962 & DV & Gas \\
\hline Shukhtungortskoye & 62.35 & 63.84 & 1962 & SI & Gas \\
\hline Shushminskoye & 61.22 & 64.14 & 1984 & PS & Oil \\
\hline Shushminskoye Severnoye & 61.25 & 64.32 & 1992 & SI & Oil \\
\hline Shushminskoye Yuzhnoye & 61.22 & 64.14 & & SI & Oil \\
\hline Slavinskoye & 60.75 & 64.50 & & SI & Oil \\
\hline Srednekondinskoye & 60.88 & 63.83 & 1982 & SI & Oil \\
\hline Sredneteterevskoye & 60.70 & 64.40 & 1970 & PP & Oil \\
\hline Surprinskoye Vostochnoye & 61.25 & 64.28 & 1986 & Si & Oil \\
\hline Symor'yakhskoye & 61.27 & 64.46 & 1988 & SI & Oil \\
\hline Syskonsyninskoye & 62.90 & 63.64 & 1961 & Si & Gas \\
\hline Syskonsynyaskoye Vostochnoye & 62.96 & 63.92 & 1961 & PP & Gas \\
\hline Syskonsynyaskoye Yuzhnoye & 62.88 & 63.70 & 1963 & DV & Gas \\
\hline Syskonsynyaskoye Zapadnoye & 62.93 & 63.69 & 1961 & DV & Gas \\
\hline Tal'nikovoye & 60.97 & 63.66 & 1989 & SI & Oil \\
\hline Teterevo-Mortyminskoye & 60.41 & 64.63 & 1961 & PS & Oil \\
\hline Teterevskoye Severnoye(Mortym) & 60.41 & 64.97 & 1968 & PP & Oil \\
\hline Teterevskoye Vostochnoye(Mortynin) & 60.41 & 64.97 & 1964 & PS & Oil \\
\hline Teterevskoye Yuzhnoye(Mortymin', & 60.33 & 64.83 & 1963 & PS & Oil \\
\hline Tolumskoye Vostochnoye & 60.56 & 65.29 & 1967 & PP & Oil \\
\hline Tolum-Semividovskoye & 60.75 & 65.33 & 1966 & PS & Oil \\
\hline Tolumskoye Servernoye & 60.75 & 65.33 & 1966 & PS & Oil \\
\hline Tolumskoye Yuzhnoye & 60.75 & 65.33 & 1966 & PS & Gas \\
\hline Trekhozernoye & 60.21 & 64.70 & 1960 & PS & Oil \\
\hline Trekhozernoye Severnoye & 60.21 & 64.70 & 1969 & PS & Oil \\
\hline Tugiyanskoye & 63.62 & 65.80 & 1960 & SI & Gas \\
\hline Ubinskove & 60.74 & 64.87 & 1964 & PP & Oil \\
\hline Ubinskoye Lesser & 60.82 & 64.83 & 1967 & PP & Oil \\
\hline Ubinskoye Servenoye & 60.82 & 64.83 & 1964 & PP & Oil \\
\hline Ubinskoye Yuzhnoye & 60.82 & 64.83 & 1965 & PP & Oil \\
\hline Ubinskoye Zapadnoye & 60.82 & 64.83 & 1966 & PP & Oil \\
\hline Uzbekskoye & 60.27 & 64.22 & 1988 & PP & Oil \\
\hline Uzbekskoye Severnoye & 60.27 & 64.22 & 1989 & PP & Oil \\
\hline Uzbekskoye-Sredne-Chanchar & 60.53 & 64.22 & 1988 & PS & Oil \\
\hline Uzbelskoye Yuzhnoye & 60.27 & 64.22 & 1988 & SI & Oil \\
\hline Verkhnelem'inskoye & 61.09 & 64.13 & 1966 & PS & Oil \\
\hline Verkhnesuprinskoye & 61.25 & 64.30 & 1986 & SI & Oil \\
\hline Verkhnyaya Kondaskoye & 61.40 & 63.88 & 1963 & SI & Gas \\
\hline Yakhlaskove & 61.40 & 65.43 & 1971 & PS & Oil \\
\hline
\end{tabular}

Notes: PP=Producing Primary, PS=Producing Secondary, DV=Developing, $S I=S h u t ~ I n, A B N D=A b a n d o n e d, U K N=U n k n o w n$. Alternate field names or combined field names in partenthesis.

Source: Energy information Administratior, Office of Oil and Gas. 
Table 14D. Calculated Crude Oil, Natural Gas, and Condensate Recovery by Field, Urals Region, West Siberian Basin (Sorted Alphabetically by Field Name)

\begin{tabular}{|c|c|c|c|c|}
\hline Field Name & $\begin{array}{l}\text { Ultimate } \\
\text { Crude Oil } \\
\text { (million } \\
\text { barrels) }\end{array}$ & $\begin{array}{l}\text { Associated- } \\
\text { Disolved Gas } \\
\text { (billion } \\
\text { cubic feet) }\end{array}$ & $\begin{array}{l}\text { Nonassociated } \\
\text { Gas } \\
\text { (billion } \\
\text { cubic feet) } \\
\end{array}$ & $\begin{array}{c}\text { Condensate } \\
\text { (million } \\
\text { barrels) }\end{array}$ \\
\hline Alyasovskoye Severnoye & & & 36.18 & 0.44 \\
\hline Alyasovskoye Yuzhnoye & & & 48.52 & 0.55 \\
\hline Berezovskoye (Tyumen) & & & 336.47 & 3.70 \\
\hline Chancharskoye Severnoye & 12.51 & 4.35 & & \\
\hline Chuelskoye & & & 174.13 & 1.92 \\
\hline Danilovskoye & 89.21 & 28.73 & & \\
\hline Danilovskoye Severnoye & 12.51 & 4.35 & & \\
\hline Danilovskoye Vostochnoye & 12.51 & 4.35 & & \\
\hline Danilovskoye Zapadnoye & 12.51 & 4.35 & & \\
\hline Deminskoye & & & 149.82 & 1.78 \\
\hline Filippovskoye & 10.58 & 3.33 & & \\
\hline Gornoye (Tyumen) & & & 89.36 & 0.98 \\
\hline Igrimskoye Severnoye & & & 123.20 & 1.36 \\
\hline Igrimskoye Yuzhnoye & & & 95.25 & 1.05 \\
\hline Karabashskoye(Leninskoye) & & & 20.42 & 0.22 \\
\hline Kartop'ya & 40.43 & 27.98 & & \\
\hline Kartopya Zapadnoye & 0.40 & 0.09 & & \\
\hline Kartopya-Okhanskoye & 8.49 & 1.80 & & \\
\hline Kayumovskoye & 14.11 & 6.65 & & \\
\hline Khulturskoye & 72.22 & 25.09 & & \\
\hline Lazarevskoye & 12.51 & 4.35 & & \\
\hline Lem'inskoye Vostochnoye & 11.74 & 4.08 & & \\
\hline Lem'inskoye Zapadnoye & 11.74 & 4.08 & & \\
\hline Leminskoye (Lemya) & 5.05 & 1.86 & & \\
\hline Leninskoye(Karabashskoye) & & & 52.32 & 0.58 \\
\hline Lopukhovskoye & 12.51 & 4.35 & & \\
\hline Lovinskoye & 55.97 & 25.74 & & \\
\hline Lovinskoye Zapadnoye & 158.51 & 58.49 & & \\
\hline Malo-Tolumskoye & 1.81 & 0.63 & & \\
\hline Malodanilovskoye & 12.51 & 4.35 & & \\
\hline Malopotanayskoye & 1.81 & 0.63 & & \\
\hline Mortym'yaskoye Severnoye & 92.65 & 30.22 & & \\
\hline Mortym'yaskoye Yuzhnoye & 22.41 & 9.40 & & \\
\hline Mortym'yaskoye Zapadnoye 1 & 12.51 & 4.35 & & \\
\hline Mortym'yaskoye Zapadnoye 2 & 12.51 & 4.35 & & \\
\hline Mortym'yaskoye Zapadnoye 3 & 18.38 & 4.28 & & \\
\hline Mulym'yaskoye & 18.79 & 5.92 & & \\
\hline Mulymyaskoye Srednyaya & 16.91 & 6.24 & & \\
\hline Mulymyaskoye Zapadnaya & 1.35 & 0.47 & & \\
\hline Nulin-Turskoye & & & 10.66 & 0.12 \\
\hline Okhanskoye & 12.51 & 4.35 & & \\
\hline Ozernoye (Vostochnoye \& Zapadnoye) & & & 8.07 & 0.09 \\
\hline Paul-Tur & & & 8.98 & 0.10 \\
\hline Pokhromskoye & & & 889.34 & 9.78 \\
\hline Potanayskoye & 95.50 & 90.25 & & \\
\hline Potanayskoye Severnoye & 3.32 & 1.41 & & \\
\hline Potanayskoye Vostochnoye & 1.81 & 0.63 & & \\
\hline Potanayskoye Yuzhnoye (Potanayskoye) & 15.87 & 6.69 & & \\
\hline $\begin{array}{l}\text { Punginskoye } \\
\text { Semividovskoye Vostochnoye }\end{array}$ & & & 544.84 & 5.99 \\
\hline
\end{tabular}


Table 14D. Calculated Crude Oil, Natural Gas, and Condensate Recovery by Field, Urals Region, West Siberiar! Basin (Sorted Alphabetically by Field Name). (Continued)

\begin{tabular}{|c|c|c|c|c|}
\hline Field Name & $\begin{array}{l}\text { Ultimate } \\
\text { Crude Oil } \\
\text { (million } \\
\text { barrels) } \\
\end{array}$ & $\begin{array}{l}\text { Associated- } \\
\text { Disolved Gas } \\
\text { (billion } \\
\text { cubic feet) }\end{array}$ & $\begin{array}{l}\text { Nonassociated } \\
\text { Gas } \\
\text { (billion } \\
\text { cubic feet) } \\
\end{array}$ & $\begin{array}{l}\text { Condensate } \\
\text { (million } \\
\text { barrels) }\end{array}$ \\
\hline Shukhtungortskoye Vostochnny & & & 149.86 & 1.65 \\
\hline Shukhtungortskoye Zapadnoye & & & 92.74 & 1.02 \\
\hline Shukhtungortskoye & & & 135.96 & 1.50 \\
\hline Shushminskoye & 65.94 & 23.96 & & \\
\hline Shushminskoye Severnoye & 6.49 & 2.40 & & \\
\hline Shushminskoye Yuzhnoye & 12.51 & 4.36 & & \\
\hline Slavinskoye & 12.51 & 4.38 & & \\
\hline Srednekondinskoye & 2.00 & 1.00 & & \\
\hline Sredneteterevskoye & 12.51 & 4.36 & & \\
\hline Surprinskoye Vostochnoye & 2.00 & 1.00 & & \\
\hline Symor'yakhskoye & 12.51 & 4.36 & & \\
\hline Syskonsyninskoye & & & $1,513.39$ & 16.65 \\
\hline Syskonsynyaskoye Vostochnaya & & & 242.79 & 2.67 \\
\hline Syskonsynyaskoye Yuzhnaya & & & 91.41 & 1.01 \\
\hline Syskonsynyaskoye Zapadnaya & & & 188.38 & 2.07 \\
\hline Tal'nikovoye & 56.83 & 20.97 & & \\
\hline Teterevo-Mortyminskoye & 341.37 & 120.71 & 888.28 & 9.77 \\
\hline Teterevskoye Severnoye(Mortym) & 62.80 & 22.21 & & \\
\hline Teterevskoye Vostochnoye(Mortymi ר) & 12.69 & 1.76 & & \\
\hline Teterevskoye Yuzhnoye(Mortymin) & 146.62 & 54.39 & 80.70 & 0.89 \\
\hline Tolumskoye Vostochnoye & 29.69 & 10.95 & & \\
\hline Tolum-Semividovskoye & & & & \\
\hline Tolumskoye Servernoye & 40.97 & 7.73 & & \\
\hline Tolumskoye Yuzhnoye & 25.42 & 5.00 & & \\
\hline Trekhozernoye & 161.19 & 45.83 & & \\
\hline Trekhozernoye Severnoye & 23.10 & 11.97 & & \\
\hline Tugiyanskoye & & & 2.13 & 0.02 \\
\hline Ubinskoye & 6.40 & 2.36 & & \\
\hline Ubinskoye Lesser & 5.57 & 1.08 & & \\
\hline Ubinskoye Servenoye & 7.60 & 1.47 & & \\
\hline Ubinskoye Yuzhnoye & 3.83 & 0.55 & & \\
\hline Ubinskoye Zapadnoye & 5.20 & 1.00 & & \\
\hline Uzbekskoye & 191.95 & 70.83 & & \\
\hline Uzbekskoye Severnoye & 12.51 & 4.36 & & \\
\hline Uzbekskoye-Sredne-Chanchar & 17.01 & 5.93 & & \\
\hline Uzbelskoye Yuzhnoye & 12.51 & 4.36 & & \\
\hline Verkhnelem'inskoye & 36.83 & 13.59 & & \\
\hline Verkhnesuprinskove & 2.00 & 1.00 & & \\
\hline Verkhnyaya Kondaskoye & & & 146.14 & 1.61 \\
\hline Yakhlaskoye & 509.74 & 238.08 & & \\
\hline TOTAL & $2,732.53$ & $1,080.13$ & $6,119.33$ & 67.50 \\
\hline
\end{tabular}

Notes: Alternate field names or combinaticns in parenthesis.

Source: Energy Information Administration, Office of Oil and Gas. 
Table 15D. Basic Field Information, Kaymysov Region, West Siberian Basin (Sorted Alphabetically by Field Name)

\begin{tabular}{|c|c|c|c|c|c|}
\hline Field Name & $\begin{array}{c}\text { North } \\
\text { Latitude } \\
\text { (degrees) }\end{array}$ & $\begin{array}{l}\text { East } \\
\text { Latitude } \\
\text { (degrees) }\end{array}$ & $\begin{array}{c}\text { Discovery } \\
\text { Date }\end{array}$ & $\begin{array}{c}\text { Producing } \\
\text { Status } \\
\end{array}$ & $\begin{array}{l}\text { Primary } \\
\text { Product }\end{array}$ \\
\hline Archinskoye & 57.49 & 78.50 & 1985 & SI & Oil \\
\hline Ay-Yaunskoye & 59.31 & 72.76 & 1968 & SI & Oil \\
\hline Aykuruskoye & 59.80 & 73.72 & 1988 & SI & Oil \\
\hline Chvorovoye (Vasyuganskiy) & 58.58 & 76.95 & 1980 & SI & Oil \\
\hline Demyanskoye Severnoye & 59.53 & 70.81 & 1988 & SI & Oil \\
\hline Duklinskoye & 59.33 & 75.80 & 1990 & PP & Oil \\
\hline Fedyushkinskoye & 57.77 & 76.31 & 1985 & PP & Oil \\
\hline Fedyushkinskoye Severnoye & 57.88 & 76.35 & 1987 & SI & Oil \\
\hline Gerasimovskoye & 57.65 & 78.92 & 1983 & PP & Oil \\
\hline Glukhovskoye & 58.03 & 76.78 & 1983 & SI & Oil \\
\hline Gustorechenskoye & 58.07 & 73.55 & 1992 & Sl & Oil \\
\hline Igol'sko-Talovoye & 57.64 & 76.24 & 1977 & PS & Oil \\
\hline Kalchinskoye & 59.20 & 69.99 & 1990 & PP & Oil \\
\hline Kalchinskoye Severnoye & 59.30 & 70.00 & 1991 & SI & Oil \\
\hline Kalinovoye & 57.42 & 79.10 & 1973 & SI & Gas \\
\hline Kalinovoye Severnoye & 57.51 & 79.01 & 1980 & SI & Oil \\
\hline Kalinovoye Vostochnoye & 57.44 & 79.21 & 1973 & SI & Oil \\
\hline Karasevskoye (Tomsk) & 58.43 & 76.04 & 1985 & SI & Oil \\
\hline Karasevskoye Severnoye & 58.48 & 76.06 & 1988 & SI & Oil \\
\hline Karasevskoye Zapadnoye & & & & SI & Oil \\
\hline Karayskoye & 57.70 & 75.96 & 1980 & DV & Oil \\
\hline Karayskoye Zapadnoye & 57.75 & 75.62 & 1983 & SI & Oil \\
\hline Katyl'ginskoye & 59.14 & 76.29 & 1965 & PS & Oil \\
\hline Katyl'ginskoye Zapadnoye & 59.07 & 76.07 & 1972 & PS & Oil \\
\hline Kazanskoye & 57.21 & 79.34 & 1967 & SI & Gas \\
\hline Krapivinskoye & 58.03 & 75.68 & 1969 & SI & Oil \\
\hline Krapivinskoye Severnoye & 58.07 & 75.74 & 1986 & SI & Oil \\
\hline Krapivinskoye Vostochnoye & 58.09 & 75.73 & 1986 & SI & Oil \\
\hline Larlominskoye Yuzhnoye & 58.98 & 75.30 & & SI & Oil \\
\hline Larlomkinskoye & 59.08 & 75.31 & 1971 & SI & Oil \\
\hline Lontyn'yakhskoye & 58.88 & 76.00 & 1964 & PP & Oil \\
\hline Lower Tabaganskoye & 57.30 & 79.00 & 1985 & SI & Oil \\
\hline Maloichskoye & 56.82 & 78.48 & 1974 & PP & Oil \\
\hline Maloveselovskoye & 56.42 & 77.98 & 1964 & SI & Oil \\
\hline Mezhovskoye & 56.54 & 77.86 & 1964 & SI & Oil \\
\hline Mezhovskoye Vostochnoye & 56.59 & 78.12 & 1966 & SI & Oil \\
\hline Moiseyevskoye & 58.19 & 76.06 & 1970 & SI & Oil \\
\hline Moiseyevskoye Zapadnoye & 58.20 & 75.83 & 1992 & SI & Oil \\
\hline Multanovskoye & 60.08 & 73.55 & 1971 & DV & Oil \\
\hline Nalim'yeskoye & 57.84 & 76.74 & 1987 & SI & Oil \\
\hline Nizhne Tabaganskoye & 58.25 & 79.17 & 1973 & SI & Oll \\
\hline Nizhniy Keumskoye & 59.59 & 71.36 & & SI & Oil \\
\hline Novyy-Tutymskoye & 58.80 & 74.20 & 1988 & SI & Oil \\
\hline Olen'yeskoye & 59.36 & 76.34 & 1967 & PS & Oil \\
\hline Olen'yeskoye Severnoye & 59.40 & 76.40 & 1989 & PP & Oil \\
\hline Ozernoye (Tomsk) & 59.20 & 76.47 & 1970 & PS & Oil \\
\hline Pavlovskoye (Tomsk) & 58.50 & 75.78 & 1989 & SI & Oil \\
\hline Pervomayskoye (Tomsk) & 59.05 & 75.96 & 1969 & PS & Oil \\
\hline Polun'yakhskoye & 59.54 & 73.03 & 1990 & SI & Oil \\
\hline Pon'zhevoye & 57.92 & 76.52 & 1983 & SI & Oil \\
\hline Poselkovoye & 58.56 & 76.47 & 1982 & SI & Oil \\
\hline
\end{tabular}


Table 15D. Basic Field Information, Kaymysov Region, West Siberian Basin (Sorted Alphabetically by Field Name) (Continued)

\begin{tabular}{lccccc}
\hline Field Name & $\begin{array}{c}\text { North } \\
\text { Latitude } \\
\text { (degrees) }\end{array}$ & $\begin{array}{c}\text { East } \\
\text { Latitude } \\
\text { (degrees) }\end{array}$ & $\begin{array}{c}\text { Discovery } \\
\text { Date }\end{array}$ & $\begin{array}{c}\text { Producing } \\
\text { Status }\end{array}$ & $\begin{array}{c}\text { Primary } \\
\text { Product }\end{array}$ \\
\hline Rakitinskoye & 56.96 & 78.96 & 1971 & SI & Oil \\
Shirotnoye & 56.68 & 80.78 & 1988 & SI & Oil \\
Smolyanoye & 57.35 & 78.41 & 1987 & SI & Oil \\
Solonovskoye & 57.21 & 78.99 & 1986 & SI & Oil \\
Stolbovoye & 59.27 & 76.57 & 1986 & DV & Oil \\
Tabagan Yuzhnoye & 57.29 & 78.96 & 1983 & SI & Oil \\
Tagayskoye & 57.97 & 76.02 & 1987 & SI & Oil \\
Tambayeyskoye Yuzhnoye & 57.69 & 78.58 & 1986 & SI & Oil \\
Tarskoye Vostochnoye & 56.86 & 78.86 & 1986 & SI & Oil \\
Tay-Das (Dasskoye) & 56.73 & 79.13 & 1971 & SI & Oil \\
Tay-Das Vostochnoye & 56.68 & 79.22 & & SI & Oil \\
Taylakovskoye & 59.14 & 74.11 & 1964 & SI & Oil \\
Travyanoye & 59.08 & 74.05 & & SI & Oil \\
Tukanskoye & 59.82 & 72.39 & 1963 & SI & Oil \\
Urmanskoye & 57.62 & 78.45 & 1974 & SI & Oil \\
Urnenskoye & 58.66 & 73.38 & 1970 & SI & Oil \\
Usanovkoye & 58.56 & 73.68 & 1971 & SI & Oil \\
Verkhnetarskoye & 56.74 & 78.75 & 1971 & PP & Oil \\
Veselovskoye & 56.52 & 78.15 & 1965 & SI & Gas \\
Vesennee & 59.08 & 76.00 & 1973 & SI & Oil \\
Vesenneye Zapadnoye & & & & SI & Oil \\
Vostochnoye(Novosibirsk) & 56.70 & 79.29 & 1986 & SI & Oil \\
Yagyl'yakhskoye & 57.74 & 75.20 & 1982 & SI & Oil \\
Yelleyskoye(Yelley) & 57.60 & 77.68 & 1983 & SI & Oil \\
Yutymskoye Severnoye & 59.00 & 74.16 & 1989 & SI & Oil \\
& & & & &
\end{tabular}

Notes: PP=Producing Primary, PS=Producinc Secondary, DV=Developing, SI=Shut In, ABND=Abandoned. Alternate field names or combined field names in parenthesis.

Source: Energy information Administration, Cffice of Oil and Gas. 
Table 16D. Calculated Crude Oil, Natural Gas, and Condensate Recovery by Field, Kaymysov Region, West Siberian Basin (Sorted Alphabetically by Field Name)

\begin{tabular}{lcccc}
\hline & Ultimate & Associated- & Nonassociated & Condensate \\
Crude Oil & Disolved Gas & Gas & Condension \\
(million & (billion & (billion & (million \\
barrels) & cubic feet) & cubic feet) & barrels) \\
\hline
\end{tabular}

Archinskoye

Ay-Yaunskoye

Aykuruskoye

Chvorovoye (Vasyuganskiy)

Demyanskoye Severnoye

Duklinskoye

Fedyushkinskoye

Fedyushkinskoye Severnoye

Gerasimovskoye

Glukhovskoye

Gustorechenskoye

Igol'sko-Talovoye

Kalchinskoye

Kalchinskoye Severnoye

Kalinovoye Severnoye

Kalinovoye Vostochnoye

Kalinovoye

Karasevskoye Severnoye

Karasevskoye (Tomsk)

Karasevskoye Zapadnoye

Karayskoye Zapadnoye

Karayskoye

Katyl'ginskoye Zapadnoye

Katyl'ginskoye

Kazanskoye

Krapivinskoye Vostochnoye

Krapivinskoye Severnoye

Krapivinskoye

Larlominskoye Yuzhnoye

Larlomkinskoye

Lontyn'yakhskoye

Lower Tabaganskoye

Maloichskoye

Maloveselovskoye

Mezhovskoye Vostochnoye

Mezhovskoye

Moiseyevskoye Zapadnoye

Moiseyevskoye

Multanovskoye

Nalim'yeskoye

Nizhne Tabaganskoye

Nizhniy Keumskoye

Novyy-Tutymskoye

Olen'yeskoye Severnoye

Olen'yeskoye

Ozernoye (Tomsk)

Pavlovskoye (Tomsk)

Pervomayskoye (Tomsk)

Polun'yakhskoye

Pon'zhevoye
59.72

524.22

144.08

3.81

20.66

27.37

113.32

2.71

49.67

4.09

25.27

143.75

33.07

11.12

30.39

0.22

191.60

10.47

30.89

11.12

17.97

25.11

21.37

150.91

34.22

17.31

150.28

11.12

5.12

16.14

20.85

36.10

1.94

50.57

119.27

9.53

29.25

41.91

17.26

111.58

11.12

11.12

27.24

$1,089.17$

15.77

18.16

108.85

11.12

4.37
22.04

89.12

54.46

1.44

3.39

10.35

13.37

0.35

18.50

1.55

9.55

31.77

5.52

9.82

12.40

0.10

$2,912.44$

3.96

11.68

9.82

6.79

6.23

4.86

35.13

5.99

3.25

50.50

9.82

1.33

3.44

129.04

12.18

0.35

20.74

36.85

3.60

6.58

15.84

6.53

42.14

9.82

9.82

11.47

351.80

8.12

16.03

28.19

9.82

0.59
790.74

106.29

3.11

533.59

28.71

455.90

17.49

$1,702.66$

26.35

55.73

1.63 
Table 16D. Calculated Crude Oil, Natural Gas, and Condensate Recovery by Field, Kaymysov Region, West Siberian Basin (Sorted Alphabetically by Field Name) (Continued)

\begin{tabular}{|c|c|c|c|c|}
\hline Field Name & $\begin{array}{l}\text { Ultimate } \\
\text { Crude Oil } \\
\text { (million } \\
\text { barrels) } \\
\end{array}$ & $\begin{array}{l}\text { Associated- } \\
\text { Disolved Gas } \\
\text { (billion } \\
\text { cubic feet) }\end{array}$ & $\begin{array}{l}\text { Nonassociated } \\
\text { Gas } \\
\text { (billion } \\
\text { cubic feet) } \\
\end{array}$ & $\begin{array}{l}\text { Condensate } \\
\text { (million } \\
\text { barrels) }\end{array}$ \\
\hline Poselkovoye & 6.14 & 1.38 & & \\
\hline Rakitinskoye & 148.49 & 28.21 & & \\
\hline Shirotnoye & 47.32 & 17.89 & & \\
\hline Smolyanoye & 6.43 & 2.43 & & \\
\hline Solonovskoye & 10.60 & 4.45 & & \\
\hline Stolbovoye & 82.71 & 23.16 & & \\
\hline Tabaganskove Yuzhnove & 4.71 & 2.22 & & \\
\hline Tagayskoye & 152.48 & 25.62 & & \\
\hline Tambayeyskoye Yuzhnoye & 2.76 & 1.02 & & \\
\hline Tarskoye Vostochnoye & 1.60 & 0.71 & & \\
\hline Tay-Das Vostochnoye & 11.12 & 9.82 & & \\
\hline Tay-Das (Dasskoye) & 3.94 & 1.49 & & \\
\hline Taylakovskoye & 15.23 & 5.76 & & \\
\hline Travyanoye & 49.65 & 9.82 & & \\
\hline Tukanskoye & 226.04 & 85.44 & & \\
\hline Urmanskoye & 225.63 & 85.29 & & \\
\hline Urnenskoye & 16.32 & 10.41 & & \\
\hline Usanovskoye & 63.40 & 23.97 & & \\
\hline Verkhnetarskoye & 49.06 & 29.59 & & \\
\hline Veselovskoye & & & 18.03 & 0.29 \\
\hline Vesennee & 9.63 & 2.77 & & \\
\hline Vesenneye Zapadnoye & 11.12 & 9.82 & & \\
\hline Vostochnoye(Novosibirsk) & 31.90 & 28.17 & & \\
\hline Yagyl'yakhskoye & 11.12 & 9.82 & & \\
\hline Yelleyskoye(Yelley) & 0.56 & 0.21 & & \\
\hline Yutymskoye Severnoye & 2.00 & 1.00 & & \\
\hline TOTAL & $4,812.24$ & $4,488.92$ & $3,662.94$ & 77.59 \\
\hline
\end{tabular}

Notes: Alternate field names or combinations in parenthesis.

Source: Energy Information Administratio 1, Office of Oil and Gas. 
Table 17D. Basic Field Information, Vasyugan Region, West Siberian Basin (Sorted Alphabetically by Field Name)

\begin{tabular}{|c|c|c|c|c|c|}
\hline Field Name & $\begin{array}{c}\text { North } \\
\text { Latitude } \\
\text { (degrees) }\end{array}$ & $\begin{array}{c}\text { East } \\
\text { Latitude } \\
\text { (degrees) }\end{array}$ & $\begin{array}{c}\text { Discovery } \\
\text { Date }\end{array}$ & $\begin{array}{c}\text { Producing } \\
\text { Status } \\
\end{array}$ & $\begin{array}{l}\text { Primary } \\
\text { Product }\end{array}$ \\
\hline Ariolskoye & 61.34 & 78.52 & 1992 & SI & Oil \\
\hline Chebachyeskoye & 60.62 & 78.83 & 1966 & DV & Oil \\
\hline Cheremshanskoye Yuzhnoye & 58.90 & 76.85 & 1970 & SI & Oil \\
\hline Chkalovskoye & 59.69 & 78.74 & 1977 & PS & Oil \\
\hline Enitorskoye & 61.52 & 78.93 & 1982 & SI & Oil \\
\hline Enitorskoye Yuzhnoye & 61.40 & 78.97 & 1988 & SI & Oil \\
\hline Festivalnoye (Tomsk)(Aykagol'skoye) & 58.28 & 77.28 & 1971 & SI & Oil \\
\hline Festivalnoye Yuzhno & 58.20 & 77.28 & 1969 & SI & Oil \\
\hline Gorstovoye & 60.54 & 78.36 & 1987 & SI & Oil \\
\hline Grushevoye & 59.38 & 77.13 & 1987 & SI & Oil \\
\hline Ininskoye & 61.05 & 78.83 & 1990 & SI & Oil \\
\hline Khokhryakovskoye & 61.53 & 79.39 & 1972 & PS & Oil \\
\hline Khokhryakovskoye Severnoye & 62.04 & 79.52 & 1976 & PS & Oil \\
\hline Klyuchevskoye (Tomsk) & 58.84 & 77.53 & 1968 & PP & Oil \\
\hline Kolikyeganskoye & 61.34 & 79.16 & 1971 & DV & Oil \\
\hline Kolikyeganskoye Vostochnoye & & & 1987 & SI & Oil \\
\hline Kolotuchnoye & 58.68 & 77.50 & 1986 & SI & Oil \\
\hline Kondakovskoye (Tomsk) & 60.37 & 78.74 & 1982 & SI & Oil \\
\hline Kondinskoye Vostochnoye & & & 1991 & Sl & Oil \\
\hline Koshilsko-Vakhskoye & 61.07 & 79.22 & 1987 & PS & Oil \\
\hline Krasnoyarskoye Zapadnoye & 59.08 & 77.83 & 1965 & SI & Oil \\
\hline Kulyeganskoye(Tomsk) & 60.01 & 77.76 & 1988 & SI & Oil \\
\hline Lomovoye & 59.28 & 77.04 & 1970 & PP & Oil \\
\hline Luginetskoye & 58.25 & 78.87 & 1967 & PP & Gas \\
\hline Luginetskoye Zapadnoye & 58.20 & 78.88 & 1990 & SI & Oil \\
\hline Malo Kolikyeganskoye & & & 1987 & SI & Oil \\
\hline Mirnoye & 57.67 & 79.50 & 1982 & SI & Gas \\
\hline Mykhlorskoye & 61.31 & 77.53 & 1985 & SI & Oil \\
\hline Myldzhinskoye & 58.74 & 78.44 & 1964 & DV & Gas \\
\hline Myldzhinskoye Yuzhnoye & 58.51 & 78.15 & 1967 & SI & Oil \\
\hline Nazinskoye Yuzhnoye & 60.07 & 78.73 & 1961 & SI & Oil \\
\hline Nikol'skove (Tomsk) & 59.97 & 79.05 & 1971 & SI & Oil \\
\hline Nikol'skoye (Tyumen) & 61.45 & 77.58 & 1985 & PS & Oil \\
\hline Nizhne-Tobolyanskoye & 58.42 & 78.83 & 1975 & SI & Oil \\
\hline Okhteurskoye Vostochnoye & & & 1994 & SI & Oil \\
\hline Okhteurskoye Yuzhnny & 60.76 & 78.50 & 1990 & $\mathrm{SI}$ & Oil \\
\hline Ostaninskoye & 57.70 & 79.37 & 1970 & DV & Gas \\
\hline Ostaninskoye Severnoye & 57.91 & 79.29 & 1977 & SI & Oil \\
\hline Ostaninskoye Zapadnoye & 57.73 & 79.04 & 1972 & PS & Oil \\
\hline Permyakovskoye & 61.34 & 79.55 & 1972 & PS & Oil \\
\hline Pindzhinskoye & 57.64 & 79.68 & 1985 & SI & Oil \\
\hline Pionerskoye & 58.97 & 77.27 & & $\mathrm{SI}$ & Oil \\
\hline Poludennoye (Tomsk) & 60.08 & 78.25 & 1967 & PS & Oil \\
\hline Poludennoye Severnoye & & & 1992 & SI & Oil \\
\hline Protochnoye & 60.65 & 78.33 & 1978 & SI & Oil \\
\hline Protochnoye Severnoye & 60.63 & 78.20 & 1979 & SI & Oil \\
\hline Protochnoye Yuzhnoye & 60.52 & 78.17 & 1978 & SI & Oil \\
\hline Puglalymskoye & 58.89 & 77.73 & 1971 & SI & Oil \\
\hline Rechnoye & 58.39 & 77.92 & 1981 & SI & Gas \\
\hline Rybalnoye & 58.18 & 79.83 & 1988 & SI & Oil \\
\hline Selimkhanovskoye & 57.87 & 80.18 & 1981 & SI & Oil \\
\hline
\end{tabular}


Table 17D. Basic Field Information, Vasyugan Region, West Siberian Basin (Sorted Alphabetically by Field Name) (Continued)

\begin{tabular}{lccccc}
\hline Field Name & $\begin{array}{c}\text { North } \\
\text { Latitude } \\
\text { (degrees) }\end{array}$ & $\begin{array}{c}\text { East } \\
\text { Latitude } \\
\text { (degrees) }\end{array}$ & $\begin{array}{c}\text { Discovery } \\
\text { Date }\end{array}$ & $\begin{array}{c}\text { Producing } \\
\text { Status }\end{array}$ & $\begin{array}{c}\text { Primary } \\
\text { Product }\end{array}$ \\
\hline Severnoye & 60.76 & 78.50 & 1965 & PS & Oil \\
Shinginskoye & 58.31 & 78.49 & 1971 & SI & Oil \\
Siktorskoye Severnoye & 62.03 & 79.62 & 1976 & SI & Oil \\
Sredne-Vasyuganskoye & 59.13 & 77.83 & 1965 & PP & Oil \\
Srednenyurol'skoye & 58.92 & 77.87 & 1965 & SI & Oil \\
Stavropolskoye & & & 1990 & SI & Oil \\
Tul'yeganskoye & 61.35 & 77.90 & 1983 & SI & Oil \\
Tungolskoye & 60.33 & 80.49 & 1973 & SI & Oil \\
Vakh River & 60.98 & 78.96 & 1965 & DV & Oil \\
Vakhskoye Severnoye & 60.85 & 78.98 & & SI & Oil \\
Vakhskoye Yuzhnoye & 60.28 & 79.88 & 1968 & SI & Oil \\
Vartovskoye & 59.37 & 78.38 & 1964 & PI & Oil \\
Vasyugan Severnoye & 58.48 & 78.04 & 1967 & SI & Gas \\
Verkhne-Salatskoye & 57.50 & 80.28 & 1971 & SI & Gas \\
Verkhnekambarskoye & 61.75 & 79.13 & 1982 & SI & Oil \\
Vonterskoye & & & & &
\end{tabular}

Notes: PP=Producing Primary, PS=Producinu Secondary, DV=Developing, SI=Shut In, ABND=Abandoned. Alternate field names or combined field names in parenthesis.

Source: Energy information Administration, (Office of Oil and Gas. 
Table 18D. Calculated Crude Oil, Natural Gas, and Condensate Recovery by Field, Vasyugan Region, West Siberian Basin (Sorted Alphabetically by Field Name)

\begin{tabular}{|c|c|c|c|c|}
\hline Field Name & $\begin{array}{l}\text { Ultimate } \\
\text { Crude Oil } \\
\text { (million } \\
\text { barrels) } \\
\end{array}$ & $\begin{array}{l}\text { Associated- } \\
\text { Disolved Gas } \\
\text { (billion } \\
\text { cubic feet) }\end{array}$ & $\begin{array}{l}\text { Nonassociated } \\
\text { Gas } \\
\text { (billion } \\
\text { cubic feet) } \\
\end{array}$ & $\begin{array}{c}\text { Condensate } \\
\text { (million } \\
\text { barrels) }\end{array}$ \\
\hline Ariolskoye & 38.56 & 14.65 & & \\
\hline Chebachyeskoye & 297.55 & 109.80 & & \\
\hline Cheremshanskoye Yuzhnoye & 20.24 & 3.95 & & \\
\hline Chkalovskoye & 23.57 & 15.24 & 221.77 & 4.44 \\
\hline Enitorskoye & 39.05 & 14.76 & & \\
\hline Enitorskoye Yuzhnoye & 11.17 & 6.87 & & \\
\hline Festivalnoye Yuzhnoye & 7.36 & 2.78 & & \\
\hline Festivalnoye (Tomsk)(Aykagol'skoye) & 236.55 & 52.08 & & \\
\hline Gorstovoye & 7.67 & 2.39 & & \\
\hline Grushevoye & 28.49 & 7.49 & & \\
\hline Ininskoye & 5.14 & 1.94 & & \\
\hline Khokhryakovskoye Severnoye & 187.28 & 189.23 & & \\
\hline Khokhryakovskoye & 353.42 & 146.32 & & \\
\hline Klyuchevskoye (Tomsk) & 28.82 & 10.66 & & \\
\hline Kolikyeganskoye & 13.24 & 5.01 & & \\
\hline Kolikyeganskoye Vostochnoye & 11.17 & 6.87 & & \\
\hline Kolotuchnoye & 293.43 & 110.92 & & \\
\hline Kondakovskoye (Tomsk) & 9.43 & 4.45 & & \\
\hline Kondinskoye Vostochnoye & 11.17 & 6.87 & & \\
\hline Koshilsko-Vakhskoye & 388.68 & 239.04 & & \\
\hline Krasnoyarskoye Zapadnoye & 16.12 & 6.09 & & \\
\hline Kulyeganskoye (Tomsk) & 19.52 & 5.08 & & \\
\hline Lomovoye & 118.92 & 66.41 & & \\
\hline Luginets Zapadnoye & 11.17 & 6.87 & & \\
\hline Luginetskoye & & & 386.86 & 11.33 \\
\hline Malo Kolikyeganskoye & 11.17 & 6.87 & & \\
\hline Mirnoye & & & 861.53 & 25.24 \\
\hline Mykhlorskoye & 3.89 & 1.10 & & \\
\hline Myldzhinskoye Yuzhnoye & 35.00 & 9.97 & & \\
\hline Myldzhinskoye & & & $8,959.91$ & 199.55 \\
\hline Nazinskoye Yuzhnoye & 17.75 & 3.73 & & \\
\hline Nikol'skoye (Tomsk) & 9.40 & 2.88 & & \\
\hline Nikol'skoye (Tyumen) & 11.17 & 6.87 & & \\
\hline Nizhne-Tobolyanskoye & 1.13 & 0.12 & & \\
\hline Okhteurskoye Vostochnoye & 11.17 & 6.87 & & \\
\hline Okhteurskoye Yuzhnoye & 24.16 & 8.12 & & \\
\hline Ostaninskoye Zapadnoye & 14.27 & 6.73 & & \\
\hline Ostaninskoye Severnoye & 4.89 & 2.54 & & \\
\hline Ostaninskoye & 76.80 & 38.55 & $1,451.68$ & 52.48 \\
\hline Permyakovskoye & 150.44 & 30.42 & & \\
\hline Pindzhinskoye & 63.01 & 7.25 & & \\
\hline Pionerskoye & 11.17 & 6.87 & & \\
\hline Poludennoye Severnoye & 11.17 & 6.87 & & \\
\hline Poludennoye (Tomsk) & 74.80 & 18.48 & & \\
\hline Protochnoye & 49.63 & 9.53 & & \\
\hline Protochnoye Severnoye & 2.64 & 0.48 & & \\
\hline Protochnoye Yuzhnoye & 1.76 & 0.32 & & \\
\hline Puglalymskoye & 141.34 & 431.08 & & \\
\hline Rechnoye & & & 5.65 & 0.11 \\
\hline Rybalnoye & 19.77 & 7.47 & & \\
\hline
\end{tabular}


Table 18D. Calculated Crude Oil, Natural Gas, and Condensate Recovery by Field, Vasyugan Region, West Siberien Basin (Sorted Alphabetically by Field Name) (Continued)

\begin{tabular}{|c|c|c|c|c|}
\hline Field Name & $\begin{array}{l}\text { Ultimate } \\
\text { Crude Oil } \\
\text { (million } \\
\text { barrels) }\end{array}$ & $\begin{array}{l}\text { Associated- } \\
\text { Disolved Gas } \\
\text { (billion } \\
\text { cubic feet) }\end{array}$ & $\begin{array}{l}\text { Nonassociated } \\
\text { Gas } \\
\text { (billion } \\
\text { cubic feet) } \\
\end{array}$ & $\begin{array}{l}\text { Condensate } \\
\text { (million } \\
\text { barrels) }\end{array}$ \\
\hline Selimkhanovskoye & 116.57 & 45.08 & 16.38 & 0.48 \\
\hline Severnoye & 241.61 & 80.63 & 782.87 & 15.54 \\
\hline Shinginskoye & 12.30 & 5.30 & & \\
\hline Siktorskoye Severnoye & 49.65 & 46.88 & & \\
\hline Sredne-Vasyuganskoye & 254.82 & 75.53 & 93.65 & 2.74 \\
\hline Srednenyurol'skoye & 132.64 & 23.88 & & \\
\hline Stavropolskoye & 2.00 & 1.00 & & \\
\hline Tul'yeganskoye & 3.38 & 2.08 & & \\
\hline Tungolskoye & 6.30 & 1.68 & & \\
\hline Vakh Severnoye & 0.71 & 0.27 & & \\
\hline Vakh River & 38.57 & 12.65 & & \\
\hline Vakh Yuzhnoye & 32.01 & 6.80 & & \\
\hline Vartovskoye & 6.03 & 57.51 & & \\
\hline Vasyuganskoye Severnoye & & & 390.18 & 1.95 \\
\hline Verkhne-Salatskoye & 17.19 & 24.95 & 49.35 & 1.45 \\
\hline Verkhnekambarskoye & & & 932.95 & 18.86 \\
\hline Vonterskoye & 80.62 & 122.22 & & \\
\hline TOTAL & $3,918.65$ & $2,155.35$ & $14,152.78$ & 334.17 \\
\hline
\end{tabular}

Notes: Alternate field names or combinations in parenthesis.

Source: Energy Information Administration, Office of Oil and Gas. 
Table 19D. Basic Field Information, Paydugan Region, West Siberian Basin (Sorted Alphabetically by Field Name)

\begin{tabular}{lccccc}
\hline Field Name & $\begin{array}{c}\text { North } \\
\text { Latitude } \\
\text { (degrees) }\end{array}$ & $\begin{array}{c}\text { East } \\
\text { Latitude } \\
\text { (degrees) }\end{array}$ & $\begin{array}{c}\text { Discovery } \\
\text { Date }\end{array}$ & $\begin{array}{c}\text { Producing } \\
\text { Status }\end{array}$ & $\begin{array}{c}\text { Primary } \\
\text { Product }\end{array}$ \\
\hline Beloyarskoye & & & & & \\
Dvoynoye & 58.68 & 80.06 & 1962 & SI & Gas \\
Kiyevyeganskoye & 58.83 & 79.45 & 1986 & SI & Oil \\
Lineynoye & 60.11 & 80.84 & 1970 & SI & Oil \\
Sil'ginskoye Severnoye & 60.57 & 80.50 & 1972 & SI & Oil \\
Snezhnoye & 58.94 & 80.12 & 1971 & SI & Gas \\
Sobolinoye & 58.97 & 79.78 & 1983 & SI & Oil \\
Srednesil'ginskoye & 58.46 & 79.53 & 1967 & PP & Oil \\
Ust'-Sil'ginskoye & 58.87 & 80.14 & 1962 & SI & Gas \\
Varyngskoye & 58.87 & 80.00 & 1961 & SI & Gas \\
& 62.67 & 80.17 & & SI & Oil
\end{tabular}

Notes: PP=Producing Primary, PS=Producing Secondary, DV=Developing, $S \mid=S h u t ~ I n, A B N D=A b a n d o n e d$. Alternate field names or combined field names in parenthesis.

Source: Energy information Administration, Office of Oil and Gas. 
Table 20D. Calculated Crude Oil, Natural Gas, and Condensate Recovery by Field, Paydugan Region, West Siberian Basin (Sorted Alphabetically by Field Name)

\begin{tabular}{lcccc}
\hline & $\begin{array}{c}\text { Ultimate } \\
\text { Crude Oil } \\
\text { (million } \\
\text { barrels) }\end{array}$ & $\begin{array}{c}\text { Associated- } \\
\text { Disolved Gas } \\
\text { (billion } \\
\text { cubic feet) }\end{array}$ & $\begin{array}{c}\text { Nonassociated } \\
\text { Gas } \\
\text { (billion } \\
\text { cubic feet) }\end{array}$ & $\begin{array}{c}\text { Condensate } \\
\text { (million } \\
\text { barrels) }\end{array}$ \\
\hline $\begin{array}{l}\text { Beld Name } \\
\text { Beloyarskoye }\end{array}$ & & & & \\
$\begin{array}{l}\text { Dvoynoye } \\
\text { Kiyevyeganskoye }\end{array}$ & 5.01 & 1.89 & 65.27 & 1.91 \\
$\begin{array}{l}\text { Lineynoye } \\
\text { Sil'ginskoye Severnoye }\end{array}$ & 19.95 & 8.84 & & \\
$\begin{array}{l}\text { Snezhnoye } \\
\text { Sobolinoye }\end{array}$ & 6.77 & 2.10 & & \\
$\begin{array}{l}\text { Srednesil'ginskoye } \\
\text { Ust'-Sil'ginskoye }\end{array}$ & 37.04 & 14.00 & 244.63 & 7.17 \\
Varyngskoye & 183.05 & 28.56 & & \\
& & & 40.39 & 0.32 \\
TOTAL & 97.64 & 36.91 & 489.43 & 11.26 \\
& 349.46 & 92.30 & & \\
\end{tabular}

Notes: Alternate field names or combinat ons in parenthesis.

Source: Energy Information Administration, Office of Oil and Gas. 
Table 21D. Basic Field Information, Middle Ob Region, West Siberian Basin (Sorted Alphabetically by Field Name)

\begin{tabular}{|c|c|c|c|c|c|}
\hline Field Name & $\begin{array}{c}\text { North } \\
\text { Latitude } \\
\text { (degrees) }\end{array}$ & $\begin{array}{c}\text { East } \\
\text { Latitude } \\
\text { (degrees) }\end{array}$ & $\begin{array}{c}\text { Discovery } \\
\text { Date }\end{array}$ & $\begin{array}{l}\text { Producing } \\
\text { Status }\end{array}$ & $\begin{array}{l}\text { Primary } \\
\text { Product }\end{array}$ \\
\hline Achimovskoye (Achimov) & 60.07 & 75.34 & 1981 & $\mathrm{SI}$ & Oil \\
\hline Aganskoye & 61.47 & 76.02 & 1965 & PS & Oil \\
\hline Aganskoye Yuzhnoye & 61.30 & 75.88 & 1980 & PS & Oil \\
\hline Aganskoye Zapadnoye & 61.45 & 77.02 & 1981 & PP & Oil \\
\hline Alekhinskoye & 62.16 & 71.88 & 1971 & PS & Oil \\
\hline Alenkinskoye & 60.43 & 77.21 & 1964 & SI & Oil \\
\hline Asomkinskoye & 61.01 & 73.84 & 1981 & PS & Oil \\
\hline Asomkinskoye Vostochnoye & 61.30 & 75.83 & 1990 & SI & Oil \\
\hline Asomkinskoye Yuzhnoye & 60.91 & 73.88 & 1988 & DV & Oil \\
\hline Asomkinskoye Zapadnoye & 60.90 & 73.51 & 1988 & SI & Oil \\
\hline Aypim Lobat-Yugan (Ai Pim) & 62.23 & 71.14 & 1971 & PP & Oil \\
\hline Balykskoye Yuzhnoye & 60.50 & 72.50 & 1964 & PS & Oil \\
\hline Bittemskoye & 61.92 & 71.23 & 1989 & $\mathrm{SI}$ & Oil \\
\hline Boloshekotukhtinskoye(Kotukhta) & & & 1972 & si & Oil \\
\hline Bystrinskoye (Bystrin) & 61.46 & 72.24 & 1964 & PS & Oil \\
\hline Chakhloneyskoye & 60.52 & 75.80 & 1988 & DV & Oil \\
\hline Chernogorskoye & 61.50 & 76.67 & 1972 & PP & Oil \\
\hline Chistinnoye & 59.82 & 75.99 & 1985 & SI & Oil \\
\hline Chukhlorskoye & 61.87 & 76.53 & 1989 & SI & Oll \\
\hline Chumpaskoye & 61.25 & 75.11 & 1979 & PS & Oil \\
\hline Chupal'skoye & 60.15 & 72.45 & 1971 & DV & Oil \\
\hline Chupal'skoye Severnoye & 60.29 & 72.68 & 1977 & SI & Oil \\
\hline Druzhnoye & 62.45 & 74.62 & 1982 & PS & Oil \\
\hline Dunayevskoye & 61.62 & 73.20 & 1986 & PS & Oil \\
\hline Fainskoye & 61.10 & 73.75 & 1989 & PP & Oil \\
\hline Fedorovskoye & 61.39 & 73.12 & 1971 & PS & Oil \\
\hline Fobosskoye & 60.87 & 77.62 & 1988 & DV & Oil \\
\hline Golevoye & 61.71 & 76.25 & 1988 & SI & Oil \\
\hline Gribnoye & 62.56 & 74.86 & 1982 & DV & Oil \\
\hline Gun-Yeganskoye & 61.62 & 77.44 & 1973 & PS & Oil \\
\hline Ikilorskoye & 62.11 & 73.93 & 1981 & SI & Oil \\
\hline Imlorskoye & 63.00 & 73.87 & & SI & Oil \\
\hline Imlorskoye Zpapadnoye & 62.97 & 73.50 & & Si & Oil \\
\hline Istochnoye & 63.17 & 73.83 & & SI & Oil \\
\hline Kamynskoye & 62.17 & 71.62 & 1982 & PS & Oil \\
\hline Kamynskoye Severnoye & 62.29 & 70.79 & 1989 & SI & Oil \\
\hline Kamynskoye Yuzhnoye & 61.80 & 70.50 & 1989 & SI & Oil \\
\hline Karamovskoye & 63.25 & 74.44 & 1975 & PS & Oil \\
\hline Karamovskoye Severnoye & 63.31 & 74.58 & 1975 & PP & Oil \\
\hline Karyaunskoye & 62.03 & 72.27 & 1980 & $\mathrm{SI}$ & Oil \\
\hline Kechimovskoye & 61.80 & 74.50 & & SI & Oil \\
\hline Kechimovskoye Yuzhnoye & 61.17 & 74.37 & & SI & Oil \\
\hline Ketovskoye & 60.85 & 75.13 & 1980 & PS & Oil \\
\hline Khokhlovskoye & 60.90 & 76.25 & 1987 & SI & Oil \\
\hline Kholmogoryskoye & 62.94 & 74.35 & 1973 & PS & Oil \\
\hline Khorlorskoye & 62.89 & 71.52 & 1993 & SI & Oil \\
\hline Khorlorskoye Verkhniy & & & 1994 & SI & Oil \\
\hline Khulymskoye Yuzhnoye & 64.25 & 70.72 & 1986 & $\mathrm{SI}$ & Oil \\
\hline Khvoynoye & 60.12 & 77.24 & 1984 & PP & Oil \\
\hline Kinyaminskoye Yuzhnoye & 60.37 & 74.92 & 1990 & SI & Oil \\
\hline Kinyaminskoye & & & 1990 & SI & Oil \\
\hline
\end{tabular}


Table 21D. Basic Field Informatior।, Middle Ob Region, West Siberian Basin (Sorted Alphabetically lsy Field Name) (Continued)

\begin{tabular}{|c|c|c|c|c|c|}
\hline Field Name & $\begin{array}{c}\text { North } \\
\text { Latitude } \\
\text { (degrees) }\end{array}$ & $\begin{array}{l}\text { East } \\
\text { Latitude } \\
\text { (degrees) }\end{array}$ & $\begin{array}{c}\text { Discovery } \\
\text { Date }\end{array}$ & $\begin{array}{l}\text { Producing } \\
\text { Status }\end{array}$ & $\begin{array}{l}\text { Primary } \\
\text { Product }\end{array}$ \\
\hline Kochevskoye Severnoye & 62.68 & 73.43 & & PP & Oil \\
\hline Kochevskoye(Tevlin-Konitlor) & 62.50 & 73.40 & 1979 & PS & Oil \\
\hline Kogolymskoye & 62.44 & 73.79 & 1972 & PS & Oil \\
\hline Kogolymskoye Severnoye & 62.74 & 73.86 & 1984 & $\mathrm{SI}$ & Oil \\
\hline Kogolymskoye Yuzhnoye & 62.37 & 73.95 & 1972 & $\mathrm{SI}$ & Oil \\
\hline Komar'inskoye & 61.48 & 72.13 & 1971 & PS & Oil \\
\hline Konitlorskoye Severnoye & 62.70 & 72.79 & 1986 & $\mathrm{SI}$ & Oil \\
\hline Konitlorskoye Vostochnoye & 62.50 & 72.80 & 1990 & $\mathrm{SI}$ & Oil \\
\hline Konitlorskoye Yuzhnoye & 62.15 & 72.83 & 1988 & SI & Oil \\
\hline Konitlorskoye Zapadnoye & 62.26 & 72.54 & 1989 & $\mathrm{SI}$ & Oil \\
\hline Konitlorskoye(Tevlin-Konitlor) & 62.50 & 72.80 & 1972 & $\mathrm{SI}$ & Oil \\
\hline Kotukhtaskoye Zapadnoye & 62.64 & 75.47 & 1981 & $\mathrm{SI}$ & Oil \\
\hline Kudrinskoye & 60.83 & 72.50 & 1990 & & Oil \\
\hline Kul'yeganskoye (Tyumen) & 59.99 & 76.17 & 1986 & $\mathrm{SI}$ & Oil \\
\hline Kurraganskoye & 61.72 & 75.95 & 1980 & $\mathrm{SI}$ & Oil \\
\hline Kurraganskoye Yuzhnoye & 61.66 & 75.92 & 1988 & $\mathrm{SI}$ & Oil \\
\hline Kustovoye Yuzhnoye & 62.03 & 74.33 & 1986 & $\mathrm{SI}$ & Oil \\
\hline Kvartovoye & 60.05 & 77.08 & 1974 & SI & Oil \\
\hline Kysomskoye & 61.50 & 77.17 & 1987 & PP & Oil \\
\hline Larkinskoye & 62.13 & 72.42 & 1986 & $\mathrm{SI}$ & Oil \\
\hline Lasyeganskoye(Pokachev-Ur'yev) & 61.50 & 75.00 & 1979 & PS & Oil \\
\hline Ledovoye Severnoye (Tomsk & 59.62 & 76.77 & & SI & Oil \\
\hline Ledovoye (Tomsk) & 59.54 & 76.69 & 1972 & $\mathrm{SI}$ & Oil \\
\hline Ledyanoye & 59.66 & 76.15 & 1987 & SI & Oil \\
\hline \multicolumn{6}{|l|}{ Lempinskoye Zapadnoye } \\
\hline (Pravdinsk-Salym) & 60.83 & 71.42 & 1964 & SI & Oil \\
\hline Lokosovoskoye & 61.20 & 74.91 & 1963 & PS & Oil \\
\hline Loryeganskoye & 61.44 & 77.04 & 1980 & PS & Oil \\
\hline Losevoyeskoye & 62.84 & 71.85 & 1987 & $\mathrm{SI}$ & Oil \\
\hline Lyantorskoye (Taybinskoye) & 61.54 & 72.11 & 1966 & PS & Oil \\
\hline Malo-Aganskoye Yuzhnoye & 61.45 & 76.02 & 1980 & PP & Oil \\
\hline Malo-Perevalnoye & 63.25 & 72.62 & 1991 & SI & Oil \\
\hline Malobalykskoye & 60.48 & 72.25 & 1966 & PS & Oil \\
\hline Malochernogorskoye & 61.49 & 77.20 & 1969 & PS & Oil \\
\hline Maloklyuchevoye & 61.59 & 75.83 & 1983 & SI & Oil \\
\hline Malokustovoye & 62.07 & 74.48 & 1986 & SI & Oil \\
\hline Maloledyanoye & 59.60 & 76.17 & 1989 & SI & Oil \\
\hline Malopokachevskoye & 61.81 & 75.19 & 1973 & SI & Oil \\
\hline Malopyakutaskoye & 63.70 & 73.28 & 1986 & SI & Oil \\
\hline Malorechenskoye & 60.52 & 77.24 & 1965 & PS & Oil \\
\hline Malovat'yeganskoye & 62.15 & 75.32 & 1984 & PP & Oil \\
\hline Maloyagunskoye & 62.30 & 74.30 & & $\mathrm{SI}$ & Oil \\
\hline Maloyuganskoye Severnoye & 60.20 & 75.10 & & SI & Oil \\
\hline Maloyuganskoye & 60.19 & 75.18 & 1975 & SI & Oil \\
\hline Mamontovskoye(Ust-Balyk) & 61.09 & 72.57 & 1965 & PS & Oil \\
\hline Maslikhovskoye & 61.70 & 71.64 & 1985 & PS & Oil \\
\hline Matyushkinskoye & 59.89 & 76.98 & 1969 & SI & Oil \\
\hline Mayskoye & 60.41 & 72.80 & 1978 & PS & Oil \\
\hline Megionskoye & 61.13 & 76.00 & 1964 & PS & Oil \\
\hline Minchimkaskoye & 61.88 & 72.87 & 1969 & SI & Oil \\
\hline Minchimkaskoye Severnaya & 61.92 & 72.67 & 1969 & SI & Oil \\
\hline
\end{tabular}


Table 21D. Basic Field Information, Middle Ob Region, West Siberian Basin (Sorted Alphabetically by Field Name) (Continued)

\begin{tabular}{|c|c|c|c|c|c|}
\hline Field Name & $\begin{array}{c}\text { North } \\
\text { Latitude } \\
\text { (degrees) }\end{array}$ & $\begin{array}{l}\text { East } \\
\text { Latitude } \\
\text { (degrees) }\end{array}$ & $\begin{array}{c}\text { Discovery } \\
\text { Date }\end{array}$ & $\begin{array}{l}\text { Producing } \\
\text { Status } \\
\end{array}$ & $\begin{array}{l}\text { Primary } \\
\text { Product } \\
\end{array}$ \\
\hline Mogutlorskoye & 62.03 & 75.82 & 1987 & SI & Oil \\
\hline Mogutlorskoye Zapadnoye & 62.02 & 75.65 & 1986 & PP & Oil \\
\hline Mokhovoye Vostochnoye & 61.88 & 74.34 & 1973 & SI & Oil \\
\hline Mokhtikovskoye & 60.44 & 76.58 & 1988 & SI & Oil \\
\hline Mykhpayskoye(Samotlor) & 61.20 & 76.60 & 1961 & PS & Oil \\
\hline Nezhdannoye & 60.43 & 76.87 & 1981 & SI & Oil \\
\hline Nivagalskoye(Pokachev-Ur'yev) & 61.66 & 74.80 & 1968 & PS & Oil \\
\hline Nizhne-Shapshinskoye & 60.50 & 70.33 & & SI & Oil \\
\hline Nizhne-Sortymskoye & 62.48 & 71.68 & 1974 & PS & Oil \\
\hline Nizhnevartovskoye & 60.80 & 77.10 & 1965 & PP & Oil \\
\hline Nong'yeganskoye & 61.89 & 74.86 & 1974 & PS & Oil \\
\hline Nong'yeganskoye Vostochnoye & 61.84 & 75.01 & 1974 & SI & Oil \\
\hline Novopokurskoye & 60.75 & 74.50 & 1981 & PS & Oil \\
\hline Noyabr'skoye Zapadnoye & 63.39 & 75.01 & 1987 & PS & Oil \\
\hline Ob River Area & & & 1982 & SI & Oil \\
\hline Ombinskoye & 61.05 & 72.83 & 1989 & PP & Oil \\
\hline Orekhovskoye Severnoye & 61.00 & 76.23 & & SI & Oil \\
\hline Orekhovoskoye & 60.82 & 75.70 & 1976 & SI & Oil \\
\hline Osomkinskoye Zapadnoye & 61.00 & 73.55 & & SI & Oil \\
\hline Ostrovnoye & 60.93 & 75.18 & 1980 & SI & Oil \\
\hline Ostrovnoye Severnoye & 61.01 & 74.84 & 1978 & PP & Oil \\
\hline Ostrovnoye Yuzhnoye & 60.75 & 74.92 & 1989 & SI & Oil \\
\hline Otdelnoye & 62.93 & 74.86 & 1985 & SI & Oil \\
\hline Pal'nikovskoye & 64.63 & 72.18 & 1992 & SI & Oil \\
\hline Pereval'noye Vostochnoye & 63.26 & 72.63 & 1990 & SI & Oil \\
\hline Perevalnoye Yuzhnoye & & & 1991 & SI & Oil \\
\hline Petelinskoye & 60.55 & 71.92 & 1982 & PS & Oil \\
\hline Pil'tanskoye & 61.68 & 73.15 & 1985 & PP & Oil \\
\hline Pogranichnoye (Tyumen) & 62.91 & 75.19 & 1982 & PS & Oil \\
\hline \multicolumn{6}{|c|}{$\begin{array}{l}\text { Pokachevsko-Ur'yevskoye (Akhskoye, } \\
\text { Lasyeganskoye, Nivagalskoye, } \\
\text { Potochnoye, Potochnoye Severnoye, } \\
\text { Pokachevskove Yuzhnoye, }\end{array}$} \\
\hline Ur'yevskoye) & 61.73 & 75.23 & 1970 & PS & Oil \\
\hline \multicolumn{6}{|l|}{ Pokachevskoye Severnoye } \\
\hline (Pokachev-Úr'yev) & 61.89 & 75.56 & 1980 & PP & Oil \\
\hline Pokachevskoye Vostochnoye & 61.85 & 75.90 & 1980 & $\mathrm{SI}$ & Oil \\
\hline \multicolumn{6}{|l|}{ Pokachevskoye Yuzhnoye } \\
\hline (Pokachev-Úr'yev) & 61.64 & 75.33 & 1976 & PP & Oil \\
\hline Pokamasovskoye & 61.20 & 74.39 & 1972 & PS & Oil \\
\hline Pokamasovskoye Yuzhnoye & 61.07 & 74.50 & & SI & Oil \\
\hline Pokamasovskoye Zapadnoye & 61.32 & 74.40 & & SI & Oil \\
\hline Pokurskoye Severskoye & 61.20 & 75.50 & 1964 & PS & Oil \\
\hline Poludennoye (Tyumen) & 60.54 & 76.64 & 1983 & PP & Oil \\
\hline Pomaliyakhskoye Severnoye & 64.08 & 74.25 & 1989 & PP & Oil \\
\hline Potochnoye Severnoye(Poka-Ury) & & & 1979 & SI & Oil \\
\hline Potochnoye(Poka-Ury) & & & 1974 & SI & Oil \\
\hline Povkhovskoye & 62.36 & 75.81 & 1972 & PS & Oil \\
\hline Povkhovskoye Severnoye & 62.80 & 76.20 & & SI & Oil \\
\hline Povkhovskoye Yuzhnoye & 62.39 & 76.19 & 1972 & SI & Oil \\
\hline Pravdinsk-Salymskoye & 60.94 & 71.78 & 1964 & PS & Oil \\
\hline
\end{tabular}


Table 21D. Basic Field Information, Middle Ob Region, West Siberian Basin (Sorted Alphabetically by Field Name) (Continued)

\begin{tabular}{|c|c|c|c|c|c|}
\hline Field Name & $\begin{array}{c}\text { North } \\
\text { Latitude } \\
\text { (degrees) }\end{array}$ & $\begin{array}{l}\text { East } \\
\text { Latitude } \\
\text { (degrees) }\end{array}$ & $\begin{array}{c}\text { Discovery } \\
\text { Date }\end{array}$ & $\begin{array}{l}\text { Producing } \\
\text { Status }\end{array}$ & $\begin{array}{l}\text { Prima } \\
\text { Prode }\end{array}$ \\
\hline Pridorozhnoye Vostochnoye & 62.10 & 74.67 & & SI & Oil \\
\hline Promezhutochnoye & 61.33 & 71.50 & & SI & Oil \\
\hline Pyakutaskoye & 63.74 & 73.10 & 1987 & SI & Oil \\
\hline Pyakutaskoye Vostochnoye & 63.58 & 74.14 & 1982 & DV & Oil \\
\hline Pylinskoye & 61.05 & 77.54 & 1980 & PP & Oil \\
\hline Pylinskoye Zapadnoye & 61.05 & 77.50 & 1991 & $\mathrm{SI}$ & Oil \\
\hline Ravenskoye & 61.90 & 74.17 & 1981 & SI & Oil \\
\hline Rodnikovoye & 61.73 & 74.25 & 1988 & PP & Oil \\
\hline Romanovskoye & 63.80 & 73.89 & 1987 & SI & Oil \\
\hline Roslavlskoye & 62.03 & 76.48 & 1988 & DV & Oil \\
\hline Rubinovoye & 61.13 & 76.28 & 1982 & PP & Oil \\
\hline Ruf'yeganskoye & 61.30 & 77.59 & 1982 & PP & Oil \\
\hline Russkinskoye(Tevlin-Konit.) & & & 1982 & SI & Oil \\
\hline Ryamnoye & 60.91 & 76.75 & 1989 & DV & Oil \\
\hline Sakhalinskoye (Tyumen) & 61.41 & 71.03 & 1983 & SI & Oil \\
\hline Sakhalinskoye Vostochnoye & 61.51 & 71.28 & 1984 & SI & Oil \\
\hline Salymskoye & 60.00 & 71.00 & 1965 & DV & Oil \\
\hline Salymskoye Central (Srednesalym) & 60.00 & 71.00 & 1967 & PS & Oil \\
\hline Salymskoye Severnny & 60.00 & 71.00 & 1978 & PS & Oil \\
\hline Salymskoye Vostochnoye & 60.20 & 71.18 & 1989 & SI & Oil \\
\hline Salymskoye Zapadnoye & 60.31 & 70.93 & 1987 & SI & Oil \\
\hline \multicolumn{6}{|l|}{$\begin{array}{l}\text { Samotlorskoye (Vata, Megion, } \\
\text { Pokur Sev., }\end{array}$} \\
\hline Mykhpay, Orekhovo Sev.) & 60.95 & 76.37 & 1961 & PS & Oil \\
\hline Saporkinskoye & 61.72 & 72.18 & 1982 & SI & Oil \\
\hline Sardakovskoye Yuzhnoye & 62.18 & 76.19 & 1989 & SI & Oil \\
\hline Savuyskoye & 61.88 & 73.78 & 1971 & PS & Oil \\
\hline Saygataskoye & 61.27 & 72.89 & 1966 & PS & Oil \\
\hline Shapshinskoye & 60.40 & 70.30 & 1981 & DV & Oil \\
\hline Shchuch'yeskoye & 61.79 & 76.88 & 1986 & SI & Oil \\
\hline Shirokovskoye & 61.39 & 74.05 & 1977 & DV & Oil \\
\hline Soimlorskoye Severnoye & 63.34 & 73.83 & 1981 & DV & Oil \\
\hline Sokhtymskoye & 62.50 & 72.35 & 1990 & SI & Oll \\
\hline Solkinskoye Zapadnoye & 61.35 & 72.42 & 1976 & PP & Oil \\
\hline Sorominskoye & 61.20 & 77.36 & 1971 & PS & Oil \\
\hline Sorominskoye Severnoye & 61.23 & 77.42 & 1971 & SI & Oil \\
\hline Sorominskoye Zapadnoye & 61.26 & 77.36 & 1971 & SI & Oil \\
\hline Sortymskoye & 62.40 & 71.70 & 1992 & SI & Oll \\
\hline Sorymskoye & & & 1982 & Si & Oil \\
\hline Sovetskoye & & & 1962 & DV & Oil \\
\hline Sredne Khulymskoye & 64.55 & 71.29 & 1989 & SI & Oil \\
\hline Sredne-Iterskoye & 63.50 & 74.67 & & SI & Oil \\
\hline Sredne-Shapshinskoye & 60.67 & 70.33 & & SI & Oil \\
\hline Sredne-Vatlorskoye & 63.19 & 71.41 & 1988 & SI & Oil \\
\hline Sredneasomkinskoye & 61.00 & 73.00 & 1987 & PS & Oil \\
\hline Srednebalykskoye & 60.53 & 72.52 & 1965 & PS & Oil \\
\hline Srednechernogorskoye & 61.41 & 76.78 & 1986 & SI & Oil \\
\hline Sredneugutskoye & 60.50 & 73.97 & 1988 & $\mathrm{SI}$ & \\
\hline Strezhevoye & 60.79 & 77.46 & 1968 & PS & \\
\hline Strezhevoye Vostochnoye & & & & SI & \\
\hline Studenoye & 61.84 & 70.93 & 1975 & SI & Oil \\
\hline
\end{tabular}


Table 21D. Basic Field Information, Middle Ob Region, West Siberian Basin (Sorted Alphabetically by Field Name) (Continued)

\begin{tabular}{|c|c|c|c|c|c|}
\hline Field Name & $\begin{array}{c}\text { North } \\
\text { Latitude } \\
\text { (degrees) }\end{array}$ & $\begin{array}{c}\text { East } \\
\text { Latitude } \\
\text { (degrees) }\end{array}$ & $\begin{array}{c}\text { Discovery } \\
\text { Date }\end{array}$ & $\begin{array}{c}\text { Producing } \\
\text { Status }\end{array}$ & $\begin{array}{l}\text { Primary } \\
\text { Product }\end{array}$ \\
\hline Sugmutskoye & 63.84 & 73.64 & 1987 & SI & Oil \\
\hline Surgutskoye Severnoye & 61.74 & 73.44 & 1963 & PS & Gas \\
\hline \multicolumn{6}{|l|}{ Surgutskoye Vostochnny } \\
\hline (Federovo-Surgut) & 61.70 & 73.40 & 1977 & SI & Oil \\
\hline Surgutskoye Yuzhnny(Federovo) & 61.70 & 73.40 & 1973 & PS & Oil \\
\hline \multicolumn{6}{|l|}{ Surgutskoye Zapadnoye } \\
\hline (Federovo-Surgut) & 61.70 & 73.40 & 1962 & PS & Oil \\
\hline Sutorlinskoye & 61.30 & 73.50 & 1975 & DV & Oil \\
\hline Taplorskoye & 61.92 & 72.67 & 1978 & $\mathrm{SI}$ & Oil \\
\hline Tarkhovskoye Severnoye & 61.17 & 77.20 & 1981 & SI & Oil \\
\hline Tarkhovskoye Yuzhnoye & 61.10 & 77.07 & 1981 & SI & Oil \\
\hline Tarkhovskoye Zapadnoye & 61.11 & 77.08 & 1987 & SI & Oil \\
\hline Taybinskoye (Lyantor) & 61.87 & 72.13 & 1968 & SI & Gas \\
\hline Teplin-Russkinskoye & 62.25 & 73.50 & 1990 & PP & Oil \\
\hline Teplovskoye & 60.76 & 72.47 & 1966 & PS & Oil \\
\hline Tevlin-Konitlorskoye & 62.50 & 73.68 & 1971 & PS & Oil \\
\hline Tevlinskoye & 62.51 & 73.65 & 1972 & SI & Oil \\
\hline Tochinskoye & 62.18 & 72.25 & 1989 & SI & Oil \\
\hline Tonchinskoye & & & 1989 & SI & Oil \\
\hline Trom-Yeganskoye & 63.00 & 71.86 & 1986 & SI & Oil \\
\hline Trom-Yeganskoye Severnoye & 63.40 & 71.50 & 1993 & SI & Oil \\
\hline Trom-Yeganskoye Vostochnoye & 61.37 & 74.57 & 1988 & SI & Oil \\
\hline Tundrinskoye & 61.27 & 72.08 & 1981 & SI & Oil \\
\hline Tutlimskoye (Tutlimskoye)(Tutlym) & 62.05 & 72.07 & 1966 & DV & Oil \\
\hline Tyanovskoye & 62.98 & 72.34 & 1986 & DV & Oil \\
\hline Tyumenskoye & 61.65 & 77.62 & 1971 & PS & Oil \\
\hline Udachnoye & 60.50 & 71.83 & & SI & Oil \\
\hline Ugutskoye & 60.49 & 74.13 & 1985 & PS & Oil \\
\hline Ugutskoye Zapadnoye & 60.46 & 73.73 & 1984 & PP & Oil \\
\hline \multicolumn{6}{|l|}{ Uryevskoye(-Potochnoye) } \\
\hline (Pokachev-Ur'yev) & 61.42 & 75.45 & 1971 & PS & Oil \\
\hline Ust-Balykskoye Zapadnoye & 61.10 & 72.35 & 1985 & SI & Oil \\
\hline Ust-Balykskoye-Mamontovo & 61.09 & 72.57 & 1961 & PS & Oil \\
\hline Ust-Kotukhtinskoye & 62.50 & 76.00 & 1990 & SI & Oil \\
\hline Ust-Koyukhtaskoye & & & & SI & Oil \\
\hline Vachimskoye & 61.81 & 72.62 & 1971 & PS & Oil \\
\hline Vadelypskoye & 60.15 & 71.06 & 1989 & SI & Oil \\
\hline Vartov-Sovetskoye & 60.81 & 77.09 & 1962 & PS & Oil \\
\hline Vartovskoye-Sosinoskoye & 60.77 & 77.35 & 1962 & DV & Oil \\
\hline Vat'yeganskoye & 62.15 & 75.32 & 1970 & PP & Oil \\
\hline Vat'yeganskoye Severnoye & 62.40 & 75.30 & 1983 & SI & Oil \\
\hline Vat'yeganskoye Yuzhnoye & 62.03 & 75.02 & 1971 & DV & Oil \\
\hline Vataskoye & 61.17 & 75.78 & & SI & Oil \\
\hline Vataskoye Severnaya & 61.20 & 75.80 & 1980 & PP & Oil \\
\hline Vatinskoye & 61.25 & 75.90 & 1964 & PS & Oil \\
\hline Verkhne Nadymskoye & 63.40 & 72.88 & 1992 & SI & Oil \\
\hline Verkhnesalymskoye & 59.99 & 70.97 & 1966 & DV & Oil \\
\hline Verkhneshapshinskoye & 60.82 & 70.34 & 1972 & SI & Oil \\
\hline Verkhniy Kazymskoye & 63.60 & 70.93 & 1990 & SI & Oil \\
\hline Vershinnoye & 61.57 & 73.07 & 1964 & DV & Oil \\
\hline Vladigorskoye Yuzhnoye & 60.50 & 71.50 & & SI & Oil \\
\hline
\end{tabular}


Table 21D. Basic Field Information, Middle Ob Region, West Siberian Basin (Sorted Alphabetically by Field Name) (Continued)

\begin{tabular}{lccccc}
\hline Field Name & $\begin{array}{c}\text { North } \\
\text { Latitude } \\
\text { (degrees) }\end{array}$ & $\begin{array}{c}\text { East } \\
\text { Latitude } \\
\text { (degrees) }\end{array}$ & $\begin{array}{c}\text { Discovery } \\
\text { Date }\end{array}$ & $\begin{array}{c}\text { Producing } \\
\text { Status }\end{array}$ & $\begin{array}{c}\text { Primary } \\
\text { Product }\end{array}$ \\
\hline Vyintoyskoye & 62.90 & 75.78 & 1982 & SI & Oil \\
Vyintoyskoye Vostochnoye & 62.86 & 75.93 & 1989 & SI & Oil \\
Vyintoyskoye Yuzhnoye & 62.80 & 75.80 & 1988 & SI & Oil \\
XXVII CPSU Congress & 60.68 & 74.53 & & SI & Oil \\
Yagunskoye & 62.36 & 74.32 & 1978 & PS & Oil \\
Yagunskoye Severnoye & 62.70 & 74.45 & 1982 & DV & Oil \\
Yagunskoye Vostochnoye & 62.16 & 74.34 & 1982 & SI & Oil \\
Yagunskoye Yuzhnoye & 62.20 & 74.30 & 1979 & PS & Oil \\
Yamskoye & 60.33 & 71.50 & & SI & Oil \\
Yaunlorskoye & 61.52 & 72.93 & 1967 & PS & Oil \\
Yefremovoskoye & 60.60 & 73.00 & 1989 & PP & Oil \\
Yegur'yakhskoye & 61.72 & 76.40 & 1988 & SI & Oil \\
Yegur'yakhskoye Severnoye & 61.77 & 76.31 & 1987 & SI & Oil \\
Yegur'yakhskoye Yuzhnoye & 61.70 & 76.27 & 1990 & SI & Oil \\
Yelovoye Vostochnoye & 61.37 & 74.09 & 1987 & PP & Oil \\
Yermakovoskoye & 60.79 & 76.09 & 1974 & PS & Oil \\
Yermakovoskoye Severnoye & 60.80 & 76.10 & & SI & Oil \\
Yershovskoye (Tyumen) & 61.13 & 77.79 & 1979 & PS & Oil \\
Yuganskoye & & & 1975 & SI & Oil \\
Yur'yevskoye Severnoye & 61.99 & 72.98 & 1988 & SI & Oil \\
Yuzhnoye-1 & 60.63 & 75.91 & 1986 & PP & Oil \\
Yuzhnoye-2 & 60.62 & 76.01 & 1987 & SI & Oil \\
& & & & &
\end{tabular}

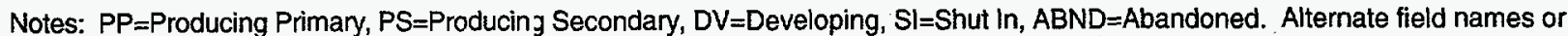
combined field names in parenthesis.

Source: Energy information Administration, Jffice of Oil and Gas. 
Table 22D. Calculated Crude Oil, Natural Gas, and Condensate Recovery by Field, Middle Ob Region, West Siberian Basin (Sorted Alphabetically by Field Name)

\begin{tabular}{|c|c|c|c|c|}
\hline Field Name & $\begin{array}{l}\text { Ultimate } \\
\text { Crude Oil } \\
\text { (million } \\
\text { barrels) } \\
\end{array}$ & $\begin{array}{l}\text { Associated- } \\
\text { Disolved Gas } \\
\text { (billion } \\
\text { cubic feet) } \\
\end{array}$ & $\begin{array}{l}\text { Nonassociated } \\
\text { Gas } \\
\text { (billion } \\
\text { cubic feet) } \\
\end{array}$ & $\begin{array}{c}\text { Condensate } \\
\text { (million } \\
\text { barrels) }\end{array}$ \\
\hline Achimovskoye (Achimov) & 210.42 & 62.75 & & \\
\hline Aganskoye & $1,792.72$ & 523.33 & & \\
\hline Aganskoye Zapadnoye & 1.53 & 0.48 & & \\
\hline Aganskoye Yuzhnoye & 12.74 & 4.00 & & \\
\hline Alekhinskoye & 651.33 & 194.60 & & \\
\hline Alenkinskoye & 11.37 & 3.24 & & \\
\hline Asomkinskoye Zapadnoye & 88.08 & 36.55 & & \\
\hline Asomkinskoye & 22.95 & 6.24 & & \\
\hline Asomkinskoye Vostochnoye & 7.56 & 2.81 & & \\
\hline Asomkinskoye Yuzhnoye & 10.40 & 2.83 & & \\
\hline Aypim Lobat-Yuganskoye (Ai Pim) & 486.10 & 61.94 & & \\
\hline Balykskoye Yuzhnoye & 317.37 & 93.10 & & \\
\hline Bittemskoye & 74.13 & 21.94 & & \\
\hline Boloshekotukhtinskoye(Kotukhta) & 19.90 & 5.23 & & \\
\hline Bystrinskoye (Bystrin) & $1,261.34$ & 250.17 & & \\
\hline Chakhloneyskoye & 2.37 & 0.74 & & \\
\hline Chernogorskoye & 199.52 & 74.97 & & \\
\hline Chistinnoye & 61.05 & 16.02 & & \\
\hline Chukhlorskoye & 22.13 & 8.94 & & \\
\hline Chumpaskoye & 205.63 & 52.93 & & \\
\hline Chupal'skoye Severnoye & 160.20 & 45.66 & & \\
\hline Chupal'skoye & 241.87 & 68.93 & & \\
\hline Druzhnoye & $1,354.11$ & 264.67 & & \\
\hline Dunayevskoye & 24.55 & 7.71 & & \\
\hline Fainskoye & 132.04 & 48.99 & & \\
\hline Fedorovskoye & $1,792.45$ & 808.46 & $1,133.65$ & 20.41 \\
\hline Fobosskoye & 38.07 & 12.60 & & \\
\hline Golevoye & 17.01 & 7.36 & & \\
\hline Gribnoye & 72.09 & 27.33 & & \\
\hline Gun-Yeganskoye & 98.13 & 38.04 & & \\
\hline Ikilorskoye & 250.18 & 86.82 & & \\
\hline Imlorskoye & 24.55 & 7.81 & & \\
\hline Imlorskoye Zpapadnny & 24.55 & 7.81 & & \\
\hline Istochnoye & 24.55 & 7.80 & & \\
\hline Kamynskoye Yuzhnoye & 60.66 & 19.09 & & \\
\hline Kamynskoye Severnoye & 254.88 & 80.14 & & \\
\hline Kamynskoye & 153.88 & 53.41 & & \\
\hline Karamovskoye Severnoye & 31.41 & 7.10 & & \\
\hline Karamovskoye & 383.90 & 81.84 & & \\
\hline Karyaunskoye & 3.82 & 1.09 & & \\
\hline Kechimovskoye & 24.55 & 7.81 & & \\
\hline Kechimovskoye Yuzhnoye & 24.55 & 7.81 & & \\
\hline Ketovskoye & 216.48 & 47.73 & & \\
\hline Khokhlovskoye & 6.24 & 2.47 & & \\
\hline Kholmogoryskoye & 722.86 & 190.78 & & \\
\hline Khorlorskoye Verkhniy & 24.55 & 7.73 & & \\
\hline Khorlorskoye & 41.05 & 11.70 & & \\
\hline Khulymskoye Yuzhnoye & 69.33 & 21.85 & & \\
\hline Khvoynoye & 13.99 & 6.03 & & \\
\hline Kinyaminskoye Yuzhnoye & 9.35 & 4.09 & & \\
\hline
\end{tabular}


Table 22D. Calculated Crude Oil, Natural Gas, and Condensate Recovery by Field, Middle Ob Region, West Siberian Basin (Sorted Alphabetically by Field Name) (Continued)

\begin{tabular}{|c|c|c|c|c|}
\hline Field Name & $\begin{array}{l}\text { Ultimate } \\
\text { Crude Oil } \\
\text { (million } \\
\text { barrels) } \\
\end{array}$ & $\begin{array}{l}\text { Associated- } \\
\text { Disolved Gas } \\
\text { (billion } \\
\text { cubic feet) }\end{array}$ & $\begin{array}{l}\text { Nonassociated } \\
\text { Gas } \\
\text { (billion } \\
\text { cubic feet) } \\
\end{array}$ & $\begin{array}{l}\text { Condensate } \\
\text { (million } \\
\text { barrels) }\end{array}$ \\
\hline Kinyaminskoye & 2.00 & 1.00 & & \\
\hline Kochevskoye Severnoye & 24.55 & 7.74 & & \\
\hline Kochevskoye(Tevlin-Konitlor) & 128.88 & 40.61 & 135.51 & 2.44 \\
\hline Kogolymskoye Severnoye & 27.02 & 8.53 & & \\
\hline Kogolymskoye Yuzhnoye & 13.25 & 4.19 & & \\
\hline Kogolymskoye & 433.46 & 129.73 & & \\
\hline Komar'inskoye & 30.59 & 9.67 & & \\
\hline Konitlorskoye Zapadnoye & 100.93 & 31.92 & & \\
\hline Konitlorskoye Yuzhnoye & 818.68 & 373.08 & & \\
\hline Konitlorskoye Vostochnoye & 20.39 & 6.45 & & \\
\hline Konitlorskoye Severnoye & 221.37 & 107.95 & & \\
\hline Konitlorskoye(Tevlin-Konitlor) & 101.64 & 31.94 & & \\
\hline Kotukhtaskoye Zapadnoye & 93.80 & 29.65 & & \\
\hline Kudrinskoye & 10.39 & 2.96 & & \\
\hline Kul'yeganskoye (Tyumen) & 18.85 & 4.54 & & \\
\hline Kurraganskoye Yuzhnoye & 7.05 & 2.15 & & \\
\hline Kurraganskoye & 27.17 & 8.81 & & \\
\hline Kustovoye Yuzhnoye & 3.57 & 1.13 & & \\
\hline Kvartovoye & 80.38 & 8.68 & & \\
\hline Kysomskoye & 7.07 & 2.02 & & \\
\hline Larkinskoye & 35.68 & 11.26 & & \\
\hline Lasyeganskoye(Pokachev-Ur'yev) & 232.36 & 59.93 & & \\
\hline Ledovoye Severnoye (Tomsk) & 24.55 & 7.75 & & \\
\hline Ledovoye (Tomsk) & 21.43 & 7.95 & & \\
\hline Ledyanoye & 9.01 & 2.69 & & \\
\hline \multicolumn{5}{|l|}{ Lempinskoye Zapadno } \\
\hline (Pravdinsk-Salym) & 45.10 & 16.73 & & \\
\hline Lokosovoskoye & 565.99 & 143.64 & & \\
\hline Loryeganskoye & 27.29 & 3.86 & & \\
\hline Losevoye & 9.92 & 4.89 & & \\
\hline Lyantorskoye (Taybinskoye) & $2,321.63$ & 685.97 & & \\
\hline Malo-Perevalnoye & 24.55 & 7.75 & & \\
\hline Malo-Aganskoye Yuzhnoye & 5.61 & 1.77 & & \\
\hline Malobalykskoye & 537.35 & 130.98 & & \\
\hline Malochernogorskoye & 105.21 & 39.19 & & \\
\hline Maloklyuchevoye & 85.38 & 56.79 & & \\
\hline Malokustovoye & 6.12 & 1.93 & & \\
\hline Maloledyanoye & 23.47 & 4.89 & & \\
\hline Malopokachevskoye & 24.55 & 7.75 & & \\
\hline Malopyakuta & 67.29 & 21.27 & & \\
\hline Malorechenskoye & 198.18 & 94.12 & & \\
\hline Malovat'yeganskoye & 6.12 & 1.93 & & \\
\hline Maloyagunskoye & 24.55 & 7.75 & & \\
\hline Maloyuganskoye & 171.27 & 116.68 & & \\
\hline Maloyuganskoye Severnoye & 24.55 & 7.75 & & \\
\hline Mamontovskoye(Ust-Balyk) & 616.20 & 153.57 & & \\
\hline Maslikhovskove & 18.22 & 6.45 & & \\
\hline Matyushkinskoye & 8.64 & 2.20 & & \\
\hline Mayskoye & 123.41 & 35.78 & & \\
\hline Megionskoye & 630.17 & 193.79 & & \\
\hline
\end{tabular}


Table 22D. Calculated Crude Oil, Natural Gas, and Condensate Recovery by Field, Middle Ob Region, West Siberian Basin (Sorted Alphabetically by Field Name) (Continued)

\begin{tabular}{|c|c|c|c|c|}
\hline Field Name & $\begin{array}{l}\text { Ultimate } \\
\text { Crude Oil } \\
\text { (million } \\
\text { barrels) } \\
\end{array}$ & $\begin{array}{l}\text { Associated- } \\
\text { Disolved Gas } \\
\text { (billion } \\
\text { cubic feet) } \\
\end{array}$ & $\begin{array}{l}\text { Nonassociated } \\
\text { Gas } \\
\text { (billion } \\
\text { cubic feet) } \\
\end{array}$ & $\begin{array}{c}\text { Condensate } \\
\text { (million } \\
\text { barrels) }\end{array}$ \\
\hline Minchimkaskoye & 111.75 & 34.61 & & \\
\hline Minchimkaskoye Severnaya & 0.29 & 0.07 & & \\
\hline Mogutlorskoye Zapadnoye & 13.25 & 4.19 & & \\
\hline Mogutlorskoye & 17.84 & 5.64 & & \\
\hline Mokhovoye Vostochnoye & 91.64 & 21.46 & & \\
\hline Mokhtikovskoye & 23.67 & 9.23 & & \\
\hline Mykhpayskoye (Samotlor) & 304.48 & 86.03 & & \\
\hline Nezhdannoye & 4.37 & 1.62 & & \\
\hline Nivagalskoye(Pokachev-Ur'yev) & $1,487.92$ & 384.76 & & \\
\hline Nizhne-Sortymskoye & 161.42 & 48.68 & & \\
\hline Nizhne-Shapshinskoye & 24.55 & 7.82 & & \\
\hline Nizhnevartovskoye & 24.44 & 7.72 & & \\
\hline Nong'yeganskoye Vostochnoye & 25.49 & 8.05 & & \\
\hline Nong'yeganskoye & $1,337.97$ & 580.93 & & \\
\hline Novopokurskoye & 224.34 & 363.29 & & \\
\hline Noyabr'skoye Zapadnoye & 249.30 & 72.91 & & \\
\hline Ob River Area & 112.69 & 33.18 & & \\
\hline Ombinskoye & 22.20 & 8.24 & & \\
\hline Orekhovoskoye & 19.78 & 7.34 & & \\
\hline Orekhovskoye Severnoye & 24.55 & 7.82 & & \\
\hline Osomkinskoye Zapadnoye & 24.55 & 7.82 & & \\
\hline Ostrovnoye Yuzhnoye & 24.55 & 7.76 & & \\
\hline Ostrovnoye & 5.55 & 2.37 & & \\
\hline Ostrovnoye Severnoye & 8.03 & 1.46 & & \\
\hline Otdelnoye & 43.50 & 8.53 & & \\
\hline Pal'nikovskoye & 8.35 & 3.10 & & \\
\hline Pereval'noye Vostochnoye & 196.65 & 46.61 & & \\
\hline Perevalnoye Yuzhnoye & 24.55 & 7.76 & & \\
\hline Petelinskoye & 202.21 & 37.11 & & \\
\hline Piltanskoye & 24.55 & 7.76 & & \\
\hline Pogranichnoye (Tyumen) & 225.97 & 51.36 & & \\
\hline $\begin{array}{l}\text { Pokachevsko-Ur'yevskoye } \\
\text { (Akhskoye, Lasyeganskoye, } \\
\text { Nivagalskoye, Potochnoye, } \\
\text { Potochnoye Severnoye, } \\
\text { Pokachevskoye Yuzhnoye, }\end{array}$ & & & & \\
\hline Ur'yevskoye) & $5,281.87$ & $1,507.62$ & & \\
\hline $\begin{array}{l}\text { Pokachevskoye Severnoye } \\
\text { (Pokachev-Ur'yev) }\end{array}$ & & & & \\
\hline Pokachevskoye Vostochnoye & 16.82 & 5.32 & & \\
\hline $\begin{array}{l}\text { Pokachevskoye Yuzhnoye } \\
\text { (Pokachev-Ur'yev) }\end{array}$ & & & & \\
\hline Pokamasovskoye & 357.53 & 144.38 & & \\
\hline Pokamasovskoye Yuzhnoye & 24.55 & 7.81 & & \\
\hline Pokamasovskoye Zapadnoye & 24.55 & 7.81 & & \\
\hline Pokurskoye Severskoye & 398.12 & 79.43 & & \\
\hline Poludennoye (Tyumen) & 622.66 & 104.82 & & \\
\hline Pomaliyakhskoye Severnoye & 6.20 & 1.77 & & \\
\hline Potochnoye Severnoye (Poka-Ury) & 376.54 & 107.31 & & \\
\hline Potochnoye (Poka-Ury) & 337.15 & 84.66 & & \\
\hline
\end{tabular}


Table 22D. Calculated Crude Oil, Natural Gas, and Condensate Recovery by Field, Middle Ob Region, West Siberian Basin (Sorted Alphabetically by Field Name) (Continued)

\begin{tabular}{|c|c|c|c|c|}
\hline Field Name & $\begin{array}{l}\text { Ultimate } \\
\text { Crude Oil } \\
\text { (million } \\
\text { barrels) } \\
\end{array}$ & $\begin{array}{l}\text { Associated- } \\
\text { Disolved Gas } \\
\text { (billion } \\
\text { cubic feet) } \\
\end{array}$ & $\begin{array}{l}\text { Nonassociated } \\
\text { Gas } \\
\text { (billion } \\
\text { cubic feet) } \\
\end{array}$ & $\begin{array}{c}\text { Condensate } \\
\text { (million } \\
\text { barrels) }\end{array}$ \\
\hline Povkhovskoye & $2,100.71$ & 797.07 & & \\
\hline Povkhovskoye Severnoye & 24.55 & 7.76 & & \\
\hline Povkhovskoye Yuzhnoye & 24.55 & 7.76 & & \\
\hline Pravdinsk-Salymskoye & $2,255.19$ & 656.06 & & \\
\hline Pridorozhnoye Vostochnoye & 24.55 & 7.82 & & \\
\hline Promezhutochnoye & 24.55 & 7.82 & & \\
\hline Pyakutaskoye & 45.88 & 14.50 & & \\
\hline Pyakutaskoye Vostochnoye & 61.82 & 17.62 & & \\
\hline Pylinskoye & 32.94 & 23.98 & & \\
\hline Pylinskoye Zapadnoye & 24.55 & 7.75 & & \\
\hline Ravenskoye & 36.00 & 13.35 & & \\
\hline Rodnikovoye & 352.28 & 100.40 & & \\
\hline Romanovskoye & 103.86 & 21.91 & & \\
\hline Roslavlskoye & 76.46 & 32.50 & & \\
\hline Rubinovoye & 3.07 & 0.70 & & \\
\hline Ruf'yeganskoye & 4.78 & 1.72 & & \\
\hline Russkinskoye(Tevlin-Konit.) & 71.68 & 21.91 & & \\
\hline Ryamnoye & 6.10 & 2.76 & & \\
\hline Sakhalinskoye Vostochnoye & 60.46 & 17.78 & & \\
\hline Sakhalinskoye (Tyumen) & 90.49 & 22.10 & & \\
\hline Salymskoye Severnny & 163.66 & 46.64 & & \\
\hline Salymskoye & 24.55 & 7.75 & & \\
\hline Salymskoye Vostochnoye & 19.88 & 6.28 & & \\
\hline Salymskoye Zapadnoye & 65.25 & 20.64 & & \\
\hline Salymskoye Central (Srednesalym) & 104.32 & 29.73 & & \\
\hline \multicolumn{5}{|c|}{ Samotlorskoye (Vata, Megion, Poku' Sev., } \\
\hline Mykhpay, Orekhovo Sev.) & $24,660.99$ & $11,879.84$ & $3,161.97$ & \\
\hline Saporkinskoye & 36.91 & 10.52 & 47.20 & 0.85 \\
\hline Sardakovskoye Yuzhnoye & 15.29 & 4.83 & & \\
\hline Savuyskoye & 291.32 & 83.90 & & \\
\hline Saygataskoye & 150.53 & 36.46 & & \\
\hline Shapshinskoye & 124.62 & 35.52 & & \\
\hline Shchuch'yeskoye & 41.42 & 24.11 & & \\
\hline Shirokovskoye & 89.77 & 25.80 & & \\
\hline Soimlorskoye Severnoye & 87.66 & 36.56 & & \\
\hline Sokhtymskoye & 2.00 & 1.00 & & \\
\hline Solkinskoye Zapadnoye & 7.06 & 1.61 & & \\
\hline Sorominskove Severnoye & 2.55 & 0.81 & & \\
\hline Sorominskoye & 5.13 & 1.90 & & \\
\hline Sorominskoye Zapadnoye & 0.51 & 0.16 & & \\
\hline Sortymskoye & 24.55 & 7.77 & & \\
\hline Sorymskoye & 33.08 & 8.27 & & \\
\hline Sovetskoye & $6,050.59$ & $1,579.28$ & & \\
\hline Sredne-Vatlorskoye & 64.22 & 16.12 & & \\
\hline Sredne Khulymskoye & 354.46 & 101.02 & & \\
\hline Sredne-Iterskoye & 24.55 & 7.82 & & \\
\hline Sredne-Shapshinskoye & 24.55 & 7.82 & & \\
\hline Sredneasomkinskoye & 34.15 & 10.81 & & \\
\hline Srednebalykskove & 104.79 & 14.73 & 584.50 & 10.52 \\
\hline Srednechernogorskoye & 22.83 & 8.63 & & \\
\hline
\end{tabular}


Table 22D. Calculated Crude Oil, Natural Gas, and Condensate Recovery by Field, Middle Ob Region, West Siberian Basin (Sorted Alphabetically by Field Name) (Continued)

\begin{tabular}{|c|c|c|c|c|}
\hline Field Name & $\begin{array}{l}\text { Ultimate } \\
\text { Crude Oil } \\
\text { (million } \\
\text { barrels) } \\
\end{array}$ & $\begin{array}{l}\text { Associated- } \\
\text { Disolved Gas } \\
\text { (billion } \\
\text { cubic feet) }\end{array}$ & $\begin{array}{l}\text { Nonassociated } \\
\text { Gas } \\
\text { (billion } \\
\text { cubic feet) } \\
\end{array}$ & $\begin{array}{c}\text { Condensate } \\
\text { (million } \\
\text { barrels) }\end{array}$ \\
\hline Sredneugutskoye & 24.55 & 7.78 & & \\
\hline Strezhevoye Vostochnoye & 3.06 & 0.97 & & \\
\hline Strezhevoye & 28.63 & 7.19 & & \\
\hline Studenoye & 40.28 & 21.71 & & \\
\hline Sugmutskoye & $3,327.14$ & 768.57 & & \\
\hline Surgutskoye Severnoye & 431.28 & 85.18 & $1,137.75$ & 20.48 \\
\hline \multicolumn{5}{|l|}{ Surgutskoye Vostochnoye } \\
\hline (Federovo-Surgut) & 125.68 & 34.08 & & \\
\hline Surgutskoye Yuzhnny(Federovo) & $1,540.86$ & 356.26 & & \\
\hline \multicolumn{5}{|l|}{ Surgutskoye Zapadnoye } \\
\hline (Federovo-Surgut) & 787.05 & 177.33 & & \\
\hline Sutorlinskoye & 42.23 & 12.04 & & \\
\hline Taplorskoye & 3.70 & 1.37 & 175.55 & 3.16 \\
\hline Tarkhovskoye Severnoye & 8.08 & 2.93 & & \\
\hline Tarkhovskoye Yuzhnoye & 2.22 & 0.80 & & \\
\hline Tarkhovskoye Zapadnoye & 5.54 & 2.53 & & \\
\hline Taybinskoye (Lyantor) & & & 178.02 & 3.20 \\
\hline Teplin-Russkinskoye & 230.83 & 85.64 & & \\
\hline Teplovskoye & 867.99 & 185.66 & & \\
\hline Tevlin-Konitlorskoye & 530.15 & 167.95 & & \\
\hline Tevlinskoye & 350.49 & 99.89 & & \\
\hline Tochinskoye & 19.86 & 7.37 & & \\
\hline Tonchinskoye & 24.55 & 7.78 & & \\
\hline Trom-Yeganskoye Severnoye & 9.78 & 3.10 & & \\
\hline Trom-Yeganskoye & 236.21 & 65.14 & & \\
\hline Trom-Yeganskoye Vostochnoye & 12.00 & 3.81 & & \\
\hline Tundrinskoye & 35.42 & 16.15 & & \\
\hline Tutlimskoye (Tutlym) & 33.10 & 9.43 & & \\
\hline Tyanovskoye & $1,237.75$ & 2.00 & & \\
\hline Tyumenskoye & 244.63 & 63.34 & 158.18 & \\
\hline Udachnoye & 24.55 & 7.82 & & \\
\hline Ugutskoye & 184.69 & 48.51 & & \\
\hline Ugutskoye Zapadnoye & 15.68 & 6.47 & & \\
\hline \multicolumn{5}{|l|}{ Uryevskoye(-Potochnoye) } \\
\hline (Pokachev-Ur'yev) & 735.80 & 205.17 & & \\
\hline Ust-Koyukhtaskoye & 24.55 & 7.79 & & \\
\hline Ust-Balykskoye Zapadnoye & 2.55 & 0.81 & & \\
\hline Ust-Balyk-Mamontovoskoye & $2,134.36$ & 454.22 & & \\
\hline Ust-Kotukhtinskoye & 24.55 & 7.76 & & \\
\hline Vachimskoye & 515.79 & 173.57 & & \\
\hline Vadelypskoye & 73.91 & 23.44 & & \\
\hline Vartov-Sovetskoye & 272.70 & 101.17 & & \\
\hline Vartovskoye-Sosinoskoye & $3,001.85$ & $1,079.54$ & & \\
\hline Vat'yeganskoye & $3,987.53$ & $1,087.74$ & & \\
\hline Vat'yeganskoye Severnoye & 29.68 & 8.35 & & \\
\hline Vat'yeganskoye Yuzhnoye & 17.40 & 6.46 & & \\
\hline Vataskoye Severnaya & 24.55 & 7.79 & & \\
\hline Vataskoye & 86.66 & 27.48 & & \\
\hline Vatinskoye & $1,130.17$ & 306.23 & & \\
\hline Verkhne Nadymskoye & 24.55 & 7.79 & & \\
\hline
\end{tabular}


Table 22D. Calculated Crude Oil, Natural Gas, and Condensate Recovery by Field, Middle Ob Region, West Siberian Basin (Sorted Alphabetically by Field Name) (Continued)

\begin{tabular}{|c|c|c|c|c|}
\hline Field Name & $\begin{array}{l}\text { Ultimate } \\
\text { Crude Oil } \\
\text { (million } \\
\text { barrels) }\end{array}$ & $\begin{array}{l}\text { Associated- } \\
\text { Disolved Gas } \\
\text { (billion } \\
\text { cubic feet) }\end{array}$ & $\begin{array}{l}\text { Nonassociated } \\
\text { Gas } \\
\text { (billion } \\
\text { cubic feet) } \\
\end{array}$ & $\begin{array}{l}\text { Condensate } \\
\text { (million } \\
\text { barrels) }\end{array}$ \\
\hline Verkhnesalymskoye & 400.07 & 130.31 & & \\
\hline Verkhneshapshinskoye & 62.34 & 23.13 & & \\
\hline Verkhniy Kazymskoye & 23.28 & 7.40 & & \\
\hline Vershinnoye & 9.94 & 3.35 & & \\
\hline Vladigor Yuzhnoye & 24.55 & 7.82 & & \\
\hline Vyintoy & 94.26 & 27.32 & & \\
\hline Vyintoy Yuzhnoye & 1.53 & 0.49 & & \\
\hline Vyintoy Vostochnoye & 21.41 & 6.81 & & \\
\hline XXVII CPSU Congress & 160.06 & 50.94 & & \\
\hline Yagunskoye Severnoye & 21.92 & 6.98 & & \\
\hline Yagunskoye & 142.73 & 45.45 & & \\
\hline Yagunskoye Yuzhnoye & $1,151.14$ & 320.71 & & \\
\hline Yagunskoye Vostochnoye & 18.94 & 5.82 & & \\
\hline Yamskoye & 2.00 & 1.00 & & \\
\hline Yaunlorskoye & 820.12 & 225.96 & 8.09 & 0.15 \\
\hline Yefremovoskoye & 95.66 & 27.26 & & \\
\hline Yegur'yakhskoye Yuzhnoye & 61.79 & 26.20 & & \\
\hline Yegur'yakhskoye & 20.17 & 7.93 & & \\
\hline Yegur'yakhskoye Severnoye & 2.56 & 1.02 & & \\
\hline Yelovoyeskoye Vostochnoye & 62.70 & 19.96 & & \\
\hline Yermakovoskoye Severnoye & 24.55 & 7.81 & & \\
\hline Yermakovoskoye & 993.86 & 275.74 & & \\
\hline Yershovskoye (Tyumen) & 159.56 & 51.93 & & \\
\hline Yuganskoye & 24.55 & 7.81 & & \\
\hline Yur'yevskoye Severnoye & 474.39 & 155.82 & & \\
\hline Yuzhnoye-1 & 289.91 & 144.11 & & \\
\hline Yuzhnoye-2 & 57.09 & 18.17 & & \\
\hline TOTAL & $98,227.09$ & $33,160.34$ & $6,720.42$ & 61.20 \\
\hline
\end{tabular}

Notes: Altemate field names or combinations in parenthesis.

Source: Energy Information Administration, Office of Oil and Gas. 
Table 23D. Basic Field Information, Unknown Region, West Siberian Basin (Sorted Alphabetically by Field Name)

\begin{tabular}{|c|c|c|c|c|c|}
\hline Field Name & $\begin{array}{c}\text { North } \\
\text { Latitude } \\
\text { (degrees) }\end{array}$ & $\begin{array}{c}\text { East } \\
\text { Latitude } \\
\text { (degrees) }\end{array}$ & $\begin{array}{c}\text { Discovery } \\
\text { Date }\end{array}$ & $\begin{array}{l}\text { Producing } \\
\text { Status } \\
\end{array}$ & $\begin{array}{l}\text { Primary } \\
\text { Product }\end{array}$ \\
\hline Akaytemskoye & & & 1991 & SI & Gas \\
\hline Anomalnoye & & & 1992 & SI & Oil \\
\hline Kulginskoye & & & 1992 & $\mathrm{SI}$ & Oil \\
\hline Maksimkinskoye & & & 1992 & si & Oil \\
\hline Muryaunskoye & & & & SI & Oil \\
\hline Posnokortskoye & & & & SI & Oil \\
\hline Shtomovoye & & & 1992 & Si & Gas \\
\hline Sporishevskoye & & & 1993 & SI & Oll \\
\hline Sredne-Imurskoye & & & 1990 & SI & Oil \\
\hline Triyurtinskoye & & & 1988 & SI & Oil \\
\hline Triyurtinskoye Vostochnoye & & & 1988 & si & Oil \\
\hline Udmurt Yuzhnove & & & 1992 & si & Oil \\
\hline Unlorskoye & & & 1989 & SI & Oil \\
\hline Valyuninskoye Vosstochnoye & & & 1988 & Si & Oil \\
\hline Vankorskoye & & & 1990 & SI & Oil \\
\hline
\end{tabular}

Notes: PP=Producing Primary, PS=Producing Secondary, DV=Developing, Sl=Shut In, ABND=Abandoned. Alternate field names or combined field names in parenthesis.

Source: Energy information Administration, Office of Oil and Gas. 
Table 24D. Calculated Crude Oil, Natural Gas, and Condensate Recovery by Field, Unknown Region, West Siberian Basin (Sorted Alphabetically by Field Name)

\begin{tabular}{lcccc}
\hline & Ultimate & Associated- & Nonassociated & \\
& Crude Oil & Disolved Gas & Gas & Condensate \\
(million & (billion & (billion & (million \\
Field Name & barrels) & cubic feet) & cubic feet) & barrels) \\
\hline
\end{tabular}

Akaytemskoye

Anomalnoye

Kulginskoye

Maksimkinskoye

Muryaunskoye

Posnokort

Shtomovoye

Sporishevskoye

Sredne-Imurskoye

Triyurtinskoye

Triyurtinskoye Vostochnoye

Udmurt Yuzhnoye

Unlorskoye

Valyuninskoye Vosstochnoye

Vankorskoye barrels)

cubic feet)

15.00

$\begin{array}{ll}2.00 & 1.00 \\ 2.00 & 1.00 \\ 2.00 & 1.00 \\ 2.00 & 1.00 \\ 2.00 & 1.00 \\ & \\ 2.00 & 1.00 \\ 2.00 & 1.00 \\ 2.00 & 1.00 \\ 2.00 & 1.00 \\ 2.00 & 1.00 \\ 2.00 & 1.00 \\ 2.00 & 1.00 \\ 2.00 & 1.00\end{array}$

TOTAL

26.00

13.00

30.00

Notes: Alternate field names or combinatic ns in parenthesis.

Source: Energy Information Administration, Office of Oil and Gas. 
Glossary 



\section{Glossary}

API: American Petroleum Institute, a trade association.

API Gravity: Arbitrary scale of measurement for expressing the specific gravity of oil or condensate.

EUR: Estimated Ultimate Recovery. Technical hydrocarbon recovery without current economic, operational, and regulatory limits.

Net/Gross Ratio: Net pay divided by gross pay.

R/P Ratio: Estimated ultimate recovery minus cumulative production divided by current annual production.

Abandonment Pressure: Reservoir pressure at time of abandonment of a gas reservoir.

Area (of West Siberia): Four subdivisions of the basin based on the combination of geographical Regions with common age of reservoir rocks, type of trap, and kind of hydrocarbon produced.

Associated-Dissolved Gas: Natural gas in solution with a liquid oil phase in a reservoir (also called "solution gas").

Basin: An geographic area in which sediments accumulate.

Condensate: Hydrocarbon liquid separated at the surface from natural gas.

Crude Oil: Hydrocarbon occurring as a liquid in the reservoir and remaining a liquid when brought to the surface.

Depletion: Removal of a hydrocarbon from a reservoir.

Developed: Having an installed infrastructure necessary for production.

Discover: Find a reservoir containing hydrocarbons by drilling.

Exploration: Search for reservoirs containing hydrocarbons.

Field: Common area of hydrocarbon production.
Field Size: Sum of estimated ultimate recovery from reservoirs in a field.

Fluid Volume Factor: Factor for the conversion of hydrocarbon volumes from reservoir conditions to surface conditions (Also called Formation Volume Factors).

Geology: The study of the history of the earth as recorded in its rocks; the study of the earth's rocks to locate hydrocarbons.

Gross Pay: Total thickness of a reservoir.

Hydrocarbon: An organic chemical compound of carbon and hydrogen produced in a gaseous or liquid phase.

Improved Recovery: Increasing the hydrocarbon recovery from a reservoir by injection of a substance such as water or gas to displace hydrocarbons from the reservoir or to maintain the reservoir pressure.

Natural Gas: A hydrocarbon occurring in the gaseous phase.

Net Pay: Thickness of the productive portion of the reservoir.

Non-Associated Gas: Hydrocarbon in the gaseous phase in the reservoir and at surface conditions.

Peak Production: Highest production rate in the life of the measured unit (well, field, area, etc.).

Porosity: Void space of the reservoir rock relative to the total volume of the rock.

Possible Reserves: Unproved volume of reserves which analysis of geologic and engineering data suggests are less likely to be recovered than probable reserves.

Primary Recovery: Amount of hydrocarbon recovered without adding energy to the reservoir.

Probable Reserves: Unproved volume of reserves which analysis of geologic and engineering data suggest are more likely than not to be recovered. 
Production Decline: Reduction in producing rate caused by depletion.

Proved Reserves: Quantity of hydrocarhon that can be estimated with reasonable certainty, by analysis of geologic and engineering data, to be commercially recoverable, from a given date, from known reservoirs and under current economic conditions, operating methods, and government regulations.

Province: Large area or region with common characteristics.

Recovery Factor: Estimate of recoverable hydrocarbons relative to the total volume originally in place.

Recovery Efficiency: (See recovery factor).

Region (Of West Siberia): Ten geographical subdivisions of the basin.

Reserves: Recoverable hydrocarbons within limits (proved, probable, or possible).

Reservoir: Subsurface geologic formation containing hydrocarbons.

Reservoir Parameter: Describes the physical characteristics of the rocks and fluids of a reservoir.

Resource: Estimated volume of potentially recoverable hydrocarbons including producing, non-producing, and undiscovered estimated volumes.

Undiscovered: Hydrocarbon volume projected to be discovered in the future. 